\title{
Theater en het performatief spectrum : transities in het contemporaine theater van de Lage Landen
}

Citation for published version (APA):

Havens, H. I. J. W. (2015). Theater en het performatief spectrum : transities in het contemporaine theater van de Lage Landen. [Doctoral Thesis, Maastricht University]. Datawyse / Universitaire Pers Maastricht. https://doi.org/10.26481/dis.20151015hh

Document status and date:

Published: 01/01/2015

DOI:

10.26481/dis.20151015hh

Document Version:

Publisher's PDF, also known as Version of record

\section{Please check the document version of this publication:}

- A submitted manuscript is the version of the article upon submission and before peer-review. There can be important differences between the submitted version and the official published version of record.

People interested in the research are advised to contact the author for the final version of the publication, or visit the DOI to the publisher's website.

- The final author version and the galley proof are versions of the publication after peer review.

- The final published version features the final layout of the paper including the volume, issue and page numbers.

Link to publication

\footnotetext{
General rights rights.

- You may freely distribute the URL identifying the publication in the public portal. please follow below link for the End User Agreement:

www.umlib.nl/taverne-license

Take down policy

If you believe that this document breaches copyright please contact us at:

repository@maastrichtuniversity.nl

providing details and we will investigate your claim.
}

Copyright and moral rights for the publications made accessible in the public portal are retained by the authors and/or other copyright owners and it is a condition of accessing publications that users recognise and abide by the legal requirements associated with these

- Users may download and print one copy of any publication from the public portal for the purpose of private study or research.

- You may not further distribute the material or use it for any profit-making activity or commercial gain

If the publication is distributed under the terms of Article $25 \mathrm{fa}$ of the Dutch Copyright Act, indicated by the "Taverne" license above, 
THEATER

EN HET PERFORMATIEF SPECTRUM 


\section{Colofon}

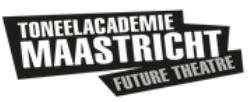

Lectoraat Autonomie \& Openbaarheid in de Kunsten

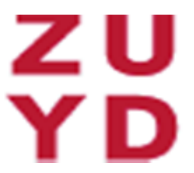

Maastricht University

Druk: Datawyse/Universitaire Pers Maastricht

Ontwerp omslag: Peter Missotten

Foto omslag: Jochem Jurgens.

Op de foto staan Eric Joris (achterzijde) en Marijn Alexander de Jong (voorzijde) in EXPLORER/Prometheus Unchained (2015), het tweede deel van de internettrilogie die theatergezelschap Urland maakt. Voor dit tweede deel werkte Urland samen met kunstenaar/theatermaker Eric Joris, zijn gezelschap CREW uit Brussel en met Productiehuis Rotterdam.

Copyright@ Maart 2015 Henk Havens, Maastricht henk.havens@zuyd.nl 


\title{
THEATER
}

\section{EN HET PERFORMATIEF SPECTRUM}

Transities in het contemporaine theater van de Lage Landen

\author{
PROEFSCHRIFT
}

ter verkrijging van de graad van doctor aan de Universiteit Maastricht, op gezag van de Rector Magnificus, prof. dr. L. L. G. Soete volgens het besluit van het College van Decanen, in het openbaar te verdedigen op donderdag 15 oktober 2015 om 14.00 uur

door

Hendrikus Ignatius Josephus Waltherus Havens 


\section{Promotor}

Prof. dr. M.J.H. Meijer

\section{Copromotor}

Dr. P.F. Peters

\section{Beoordelingscommissie}

Prof. dr. R. van de Vall (voorzitter)

Dr. M.J. Kattenbelt (Universiteit Utrecht)

Prof. dr. K. Röttger (Universiteit van Amsterdam)

Prof. dr. K. Vanhaesebrouck (Université Libre de Bruxelles)

Prof. dr. K. Vanhoutte (Universiteit van Antwerpen) 


\title{
Inhoudsopgave
}

\author{
Inhoudsopgave
}

Voorwoord

Hoofdstuk 1 Inleiding 17

1.1 Openingsbeeld 2007 - 2014

After Dubrovka - performance en wereldwijd activisme 17

$\begin{array}{ll}\text { O_Rex - theater en immersieve media } & 19\end{array}$

Red Hot Chili Peppers, Beyoncé, Björk - pop en kunst 20

Het Zuidelijk Toneel - theater en urban space 21

Interculturaliteit, intermedialiteit, internationaliteit 22

1.2 Theater en culturele dynamiek $\quad 24$

Culturele dynamiek 25

Contemporaine theaterinstituties 29

1.3 Positionering van het onderzoek: de praktijk en de theaterwetenschap 33

Richard Schechner 34

Lehmanns Postdramatisches Theater $\quad 35$

Het discours na Lehmann 38

Hoofdstuk 2 Theoretisch kader 43

2.1 Inleiding $\quad 43$

2.2 Conceptuele analyse $\quad 45$

Drama en tekst 45

Drama, theater en theatraliteit 46

Performance, performatief en performativiteit $\quad 49$

2.3 Theorie en methode: het denken in netwerken 52

Even-Zohars polysysteemtheorie $\quad 52$

Deleuzes Rizoom 62

Latours Actor-Network Theory $\quad 65$

2.4 Praktijk als onderzoekscontext: Practice as Research 69 
Hoofdstuk 3 Theatergezelschap in transitie $\quad 75$

$\begin{array}{ll}3.1 & 75\end{array}$

3.2 Toneelhuis Antwerpen $\quad 77$

Verkenning van de grens tussen theater en technologie

Huis van het verschil $\quad 80$

Artistieke emancipatie van theatertechnici 85

Nieuwe theatertaal: zintuigen openzetten 87

Investeren in technologie, onderzoek en internationale samenwerking 92

Strategische inzet van gebouw en mensen 96

$\begin{array}{ll}\text { Doorstroming } & 100\end{array}$

3.3 Toneelhuis Antwerpen en het postdramatisch discours 103

$\begin{array}{ll}\text { Repertoire } & 103\end{array}$

Gezelschap 106

$\begin{array}{ll}\text { Theaterlandschap } & 108\end{array}$

3.4 Conclusies 110

Hoofdstuk 4 Podium in transitie 113

4.1 Inleiding 113

4.2 De Verkadefabriek in 's-Hertogenbosch 115

Hergebruik van industrieel erfgoed 115

Gebouw 119

Café-restaurant 121

Theaterzalen 122

Repetitielokalen 124

$\begin{array}{lr}\text { Filmzalen } & 125\end{array}$

Woord 126

Festivals 128

$\begin{array}{ll}\text { Bedrijfsvoering } & 131\end{array}$

4.3 De Verkadefabriek als mediator $\quad 134$

$\begin{array}{ll}\text { Kruispunten van het inter } & 135\end{array}$

$\begin{array}{ll}\text { Transportation en translation } & 137\end{array}$

$\begin{array}{ll}\text { Podiumlandschap } & 138\end{array}$

$\begin{array}{lll}4.4 & \text { Conclusies } & 143\end{array}$

Hoofdstuk 5 Theateropleiding in transitie $\quad 147$

$\begin{array}{lll}5.1 & \text { Inleiding } & 147\end{array}$

5.2 Toneelacademie Maastricht 149

Differentiatie van het theateronderwijs: intermedialiteit en technologie $\quad 150$

Onderzoek en kunstpraktijk: doing-thinking in schakelmomenten 158 
Interculturele transities: '....one way or another, we are all migrants'. 163

$\begin{array}{ll}\text { Internationale oriëntatie } & 170\end{array}$

5.3 De Toneelacademie en de veranderende praktijk van het theateronderwijs 175 Van acteur en regisseur naar theatermaker en performer 175

De onderscheidende kleur van Maastricht 181

5.4 Conclusies 186

Hoofdstuk 6 Theaterbeleid in transitie $\quad 189$

6.1 Inleiding 189

6.2 Het Nederlandse theaterbeleidsdiscours 192

Schoonheid, welzijn, kwaliteit en cultureel ondernemerschap 192

Kernbegrippen in richtinggevende documenten 1945 - 2014

6.3 Het theaterbeleidsdiscours, een analyse in verhaallijnen 215

Verhalen van goede en slechte kunst 216

De driehoek overheid - kunst - samenleving 220

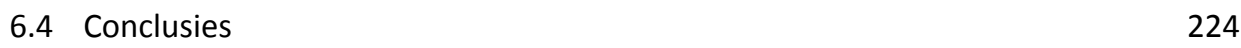

$\begin{array}{lll}\text { Hoofdstuk } 7 & \text { Conclusies } & 227\end{array}$

Theater: crisis of herpositionering? $\quad 227$

$\begin{array}{ll}\text { Practice based research } & 227\end{array}$

De opbrengst van de casestudies $\quad 228$

Voorbij Lehmanns theateresthetiek 230

Discussie en aanbevelingen $\quad 234$

De rol van kunst en het performatief spectrum 238

Referenties en literatuur $\quad 243$

Primaire bronnen $\quad 243$

Interviews $\quad 246$

$\begin{array}{lr}\text { Literatuur } & 247\end{array}$

$\begin{array}{ll}\text { Summary } & 261\end{array}$

$\begin{array}{ll}\text { Valorisatie-addendum } & 267\end{array}$

$\begin{array}{ll}\text { Dankwoord } & 271\end{array}$

$\begin{array}{ll}\text { Curriculum vitae } & 273\end{array}$ 



\section{Voorwoord}

'De Japanse filosoof Nishida gebruikt een mooi beeld voor het moderne denken: het is als een schipbreukeling die op open zee het vlot in elkaar zet waarmee hij zichzelf moet redden. Denken is vanaf nu: nattigheid voelen' (Jans, 2006a, p.7). ${ }^{1}$

Theater Bellevue in Amsterdam, juni 2008. Het maximale aantal van vijftig toeschouwers zit bij de voorstelling WeerSlechtWeer van Toneelhuis Antwerpen op houten bankjes rond een met lood beklede put in de vorm van een omgekeerde piramide. ${ }^{2}$ De afgeplatte punt van de piramide vormt een klein vierkant op de vloer. Samen met de 48 anderen kijken mijn zoon en ik naar beneden. Er staat een laag water op het vierkant van de bodem. Twee in overalls gestoken jongemannen liggen, zitten, staan en bewegen in het laagje water. Een groot deel van de voorstelling staan ze eveneens bloot aan kunstmatige regenbuien door een hightech aangestuurde regenmachine. De tekst is een bewerking van The Waste Land, het gedicht van T.S. Eliot uit 1922. De stemmen van de acteurs zijn elektronisch versterkt, ze spreken door een bekabelde microfoon, althans, die indruk wekken ze. Later lijkt de microfoon niet echt te werken, omdat hij regelmatig met veel geraas in het water valt. De acteurs suggereren echter dat hij wel werkt. Zo wordt een spel gespeeld met echtheid en nietechtheid van gemediatiseerde stemmen, met het wel of niet live uitspreken van de tekst. In feite kan het publiek teksten die zonder microfoon worden uitgesproken onder deze omstandigheden, niet echt verstaan. Geconditioneerd als wij allen zijn, wennen we snel aan de filmische perfectie van het geluid, inclusief zuchtjes en gemompel, ook als we van dichtbij zien dat het onmogelijk is om dat live ook echt te horen. De voorstelling is een mediakritiek op de vrijwel door iedereen voor waar

\footnotetext{
${ }^{1}$ Erwin Jans specificeert niet waar de tekst van Nishida vandaan komt.

2 WeerSlechtWeer (2007), geproduceerd door Toneelhuis Antwerpen. Concept en regie van Peter Missotten, gespeeld door Teun Luijkx en Joost Steltenpool. De voorstelling werd geselecteerd voor het Holland Festival van juni 2008.
} 
aangenomen realiteit van de meeste filmindustriële producten; een gehoorde stem is een echte stem, een waargenomen beeld is een echt beeld. Regisseur Peter Missotten wijst ons erop dat we ons goed moeten realiseren dat technologie veel mogelijk maakt, maar ons ook vaak een rad voor de ogen draait. Hier is sprake van een intermediale werkwijze, waarbij het samengaan van het idioom van theater, film, performance, beeldende kunst, literatuur en muziek een nieuwe theatertaal oplevert. Het gaat om een gemanipuleerde en gemediatiseerde manier van verhalen vertellen. In WeerSlechtWeer werken associaties, onder andere met filmische beelden die we ons herinneren van eerdere verbeeldingen van de eindtijd. Als een van de acteurs in alle rust in het water ligt en zijn haren op de kalme stroom golven, dan dringen zich beelden op uit Tarkovski's filmische meesterwerk Stalker, beelden van stilstaand ondiep water met hier en daar een restje van een voorbije beschaving. De mannen in het water vormen bijna letterlijke beeldcitaten uit de film.

Dit is een voorstelling zonder plot, vol associatieve betekenissen, meer verwijzend naar filmervaringen en naar de beleving van installaties van beeldende kunst dan naar literaire toneelwerken. Is dit nog theater of moeten we het anders noemen? Is dit een uitzondering of inmiddels gemeengoed? Deze voorstelling werd gemaakt onder de vleugels van een groot Vlaams gesubsidieerd gezelschap en geprogrammeerd door het in gevestigde artistieke kringen hogelijk gewaardeerde Holland Festival. Uiteindelijk heeft slechts een kleine publieksgroep deze artistieke exercitie op de grens van theater, performance, film en audio-onderzoek kunnen bezoeken. De voorstelling werd steeds gespeeld voor maximaal vijftig bezoekers en is een beperkt aantal keren uitgevoerd.

Decennialang wordt er al gesproken over theater, als zou het aan puurheid en aan belang inboeten. Tegelijkertijd lijkt belangstelling voor het theatrale en voor het aanpalende domein van het performatieve juist toe te nemen; het lijkt alsof alles en iedereen voortdurend op een of ander podium staat, op een scherm verschijnt, toeschouwer is of alle drie tegelijk.

Dit onderzoek startte in de loop van 2007, gevoed door een fascinatie voor het discours rond de recente vermeende crisis van het theater. Mijn hypothese is dat het theater de laatste decennia ingrijpende veranderingen ondergaat en dat deze transformaties onderdeel zijn van een culturele dynamiek die grofweg te beschrijven is als een complex samenspel van technologische, interculturele en internationale ontwikkelingen. De leidende vraag in dit onderzoek is hoe verschillende blikrichtingen, die van het theater in crisis aan de ene kant en die van een explosief groeiend spectrum van performatieve uitingen aan de andere, zich tot elkaar verhouden. Hoe ziet de wisselwerking tussen het contemporaine theater en culturele dynamiek eruit? 
Aan de ene kant wordt al langer geconstateerd dat het Nederlandse gesubsidieerde theater steeds minder publieke betekenis heeft. Het verloor daardoor voor het geëngageerde segment van het publiek een groot deel van zijn legitimiteit voor overheidssubsidie. Aan de andere kant werd het Nederlandse en Vlaamse theater door theatermakers, kunstcritici en wetenschappers alom geprezen om zijn vernieuwende kwaliteiten. In nationale en internationale vakkringen werd en wordt het vakmatige en inhoudelijke niveau hoog aangeslagen. Tegelijkertijd ontstonden in de brede culturele context van de theatersector vele nieuwe podia, nieuwe productiemethoden en nieuw publiek voor andere performatieve uitingen dan die van het gevestigde theater. Is dit alles samen, de gefragmenteerde artistieke productie en de 'verhuizing' van het grote publiek naar diverse soms moeilijk te classificeren andere performatieve arena's, een theatercrisis te noemen of toch niet?

Als de theatersector de afgelopen decennia weinig publiek genereerde, zou er iets aan de hand kunnen zijn met het publiek, met de theatersector zelf of met allebei. In het centrum van de gevestigde theatersector vond men over het algemeen dat er iets mis was met het publiek: dat zou geen oog hebben voor al het moois van hoge kwaliteit dat het Nederlandse en Vlaamse theater te bieden had; er werd zelfs gesproken van een gemis aan beschaving. De standaardoplossing van het gevestigde theater is steeds geweest te trachten meer begrip te kweken of terug te winnen voor de 'essentiële waarden' van kwaliteitstheater, door bijvoorbeeld meer canonieke kunsteducatie of marketing met als doel meer publiek naar het gevestigde gesubsidieerde theater te krijgen. Het grote publiek keerde zich desondanks al sinds de jaren zeventig voor een deel af van het canonieke segment van de theatersector en zocht zijn heil bij de televisie, de film, de musical, bij festivals, dance events en andere cultuurvormen. Deze vormen leiden in sommige gevallen tot volledig nieuwe en geaccepteerde praktijken naast de gevestigde traditionele. In andere gevallen dagen deze opkomende kunst- en cultuuruitingen de status quo van het gevestigde theater uit.

In Nederland wordt vanaf 2012 voor het eerst sinds de Tweede Wereldoorlog fors bezuinigd op cultuursubsidies. Het traditionele zowel als het experimentele theater in Nederland staat in het begin van de 21e eeuw onder druk, de publieke belangstelling voor traditionele podiumkunsten blijft geleidelijk afnemen. Wijst deze afnemende impact van het reguliere theaterrepertoire op de afnemende betekenis van het theatrale, op de teloorgang van een tweeëneenhalfduizend jaar oude theatertraditie en daarmee op het verlies van het culturele gewicht van het theater? Is er sprake van een diepzwart scenario van verval van het theater of zou er ook iets anders aan de hand kunnen zijn?

De afgelopen jaren heb ik me afgevraagd of er ook met andere ogen naar deze ontwikkelingen gekeken zou kunnen worden. Zijn deze transformatieprocessen 
wellicht te beschouwen als symptomen van iets anders, van iets wat groter is dan een crisis in een specifieke culturele sector? Is het mogelijk om anders dan in doemtermen de ontologie van het theater te duiden? Om met een ander, minder cultuurpessimistisch perspectief naar de gehele gesubsidieerde en ongesubsidieerde theaterinfrastructuur te kijken? Deze vragen liggen ten grondslag aan deze studie.

Er wordt vandaag de dag nog steeds belangwekkend theater gemaakt in vele vormen, dat zal niemand betwijfelen. Wel is zichtbaar dat het traditionele theater anders wordt gemaakt en wordt bekeken dan voorheen en dat er veel performatieve uitingen zijn bijgekomen. De vraag is hoe dat komt en wat dat betekent. De meningen over de aard van deze veranderingen zijn sterk verdeeld. Sommigen spreken over een bedreiging van de beschaving door de veronderstelde teloorgang van een eeuwenoude traditionele cultuur, anderen zien slechts verschuivingen en veranderingen als een organisch transitieproces waar ook het bestaande theater zich niet aan kan onttrekken. Hoe dan ook kunnen we ons afvragen of veel hedendaagse veranderingen in en rond het theater te maken hebben met complexe cultureel dynamische processen, die in mijn ogen gekenmerkt worden door technologische ontwikkelingen, door migratieprocessen en door de globalisering van de culturele industrie. Mijn veronderstelling is dat niets ontsnapt aan dit proces waarin de samenleving onder invloed van deze culturele en maatschappelijke ontwikkelingen in een stroomversnelling aan het veranderen is. Het theater verandert daarin mee.

Het Nederlandse theaterbestel is sinds 1945 gestoeld op vier grootheden: toneelgezelschappen, toneelpodia, theateropleidingen en een theaterbeleid, als onderdeel van een breder landelijk cultuurbeleid. Door dit samenspel zou ongeacht status en afkomst de gehele bevolking gebildet worden, door onder andere kennis te nemen van het westers toneelrepertoire, als onderdeel van een culturele verheffingsstrategie. ${ }^{3}$ Dit theaterbestel bleef de afgelopen zeventig jaar min of meer intact, terwijl de maatschappelijke en culturele context sterk veranderde. Zou het kunnen zijn dat het contemporaine theater tegenwoordig beter te begrijpen is als deel van een complex netwerk van historische en nieuwe ensceneringsvarianten dan door het te blijven zien als een op zichzelf staande hiërarchisch geordende verzameling van canonieke toneelteksten, erkende meesterwerken, representatieve theatervoorstellingen, specifieke werkwijzen en gevestigde podia voor erkende theaterkunst?

We leven al een tijdje in een netwerksamenleving, beweerde de Spaanse socioloog Manuel Castells in de jaren negentig van de vorige eeuw. Hij noemt onze tijd:

\footnotetext{
${ }^{3}$ Hier kom ik op terug in Hoofdstuk 6, waarin het Nederlandse cultuurbeleid centraal staat.
} 
"... a historical period characterized by widespread de-structuring of organizations, delegitimizing of institutions, fading away of major social movements, and ephemeral cultural expressions" (Castells, 1996, p.3).

Door voortschrijdende informatietechnologie en door wereldwijde mobiliteit is verbondenheid in netwerken voor iedereen nagenoeg onontkoombaar geworden, schrijft hij in The Information Age: Economy, Society and Culture (1996/1998). In de vernetwerkte samenleving heeft het theater als ensceneringsmethode in de loop van de twintigste eeuw te maken gekregen met buren als film, televisie en massaculturele evenementen, waarmee steeds nieuwe verbanden werden aangegaan. Het theater staat daardoor minder dan voorheen in het centrum van de Nederlandse culturele orde.

In het lopende cultuurdebat wordt de canonieke theatertraditie regelmatig in zwart-wittermen afgezet tegen een stroom aan cultuurvernieuwingen. De Britse cultuur- en theaterwetenschapper Raymond Williams hanteert in Marxism and Literature (1977) een terminologie om genuanceerder met dit soort verschuivingen om te gaan. Hij neemt afstand van het idee dat een cultuur altijd een statisch coherent systeem is en bestrijdt dat zo'n cultuur als geheel in transitie zou kunnen zijn van het ene cultuursysteem naar het andere, dus bijvoorbeeld van een archaïsche, vaak ouderwets genoemde traditie naar een vernieuwende en daardoor vaak als beter beschouwde, eigentijdse variant. Daarvoor in de plaats spreekt hij over 'interne dynamische relaties' van actuele culturele processen. Hij classificeert die met de termen dominant, residual en emergent (dominante, rest- en opkomende categorieën). Culturele ontwikkelingen doorlopen diverse stadia alvorens ze al dan niet worden geïncorporeerd in heersende culturele patronen. Cultuur die zich als residual verhoudt tot de actuele dominante cultuur, devalueert volgens Williams niet per definitie tot archaïsch in de zin van eigenlijk al definitief behorend tot het verleden en minderwaardig. Zij is als residual iets dat weliswaar in het verleden gevormd is maar dat nog steeds actief is in actuele culturele processen (Williams, 1977, p. 122). Cultuurvormen die Williams emergent noemt ten opzichte van de gevestigde cultuur, staan op twee specifieke manieren in verhouding tot die dominante cultuur. Niet alleen kwalificeert emergent vaak nieuwe betekenissen en waarden naast de dominante cultuur, maar tevens slaat de term op substantieel kritische alternatieven voor het bestaande. Nieuwe ervaringen die niet meteen onder te brengen zijn in gevestigde categorieën, bevorderen gaandeweg de geleidelijke acceptatie van nieuwe of alternatieve culturele verschijningsvormen (Williams, 1977, p. 123).

Een van de veronderstellingen bij de opzet van dit onderzoek is dat we wellicht naar de verhouding tussen de canonieke theatertraditie en de huidige contextuele culturele dynamiek kunnen kijken als naar een gesprek met meerdere 
gesprekspartners. We kunnen ons, in Williams' woorden, afvragen of het residu van de theatercanon als het ware in gesprek is met zowel de cultureel dominante theaterinstituties als met opkomende intermediale, interculturele en internationale culturele sectoren.

De opzet van dit boek is als volgt. Ik gaf al aan dat dit onderzoek startte vanuit mijn fascinatie voor de soms brisante relatie tussen een vermeende theatercrisis en een explosief groeiende sector van performancepraktijken. In het inleidende eerste hoofdstuk wil ik aan de hand van enkele praktijkvoorbeelden een openingsbeeld voor deze studie schetsen: wat kunnen we aantreffen in de hedendaagse theater- en performancepraktijk? In dit hoofdstuk wordt vervolgens de centrale onderzoeksvraag geformuleerd en specificeer ik de onderzoekstermen culturele dynamiek en theaterinstituties. Ik besteed aandacht aan de positionering van mijn onderzoek binnen het kennisdomein van de theaterwetenschap en beschrijf waarom deze studie opgevat kan worden als een bijdrage aan het discours rond het postdramatische theater - een term gemunt door Hans-Thies Lehmann in diens baanbrekende studie, Postdramatisches Theater (1999) - en centrale elementen uit het discours na Lehmann. In hoofdstuk 2 schets ik een theoretisch kader. In de eerste plaats worden in een conceptuele analyse de voor deze studie belangrijkste centrale begrippen als theater, drama en tekst, performance, performativiteit en intermedialiteit behandeld. In de tweede plaats schenk ik aandacht aan de theorieën en methodes van een drietal netwerkdenkers. Ik heb met behulp van de begrippenapparaten van Itamar Even-Zohar (1939), Gilles Deleuze (1925 - 1995) en Bruno Latour (1947), geprobeerd om de positie van het contemporaine theater te analyseren in relatie tot contextuele culturele netwerken. Tenslotte besteed ik in dit hoofdstuk aandacht aan de kunstenpraktijk als onderzoekscontext en aan de specifieke positie die ik bij het uitvoeren van mijn onderzoek innam, tegelijkertijd werkend als onderzoeker en als dramaturgiedocent aan een theateropleiding (reflective practitioner). Ik behandel de methodologische implicaties van een aanpak die vanuit Groot Brittannië bekend aan het worden is als practice as research. Ik beroep me daarbij op Robin Nelsons recente publicatie Practice as Research in the Arts. Principles, Protocols, Pedagogies, Resistances (Nelson, 2013).

Om de wisselwerking tussen het contemporaine theater en de cultureel dynamische context te onderzoeken heb ik vier casestudies of 'diepteboringen' uitgevoerd in de hedendaagse theaterpraktijk. In de hoofdstukken 3, 4, 5, en 6 komen de resultaten van deze exemplarische gevalstudies naar vier institutionele pijlers van het theatersysteem aan de orde: gezelschap, podium, opleiding en overheidsbeleid. Voor het bestuderen van een gevestigd theaterbedrijf vormde het grootste gesubsidieerde Vlaamse gezelschap het Toneelhuis in Antwerpen het studieobject. De structurele ingrepen door de leider van dat gezelschap, Guy Cassiers, bij het opnieuw 
vormgeven van het gezelschap, tonen een nieuwe interpretatie van het begrip theatergezelschap, anders dan die gebaseerd op het traditionele toneelensemble. Als podiuminstitutie was de Verkadefabriek in 's-Hertogenbosch object van studie. De snel gegroeide rol van dat podium in de stad 's-Hertogenbosch en verre omgeving toont het groeiende sociaal-culturele belang van wat podia vermogen te zijn. In de sector van het hoger theateronderwijs heb ik studie gemaakt van de Toneelacademie Maastricht. De theateropleiding poogt zich als een van de gespecialiseerde opleidingen voor professionele theatermakers qualitate qua te verhouden tot de wisselwerking tussen dominante, residuale en opkomende performatieve praktijken. Om de relatie van recent Nederlandse theaterbeleid met culturele dynamiek te duiden heb ik hoofdzakelijk brondocumenten uit de periode 1945 - 2014 bestudeerd, van Het grijze boekje (1946) tot en met de koers wijzigende nota's uit de jaren 2010 - 2014. Uit deze documenten blijkt dat het discours rond het landelijke cultuurbeleid hoofdzakelijk georganiseerd is op basis van hiërarchisch en disciplinegeordende subsidieprocedures. Het toont de frictie tussen de rolopvatting van de Nederlandse overheid en haar belangrijkste adviescollege de Raad voor Cultuur, aan de ene kant en een hedendaagse, cultureel dynamische netwerksamenleving aan de andere kant.

Tenslotte formuleer ik in hoofdstuk 7 mijn conclusies over de resultaten van de vier diepteboringen naar theatertransformaties in het contemporaine theater en de relaties van deze transformaties met contextuele culturele dynamiek. Mijn casestudies laten tevens een vergelijking toe tussen het theaterlandschap dat Hans-Thies Lehmann in 1999 beschreef en de huidige situatie. Ik bespreek hoe de onderzoeksresultaten zich verhouden tot die studie van Lehmann uit 1999 en tot het discours na Lehmann. 



\title{
Hoofdstuk 1 Inleiding
}

\author{
"Watching what the twentieth century playwright and director Bertolt Brecht \\ called the apparatus of the stage from a distance, one in which things \\ mechanically go up and down in the fly space of a theatre or rotate on a turntable \\ may be easy enough, but what are we to say about the Gordian territories that \\ jumble together performers and spectators, spectators and scenographic \\ environments, computers and actors, theatre and urban space, architecture and \\ machine, the research lab and the temporary festival?" (Salter, 2010, p. xxxii).
}

\section{$1.1 \quad$ Openingsbeeld $2007-2014$}

In dit eerste hoofdstuk staat de opzet van mijn onderzoek centraal en de positionering daarvan binnen de theaterwetenschap. Het onderzoek is descriptief en exploratief van aard en het mag opgevat worden als een vervolgstudie naar de effecten van Lehmanns postulaat van het Postdramatisches Theater (1999) en op belangrijke noties uit het discours na Lehmann tot 2015.

Lehmanns postdramatisch panorama, de verzameling uiteenlopende theater- en performancepraktijken waarin het tekstdrama niet langer als organiserend principe gehanteerd wordt, lijkt na vijftien jaar gemeengoed geworden in het theater (Swyzen \& Vanhoutte, 2011, p. 6 en p. 285). Daarnaast lijkt het discours rond centrale concepten in Lehmanns studie, als performance en performativiteit, intermedialiteit en non-hiërarchie, en rond de verhouding tussen lokale cultuur en globaliserende cultuurindustrie alleen maar complexer te worden. Om een beeld te schetsen van het hedendaagse 'theater'-landschap, geef ik hier vier voorbeelden van praktijken die representatief zijn voor de breedte van het huidige performatieve veld. Vervolgens formuleer ik de centrale onderzoeksvraag van deze studie en expliciteer ik de voornaamste onderzoekstermen. In de tweede helft van dit hoofdstuk besteed ik aandacht aan de positionering van mijn onderzoek. Ik zet uiteen waarom het gerekend kan worden tot het kennisdomein van de theaterwetenschap.

\section{After Dubrovka - performance en wereldwijd activisme}

In oktober 2007 zag ik, in het kader van een uitwisseling tussen het Department of Contemporary Arts van Manchester Metropolitan University en de Toneelacademie Maastricht, samen met een aantal collega's een voorstelling in Manchester, getiteld 
After Dubrovka. ${ }^{4}$ Het was eigenlijk geen voorstelling maar meer een theatrale installatie. De theaterzaal was bekabeld en uitgerust met speakers en microfoons en tijdens de duur van de installatie waren er geen performers te zien; er trad niemand op. Het publiek werd voor iedere 'voorstelling' in groepen verdeeld. Eén groep werd naar een kleine theaterzaal geleid en gesommeerd om op het podium te gaan staan. leder koos positie onder een van de los neerhangende, kleine luidsprekers. Wat we op het podium zachtjes door de luidsprekers hoorden, ging over het gijzelingsdrama dat in 2002 in het Moskouse Dubrovka Theater had plaatsgevonden. Veertig gewapende Tsjetsjeense militanten gijzelden destijds tijdens een opvoering van de musical Nord Ost een grote groep toeschouwers en performers. De gijzeling duurde bijna tweeënhalve dag. Bij de bevrijding door Russische troepen, waarbij onzorgvuldig gebruik werd gemaakt van een verdovend gifgas, vielen 129 slachtoffers.

Als publiek op het podium hoorden we individueel op ons gerichte stemmen die spraken over de beleving van de gijzelingssituatie als lid van het publiek in het theater, of als getuige van deze gebeurtenis thuis voor de televisie. De installatie was theater en tegelijkertijd geen theater. Het was een theatrale gebeurtenis in een theatergebouw, verwijzend naar een gebeurtenis die werkelijk had plaatsgevonden in een ander werkelijk bestaand theatergebouw. Het leek wel een herinneringsritueel. Terwijl ik op het podium stond, verdeelde een andere groep van het publiek zich over de publieksruimte. Deze mensen bekeken vervolgens ons, hun luisterende medepublieksleden op het podium. Na verloop van enige tijd vertrok het publiek en namen wij, de podiumgroep, hun plaats op de theaterstoelen in, terwijl een nieuwe publieksgroep op het podium ging staan. Vanuit de theaterzaal bekeek ik nu zelf het statische schouwspel op het podium zoals ik zojuist zelf bekeken was. Zo rouleerde het publiek steeds in groepen.

In de discussie na de voorstelling ging het vooral om het volgende. Wat heeft de culturele wereld te bieden als gesprekspartner of contrapunt voor de snelle en goed geregisseerde globale communicatiestrategieën van internationaal opererende politieke en religieuze, al dan niet terroristische, organisaties? We zijn gewend om alle soorten van informatie uit te wisselen, vooral met behulp van taal. Wat voor materiaal en gereedschap dienen we vandaag de dag in te zetten om te communiceren? In luttele seconden zetten extreme varianten van die organisaties dreigementen, videobeelden, boodschappen voor wereldleiders en namen van gemeenschappen die men wil treffen op internet en hebben zo een impact die nog nooit op dezelfde schaal vertoond is.

\footnotetext{
${ }^{4}$ After Dubrovka (2007), een theaterinstallatie door Neil Mackenzie and Mole Wetherell, samen met sound designer Spencer Marsden en geproduceerd door het Nuffield Theatre, Lancaster, UK. De installatie werd medegefinancierd door de Arts Council England, Prema Arts Centre, Manchester Metropolitan University en het Grand Theatre Lancaster.
} 
Dit voorbeeld toont dat de invloed van internationale nieuwsmedia in combinatie met de stand van de technologie zich doet voelen. De democratisering van de massamedia is compleet. Vanuit nagenoeg elk gebied op aarde is vrijwel onmiddellijk te communiceren met de rest van de wereld. In woord en beeld. Een globaliserende culturele industrie zorgt ervoor dat steeds meer gebieden gaan behoren tot de door Peter Sloterdijk benoemde "Weltinnenraum des Kapitals" om zo deelgenoot te worden van wereldwijd gekende codesystemen en informatiestromen (Sloterdijk, 2006).

\section{O_Rex - theater en immersieve media}

Het Vlaamse gezelschap CREW speelde op vrijdag 25 januari 2008 de voorstelling O_Rex. ${ }^{5}$ Het zou zo dadelijk beginnen, ik wachtte samen met de rest van het publiek. In de foyer van De Brakke Grond in Amsterdam werden vier personen, mannen, voorgesteld aan het wachtende publiek. Het waren vrijwilligers en één van hen zou vanavond de hoofdrol gaan spelen in het stuk. Het publiek stemde in een paar rondes en de winnaar werd met zachte hand meegenomen door medewerkers van CREW. De uitverkorene werd vanavond Oedipus.

Wij, de toeschouwers, lopen nu de zaal in. Een enorm, ingenieus geconstrueerd pijpenstelsel steekt vanuit een soort hutje op de speelvloer in een diagonaal dwars door de zaal naar een punt ver boven de achterste rijen van de publiekstribune. Aan het uiteinde van verschillende vertakkingen van het pijpenstelsel zitten hoorns. Ze lijken op ouderwetse geluidshoorns, zoals op de afbeelding van His Masters Voice. Links van het podium is een enorme tafel zichtbaar vol met technologische regelapparatuur. Er zitten een paar mensen achter, in het zwart gekleed. Op de achtergrond hangt hoog boven de speelvloer een groot beeldscherm. Rond het speelvlak zijn loopvlakken, een soort verhoogde vlonders. Er zijn rijdende robotjes. Sommige daarvan zijn laptops waarop bewegende beelden te zien zijn, andere zijn hoorns, van dezelfde soort als die boven ons hoofd, alleen veel kleiner. Uit die rijdende hoorntjes komen stemmen, als waren het personages. De robots draaien hun hoorntjes in de richting van sprekers, alsof ze hun hoofd draaien. Op het grote beeldscherm zien we de hoofdrolspeler, de vrijwilliger, die wordt gefilmd op een andere plaats dan de publieksruimte. We zien dat hij een grote integraalhelm op krijgt; we kunnen veronderstellen dat hij nog slechts een virtuele werkelijkheid waarneemt.

\footnotetext{
${ }^{5} O_{-}$Rex , een theatervoorstelling uit 2008 van het Vlaamse gezelschap CREW, is gebaseerd op de metafoor van de mythologische figuur Oedipus. De voorstelling speelt met de gedachte dat de moderne mens met al zijn communicatiemiddelen nog amper een eenduidig standpunt kan innemen of zijn eigen ogen kan vertrouwen. Het gebrek aan een centraal perspectief op de wereld wordt geënsceneerd door het toepassen van immersieve technologie. Er ontstaan twee voorstellingen die geen van beiden volledig zicht bieden op wat zich allemaal afspeelt. Retrieved August 19, 2014, from http://www.crewonline.org/art/projects.
} 
Die door de hoofdpersoon waargenomen werkelijkheid zien wij als toeschouwers geprojecteerd op het grote scherm in de zaal, afgewisseld met beelden van het hoofdrolpersonage. Als toeschouwer zien we dus op hetzelfde moment diverse 'werkelijkheden'.

Op een bepaald moment, na een inleidende monoloog waarin Oedipus toegesproken wordt, komt de hoofdrolspeler de zaal binnen. Hij loopt achter een rolstoel die volgestopt is met apparatuur, inclusief een camera. Een replica van die rolstoel staat leeg midden op de speelvloer. Die replica wordt regelmatig en voor ons volledig zichtbaar gefilmd en gebruikt door een tweede speler, de verteller. Later wordt duidelijk dat de virtuele beelden voor de hoofdrolspeler bewerkt worden. De hoofdrolspeler wordt begeleid door een speler/technicus, een vrouw in het zwart, die vooral zorg draagt voor de apparatuur. Ze beweegt zo onopvallend mogelijk mee met de hoofdpersoon. Deze technicus lijkt de hoofdrolspeler ook zachtjes te instrueren en wellicht staat ze tevens in contact met een centrale regie.

Het hele idee van de voorstelling bestaat eruit dat wat we zien en meemaken een stadium is in een onderzoeksproces van CREW naar mogelijkheden om narratieve niveaus van de live performance en van de virtuele werkelijkheden vloeiend te laten samengaan. Op die manier zou er in de nabije toekomst een immersieve podiumkunstenvariant kunnen ontstaan, waarbij de media film, streaming video en live performance opgaan in één nieuwe vorm van een meerlagige narrativiteit. Dit voorbeeld toont dat het voorstelbaar is dat op den duur het onderscheid tussen de verschillende media steeds meer zal vervagen en het niet meer relevant zal zijn welk medium wat ontleent aan welk ander medium. In O_Rex speelt CREW een spel op basis van het Oedipusverhaal. Het doet dienst als metafoor voor wat wij ons onder invloed van alomtegenwoordige media voortdurend afvragen: wie ziet en wie is blind?

\section{Red Hot Chili Peppers, Beyoncé, Björk - pop en kunst}

In de globaliserende cultuurindustrie wordt volop gebruikgemaakt van kunsttaal die is ontwikkeld in de gevestigde kunstwereld. De Amerikaanse band The Red Hot Chili Peppers en de regisseur van hun videoclip voor het nummer Can't stop, Mark Romanek, lieten zich inspireren door de extreme maar tegelijkertijd humoristische One Minute Sculptures van de Oostenrijkse beeldend kunstenaar Erwin Wurm (Romanek, 2002). Aan het eind van de clip wordt keurig medegedeeld dat de clip geïnspireerd is op het werk van Wurm. De Amerikaanse zangeres Beyoncé Knowles en de regisseur van haar videoclip voor het nummer Countdown, Adria Petty, kopieerden in 2011 illegaal sequenties uit de dansfilm Rosas danst Rosas (2013) van de Vlaamse choreografe Anne Teresa De Keersmaeker. De Keersmaeker besloot aanvankelijk een gerechtelijke procedure te starten tegen Knowles (Petty, 2011), later kwam ze op dit 
besluit terug. ${ }^{6}$ Legaal of illegaal: beeldtaal, idioom, bewegingen, humor en politiek engagement uit reguliere kunstdomeinen worden wereldwijd gekopieerd, in en uit voorheen vaak gesloten kunstenwerelden. Het werk van De Keersmaeker wordt op deze manier geïntegreerd in een mainstream popvideoclip en tevens gehypet als kopieerschandaal. Via de massaconsumptie van popmuziek nemen miljoenen mensen zo kennis van aanvankelijke kunstextremen die geleidelijk en schoksgewijs ons collectieve bewustzijn binnensijpelen.

Van een andere orde is het werk van de IJslandse zangeres en kunstenares Björk. In oktober 2011 kwam haar album Biophilia uit waarop al meer dan een jaar was gepreludeerd. Het album was niet zomaar een verzameling popsongs maar een 'multimedia verzameling van muziek, apps, internetsites, installaties en liveshows', zoals ze het zelf omschreef, en bovendien een samenwerking met Apple. Alles aan Biophilia heeft een onderliggende gedachte. Björk organiseert rond haar optredens muziekcursussen voor kinderen, gebaseerd op het intuïtief leren muziekmaken met behulp van iPads en apps, gekoppeld aan sterrenkundige en andere natuurwetenschappelijke verschijnselen. Elke dag van de cursus komt er een andere wetenschapper met de kinderen spreken over de relatie tussen zijn vakgebied en de muziek. De apps illustreren op een onnadrukkelijke manier hoe de liedjes zijn opgebouwd. Bjork: 'De tien nummers vertegenwoordigen elk een musicologisch element in samenhang met een natuurelement: structuur met de vorm van een kristal; arpeggio met bliksem; ritme met de regelmaat van DNA. ${ }^{8}$ Voor het album heeft zij speciale akoestische muziekinstrumenten ontworpen, zoals een combinatie van een gamelan en een celesta, een soort harmonium. Het gaat Björk om het spelenderwijs en met behulp van hedendaags technologisch 'speelgoed' leren om intuïtief zowel muziek als de onmetelijke natuur te doorgronden. Bovenstaande drie voorbeelden tonen de verwevenheid van massacultuur met gevestigde cultuurdomeinen als de beeldende kunst, de contemporaine dans en, in het geval van Björk, ook met de wetenschap.

\section{Het Zuidelijk Toneel - theater en urban space}

Vernieuwende bewegingen worden ook gezien bij de grotere gesubsidieerde Nederlandse stadsgezelschappen. Het Zuidelijk Toneel ensceneerde in 2011 de voorstelling Plot your city. ${ }^{9}$ Het stuk bestaat uit vier delen: Babel City, Panoptic City,

\footnotetext{
${ }^{6}$ De Keersmaeker lanceerde in 2013 Re:Rosas! The fABULEUS Rosas Remix Project, 'een website waar iedereen wereldwijd, van kleuters tot bejaarden, zijn eigen versie van Rosas danst Rosas kan uploaden' (Oostveldt, 2014, pp. 30-31)

${ }^{7}$ (www.bjork.com). Retrieved December 29, 2012, from http://bjork.com/\#/past/discography/biophilia

${ }^{8}$ Björk geciteerd in een interview afgenomen door Hester Carvalho (Carvalho, 2011).

${ }^{9}$ Plot your city (2011) werd in opdracht van het gezelschap geschreven door de Vlaamse toneelschrijver Paul Pourveur.
} 
Generic City en Junk City. Toeschouwers lopen met koptelefoons op van deel naar deel, met de stad waarin het stuk opgevoerd wordt als decor. Via de koptelefoon hoort men muziek, praktische informatie over de wandeling en delen van de tekst van de voorstelling. Onderweg luisteren de toeschouwers naar dialogen, door acteurs midden op een druk kruispunt in de stad gespeeld, in een achterafstraatje, ergens op de eerste verdieping op een vensterbank. Een latere voorstelling van het Zuidelijk Toneel, de voorstelling Stadsgeheimen $(2011)^{10}$, was zelfs in zijn totaliteit uitsluitend per koptelefoon te volgen; de voorstelling speelde zich af op 35 verschillende plaatsen in de binnenstad van Tilburg. De toeschouwers bepalen hun eigen tempo en hun eigen scènes in een combinatie van "...theatre and urban space, architecture and machine, the research lab and the temporary festival" (Salter, 2010, p. xxxii).

\section{Interculturaliteit, intermedialiteit, internationaliteit}

Wat treffen we in de hier beschreven voorbeelden aan, wat is er nu concreet aan deze hedendaagse performances af te lezen?

In After Dubrovka zien we een ogenschijnlijk theatrale setting, een podium en een traditionele publieksopstelling van gekromde rijen pluchen stoelen. Bij aanvang blijkt echter dat er sprake is van een rolwisseling zoals Fischer-Lichte die in veel eigentijdse voorstellingen opmerkt: de toeschouwers zijn een deel van de tijd de performers (Fischer-Lichte, 2004, p.63). Het belang van de voorstelling lijkt meer te liggen in haar presentatie van een vraagstuk, uitmondend in een publiek debat na afloop dan in haar representerende narrativiteit of in haar esthetiek, die rommelig en slordig genoemd kan worden. Technologie speelt een centrale rol, het soundscape van de uitgesproken teksten komt via koptelefoons binnen bij de 'performers' op het podium. De problematiek die wordt aangekaart, verbindt het lokale met het internationale perspectief: in hoeverre is het lokale nog los te zien van globaliserende culturele, sociale en politieke bewegingen?

In $O_{-}$Rex zien we eveneens een rolwisseling tussen publiek en performer, in dit geval van één persoon. Daarnaast zijn de technici en de begeleider van de vrijwillige hoofdpersoon niet op te vatten als acteurs in de traditionele zin. Zij spelen geen rol, ze zijn zichzelf als technici van het gezelschap CREW. Het publiek ziet ze rondlopen terwijl ze hun werk doen in de voorstelling. De rol van de technologie is, zoals altijd in voorstellingen van CREW, in feite een hoofdrol. CREW bevraagt in al zijn werk de stand der technologische dingen, de mogelijke betekenis en bruikbaarheid van technologie voor het verruimen van de dramaturgie met meer lagen. Hier openen zich nieuwe dimensies voor wat betreft een dramaturgie van de nevenschikking of parataxis

\footnotetext{
${ }^{10}$ Stadsgeheimen (2011) werd in opdracht van het gezelschap geschreven door Marcel Osterop als acteur/schrijver verbonden aan het gezelschap.
} 
(Lehmann, 1999, p. 146). Het thema en de tekst van O_Rex zijn bruikbare residuen uit de theatertraditie, waarmee een voorstelling te maken is waarin lotsbestemming en zelfgekozen blindheid verbonden worden met het vraagstuk van de beleving van virtuele werelden en met de vraag wat 'zien' vandaag de dag nog betekent. Voor de toeschouwers is het ingezette technologische geweld inmiddels voor een groot deel gemeengoed. Dit soort middelen kan gezien worden als deel van de gehanteerde performancetekst. Opgevoerd in gevestigde zalen van een nog dominant te noemen theatercultuur zijn de in deze voorstellingen gehanteerde middelen emergent te noemen.

In de videoclipvoorbeelden van de Red Hot Chili Peppers, Beyoncé en Björk kan gesproken worden van interculturele tendensen. Bij de Peppers zien we een mengvorm van de internationaal gevestigde beeldende kunst van Erwin Wurm , 'hoge' cultuur, met wereldwijd succesvolle popmuziek, 'lage' cultuur. Het beeldende absurdisme van Wurm vloeit hier samen met funkrock uit Californië. Dit is vergelijkbaar met wat er te zien is in de clip van Beyoncé, de wereld van de hogere danskunst wordt ingezet om te vervloeien met de populaire cultuur van internationaal hoog aangeslagen popmuziek. In het werk van Björks Biophilia vermengen zich diverse als culturen op te vatten sferen: popmuziek meets wetenschap meets beeldende kunst meets angelsaksische muziekonderwijsstrategieën. In deze drie voorbeelden wordt populaire cultuur geïnjecteerd met beelden, idioom en esthetiek afkomstig uit gevestigde culturele en wetenschappelijke domeinen. Daar waar het bij deze vermenging vermoedelijk gaat om het streven naar een vorm van meerwaarde, is er bij een vermenging andersom, waarbij populaire cultuur geïnjecteerd wordt in gevestigde podiumkunst, vaak sprake van een kritische dimensie. ${ }^{11}$

In het voorbeeld van het Zuidelijk Toneel wordt een toneelstuk in delen opgevoerd. Het bijwonen van de voorstelling betekent tegelijkertijd onderdeel worden van het dagelijks leven van de stad. Het werkelijke leven vermengt zich met het fictieve van de gespeelde theatertekst. Een groot gesubsidieerd theatergezelschap experimenteert met ervaringstheater, waarbij de ervaring belangrijker lijkt te worden dan de te decoderen betekenis van de tekst. De tekst is eerder leidraad voor de voorstelling dan de belangrijkste drager van betekenis. Hier kruisen culturen van de literatuur, van de technologie, van de stedelijke omgeving en architectuur elkaar.

Tenslotte kijk ik ook nog even terug naar het voorbeeld waarmee het voorwoord begon. Daar schreef ik al over het intermediale karakter van de werkwijze van

\footnotetext{
${ }^{11}$ In de voorstelling The Truth about Kate (2014), geschreven door Jibbe Willems in een regie van Davy Pieters en geproduceerd door Frascati Producties Amsterdam, speelt Naomi Velissariou in een solo een jong meisje met de ambitie om een popster te worden. Alle clichés worden uitvergroot. 'Pieters toont de extreme consequenties van het verlangen van een gewoon meisje om te leven als een superster.' (Kouters, 2014). De voorstelling werd in 2014 geselecteerd voor het Nederlands Theaterfestival.
} 
Missotten. Dit intermediale staat tegelijkertijd voor interculturele praktijken. De filmcultuur is in historisch perspectief een andere cultuur dan de theatrale of de literaire. In producties als WeerSlechtWeer, ontmoeten die culturen elkaar. Voor de makers is dit een uitgemaakte zaak, voor de publieksgroepen van deze cultuurtradities is het nog niet altijd even vanzelfsprekend. Het in elkaar overvloeien van film, literatuur, theater, scenografie, belichting en geluidstechnologie lijkt echter met de dag meer gemeengoed te worden door onze gewenning aan een digitale gelijkschakeling van informatiedragers en artistieke hulpmiddelen. Daarmee zijn de uitwisselingsgebieden, de grensstreken tussen diverse culturen, media en internationale gemeenschappen, de vitale arena's aan het worden van performatieve disciplines. In deze grensstreken raken cultureel dynamische ontwikkelingen elkaar en wordt interculturele, intermediale en internationale performativiteit manifest. In de voorbeelden zien we hoe postdramatische en performance-aspecten als rolwisselingen tussen publiek en performers, de presentatie van een specifieke realiteit of vraagstuk, de rol van technologie bij intermediale strategieën, de verruiming van dramaturgische mogelijkheden, groeiende internationale perspectieven, interculturele vermenging van bijvoorbeeld 'hoog' en 'laag' en ervaringstheater zich in de huidige artistieke praktijk manifesteren.

\subsection{Theater en culturele dynamiek}

Met dit onderzoek wil ik zoals gezegd een aantal 'diepteboringen' uitvoeren in de vorm van vier casestudies en de verhouding bevragen van deze exemplarische contemporaine theaterinstituties tot culturele dynamiek. Door in kaart te brengen hoe traditionele theaterpraktijken en theaterinstituties zich verhouden tot intermediale, interculturele en internationale ontwikkelingen, wil ik zicht krijgen op de relatie tussen gevestigde theaterinstituties en contemporaine culturele dynamiek. Wat mij bezighoudt, is de vraag of deze wisselwerking theaterinstituties doet veranderen en zo ja hoe. Door met een open blik naar deze samenhang te kijken en door de culturele context van het veranderingsproces bij de analyse te betrekken, wil ik een bijdrage leveren aan het begrip van het hedendaags theater. De centrale vraag van deze studie kan nu als volgt geformuleerd worden:

Hoe manifesteert hedendaagse culturele dynamiek, gekenmerkt door technologische, interculturele en globaliserende ontwikkelingen, zich in contemporaine theaterinstituties en op welke wijze draagt het hedendaagse theater zelf bij aan deze culturele dynamiek? 
Om een beter zicht te krijgen op het onderzoeksdomein en op de belangrijkste onderzoekstermen uit deze centrale vraagstelling, is het nodig hier stil te staan bij de termen culturele dynamiek en contemporaine theaterinstituties.

\section{Culturele dynamiek}

Cultuur is vaak gezien als statisch en als een essentie. Bovendien is het cultuurbegrip vaak smal opgevat als het specifieke geheel van 'hoge' kunsten. Raymond Williams heeft als een van velen naar voren gebracht dat cultuur niet stilstaat, maar beweegt (Williams, 1977). Ook verdedigde hij dat cultuur veel ruimer is (Williams, 2002). Ook zogeheten 'lagere' cultuuruitingen en gewone sociale levensvormen behoren volgens hem tot het culturele domein. De opvatting dat cultuur beweeglijk is, geldt voor alle tijden. In elke historische periode is in meer of mindere mate sprake van specifieke tijdgebonden turbulentie in het culturele leven onder invloed van bijvoorbeeld politieke verschuivingen, baanbrekende wetenschappelijke vindingen, grote veranderingen in productiemethoden en -verhoudingen. De industriële revolutie bijvoorbeeld heeft vanaf het eind van de achttiende eeuw naast veranderende productiemethoden ook met zich meegebracht dat voor veel kunstenaars, schrijvers en wetenschappers het wereldbeeld ging kantelen, met alle gevolgen van dien voor de manier waarop ze dat in hun werk terecht lieten komen en voor de manier waarop hun werk ontvangen werd door het publiek. Het schilderij Rain, Steam and Speed van de Britse schilder J.M.W. Turner uit 1844 toont een in bruine tinten weergegeven brug over de Theems met daarop een vaag beeld van een op de kijker afkomende stoomlocomotief (Turner, 1844). 


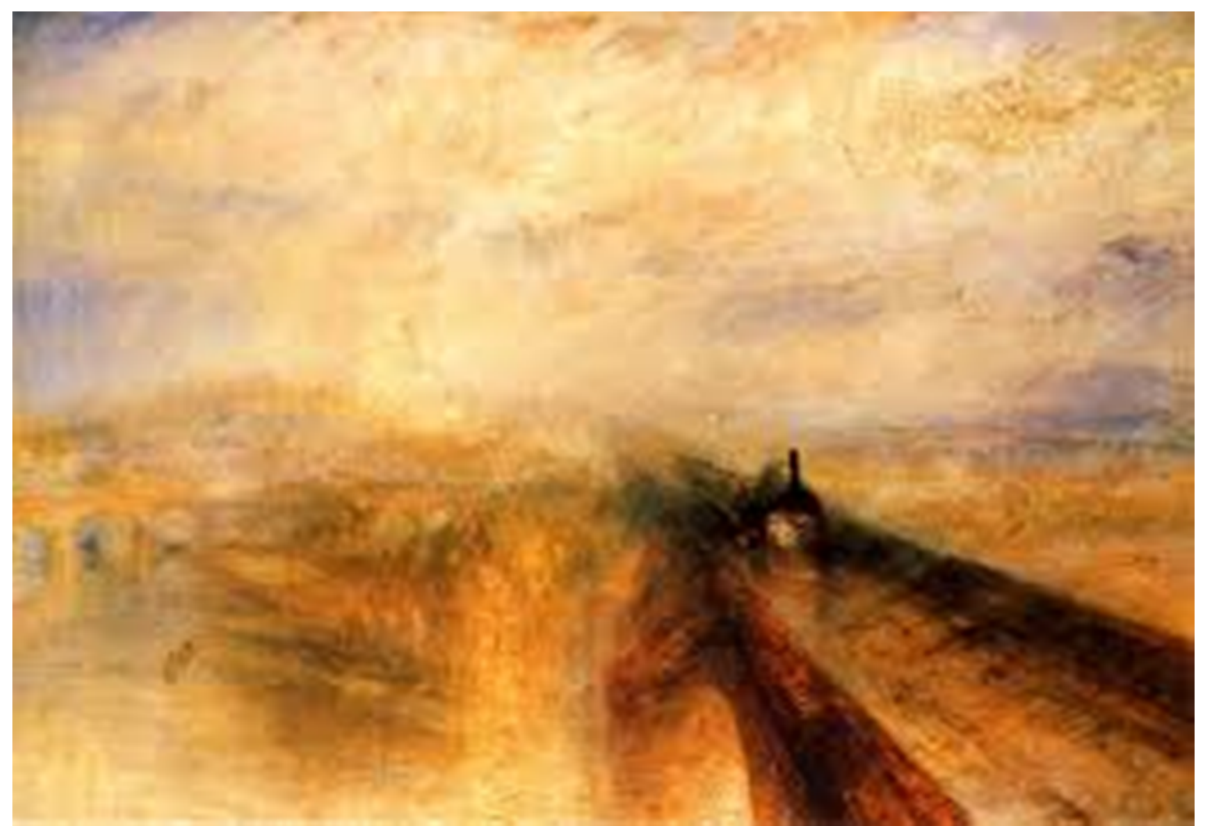

Fig. 1 J.M.T. Turner. Rain, Steam and Speed (1844)

Alleen al dat iets dergelijks object kon zijn voor een kunstenaar om te schilderen en ook nog met een techniek die vaart en vluchtigheid suggereert, was halverwege de negentiende eeuw iets volledig nieuws dat een grote impact had op de kunstenwereld en haar publiek. Wat dit soort werken losmaakte in kunst en samenleving, is cultureel dynamisch te noemen. Ruim een halve eeuw later leidden de reacties van de intelligentsia en de kunstenaarswereld op de Eerste Wereldoorlog en de gehele politiek-maatschappelijke constellatie van de jaren tussen 1910 en 1920 tot kunststromingen als Dada, het kubisme, het futurisme en tot heftige reacties daarop in de culturele wereld en in het openbare maatschappelijke leven. Na de Tweede Wereldoorlog heeft het wereldwijde dekolonisatieproces en de veranderende machtsverhoudingen die dat met zich meebracht, andere wereldbeelden opgeleverd en daarmee gepaard gaand andere manieren om die weer te geven, zeker in combinatie met de ontwikkeling en de impact van het medium televisie. Deze combinatie zorgde voor een cultureel dynamische stroomversnelling van de beeldjournalistiek, voor een tot dan toe ongekend bereik van internationale berichtgeving, voor de ontwikkeling van een media-esthetiek en voor nieuwe vormen van entertainment. Elk tijdperk kent zo zijn eigen aanjagers van specifieke verschuivingen van culturele beleving, van culturele uitingen en middelen, van culturele dynamiek. 
In onze tijd wordt culturele dynamiek in hoge mate gekarakteriseerd door de ontwikkeling van netwerken (Castells, 1996). Deze netwerken krijgen hun specifieke hedendaagse vorm door een tijdgebonden samenspel van technologische ontwikkelingen (digitale technologie), interculturele uitwisselingsprocessen (migratie van mensen en ideeën) en tendensen van internationalisering (toenemende wereldwijde mobiliteit en connectiviteit). In de culturele wereld wordt deze driedimensionale verbondenheid ervaren als een samenhang met verstrekkende gevolgen. In de programmanotitie van het NWO-programma 'Culturele Dynamiek 2007-2013' van maart 2007, staat in een omschrijving van het onderzoeksterrein het volgende:

'De perceptie van verschillen in groepsculturen, van historische identiteit en van de culturele dimensie van innovatieprocessen heeft bij de analyse van die problematiek een groeiende betekenis gekregen. Cultuur is daarmee ongemerkt in het hart van het probleem komen te staan, niet alleen als een beslissende factor bij de vormgeving van het maatschappelijk leven, maar ook en vooral als een centrale dimensie van de perceptie, de analyse en de prospectie van de maatschappelijke ontwikkeling. Met andere woorden, de factor cultuur kan niet langer ongestraft worden verwaarloosd. Maatschappelijke dynamiek wordt voortaan ook, en in veel opzichten op de eerste plaats, herkend als culturele dynamiek, die moet worden gelokaliseerd en vorm kan krijgen in naar ruimte, tijd en omvang wisselende en beperkte culturele kaders' (NWO, 2007, p. 3).

Maatschappelijke dynamiek die herkend kan worden als culturele dynamiek en die daarmee in het hart van sociaal-culturele reflectie terecht is gekomen; een dergelijke notie van wat culturele dynamiek is en vermag, vergroot het gewicht van kunst en cultuur en maakt haar breder en belangrijker dan kunst, populaire cultuur en cultureel erfgoed in engere zin. ${ }^{12}$ Daar waar hedendaagse culturele dynamiek raakt aan het theater, zien we de ontwikkeling van netwerken. We zouden in dit verband kunnen spreken van een spectrum van performatieve uitingen, een samenhangende verzameling van opvoeringen, vertoningen, installaties of voorstellingen gekenmerkt door aspecten van enscenering. Veel sectoren waarin sprake is van combinaties van spel, belichting, taal, projectie, narratieve structuren, cameravoering, vormgeving, montage, stemtechniek en meer, kortom van performatieve aspecten, kunnen gezien worden als structureel in netwerken met elkaar verbonden door met elkaar vergelijkbare kenmerken van enscenering en door de overlapping van professionele circuits, van aangewende gereedschappen, (vorm)taal en technologie. Hierbij is in

\footnotetext{
${ }^{12}$ Zie ook: Trienekens, S. (2009) Kunst in het hart van de samenleving. Over burgerschap en culturele dynamiek. Amsterdam: Hogeschool van Amsterdam Publicaties.
} 
ieder geval sprake van een of meer toeschouwers die het werk van een of meer acteurs of performers bekijken, beluisteren of beleven, live dan wel gemediatiseerd. De hier bedoelde dynamiek van vakmatige uitwisselingen, resonanties en tijdelijke allianties raakt niet alleen het gevestigde theater, maar reikt tot in artistieke praktijken die voorheen meestal als afzonderlijke cultuurdomeinen beschouwd werden, zoals film, videokunst, performancekunst, mode, documentairekunst, digitale media, fotografie, taal, muziekindustrie, reclamewereld, politiek activisme, technologie, bedrijfsleven en wetenschap. Het theater wordt op zijn beurt ook weer geraakt vanuit deze andere dan strikte canonieke kunstparadigma's.

Deze resonanties en uitwisselingen kunnen geanalyseerd en benoemd worden op het niveau van hun performance, van hun ensceneringskenmerken. Ze kunnen opgevat worden als onderdeel van de bredere culturele dynamiek.

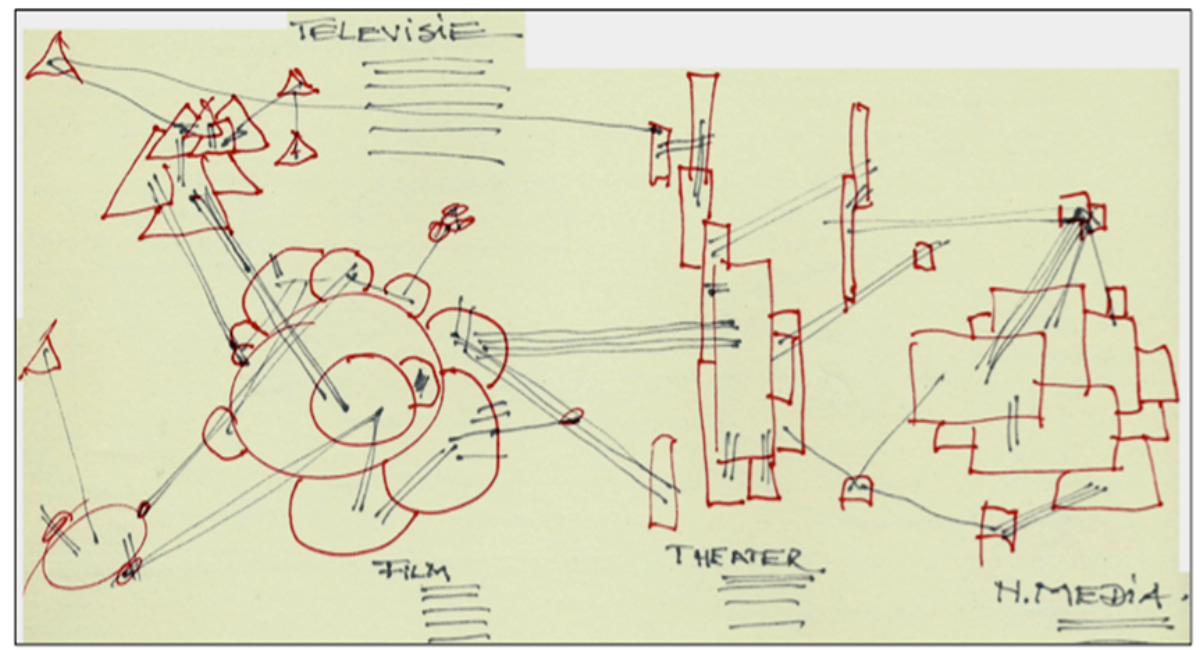

Fig. 2 Spectrale samenhang van het esthetisch performatieve (Illustratie H.Havens).

Om de specifieke aard van deze samenhang te benoemen gebruik ik de term spectrum. Een (kleuren) spectrum wordt gevormd door het geleidelijk overlopen van de ene kleur in een andere. Langzaam verloopt rood naar minder rood naar meer geel, daarna naar minder geel en meer groen, in de richting van blauw en violet. Daardoor kan men zich afvragen hoeveel blauw er in oker zit, of hoeveel oranje in groen. Vertaald naar het vakgebied van het theater in de huidige context zou men op dezelfde manier kunnen spreken van meer en minder camera, meer en minder muziek, meer en minder computer, meer en minder cinema, meer en minder taal, meer en minder urban, meer en minder dans, meer en minder traditioneel opgeleid, enzovoorts, in diverse paradigma's binnen en buiten de tot nu toe traditionele theaterkunst. Hoeveel film zit 
er in mode? Hoeveel traditioneel theater in urban? Wanneer gaat dans over in danstheater? Vanaf welk punt noemen we een voorstelling hybride? Dit soort overgangen heeft gevolgen voor de samenstelling en de organisatie van gezelschappen, voor podia en publiek, voor opleidingen en voor het kunst- en cultuurbeleid van de overheid.

Als we naar het performatief spectrum kijken als een deelverzameling van bredere hedendaagse culturele dynamiek, komt een aantal zaken mogelijkerwijs en in meer of minder grote mate van intensiteit bij elkaar: theater, bedrijfsleven, wetenschap, nieuwe media, popmuziek, beeldende kunst, film, dans, performance, kunsttaalontwikkeling, verschuivende culturele identiteiten en een wereldwijde markt met een miljoenenpubliek. Hier toont zich een hybride gebied waarbinnen betekenissen en ervaringen gegenereerd worden door kunstenaars die op diverse niveaus intermediaal, intercultureel en internationaal met elkaar in verbinding staan. ${ }^{13}$ Door bewegingen en verbindingen tussen traditionele en nieuwe performatieve praktijken krijgen nieuwe artistieke arena's vorm. Binnen bestaande theaterinstituties zijn signalen waar te nemen waaruit blijkt dat men tracht toenadering te zoeken tot deze nieuwe arena's, in thematiek en in manieren van werken, om zich geëngageerd te verhouden tot de nieuwe tijd. In de gevestigde theaterwereld wordt zo gezocht naar mogelijkheden om in dialoog te treden met de wereld van het esthetisch performatieve buiten het theater, waar in sommige gevallen innovaties sneller vorm krijgen dan in de traditionele kunstkring.

\section{Contemporaine theaterinstituties}

De keuze voor de vier theaterinstituties gezelschap, podium, opleiding en beleid verdient toelichting omdat mijn benadering enigszins afwijkt van de benadering die in de Nederlandse theaterpraktijk het afgelopen decennium gebruikelijk was: het denken in ketens. In beleids- en bestuurskringen van de Nederlandse theatersector spreekt men sinds de vanaf 2003 ingezette hervormingen van de subsidiesystematiek over ketens. Het keten-denken gaat uit van een verband van oorzaak en gevolg, en van opeenvolging. De samenhang tussen de fases in het artistieke productieproces wordt hierbij gezien als een temporele. Als schakels in de keten worden de volgende fasen gedefinieerd: scheppen $\rightarrow$ produceren $\rightarrow$ programmeren $\rightarrow$ publieksopbouw. We kunnen ons echter afvragen of deze lineair gedefinieerde keten van artistieke

\footnotetext{
${ }^{13} \mathrm{Ik}$ beperk me voor wat betreft interculturaliteit in deze studie niet tot de tegenstelling westers-nietwesters, maar spreek ook over interculturele ontwikkelingen tussen digitaal en analoog, tussen culturele industrie en canonieke cultuur of tussen 'hoge' en 'lage' cultuur. Internationale culturele uitwisseling is vandaag de dag standaard te noemen, zowel in gespecialiseerde wereldwijde kunstkringen van ingewijden als voor de geglobaliseerde cultuurindustrie of voor door politiek engagement gekleurde community art.
} 
productie tegenwoordig niet tekortschiet om te vatten wat er in de huidige artistieke praktijk plaatsvindt.

In mijn perceptie van het in de loop der tijd gevormde theatersysteem vormen de eerste twee schakels van de keten, scheppen en produceren, samen de productiepijler van het gezelschap en de tweede twee schakels, programmeren en publieksopbouw, de distributie- of afnamepijler van de podia. ${ }^{14}$ Daarbij acht ik het Nederlandse theatersysteem van na 1945 niet meer compleet zonder de opleidingen ${ }^{15}$, tevens op te vatten als instituten voor vakreflectie en kennisontwikkeling, en het Nederlandse cultuurbeleid; ook de overheid is sinds 1945 onmiskenbaar institutioneel actor geworden in het kunstenveld.

Kijkend naar het Nederlands-Vlaamse theatersysteem lijkt het me van belang om in de eerste plaats de relaties te zien die historisch gegroeid zijn tussen producenten (via theatergezelschappen), consumenten (via podia), opleiders en kennisontwikkelaars (via instituten voor theateronderwijs en practice based onderzoek) en bestuurders (via cultuurbeleidsgremia). De samenhang is in mijn ogen niet zozeer temporeel consecutief als wel voortdurend interactief. In figuur 3 is deze samenhang eenvoudig schematisch weergegeven.

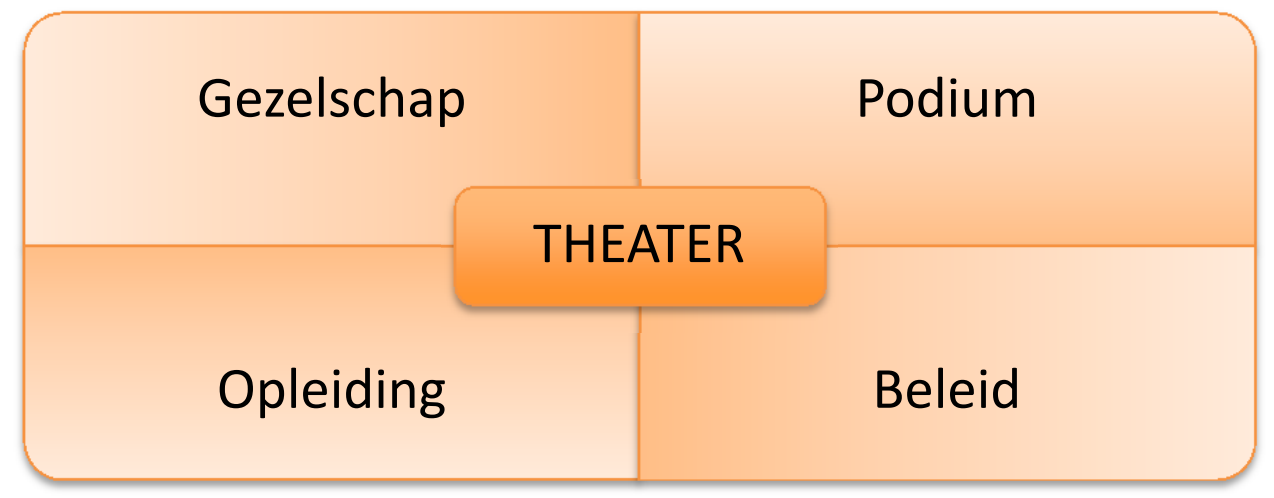

Fig. 3 Theatersysteem in Nederland (Schema H. Havens).

\footnotetext{
${ }^{14}$ Ik gebruik de term theatersysteem op dezelfde manier als Hans van Maanen (2008). Hij baseert zich bij zijn keuze voor de term systeem onder meer op een artikel van Miranda Boorsma (2001). Boorsma benadrukt dat het in netwerken niet alleen gaat om machtsstrijd maar ook om samenwerking en constructieve dialoog, om het spel tussen vraag en aanbod optimaal te coördineren.

${ }^{15}$ Tot de opleidingsinstituties die professionals aanleveren voor de contemporaine theater-/performatieve praktijk dienen niet alleen gevestigde theateropleidingen gerekend te worden maar ook bijvoorbeeld universitaire faculteiten geesteswetenschappen (filosofie, theaterwetenschap, sociologie), technische faculteiten (digitale apparatuur), beeldende kunstfaculteiten (scenografie, fotografie) en muziekopleidingen.
} 
De institutionele pijlers van de Nederlandse theaterpraktijk kunnen zo in abstracto worden gezien als op elkaar inwerkende elementen van een systeem. Dit theatersysteem wordt door verschillende soorten overheidssubsidies formeel gesanctioneerd; het is daarmee onderdeel van een in de kunstenwereld lang als richtinggevend of dominant beleefde cultuursector.

Het bestaande theatersysteem van gezelschappen, podia, opleidingen en overheidsbeleid heeft in Nederland zijn vorm gekregen vanaf 1945. Het werkte op papier als volgt: theateropleidingen leidden jonge mensen in principe op voor het gesubsidieerde theater. Het gesubsidieerde theater speelde zijn voorstellingen in de regel in schouwburgen, in vlakkevloertheaters of in functioneel vergelijkbare zalen en zaaltjes. De rijksoverheid subsidieerde de theatergezelschappen en de theateropleidingen met behulp van een peer review-systeem op basis van een door het politieke klimaat gekleurde beleidsvisie. Lokale overheden werden verantwoordelijk voor de schouwburgen en andere podia. ${ }^{16}$ Het ongesubsidieerde theater werd in de regel gereguleerd door de vrije markt van de entertainmentindustrie. Dit systeem is in grote lijnen nog steeds intact, al is er in de loop van de afgelopen decennia op bepaalde punten nogal wat veranderd. Tussen 1945 en 1970 heeft het systeem min of meer gewerkt zoals dat bij constitutie werd gedacht. Er werd ingezet op de horizontale (regionale) en verticale (sociale) spreiding van canoniek theater over het gehele land; gezelschappen werden gefaciliteerd, schouwburgen gebouwd, toneelscholen gesticht en beleid geformuleerd. Na de Aktie Tomaat in het najaar van 1969 werd alles anders en is het Nederlandse theater explosief gefragmentariseerd. ${ }^{17}$

De toenmalige Nederlandse minister van Cultuur, Marga Klompé, maakte hierna met haar innovatieve subsidiepolitiek ruimte voor een andere benadering van overheidssteun dan voorheen gebruikelijk was; de overheid investeerde voortaan ook in onderzoek en experiment in de kunst in plaats van alleen maar in conservering van cultureel erfgoed. De periode rond 1970 kan beschouwd worden als een belangrijk scharnierpunt in de theatergeschiedenis van de Lage Landen. Deze periode is in de afgelopen decennia meerdere malen uitvoerig beschreven (Oosterbaan Martinius,

\footnotetext{
${ }^{16}$ In de hoofdstukken 4 en 6 kom ik terug op deze specifiek Nederlandse situatie van gescheiden financieringstrajecten voor producerende gezelschappen aan de ene kant (Rijk) en podia aan de andere kant (gemeenten).

${ }^{17}$ Op 9 oktober 1969 vond in de Amsterdamse Stadsschouwburg de Aktie Tomaat plaats.

Toneelschoolstudenten, studenten theaterwetenschap en hun sympathisanten gooiden tijdens de première van De Storm van Shakespeare door de Nederlandse Komedie tomaten naar de spelers om debat en dialoog over het Nederlandse theater af te dwingen (Meyer, 1994).
} 
1990; Meyer, 1994; Van Maanen, 1997; Lehmann, 1999; Pots, 2000; Krans, 2005). ${ }^{18}$ Vanaf 1970 heeft er een transitieproces plaatsgevonden van canoniek publiekstoneel naar een theater op te vatten als onderzoekskunst. Ellen Walraven schrijft over deze omslag als over een paradigmawisseling, een overgang van publiekstheater naar kunsttheater, waarmee tevens talrijke onderlinge relaties in het theatersysteem geraakt worden. "Voor alle "spelers" (aanbodzijde, afname, publiek en overheid) veranderen de "bestelcoördinaten" van het Nederlandse theater in de loop van de jaren zeventig en tachtig fundamenteel', zo schrijft ze (Walraven, 2007). De positie van gevestigde theaterinstituties als deel van een culturele hoofdmacht kwam hierdoor steeds meer onder druk te staan. Theatrale scheppingsprocessen verliepen lang niet altijd meer zoals door de structuur van instituties verondersteld zou kunnen worden. Waardevol geachte geënsceneerde cultuuruitingen waren niet meer uitsluitend te beleven bij traditionele gezelschappen die canoniek theater brachten. Voorstellingen werden niet meer alleen in schouwburgen of in vlakkevloertheaters gespeeld of getoond. Theateropleidingen gingen ook opleiden voor allerlei andere artistieke beroepsvelden dan alleen voor het gesubsidieerde theater. Bovendien bleek de overheidssubsidiëring van theater erg ingewikkeld geworden vanwege politieke of ideologische legitimiteitsproblemen en vanwege het groeiende aantal moeilijk te categoriseren nieuwe performatieve praktijken.

De artistieke vrijheid en het door de overheid sanctioneren daarvan heeft de afgelopen decennia een grote diversiteit opgeleverd van productievormen en organisaties. Daarnaast is dit gegroeide aanbod ook in verband te zien met de groei van het aantal kunstopleidingen en met andere kanalen waarlangs jonge mensen in artistieke beroepsdomeinen terechtkomen. Het gaat niet meer uitsluitend om gericht opgeleide professionals die via gevestigde Nederlandse hbo- theateropleidingen het theatervak bevolken. Acteur, performer, theatermaker, videokunstenaar, modeontwerper, beeldend kunstenaar, danser, klassiek musicus, popmusicus, interactief designer, het zijn geen van alle beschermde beroepen. Er is sprake van een groeiende heterogene instroom in een meer hybride wordende sector van artistieke beroepen. De kunde lijkt steeds minder een probleem, het vermogen om zichzelf met toereikende bagage, autonoom of toegepast, te positioneren of te herpositioneren in een uitdijend artistiek beroepsveld, lijkt dat nog wel. ${ }^{19}$

Blijft de vraag: kunnen we in het begin van de 21 e eeuw het theater nog als één gekaderd domein definiëren? Hoe is in dit differentiatieproces de waarde van al die verschillende brondomeinen te benoemen, die samen de context vormen van het gevestigde theater? Wat is daarbij de rol van hybride performatieve vormen waarbij

\footnotetext{
${ }^{18}$ Het boek van Lehmann heeft in een internationale context veel bijgedragen aan de reputatie van het innovatieve theater van de Lage Landen uit de jaren zeventig, tachtig en negentig.

${ }^{19}$ In Hoofdstuk 5, over het theatervakonderwijs, kom ik hierop terug.
} 
andere kunstdisciplines als film, televisie, dans, beeldende kunst of nieuwe media betrokken zijn? Hoe veranderen deze transitieprocessen de betekenis, vorm en werking van tot voor kort als vanzelfsprekend gedefinieerde instituties theatergezelschap, podium, theateropleiding en nationaal theaterbeleid? Om een begin van een antwoord te kunnen formuleren zal eerst in kaart gebracht moeten worden wat we aantreffen in de hedendaagse 'theater'-praktijk en hoe contextuele invloeden gevestigde theaterinstituties raken.

\subsection{Positionering van het onderzoek: de praktijk en de theaterwetenschap}

Dit onderzoek is descriptief en exploratief van aard en kan tot het domein van de theaterwetenschap gerekend worden omdat het object van onderzoek wordt gevormd door theatertransformaties die zich de afgelopen decennia in de theaterpraktijk voltrokken hebben en die zich nog steeds aan het voltrekken zijn. In de theaterwetenschap bestudeert men hedendaags theater vanuit een intermediaal, intercultureel, interdisciplinair en internationaal perspectief. Door het analyseren van de positie en werking van vier hedendaagse theaterinstituties in samenhang met de cultureel dynamische context, wil ik een bijdrage leveren aan het theaterwetenschappelijke discours rond deze transformaties.

De theaterwetenschap beleefde in de loop der tijd enkele veranderingen van perspectief: van een focus op structuren en systemen op basis van de linguistic turn in de loop van de twintigste eeuw, via de performative turn (het vluchtige, procesmatige, momentane) aan het eind van de twintigste eeuw, beleeft zij in het huidige tijdsgewricht een pictorial turn (beelden en media). ${ }^{20}$ Deze verschuivingen van perspectief zijn ook te herkennen in recente theatertransformaties, in het geleidelijk veranderen van de werkwijze van theatermakers en van het door hen gehanteerde theateridioom, van de beleidskoersen van podia en van de curricula van theaterscholen. Geënsceneerde verhalen worden in toenemende mate door diverse media in verschillende combinaties vormgegeven op basis van gesproken en geschreven taal, van digitaal beeldmateriaal, door middel van acteren voor of met een camera. Niet zelden gaan hierbij de diverse media met elkaar in dialoog.

Deze ontwikkelingen raken niet alleen de actuele theaterpraktijk maar zijn daarmee tegelijkertijd object van onderzoek voor de theaterwetenschap en voor andere verwante onderzoeksdomeinen als de geesteswetenschappen en de performance- en mediastudies. Technologische ontwikkelingen in de gemediatiseerde

\footnotetext{
${ }^{20}$ Charlotte De Somviele verwijst in haar 'Lexicon', opgenomen in Het Statuut van de tekst in het postdramatische theater, voor de herkomst van deze termen respectievelijk naar de Amerikaanse filosoof Richard Rorty, de Duitse theaterwetenschapper Erika Fischer-Lichte en naar de Amerikaanse kunsttheoreticus W.J.T. Mitchell (Swyzen \& Vanhoutte, 2011, p. 199).
} 
samenleving van het begin van de 21 e eeuw zorgen bijvoorbeeld voor een hernieuwd debat over het complexe begrip liveness (Auslander, 1999), over de relatie tussen de live performance en het opgenomen, gereproduceerde of geprojecteerde beeld. ${ }^{21}$ Interculturele ontwikkelingen verhevigen daarbij het debat over nationale culturen, identiteit en het gewicht van culturele uitingen. In de loop van de twintigste eeuw hebben deze ontwikkelingen een rol gespeeld bij het uitbreiden en definiëren van nieuwe onderzoeksterreinen rond theater, film en media.

\section{Richard Schechner}

De Amerikaanse theatermaker en theater- en performancewetenschapper Richard Schechner ${ }^{22}$ zal vanaf de vroege jaren zeventig de kiem leggen voor het relatief nieuwe kennisdomein van de performance studies vanuit een toenemende interesse voor het procesmatige, voor de interactieve en vluchtige theaterhappenings van die tijd. Als geëngageerd theatermaker stuitte hij op de grenzen van het object van de theaterwetenschap tot dan toe. Hij en velen met hem ervoeren in de loop van de jaren zestig aan den lijve de kloof tussen de toenmalige innovatief explorerende theaterpraktijk en het theatertheoretische discours. Bij Schechner ligt daarbij vanaf het begin een belangrijk accent op een antropologische benadering van het performatieve, waarin hij het westerse theater object van onderzoek maakt in de contextuele vergelijking met manifestaties en performances in andere dan de westerse canonieke theaterculturen. Vanaf de jaren zestig van de vorige eeuw heeft hij zich onder andere beijverd om op basis van deze vergelijking een radicale herbeschouwing van het klassieke theaterrepertoire te bewerkstelligen en om zowel praktische theater- en performancetrainingen als performancetheoretische opleidingen en wetenschappelijk onderzoek een intercultureel, interdisciplinair en internationaal karakter te geven. Uiteindelijk leidt dat tot de oprichting en vormgeving van een in die tijd geheel nieuw wetenschappelijk kennisdomein, de performance studies. De concepten life as performance, voor een belangrijk deel gestoeld op het werk van Irving Goffman, ${ }^{23}$ en

\footnotetext{
${ }^{21}$ Met hernieuwd refereer ik aan diverse momenten in de loop van de twintigste eeuw waarop het debat gevoerd werd over de rol van technologie en technische reproduceerbaarheid voor kunst en cultuur. Ik denk daarbij aan het debat over de culturele rol van massacultuur tussen Walther Benjamin en Theodore Adorno, of het debat tussen Benjamin en Roland Barthes over technische reproduceerbaarheid en tussen Peggy Phelan en Philip Auslander over liveness, live performance en media.

${ }^{22}$ Richard Schechner is in de jaren zestig oprichter van de in New York gevestigde Performance Group, waaruit korte tijd later de Wooster Group zal ontstaan. In de loop van de jaren zeventig wordt hij wetenschapper en staat hij vanuit de Tisch School of the Arts, New York University aan de wieg van het domein van de performance studies.

${ }^{23}$ Daarbij verwijst Schechner naar Irving Goffmans The Presentation of Self in Everyday Life (1959) (Schechner, 2002b, p. 23).
} 
restored behaviour (Schechner, 2002b, p. 28) spelen in Schechners werk een centrale rol. Deze benadering van theater, film, performances en performatief gedrag in bredere zin vormde een uitdaging voor de meer historisch georiënteerde theaterwetenschap. Eind jaren negentig vroeg Schechner zich af of er nog wel behoefte zou zijn aan traditioneel theater in de 21e eeuw. Hij zag destijds traditionele theatervormen nog wel overleven, alleen zouden de accenten anders komen te liggen. De maatschappelijke positie van het theater zou volgens hem waarschijnlijk niet meer die van behorend tot de dominante westerse schone kunsten zijn. Hij voorspelde zelfs een complete ineenstorting van alles wat tot dan toe tot de traditionele schone kunsten gerekend werd. Een paar jaar later kwam hij daar overigens op terug, publiekelijk toegevend dat op basis van het werk van toenmalige theaterkunstenaars als onder meer Pina Bausch, Robert Wilson, Robert Lepage, Ivo van Hove, Laurie Anderson, Suzuki Tadashi, Jan Lauwers, Eugenio Barba en Elizabeth LeCompte, geconcludeerd kon worden dat er nog wel degelijk sprake was van een uitermate levendig en vitaal theater in het begin van de 21e eeuw (Schechner, 2000). ${ }^{24}$ Ongeveer in dezelfde tijd verscheen Hans-Thies Lehmanns geruchtmakende boek Postdramatisches Theater (1999).

\section{Lehmanns Postdramatisches Theater}

In 1999 kenschetste Lehmann de theaterontwikkelingen tussen 1970 en 1999 door het nieuwe paradigma van het postdramatisch theater te introduceren. Met die term werd geïmpliceerd dat het westers theater eind twintigste eeuw voorbij was aan traditionele dramatische dimensies; het baseerde zich steeds vaker op andere constructieprincipes dan op die van het literaire drama. In grote lijnen werd tegenover de dramatische dimensie de lyrische dimensie belangrijker, al dan niet in combinatie met innovatieve performancetechnieken, met cinematografische vormprincipes en in toenemende mate met gebruikmaking van de mogelijkheden van digitale media. In plaats van het personage traden het lichaam en de persoonlijkheid van de acteur meer op de voorgrond, presentatie nam in veel gevallen de plaats in van representatie en in plaats van de mise-en-scène gingen montage en juxtapositie een belangrijke rol spelen. Theaterrepertoire en theaterproductiewijzen kregen een substantieel ander karakter.

Lehmann geeft zelf aan dat hij niet heeft willen categoriseren volgens bestaande kunsttheoretische of theaterwetenschappelijke etiketten, maar dat hij het toenmalige

\footnotetext{
${ }^{24}$ Richard Schechner stelde de vraag over de levensvatbaarheid van het theater in de $21 \mathrm{e}$ eeuw ook in Nederland publiekelijk op de tweede International Lecture on Performing Arts in Utrecht in 1998. In 2002 verscheen de lezing in het Nederlands vertaald en bewerkt als artikel (Schechner, 2002a). Het is niet ondenkbaar dat Schechner zijn mening toentertijd bijstelde na kennis genomen te hebben van de uitvoerige studie van Lehmann over het postdramatisch theater.
} 
theater heeft willen beschouwen met een herijkte theateresthetische blik, waarbij hij aantekende dat dit in de meeste gevallen betekende dat er ethische, morele, politieke en engagementsvraagstukken mee gepaard gingen (Lehmann, 1999, p. 15). In zijn ogen wees dit alles in de richting van het theater van de toekomst. Lehmann heeft steeds voor ogen gehad dat de door hem beschreven concepten als nieuw theatergereedschap nuttig moesten gaan worden voor de theaterpraktijk die zich in de loop van de 21e eeuw zou gaan ontrollen: "Die Beschreibung jener Formen des Theaters, die hier als postdramatisch aufgefaßt werden, ist auf Nutzung angelegt." (Lehmann, 1999, p. 16). De diagnose van de postdramatische conditie van het theater en de rol ervan is volgens Lehmann hoopvol. Dit nieuwe theater kan ons trainen om het huidige tijdsgewricht beter aan te voelen, te ervaren, om het beter te zien. Bovenal leert het ons om samen met de performers, ontwikkelingen in onze wereld te begrijpen en te benoemen. Daarbij is het van belang in te zien dat in veel van het nieuwe theater afstand genomen wordt van wat bij Lehmann Illusionsbildung heet. Hij stelt het duidelijk: dramatisch theater was het construeren van illusie; in essentie werd in dramatisch theater een fictieve kosmos gecreëerd. De voorstelling diende gezien te worden als één samenhangend geheel, als een representatie van een voorstelbare wereld. Die representatie kenmerkte het model van drama. Door het krimpen van dit imaginaire dramatische universum in de loop van de twintigste eeuw kwam de focus steeds meer te liggen bij de theatrale situatie. Volgens Lehmann hield het dramatische theater op te bestaan toen de literair dramatische elementen niet meer als regulerend principe golden, maar als mogelijke varianten binnen een bredere theaterkunst (Lehmann, 1999, p. 21-22). Deze deconstructie van het dramatische, de groter wordende afstand tussen drama en theater, tussen representatie en presentatie, tussen tekst en andere theatermiddelen, geeft Lehmanns studie een filosofische dimensie.

Daarnaast ziet hij ook een historische dimensie van het postdramatische. Lehmann betrekt theaterontwikkelingen van de gehele twintigste eeuw bij zijn duiding van het postdramatisch theater. De historische avant-garde, de absurdisten, het documentair theater van de jaren zestig, allemaal hebben ze al kiemen in zich gehad van het theater dat Lehmann aan het eind van de twintigste eeuw beschrijft. De studie van Lehmann is door zijn beschrijving van belangrijke voorlopers op te vatten als een historische herbeschouwing van ijkmomenten in de theatergeschiedenis. Opmerkelijk is daarbij dat hij de meeste voorlopers, inclusief theatervernieuwer en dramacriticaster Bertolt Brecht, toch nog voornamelijk wil beschouwen als drama-adepten. Brecht kenschetst hij als een vernieuwer van klassieke dramaturgie. De kritische dimensie van het theater van de twintigste eeuw zoals geformuleerd door de historische avantgarde en door regisseurs en theatertheoretici als Brecht, Peter Szondi en Roland Barthes, voldeed volgens Lehmann niet meer in het laatste kwart van de twintigste 
eeuw: "Diese Antwort reicht nicht mehr aus." (Lehmann, 1999, p. 41). De grootste en belangrijkste cesuur in de twintigste-eeuwse theatergeschiedenis wordt volgens Lehmann pas echt werkelijkheid doordat zich vanaf de periode rond 1970 een gemediatiseerde samenleving ontrolt.

"Gewiß brechen die Theaterrevolteure mit fast allem Hergekommenen, aber sie halten auch bei der Hinwendung zu abstrakten und verfremdenden Bühnenmitteln an die Mimesis einer Handlung auf dem Theater fest. Dagegen kommt es im Zuge der Verbreitung und dann Allgegenwart der 'Medien' im Alltagsleben seit den 1970er Jahren zum Auftreten einer neuen vielgestaltigen theatralen Diskursform, die hier als 'postdramatisches Theater' bezeichnet wird" (Lehmann, 1999, p. 22).

Het lineair successief waarnemen in het theater leek in zijn ogen plaats te maken voor het simultane en multiperspectivische. Onder andere als gevolg daarvan liet het theater zich moeilijk nog begrijpen binnen Aristotelische dramatische kaders. Het hart van het boek wordt gevormd door een uitgebreid hoofdstuk dat hij "Panorama des Postdramatischen Theaters" noemt (Lehmann, 1999, p. 113). Hij benoemt hier in korte paragrafen een verzameling waargenomen theatertransformaties, die allemaal te maken hadden met de differentiatie van theaterrepertoire, met de onthiërarchisering van theatermiddelen en met intermediale theaterproductiewijzen.

$\mathrm{Hij}$ onderscheidt veranderende theatertekens, waaronder afnemende synthese en opkomst van polyvalentie, performance als textuur, parataxis, simultaneïteit, verdichting van tekens, het overvolle, visuele dramaturgie, lichamelijkheid, concreet theater, het afstand nemen van de illusie, vermenging van het theatrale met het reële, zelfreferentialiteit. Dit soort nieuwe theatertekens leveren volgens hem een van de klassieke dramatiek afwijkende esthetiek op: de eenheid van handeling wordt veelheid van handeling; het lineair successieve wordt verruild voor complexe onlogische verbindingen; tekst wordt steeds minder een dominant sturend principe; de opvoering wordt steeds vaker beschouwd als een zelfreferentiële gebeurtenis; het vormgeven van cognitieve herkenning en betekenis maakt steeds vaker plaats voor de esthetische ervaring. Lehmann concludeerde dat we in een tijdperk terecht waren gekomen waarin de voorheen noodzakelijk coherente verhalen er steeds minder toe leken te doen. Hij nam wel een levende theatercultuur waar, maar dan een zonder hiërarchische structuren en zonder een esthetiek gebaseerd op een vastliggende set van regels. Er was sprake van een dramaturgie van de nevenschikking waarbij meerdere betekenissystemen (dans, beeldende kunst, fotografie, cinema, mode, popcultuur) hoofdrollen konden claimen bij het aansturen van artistieke performatieve processen; lichamelijkheid was lang niet altijd meer gebonden aan personages, en 
media vonden hun weg naar het podium. Volgens Lehmann was, op grond van wat zich afspeelde in toenmalige westerse theaterpraktijken, de heersende theateresthetiek aan herijking toe.

Lehmann baseerde zijn bevindingen op een uitvoerige analyse van het westerse theater tussen 1970 en 1999. Het resultaat van zijn onderzoek, de publicatie Postdramatisches Theater, ontstond vanuit de theaterpraktijk op basis van een Europees onderzoek naar het veranderende theater. Het werd uitgevoerd door theaterprogrammeurs, theaterfestivalleiders, dramaturgen en wetenschappers. Concepten die toenmalige visionaire theatermakers hanteerden, werden in onderling overleg reflectief beschouwd en becommentarieerd. Het waren concepten die aansloten bij of commentaar leverden op de tijdgeest van mediatisering, moderne volksverhuizingen en een mondiale cultuurindustrie. Gezamenlijk werkten de onderzoekers vanuit Berlijn, Amsterdam, Brussel, Frankfurt, Londen, Hamburg en Wenen aan een internationaal viertalig (Engels, Duits, Frans en Nederlands) vaktijdschrift, Theaterschrift, onder hoofdredacteurschap van de Vlaamse dramaturge Marianne van Kerkhoven. In zes jaar tijd, van 1992 tot 1998, verschenen dertien nummers, elk met een speciaal thema. De publicaties leverden door heel Europa heftige debatten op. In deze tijd van internationale heroverweging van een aantal cruciale theaterconcepten gaf een zich vernieuwende Europese theaterpraktijk de voorzet voor het onderzoek en sloot de wetenschapper Lehmann zich aan om de resultaten op schrift te stellen. Veel van het materiaal waar hij zijn nieuwe theaterparadigma op baseerde, is ontleend aan de Nederlands-Vlaamse theaterpraktijk. Namen die, naast die van kunstenaars uit de rest van de wereld, in Lehmanns boek figureren zijn die van Jan Fabre, Jan-Joris Lamers, Jan Lauwers, Maatschappij Discordia, Het Zuidelijk Toneel, Suver Nuver, Paul Koek, Ivo van Hove, Theatergroep Hollandia, Anne Teresa De Keersmaeker, Toneelgroep Stan en Theatergroep Victoria. ${ }^{25}$

\section{Het discours na Lehmann}

In de vijftien jaren na het verschijnen van Lehmanns geruchtmakende observaties lijken de door hem gesignaleerde processen van differentiëring en deconstructie zich exponentieel te hebben vermenigvuldigd. In het discours na Lehman leverde de culturele dynamiek van internationalisering, interculturaliteit maar vooral van

\footnotetext{
${ }^{25}$ Uit de toenmalige internationale theaterscène noemt Lehmann buiten de Nederlands/Vlaamse theatermakers en gezelschappen onder anderen: Robert Wilson, Heiner Goebbels, Einar Schleef, Peter Brook, Robert Lepage, Pina Bausch, William Forsythe, Meredith Monk, Meg Stuart, Tadeusz Kantor, Richard Schechner, Emil Hrvatin, Eugenio Barba, Wooster Group, Bak-Truppen, Forced Entertainment (Lehmann, 1999, pp. 24-25).
} 
mediatisering en intermedialiteit een verheviging op van de postdramatische theatertekens.

In Europa werd Lehmanns boek vanaf de publicatie vrijwel onmiddellijk een belangrijke theatertheoretische tekst genoemd. Er kwamen al snel diverse vertalingen, maar vooral door het uitkomen van de Engelse vertaling en bewerking door Karen-Jürs Munby in 2006 werd er wereldwijd kennis van genomen. Het werd een rommelig boek gevonden, onscherp en met teveel opsommingen en lijstjes. Later was er geducht commentaar op de Engelse vertaling (Fuchs, 2008), maar vriend en vijand waren het erover eens dat de issues over de staat van zijn van het westers theater die Lehmann formuleerde, niet meer te ontkennen waren. Gewaardeerd werd de wijze waarop het hem lukte om met zijn conceptuele kader binnen de grenzen van de theateresthetiek te blijven en zich niet te beroepen op sociologische, antropologische, etnografische en culturele studies (Fuchs, 2008).

Het toonaangevende Duitse theatervakblad Theater Heute wijdde in oktober 2008 een special aan de Postdramatik. Op de voorpagina: "Die süßen Versprechen der Postdramatik. Seit 10 Jahren beherrscht das Schlagwort die Debatte pro und contra". Het deel van de Duitse theaterwereld dat zwoer bij het canonieke teksttheater als onomstotelijk belangrijkste cultureel erfgoed, verketterde het postdramatische. Het meer onafhankelijke freies Theater verdedigde Lehmanns noties. De redactie opende het speciale nummer als volgt:

“Das 'postdramatisches Theater' ist die erfolgreichste Marke der jüngeren Theatergeschichte. Seit zehn Jahren spukt der Begriff, den das gleichnamige Buch van Hans-Thies Lehmann in die Welt gesetzt hat, durch die Köpfe und Debatten. Manchen gilt er als Glaubensbekenntnis, anderen als die Achse des Bösen. Er spaltet Schauspielschulen, polarisiert zwischen Freier Szene und Öffentlichen Bühnen, läßt die einen Kritiker jubeln und andere vor Wut aufheulen. Über wenig kann sich die Theaterwelt mehr aufregen, als hätte man keine anderen Probleme. Die erstaunliche Karriere verdankt sich nicht nur verschiedenen Theaterformen und -schulen, sondern auch seiner einzigartigen Unschärfe. Denn was das postdramatische Theater wirklich ist, und vor allem was nicht, klärt Lehmanns Buch in seinen facettenreichen Widersprüchen kaum. Das muß fürs Theater kein Nachteil sein, wenn was wäre langweiliger als ein uniformes Regelwerk?" (Theater Heute, oktober 2008, p. 7).

Lehmanns beschrijving van het uiteenvallen van de eenheid van dramatisch theater is ook buiten Duitsland verschillend ontvangen. Het koepelbegrip postdramatisch theater deed in de internationale theaterpraktijk en onder theatertheoretici veel stof 
opwaaien. ${ }^{26}$ Begrijpelijkerwijs werd in landen met een sterke talige theatertraditie over het algemeen zeer kritisch gekeken naar Lehmanns noties, terwijl bijvoorbeeld in Nederland en Vlaanderen het postdramatische nagenoeg onmiddellijk gemeengoed was.

Binnen de theaterwetenschap ontrolde zich na de publicatie een discours rond dichotomieën als woord en beeld, betekenis en ervaring, theater en performance, representatie en presentatie, en performativiteit en narrativiteit. Daarbij viel op dat, behoudens in enkele gerichte kritieken, er inhoudelijk nauwelijks gereageerd werd op Lehmanns boek als geheel, op de manier waarop hij de eindtwintigste-eeuwse theateresthetiek trachtte te analyseren. Wel werden centrale begrippen uit zijn panorama van het postdramatische theater door diverse theater- en performancetheoretici als concepten los van elkaar geanalyseerd en gedefinieerd (Fischer-Lichte, 2004; Dixon, 2007; Kattenbelt, 2006, 2010; Auslander, 1999; Swyzen \& Vanhoutte, 2011). Voor sommige van die concepten geldt overigens dat ze al langer object van onderzoek waren: discoursen rond concepten als performance en liveness lopen zoals eerder vermeld al veel langer dan 1999, Lehmann heeft met zijn publicatie daaraan een bijdrage geleverd. Hierna geef ik enkele exemplarische voorbeelden uit het discours na Lehmann.

De binnen de theaterwetenschap gezaghebbende Erika Fischer-Lichte publiceerde in 2004 haar Ästhetik des Performativen, waarin ze de relatie tussen het theatrale en het performatieve uitdiept in de richting van het belangrijker wordende performanceconcept. ${ }^{27}$ Ook besteedt ze aandacht aan het ingewikkelde begrip liveness, aan een verheviging van de lichamelijkheid (Körperlichkeit) in de podiumkunsten, aan de ervaring en het evenement als constituerend element, aan rolwisselingen tussen toeschouwer en performer, aan de dichotomie presentatie en representatie (Präsentation en Repräsentation) en aan het begrip aanwezigheid (Präsenz) in de huidige esthetiekdiscussie (Fischer-Lichte, 2004). Waar Lehmann nog spreekt over een nieuwe theateresthetiek als koepelbegrip, verschuift Fischer-Lichte de focus door al deze ontwikkelingen onder te brengen in de richting van een esthetiek van het performatieve:

\footnotetext{
${ }^{26}$ Lehmann muntte het begrip door er een boek over te publiceren, de term is echter al ouder dan 1999. Lehmanns collega hoogleraar op het door hun beiden opgerichte Institut für Angewandte Theaterwissenschaft in Giessen, Andrzej Wirth, gebruikte de term al in de zeventiger jaren en schreef er zelfs al over in de jaren tachtig van de vorige eeuw (Fuchs, 2008).

${ }^{27}$ Vanaf 2008 werd de Duitse publicatie wereldwijd bekend door de publicatie in dat jaar van de Engelse vertaling en bewerking van het boek, met een inleidend hoofdstuk van de hand van Marvin Carlson. FischerLichte, E. (2008). The Transformative Power of Performance. A new Aesthetics (S.I. Jain, Trans.) London/New York: Routledge. (Oorspronkelijke uitgave 2004)
} 
"Seit der performativen Wende in den sechziger Jahren haben Theater, Aktionsund Performance-Kunst eine Fülle von Verfahren entwickelt, welche die Aufmerksamkeit gezielt auf die performativen Hervorbringung von Materialität in der Aufführung lenken und -in der Tat wie in einem Forschungslaborunterschiedliche Bedingungsfaktoren und Vollzugsmodi hervorheben und fokussieren“ (Fischer-Lichte, 2004, p. 128).

In lopende kunsttheoretische debatten vallen concepten op die zich verhouden tot het verschil of de overeenkomst tussen theater en performance, en tot de digitale media. Centraal in het debat over de verhouding tussen live performance en gemediatiseerde varianten staat de sterke band die al of niet wordt verondersteld tussen producerende mediastructuren (mediabedrijven, televisiestations, internetproviders, gameproducenten, muzieklabels) en het economische establishment, en het effect daarvan op de autonomie en authenticiteit van kunstenaars. Vanaf de jaren negentig van de vorige eeuw spelen de Amerikaanse wetenschappers Philip Auslander en Peggy Phelan hierin een polariserende rol. De Britse acteur en academicus Steve Dixon analyseert deze controverse tussen Auslander en Phelan. Auslander beweert volgens Dixon dat de live performance en het theater inmiddels voor een groot deel gemediatiseerd zijn en dat dit te accepteren is als eigentijds. Daartegenover verdedigt Phelan volgens hem dat live performances juist autonomie en authenticiteit in zichzelf dragen, waarmee ze het kritisch bewustzijn van een samenleving zouden belichamen, in tegenstelling tot de volgens haar altijd economie- en establishment afhankelijke media (Dixon, 2007, pp. 122-125).

In Europa wordt twee decennia later vanuit een iets ander perspectief gekeken naar dit discours rond de relatie tussen de live performance en de media. De visies van Auslander en Phelan werden gekleurd door een Amerikaanse context, in die tijd nog vrijwel geheel beheerst door de impact van televisie (the televisual). Vandaag de dag dient het debat volgens de Nederlandse theaterwetenschapper Chiel Kattenbelt, en met hem een substantieel contingent hedendaagse theaterwetenschappers, niet zozeer vanuit de genoemde polariteit bezien te worden, maar meer vanuit het perspectief van complexe onderlinge verhoudingen tussen diverse media en kunstendisciplines, waarbij intermedialiteit als een centraal concept beschouwd kan worden. Op grond daarvan betekent toepassing in het theater van diverse technologische middelen niet per definitie een ontheiliging van het theatrale, maar in veel gevallen juist de intensivering van het fysieke in de confrontatie van de performer en de toeschouwer (Chapple \& Kattenbelt, 2006, pp. 15-16). Daar waar Auslander en Phelan debatteren over de impact van de media-industrie op de live performance, hebben we ons vandaag te verhouden tot volledig gedemocratiseerde en betaalbare middelen als second screens, mobiele telefoons, live streaming video, tablets, steeds 
goedkopere computerrekensnelheid, minicamera's en diverse connectiviteits-apps. Dit zijn allemaal middelen die ook zeer wel ingezet kunnen worden door subversieve, autonome en authentieke kunstenaars. ${ }^{28}$

Lehmann schetste een radicaal nieuwe theateresthetische omgang met begrippen als tijd, ruimte, lichamelijkheid en tekstbehandeling. Anderen hebben na hem, zoals gezegd, studie gemaakt van elementen uit dit nieuwe theateridioom. In hoofdstuk 2 , waarin ik een theoretisch kader voor deze studie schets, ga ik dieper in op deze doorontwikkeling van centrale concepten uit Lehmanns studie en het belang ervan voor de huidige transformaties in het contemporaine theater. Mijn casestudies tonen in welke mate na anderhalf decennium Lehmanns noties over de stand der dingen in het westers theater aan het eind van de twintigste eeuw hun weg hebben gevonden naar constituerende instituties van het Nederlandse en Vlaamse theater anno nu. Ik zet in die hoofdstukken een aantal van de centrale concepten van zijn herijking van de theateresthetiek naast hedendaagse intermediale, interculturele en internationale cultureel dynamische ontwikkelingen.

${ }^{28}$ Ik kom hierop terug in hoofdstuk 3 bij de casestudie over Toneelhuis Antwerpen. 


\section{Hoofdstuk 2 Theoretisch kader}

'Hoeveel soorten zinnen zijn er echter? Bewering, vraag en bevel misschien? Er zijn talloze soorten: talloze verschillende manieren om dat te gebruiken wat wij "tekens", "woorden", "zinnen" noemen. En deze verscheidenheid ligt niet vast, is niet eens en voor altijd gegeven; nieuwe typen taal, nieuwe taalspelen, zouden we kunnen zeggen, ontstaan, en andere verouderen en worden vergeten' (Wittgenstein, 2002, p. 47).

\subsection{Inleiding}

Het theater is altijd een vergaarbak geweest van verschillende disciplines en tekensystemen (taal, vormgeving, muziek, belichting, architectuur) maar desondanks wordt het veelal gezien als een gekaderd kunstendomein. In de westerse literair dramatische theatertraditie is sinds de Grieken in de vijfde en de vierde eeuw voor Christus vooral de gesproken en geschreven taal het medium waarmee de tragedie en de komedie vorm kregen. Toneelteksten vormden de kern van het dominante canonieke theatersysteem. In het theater vocht de regisseur zich als creator, als kunstenaar met een eigen engagement en een eigen vormopvatting, pas eind negentiende eeuw binnen in het productieproces van het theaterkunstwerk. Hetzelfde gold voor de aanvankelijk vooral aan de tekst dienstbare uitvoerders van theatervormgeving, decorbouw, kostuumontwerp en later in de twintigste eeuw voor de inbreng van dans, muziek, belichting, beeldprojectie en ICT-toepassingen. Het op tekst gebaseerde theatersysteem heeft onder invloed van dit continue proces van 'vechten tegen indringers' steeds andersoortig idioom naast zich moeten dulden. Sinds de laatste decennia van de twintigste eeuw vinden er interferenties plaats tussen wat men metaforisch een aantal performatieve talen zou kunnen noemen, zowel in het centrum als in de periferie van het systeem als ook tussen centrum en periferie. In het hedendaagse theater is sprake van wat Lehmann parataxis noemt, dramaturgie van de nevenschikking. Het betekent dat de dominantie van taal in het theater afneemt ten gunste van hybride mengvormen van podium- en andere kunsten. Tegelijkertijd ontstaat er een netwerk van uitwisselingsprocessen tussen het traditionele theater en een grote verscheidenheid aan andere artistiek performatieve uitingen van buiten het 
traditionele theaterdomein, waarmee het gevestigde theater zijn dominante positie lijkt te verliezen. Een van mijn collega's op de Toneelacademie in Maastricht, cultuurfilosoof Frank Mineur, formuleerde een essentiële vraag bij deze constatering: 'Is dat erg?' Het antwoord op deze vraag hangt af van iemands wereldbeeld. Als men ervan uitgaat dat de theatertraditie op dit moment nog deel is van een canonieke centrumcultuur, op te vatten als een hoofdmacht die dominant moet blijven met hooguit hier en daar enige extensies in de periferie, dan is het erg omdat een dominant centrum als richtpunt zou kunnen verdwijnen in een verzameling subculturen. Als men daarentegen uitgaat van een veranderende wereld waarin steeds vaker sprake is van inter (internationaal, intermediaal, interdisciplinair, intercultureel, intersectoraal), dan is het veel minder erg. Dan is er het beeld van een wereld die geordend wordt in formele en informele netwerken waarin veel wat anders is dan wij zelf zijn, is opgenomen. 'Wij' zijn dan de oorspronkelijke Nederlanders, wij van de theatertraditie, wij van een talige theatercultuur. In een dergelijk wereldbeeld is er een gelijkwaardige rol voor die anderen en het andere. Binnen de wetenschapsfilosofie, de sociale wetenschappen en de geesteswetenschappen heeft dit denken in netwerken de laatste decennia een grote vlucht genomen.

Mijn onderzoek naar transformaties in het theaterlandschap ontvouwde zich rond het besef dat geïnstitutionaliseerde cultuurdomeinen als het theater beschouwd kunnen worden als systemen met een centrum en een periferie, waarbij de verhouding tussen die twee beweeglijk is. Zelf nam ik kennis van deze manier van denken over aan elkaar gerelateerde, interacterende cultuursystemen via het werk over polysystemen van de Israëlische literatuurwetenschapper Itamar Even-Zohar, dat ik aantrof in de studie naar heterogeniteit van de Nederlandse literatuur in de jaren tachtig door literatuurwetenschapper Maaike Meijer. Zo beschouw ik in dit onderzoek het theatersysteem als een samenhang tussen in de loop der tijd gevormde theaterinstituties die in hun gezamenlijkheid gezien kunnen worden als 'Het Theater'. Het netwerk van het artistiek performatieve lijkt zich echter in de huidige cultureel dynamische context veel verder uit te strekken. Door onder anderen Schechner, Lehmann, Fischer-Lichte en Chapple \& Kattenbelt zijn er in de afgelopen decennia allerlei relaties blootgelegd tussen centrum en periferie van het bestaande theatersysteem, tussen theater en andere kunsten, en tussen theater en domeinen die niet direct tot de kunsten gerekend werden. De laatste decennia hebben wetenschappers vanuit diverse disciplines getracht deze ontwikkelingen te analyseren. Een aantal centrale concepten is daarbij prominent geworden. Hierna zal ik in paragraaf 2.2 aandacht schenken aan de meest richtinggevende centrale concepten in dit discours, namelijk drama, tekst, theater, theatraliteit, performance, performatief, performativiteit en intermedialiteit. In paragraaf 2.3 bespreek ik het werk van de relationele denkers Itamar Even-Zohar, Gilles Deleuze en Bruno Latour. Bij hen vond ik 
de terminologie om de huidige toestand van het theater te kunnen benaderen. In paragraaf 2.4 beschrijf ik de methodologische consequenties van de positie die ik als onderzoeker had, tegelijkertijd werkend als docent aan een theateropleiding (reflective practitioner). Bij de Britse theaterwetenschapper en expert op het gebied van intermedial performance, Robin Nelson, vond ik de noodzakelijke formuleringen om deze met de theaterpraktijk verknoopte manier van werken te kunnen vertalen in een specifieke onderzoeksaanpak.

\subsection{Conceptuele analyse}

\section{Drama en tekst}

Spreken over postdramatisch theater en over het discours na de introductie van het begrip is spreken over drama in relatie tot tekst. Het adjectief postdramatisch benoemt een theater dat opereert voorbij het drama, in een tijd na de geldigheid van het dramaparadigma. Lehmann heeft de belangrijkste vernieuwingen die het westers theater na de jaren tachtig van de vorige eeuw hebben gekenmerkt in kaart gebracht, zo wordt algemeen aanvaard. Tegelijkertijd stellen Swyzen en Vanhoutte in de inleiding van Het statuut van de tekst in het postdramatisch theater (2011) de vraag of in het discours na Lehmann niet te snel en te generaliserend het belang van de tekst is ingeruild voor een meer dominant geachte rol van het beeld. 'Na het drama' wil voor zowel Lehmann zelf als voor veel verdedigers van het blijvende belang van tekst zeggen dat tekst als structuur voor wat theater is, nog wel degelijk voortleeft (Lehmann, 1999, p. 30; Swyzen \& Vanhoutte, 2011, p. 12). Tekst is daarbij op te vatten als een samenhangend geheel van taal. Taal is de combinatie van letters die betekenisdragende woorden kunnen vormen, woorden die betekenisdragende zinnen vormen binnen een bestek van de regels van de grammatica. Taal biedt de mogelijkheid tot betekenisvol uitdrukken in geschreven en gesproken vorm. Het postdramatische theater opereert nog steeds in een voor een belangrijk deel tekstgestuurd theaterdomein, maar het maakt theatervormen mogelijk met andere accenten en andere manieren van gebruik van tekst en taal. Lehmann onderscheidt drie niveaus van tekst in het postdramatische theater: ten eerste de linguïstische tekst, dat is de tekst in engere zin, die uit taal bestaat; ten tweede de voorstellingstekst in de zin van alle tekensystemen die samen het begrip voorstelling vormgeven, en ten derde de performancetekst. Het laatste niveau wordt in de performance studies ook wel opgevat als de totale situatie van de performance: de aard van de voorstelling zelf, de relatie tussen performer en toeschouwer, de positie van theater in het sociale veld, de tijdelijkheid van de gebeurtenis, de aard van het theatergebouw. De performancetekst 
zal volgens Lehmann over het algemeen de andere twee tekstniveaus 'overdetermineren' (Lehmann, 1999, p. 145).

Lehmann verwijst voor een beter begrip van de hedendaagse relatie tussen drama, tekst en theater naar de Aristotelische begrippen logos, opsis en telos. Vanaf het klassieke theater kan drama opgevat worden als logocentrisch, waarbij logos allereerst verwijst naar tekst in engere zin. Tevens staat logos voor een mix van orde, logica, oorzakelijkheid, oorsprong en vaderbeeld (Lehmann, 2011, p. 29). Het begrip opsis staat voor schouwspel, dat wat getoond wordt aan het publiek. Het staat in de logocentrische traditie voor de mogelijkheden tot verwarring, tot vermenging van structuren, zelfs tot de afwezigheid van elke rationele structuur (Lehmann, 2011, pp. 27-37). Het begrip telos staat voor een hiërarchisch geordende architectuur van betekenis, voor een doel, voor causale logica. Er is geen logos (in de ruimere betekenis van orde en oorzakelijkheid) zonder telos in de Aristotelische traditie. Lehmann maakt in zijn artikel 'From Logos to Landscape' duidelijk dat we ongeveer vanaf 1970 in het westerse theater te maken hebben met de herontdekking van opsis, dat wil zeggen dat er vanaf die tijd ruimte voor het schouwspel zonder telos ontstaat, zonder hiërarchisch gestructureerde betekenis, zonder causale logica of innerlijke samenhang (Lehmann, 1997, pp. 55-60). Of zoals hij letterlijk stelt: 'Het lijkt erop dat het theater in de loop van deze paar decennia noch een volledige teloorgang van het woord heeft gekend, noch een plotse herintroductie van tekst. Veeleer hebben zich langs ingewikkelde en kronkelende paden nieuwe visies op een meervoudige logos en een nieuwe vorm van architectuur ontwikkeld- een architectuur van het theater. Sindsdien zoekt en ontwerpt theater ruimten en discoursen die zo veel mogelijk zijn bevrijd van de beperkingen van een doel (telos), hiërarchie en causale logica' (Lehmann, 1997).

\section{Drama, theater en theatraliteit}

Het begrip theater heeft vele betekenissen en connotaties. Het verwijst naar het dramatische genre, naar de opvoering als een schouwspel, naar repertoire of naar een gebouw. Als we in Nederland zeggen dat we 'naar het theater' gaan, zal het gros van de mensen denken dat we naar een stadsschouwburg gaan, naar een bekend theatergebouw in de eigen stad, naar een landelijk bekend theater (De La Mar) of een vlakkevloerzaal (Frascati, Toneelschuur Haarlem). Het is bij een dergelijke mededeling in de eerste instantie onduidelijk of dan een gesubsidieerd canoniek toneelstuk bezocht wordt, een dansvoorstelling, cabaret, een commercieel geproduceerde komedie, een lokale versie van de Voice of Holland of een musical. Het is op basis van deze enkele mededeling allemaal mogelijk. Theater is een containerbegrip geworden. In Groot-Brittannië heb ik op een theaterschool horen spreken over the industry, als één groot werkveld voor podiumkunstenaars van de Royal Shakespeare Company, 
voor kunstenaars op het kleurrijke palet van de fringe sector ${ }^{29}$, via de musicals op West End tot en met de wereld van film en televisie.

Net als theater is drama ook een begrip met veel betekenissen en connotaties. Als we over drama spreken gaat het in onze tijd vaak om een verhaal in een theatrale vorm. De term wordt echter ook gebruikt voor een genre in de filmwereld. Hij duidt daar op een verhaal met een begin, midden en een eind, over het algemeen met een oorzaak-gevolgstructuur. Het mag dan gebaseerd zijn op waargebeurde belevenissen, het wordt vaak gebracht als fictief; het gaat om een andere wereld dan die van de toeschouwer, maar die dient zich wel goed te kunnen identificeren met de personages. Van een heel andere orde is een uitroep als: 'Het was een drama.' Hiermee wordt bedoeld dat er iets plaatsvond wat opwinding veroorzaakte of verdriet losmaakte. Er kan ook sprake zijn van een ironische connotatie. Lehmann geeft het voorbeeld van een moeder die uitroept: 'Dat was me toch een drama!'. De moeder gaf commentaar op het huilen van haar kind, dat teleurgesteld was omdat het niet naar de bioscoop mocht (Lehmann, 2006, p. 35).

Drama betekent in het Grieks handeling. De handeling in het Griekse drama bestond vooral uit het door middel van tekst imiterend vormgeven van menselijk handelen en de motieven die eraan ten grondslag liggen. Alles waarmee dat gedaan werd, was aanvankelijk ondergeschikt aan het primaat van de tekst. De term drama (literair genre, gesloten handeling, fictieve wereld, logocentrische categorie) was lang synoniem voor theater (vormgegeven handeling, gebeurtenis voor toeschouwers, samengaan van handeling, muziek, beeld en vormgeving) en was bepalend voor wat in de kern onder theater werd verstaan: een illusie, een gesloten fictieve werkelijkheid. Bij Lehmann (1999) kunnen we lezen dat deze verbondenheid van drama met theater in de loop van de ontwikkeling van het moderne theater langzaam maar zeker losser werd, waarna de begrippen tenslotte van elkaar vervreemdden. Het karakter van drama lag vooral besloten in het primaat van de tekst, het karakter van theater als spektakel zat vooral in de toenemende vrijheid bij het kiezen van theatrale middelen.

Lehmann voert Peter Szondi op als degene die in zijn Theorie des modernen Dramas (Szondi, 1956) het epische theater beschrijft als mogelijk twintigste-eeuws universeel alternatief gereedschap voor het vormgeven van een fictieve wereld. Lehmann vraagt zich af of dit wel werkelijk een alternatief is. Vanaf het eind van de twintigste eeuw bestaat er simpelweg theater met en theater zonder drama. Het is wellicht vanwege deze dubbelheid dat ondanks het feit dat hedendaags theater zichzelf profileert als een verzamelplaats van diverse kunstendisciplines, het traditionele theaterpubliek nog steeds problemen heeft met postdramatisch theater.

\footnotetext{
${ }^{29}$ Het Engelse begrip fringe (franje, zoom, rand, periferie, marge) staat in de Angelsaksische theaterwereld voor vaak kleinschalig (onderzoeks) theater aan de rand, in de periferie van de dominante mainstream podiumkunsten. Een van de grootste fringe festivals ter wereld is het jaarlijkse Edinburgh Theatre Festival.
} 
Het postdramatische theater exploreert een palet aan werkwijzen, materialen en verschijningsvormen, terwijl drama, gebaseerd op gesloten fictie met heldere verhaallijnen inclusief de mogelijkheden tot identificatie, nog steeds een veelvoorkomende structurerend principe is in bijvoorbeeld films, televisieseries, in de musicalwereld en niet te vergeten in het amateurtheater.

“Das Drama, exemplarische Form der Diskussion, setzt auf Tempo, Dialektik, Debatte und Lösung. Aber schon lange lügt das Drama. Sein Geist, besser: sein Gespenst, ist aus dem Theater ins Kino, zunehmend ins Fernsehen gewandert. Da sind die Möglichkeiten der Simulation von Wirklichem viel größer, da zählt die Story, schon deshalb, weil nichts in seinem Widerspruch, nichts in seiner Spaltung und Verdopplung, nichts in seiner Fremdheit wahrzunehmen erlaubt, kommt man vom V-effect zum TV-effect“" (Lehmann, 1999, p.126).

Drama vormgeven als gesloten fictie betekent aandacht schenken aan datgene wat die fictie vormgeeft naast de tekst, het Aristotelische opsis zouden we kunnen zeggen. In het canonieke dramatische repertoire in het westers theater is die fictie vooral verpakt in de overgeleverde tekst. In het moderne westerse theater vanaf rond 1880, wordt de fictieve wereld zo geloofwaardig mogelijk vormgegeven door theatrale middelen als inventieve verlichting, vormgeving en decorbouw, realistisch ogende rekwisieten en realistische speelstijlen, gericht op de geloofwaardigheid van menselijke personages, inclusief hun motieven om te handelen. Terwijl de film in het tijdperk van het 'apparatenparadigma' steeds meer de functie van theater als dramatische kunst heeft overgenomen (Chapple \& Kattenbelt, 2006, p. 29), werd het sinds de jaren zestig usance om in het theater meer onderzoeksmatig en abstract om te gaan met opsis en telos. ${ }^{30}$ Dit verschil tussen theaterkunst en de entertainmentwereld is voor een groot deel van het publiek verwarrend. Omdat het herkenbare drama grotendeels verschoven is naar de film, de televisie en de wereld van het entertainment, verwacht het publiek deze zelfde fictieve werelden aan te treffen in het meer kunstzinnige theater. Daar heeft zich echter een transformatie voltrokken, met als resultaat een grote mate van abstractie en een vervreemding tussen herkenbaar drama en exploratief theater. Fischer-Lichte spreekt in Ästhetik des Performativen over een groot "Forschungslabor" (Fischer-Lichte, 2004, p. 128).

De begrippen theatraliteit en theatraal verwijzen naar eigenschappen die de elementen die een fictieve wereld vormgeven in een opvoering van een tekst kunnen hebben. Charlotte De Somviele verwijst naar Roland Barthes en Patrice Pavis, die

\footnotetext{
${ }^{30}$ Chapple \& Kattenbelt betreuren dat in het zelfde artikel geenszins, ze concluderen wel dat het daardoor noodzakelijk lijkt om het theater te herdefiniëren: niet meer als samengestelde kunst of als dramatische kunst, maar als het podium van de intermedialiteit.
} 
beiden schreven dat theatraliteit zowel kon verwijzen naar bepaalde aspecten van de tekst (opvoerbaarheid) als naar het geheel van buitentekstuele tekens en sensaties (belichting, vormgeving, kostumering) (De Somviele, 2011, pp. 193-208). Daar waar in hedendaags theater minder sprake is van fictie maar meer van een realiteit die toeschouwers en performers met elkaar delen, spreken we eerder van performances en van begrippen die hiervan afgeleid zijn.

\section{Performance, performatief en performativiteit}

Hedendaagse artistieke praktijken tonen een grote diversiteit aan ensceneringsvormen, thematiek, gereedschappen, kennisdomeinen, werkwijzen, vakgebieden en beroepsgroepen. De verschillende cultuuruitingen zouden we in hun samenhang kunnen zien als een spectrum van in elkaar overlopende mengvarianten, geordend op grond van een aantal 'basiskleuren' (Chapple \& Kattenbelt, 2006, p. 27). Bij het zoeken naar een noemer voor deze verzameling vallen regelmatig de termen performance, performatief en performativiteit. De term performance is in de afgelopen decennia populair geworden in verschillende disciplines, van podiumkunsten en literatuurfilosofie tot en met de sociale wetenschappen. Over het begrip bestaat veel verwarring (Carlson, 2003; Salter, 2010) en dat geldt ook voor de ervan afgeleide termen performatief en performativiteit. Voor een algemene definitie van het performancebegrip verwijst de grondlegger van de performance studies Richard Schechner naar de socioloog Erving Goffman: "A 'performance' may be defined as all the activity of a given participant on a given occasion which serves to influence in any way any of the other participants." (Schechner, 2002b, p. 23). Meer recent onderscheidt mediakunstenaar en wetenschapper Chris Salter in Entangled: Technology and the Transformation of Performance (2010) drie domeinen waarbinnen de begrippen performance en performativiteit de afgelopen zestig jaar zijn gebruikt: in de cultuurwetenschappen, in de taalfilosofie en in de wetenschap- en technologiestudies.

Binnen het culturele domein onderscheidt hij performance allereerst als genre in de beeldende kunst vanaf de jaren vijftig, gekenmerkt door live acties en happenings. Daarnaast beschrijft hij hoe binnen hetzelfde cultuurdomein Schechner, Goffman en ook antropoloog Clifford Geertz, ieder in hun eigen vakgebied het begrip aanwendden in andere dan in strikt artistieke contexten. Geertz onderzocht dagelijkse gebruiken van verschillende volkeren als vormen van cultureel scheppend handelen (Geertz, 1973); Schechner verhelderde overeenkomsten en verschillen tussen theatrale- en performatieve uitingen in westerse en niet-westerse culturen, legde ook een verband met performatieve situaties in het dagelijks leven (reclame, sport, sex, kunst) en sprak daarbij van herhalingspatronen, van restored behaviour (Schechner, 2002b, p. 28). 
Goffman werd bekend van studies naar de symboliek van aangeleerd alledaags gedrag (framing en role playing). Alle drie hanteren ze dus een veel ruimer performancebegrip dan bekend was uit de avant-garde kunst.

Vervolgens beschrijft Salter hoe naast deze cultuurwetenschappelijke benadering vanaf het midden van de jaren vijftig in de taalfilosofie de speech-act theory werd ontwikkeld door de Britse linguïst John L. Austin, die de term performatief muntte in zijn How to Do Things with Words (1955). Performatief verwijst bij Austin naar de eigenschap van een werkwoord dat een handeling aanduidt die door het uitspreken van het werkwoord meteen ook plaatsvindt: 'Hierbij verklaar ik u gehuwd', of 'Ik waarschuw u'. Bij het uitspreken doet het woord wat het zegt. Het begrip performatief werd later in dit verband toegepast op genderkwesties door filosoof en cultuurwetenschapper Judith Butler. Zij ziet door gender gecodeerde taal en gedrag niet zozeer als gevolg van een vooraf gegeven gendersysteem maar als de oorzaak ervan.

Tot slot brengt Salter de termen performance en performativiteit in verband met de pogingen van wetenschaps- en technologiefilosofen Bruno Latour, Michel Callon en John Law om de betekenisgenererende rol van materiaal en van objecten te begrijpen. Of zoals Salter schrijft:

"... those working in Science and Technology Studies (STS) have effectively displaced humans as the sole producers of knowledge, the expressers of agency, or the only performers worthy of study in scientific dramas" (Salter, 2010, p. xxvii).

In deze studie gebruik ik de term performance in de zin van vertoning, van op- of uitvoering, en performatief als het hiervan afgeleide adjectief. Performance verwijst hier niet alleen naar toneeluitvoeringen in engere zin, maar naar een veel breder terrein van vormen van bewuste artistieke enscenering ten behoeve van een groot of klein publiek. In hun inleiding van de bundel Performance and performativity (1995) formuleren Andrew Parker en Eve Kosofsky Sedgwick het als volgt: "...in the vicinity of the stage, however, the performative is the theatrical" (Parker \& Kosofski Sedgwick, 1995, p. 2). Ik ben me ervan bewust dat er wetenschappers en podiumkunstenaars zijn die een smallere definiëring van performance hanteren, als het uitvoerende optreden voor een live aanwezig publiek. Bij het beschouwen van hedendaags theater worden echter sterke intermediale verbanden waargenomen (Chapple \& Kattenbelt, 2006). Een bredere definiëring geeft rekenschap van de complexe relaties tussen het theatrale (het kunstmatig representerende), het performatieve (het presenterende) en media als cinema, televisie, digitale media, streaming video en mobiele telefonie. Parker en Kosofsky Sedgwick formuleerden deze interacties als volgt: 
"Re-imaging itself over the course of the past decade as the wider field of performance studies, the discipline has moved well beyond the classical ontology of the black box model to embrace a myriad of performance practices, ranging from stage to festival and everything in between: film, photography, television, computer simulation, music, 'performance art', political demonstrations, health care, cooking, fashion, shamanistic ritual" (Parker \& Kosofsky Sedgwick, 1995, p.2).

Met mijn gebruik van het adjectief performatief sluit ik aan bij deze brede definiëring van het performancedomein, met dien verstande dat ik me voor deze studie zal beperken tot performatieve uitingen in artistieke domeinen. Mijn aanpak is minder breed antropologisch dan die van Schechner en niet taal- en cultuurfilosofisch als die van Austin en Butler. Binnen wat ik een performatief spectrum noem, is sprake van verschillende soorten artistiek performatieve uitingen, alle gekenmerkt door ensceneringaspecten. Het performatieve spectrum is in mijn ogen op een vergelijkbare manier te lezen als de performancetekst waar Lehmann over spreekt in verband met het begrip theateropvoering (Lehmann, 1999, p. 145). Beide begrippen geven aan dat door meer factoren betekenis wordt gegenereerd dan alleen door de esthetische, maar de concrete reikwijdte ervan verschilt. In het huidige hybride theater-, performance- en medialandschap overstijgt het performatief spectrum de theater- en kunstkaders en heeft daarmee een groter maatschappelijk bereik dan Lehmanns op de theateropvoering betrekking hebbende performancetekst.

Met deze benadering sluit ik mij deels aan bij Fischer-Lichte. Zij beschrijft in Ästhetik des Performativen (2004) de performative turn van de jaren negentig, waarmee de grenzen tussen diverse kunstdisciplines werden opgeheven waar het ging om de verhouding tussen subject en object, en tussen materialiteit (Materialhaftigkeit) en lichamelijkheid (Körperhaftigkeit). De verhouding tussen performers en toeschouwers veranderde, presentatie en zelfreferentialiteit werden belangrijker dan (canonieke) representatie en een opvoering werd volgens Fischer-Lichte in plaats van een op zichzelf staand kunstwerk met een betekenis een gezamenlijk door producenten en toeschouwers geconcipieerde gebeurtenis. Toeschouwers werden steeds minder geacht om de in een bepaald format gegoten betekenis te decoderen, maar om deel te nemen aan een gezamenlijk te beleven ervaring (Fischer-Lichte, 2004, p. 29). Volgens Fischer-Lichte maken interpretatie en betekenis (semiotiek) in de loop der tijd plaats voor de onmiddellijke ervaring (fenomenologie). Door deze bevindingen achtte Fischer-Lichte het onontkoombaar om een nieuwe esthetiek te ontwikkelen, een esthetiek van het performatieve, waarbij ze net als Lehmann lijkt vast te houden aan de kunsten als een specifieke centrale categorie.

Door mijn vermoeden dat de performatieve samenhang van esthetische uitingen breder te beschouwen is dan alleen binnen de kunsten, ben ik het eens met Kattenbelt 
die in "Intermediality in Performance and as a Mode of Performativity" (2010) stelling neemt tegen Fischer-Lichtes opvatting dat door de performative turn de semiotiek plaats zou moeten maken voor de fenomenologie als benaderingswijze van hedendaagse esthetische uitingen, alsof betekenis en ervaring niet samen zouden kunnen gaan. Kattenbelt zegt dat als volgt: "I propose that signification (semiotics) and experience (phenomenology) are imbricated within each other in the contemporary 'performative culture', not separable in a historical sequence, as suggested by FischerLichte" (Kattenbelt, 2010, p. 29). Hij verwijst naar auteurs als Debord, Kershaw, Eco, Pine \& Gilmore en McKenzie, die in de afgelopen decennia al verwezen naar bredere gebieden in de hedendaagse samenleving waar het begrip performance een steeds grotere betekenis kreeg, door hen ook uitdrukkelijk opgevat als betekenisvolle gebeurtenis (Kattenbelt, 2010, p. 34). Volgens Kattenbelt komt de performative turn niet alleen voort uit een aantal opmerkelijke evoluties in de kunstendisciplines, maar ook voor een belangrijk deel uit de allesomvattende mediatisering van de samenleving door de massamedia in de loop van de twintigste eeuw, exponentieel versterkt door de explosieve digitale revolutie van de laatste decennia. In deze ontwikkeling is het onderscheid tussen object en subject, tussen kunstwerk en ervaring, tussen performer en toeschouwer, tussen lichaam en materialiteit verder vervaagd.

\subsection{Theorie en methode: het denken in netwerken}

\section{Even-Zohars polysysteemtheorie}

De Israëlische literatuurwetenschapper Itamar Even-Zohar heeft vanaf het begin van de jaren zeventig gewerkt aan de ontwikkeling van zijn polysysteemtheorie. Hij startte als linguïst en ontwikkelde de eerste blauwdrukken nog hoofdzakelijk binnen de taalkunde. Zijn doel was de dynamische samenhang van verschillende talen en later van verschillende culturele systemen te begrijpen (Even-Zohar, 1978/2005). Hij analyseerde wat er gebeurde als twee of meer talen op elkaar botsten of zich in één gemeenschap langzaam maar zeker met elkaar vermengden. Hij beschreef processen van interferentie, de manier waarop woorden, zinsconstructies, klankaspecten en onderdelen van het idioom van de ene taal overgenomen werden door de andere en vice versa. Hij onderzocht deze processen in de loop van de jaren zeventig en tachtig in het Midden-Oosten, in India en in Europa, waarbij hij ervan uitging dat taal niet alleen een voertuig voor communicatie en interactie is maar ook voor symbolische waardebepaling; taal is naast praktisch communicatiegereedschap ook identiteitsvormend. Zijn project omvatte gevalstudies van interferenties tussen het Hindi versus het Urdu, Hebreeuws versus Jiddisch, het Noorse Riksmål versus Landsmål, het Hoog Duits en het Beiers, Frans en Patois, Servisch versus Kroatisch, 
Spaans en Guaraní, en Deens en Jutlands. Met latere versies van de polysysteemtheorie wierp hij het net nog breder uit en leverde hij een methode om de complexiteit en de onderlinge verbondenheid van culturele systemen te analyseren. Even-Zohar zag deze complexe betekenissystemen per definitie als verzamelingen van heterogene en dynamische netwerken van relaties.

Hij startte zijn onderzoek binnen de literatuurwetenschap vanuit een kritische houding ten aanzien van het werk van de Zwitserse structuralistische taalkundige Ferdinand De Saussure (1857-1913), die wordt beschouwd als de grondlegger van de moderne linguïstische semiotiek. Geluiden, plaatjes, geschreven woorden, schilderijen, foto's, etc. functioneerden bij De Saussure als tekens van 'talen' waarmee in door conventies gereguleerde systemen gecommuniceerd kon worden. Communicatie was voor hem het uitdrukken of uitwisselen van ideeën, waarbij elk teken (signe) bestaat uit twee deelelementen: het eerste element is de betekenisdrager (signifiant, het woord of de afbeelding) en het tweede is het betekende (signifié, het concept in ons hoofd van wat het woord of de afbeelding aanduidt). Dit teken in zijn geheel (woord + concept) verwijst volgens De Saussure naar een bestaand object, het ding of de persoon in de werkelijkheid (Hall, 1997, pp. 13-74). ${ }^{31}$

Voorts verdeelde hij de concrete werking van taal in twee delen. Een deel (/a langue) bestaat uit dieperliggende codes en regels van een taalsysteem, die door alle gebruikers van die taal gedeeld worden. Het tweede deel (la parole) bestaat uit de particuliere manier waarop individuele gebruikers zich in hun specifieke manier van spreken of schrijven bedienen van die taalcodes en regels; hij beschouwde dit als de oppervlakte van de taal. De Saussure heeft zich hoofdzakelijk met het eerste deel, de dieper liggende structuur van taalcodes en regels, beziggehouden. Hij noemde dit ook wel het sociale deel van het taalsysteem, dat volgens hem bestudeerd konden worden met een wetenschappelijk wetmatige precisie.

In de taalwetenschap en de semiotiek is nagenoeg iedereen schatplichtig aan het werk van De Saussure. Sinds de tweede helft van de twintigste eeuw is er ruimte gekomen om enige afstand te nemen van zijn statische, structuralistische benadering en wordt er op een lossere manier omgesprongen met zijn model. Door de manier waarop Even-Zohar in zijn Papers in Culture Research (1978/2005) ruimte gaf aan reflecties over cultural goods, over degenen die ze bezitten of zich er van bedienen en over de manier waarop ze van waarde en maatschappelijk belang kunnen veranderen, past zijn theorie in de laat twintigste-eeuwse poststructuralistische traditie waarin veel geesteswetenschappers het genereren van betekenis zien als resultaat van dynamische discoursen in plaats van als hoofdzakelijk gebaseerd op vastliggende onderliggende taalcodes (Even-Zohar, 1978/2005, pp. 8-9).

\footnotetext{
${ }^{31}$ Stuart Hall geeft het voorbeeld van het woord of de afbeelding van een walkman, in beide gevallen wordt verwezen naar het concept in ons hoofd van een in de jaren tachtig populaire draagbare cassettespeler.
} 
Even-Zohar heeft er met de polysysteemtheorie naar gestreefd om de voor structuralisten strikt univalente causale parameters te vervangen door polyvalente factoren om de complexiteit van taal- en cultuursystemen te verklaren. Zowel binnen de grenzen van één cultureel systeem als in grensgebieden tussen culturele systemen is volgens Even-Zohar sprake van meervoudig samengestelde dynamische systemen. $\mathrm{Hij}$ ging ervan uit dat in ieder systeem sprake is van een centrum en een periferie en dat er altijd gelijktijdig een centrifugale én een centripetale kracht werkzaam is. Zo stel ik me in het kader van dit onderzoek voor dat het westerse teksttheater beschouwd kan worden als één cultureel systeem waarin theatermakers, acteurs, performers en andere podiumkunstenaars zich met hun werk verder af of dichterbij een dominant centrum van hun vak-biotoop bewegen. Dat de hoofdrolspelers in het centrum de nietstandaardvarianten vaak naar de periferie verwijzen valt samen met heersende ideologie, met de werking van instituties. ${ }^{32}$ Hierbij gaan zij uit van een kennersblik van ingewijden, van een inside view, zoals Even-Zohar zegt. In zijn polysysteem behoren de niet-standaardvarianten echter juist wezenlijk tot het systeem. Hij is niet mis te verstaan in de manier waarop hij dat voor een taalsysteem beargumenteert:

"This means that any isolatable section of culture may have to be studied in correlation with other sections in order to better understand its nature and function. For example, official culture requires studying non-official culture(s); standard language can better be accounted for by putting it into the context of the non-standard varieties; prestigious types of texts can be related to less prestigious ones, and so on" (Even-Zohar, 1978/2005, p. 41).

Als prestigious types gerelateerd dienen te worden aan de less prestigious ones om ze te kunnen begrijpen, dan kunnen we in verband met het Nederlandse theater wijzen op de wisselende relaties tussen bijvoorbeeld kleinkunst, volkstheater, ongesubsidieerd theater, urban theatre, intercultureel theater, cabaret, amateurtheater en community theatre aan de ene (minder prestigieuze) kant en het prestigieuze gevestigde, gesubsidieerde theater in al zijn varianten aan de andere kant. Even-Zohar spreekt zich overigens niet specifiek uit over de werking van zijn polysysteemtheorietheorie voor het theater. Ik doe dat met dit onderzoek wel. Daar waar Even-Zohar polysystemen aanwijst binnen omkaderde kunst- en cultuurdomeinen als de literatuur, de film, de taal, de poëzie, het theater, de mode, de popmuziek, de fotografie, vat ik de huidige artistieke praktijk op als een niet gekaderd

\footnotetext{
${ }^{32}$ Even-Zohar onderscheidt bij wat hij noemt socio-semiotic (cultural) events als een frame van instituties, de volgende constitutieve factoren en afhankelijkheden: instituties, repertoire, producenten, consumenten, markten en producten.
} 
netwerk dat ook buiten de geijkte kunstdomeinen performatieve aspecten met elkaar verbindt. $^{33}$

Even-Zohar noemt bewegingen van centrum naar periferie en omgekeerd conversies; bewegingen waarbij cultuursystemen elkaar beïnvloeden noemt hij interferenties. Hierbij is steeds sprake van source culture en van target culture en van processen die hij aanduidt als transfers. Er vindt een transfer plaats als een verschijnsel of idioomaspect vanuit het ene cultuursysteem opgenomen wordt in het repertoire van een ander cultuursysteem, dus als de fase van beïnvloeding overgegaan is in een fase van acceptatie. Vervolgens is er sprake van nieuwe interferenties, een nieuwe transfer wordt voorbereid, vindt uiteindelijk plaats en het repertoire is wederom uitgebreid. Zo is er een voortdurende dynamische loop: interferentie $\rightarrow$ transfer $\rightarrow$ nieuw repertoire $\rightarrow$ interferentie $\rightarrow$ transfer $\rightarrow$ nieuw repertoire $\rightarrow$ interferentie etc.

Dit is te illustreren met een voorbeeld uit de historische relatie tussen theater en film. Als het concept montage vanuit het industriële begrippenapparaat van de negentiende eeuw zich via theorieontwikkeling door cinematografen als Sergey Eisenstein (1898 - 1948) en David W. Griffith (1875 - 1948) nestelt in de filmkunst en vervolgens in de tweede helft van de twintigste eeuw opduikt als een van de dramaturgisch vernieuwende concepten in het theater, dan zou Even-Zohar de cinematografie de source culture noemen en het theater de target culture. ${ }^{34}$ Systemen op deze manier met elkaar verbindend, wordt langzaam maar zeker een sociaalcultureel fijnmazig 'zenuwstelsel' zichtbaar dat volgens hem zijn kracht en zijn werking vooral dankt aan juist dit soort dynamische onderlinge samenwerking en samenhang.

In de afgelopen dertig jaar heeft Even-Zohar zijn systeem meerdere malen aangepast aan nieuwe bevindingen. In 1978, 1979, 1990, 1997, 2005 en in 2010 heeft hij steeds herziene versies gepubliceerd, voor een groot deel via internet (Even-Zohar, $1978 / 2005)^{35}$. Aanvankelijk was de theorie toegespitst op taal- en literatuurwetenschap; uiteindelijk kwam hij uit bij het bestuderen van de manier waarop cultural entrepreneurs, makers of life en idea-makers hun werk doen in wat hij de cultural industry noemde (Even-Zohar, 1978/2005, p. 201). Dat het hierbij verder ging dan alleen taal, bewijzen bijvoorbeeld beschrijvingen van de tegenstelling tussen 'nieuw-Hebreeuws' en 'oud-Joods', waarbij het naast taal ook ging over de semiotische status van groene olijven, olijfolie, witte kaas en welkomstceremonies van Bedoeïenen (Even-Zohar, 1978/2005, pp. 140-160). Hij strekte zijn onderzoek uit tot de

\footnotetext{
33 "However, with a polysystem one must not think of center and one periphery, since several such positions are hypothesized. A move may take place, for instance, whereby a certain item (element, function) is transferred from the periphery of one system to the periphery of an adjacent system within the same polysystem, and then may or may not move on to the center of the latter" (Even-Zohar, 1978/2005, p. 42).

${ }^{34}$ Zie Eisenstein (1981).

${ }^{35}$ Voor deze studie heb ik hoofdzakelijk gebruik gemaakt van de digitale versie uit 2005.
} 
antropologie en betoogde dat interpersoonlijke modellen en alledaagse strategieën geanalyseerd dienden te worden omdat relaties tussen alledaagse patronen van communicatie inzichten opleveren in culturen.

Het door hem gehanteerde concept van systemen als object van studie bleek in linguïstische en culturele onderzoeksgebieden beter bruikbaar dan het voorheen gebruikelijke verzamelen van data. Belangrijk in deze benadering van culturele systemen is dat er niet meer a priori van kan worden uitgegaan dat uitsluitend de dominante cultuurverschijnselen van een bepaalde periode tot het te analyseren culturele systeem behoren. Maaike Meijer heeft het in haar studie naar de diversiteit van de Nederlandse literatuur in de jaren tachtig in gevallen van een niet langer vol te houden beperking over : '(...) comfortabele synchrone en homogene beschrijvingen van één arbitrair deel van het literaire systeem' (Meijer, 1988, pp. 335-336). In de praktijk wordt een cultuursysteem, bijvoorbeeld een theatersysteem, dat in een bepaald tijdvak tot het culturele centrum wordt gerekend, nogal gemakkelijk opgevat als de exclusieve officieel gevestigde (theater)cultuur. Het huidige artistiek performatief spectrum vormt zich echter als een specifiek polysysteem door vakrelaties tussen mensen die werkzaam zijn in verschillende culturele systemen en door het steeds frequenter uitwisselen van voorheen vakspecifiek idioom. Binnen één cultuursysteem kan het al snel gaan, maar daarnaast worden concepten vanuit de ene sector (source culture) gemakkelijk overgenomen door andere actoren (target cultures) binnen het domein van artistiek performatieve uitingen. Even-Zohar spreekt bij dit soort overnames van exchange of goods. Een paar voorbeelden uit de recente theatergeschiedenis tonen dit soort interferenties.

In de loop van de jaren tachtig en negentig van de vorige eeuw zien we in de danswereld, voorheen overwegend zuiver klassiek academisch, een vernieuwend bewegings- en scenografie-idioom ontstaan. Het bewegingsmateriaal wordt gewoner. Er worden choreografieën ontwikkeld waarin meer plaats is voor theatrale elementen als gewoon lopen en spreken, en realistische vormgevingsdetails als huisraad. Vooral de choreografie van Pina Bausch uit 1978, Café Müller door Tanztheater Wuppertal (thans Pina Bausch Tanztheater Wuppertal), heeft op dit punt geschiedenis geschreven, ook vanwege het feit dat Bausch er blijk van gaf niet meer alleen te willen werken met afgetrainde klassiek opgeleide dansers, maar vooral ook met overtuigende theaterpersoonlijkheden. Deze visie werd later gemeengoed in het werk van Anne Teresa De Keersmaeker, Meg Stuart, LaLaLa Human Steps, Ultima Vez, C. de la B, Sidi Larbi Cherkaoui, Kristel van Issums T.R.A.S.H., Nanine Linning en anderen. Er vond een gestage stroom van interferenties plaats tussen het theater (source) en de danswereld (target). 
In 1987 regisseerde Antoine Uitdehaag Vuur in de sneeuw ${ }^{36}$ bij het RO Theater ${ }^{37}$ in Rotterdam. Er werd gespeeld in een realistisch vormgegeven decor dat een Amerikaanse plattelandswoning voorstelde. Na de pauze zag het publiek hetzelfde decor als voor de pauze, maar dan gedraaid in een hoek van 90 graden, als was het vanuit een ander camerastandpunt. Hier vond een exchange of goods plaats tussen het ene culturele systeem en het andere. Het concept camerastandpunt kwam vanuit de filmwereld (source culture) en had zijn weg gevonden naar de wereld van het grotezalentoneel (target culture). We zijn nu meer dan vijfentwintig jaar verder en iedereen is er zich van bewust dat we in de westerse wereld in een gemediatiseerde biotoop leven. Zulke interferenties zijn organisch onderdeel geworden van een samenhangend spectrum van werkwijzen, repertoire, instrumentarium, beeldtaal en vakmanschap.

Pina Bausch sprak in de jaren zeventig al van collagetechnieken, het naast elkaar zetten van ogenschijnlijk verschillende onderdelen. Deze juxtapositie was een concept uit de beeldende kunst dat zijn weg vond naar allerlei vormen van esthetische vormgeving. In het theater, en vooral in het minder strikt aan taaltraditie gebonden Nederlands-Vlaamse theater, wordt dit montagetheater, dat uitgaat van een gefragmenteerde dramaturgie, bijna een opmaat voor de manier waarop we nu in een gedigitaliseerde cultuur naar reeksen beelden zijn gaan kijken. Resonerend met de juxtapositie in kunstwerken en film- en video-installaties in musea, met de montage uit de cinematografie en met de collagetechnieken uit de beeldende kunst, zijn deze constructieprincipes in het theater gemeengoed geworden (Chapple \& Kattenbelt, 2006). Dit soort van overnames is met Even-Zohars interferentietechniek goed te duiden. In het theater als targetculture komt het steeds meer voor dat er andere halffabricaten dan de canonieke literair dramatische teksten worden benut. Veel westers traditioneel tekstrepertoire wordt nog steeds opgevoerd, maar voorstellingen op basis van romans of van beeldendekunstidioom, of op basis van teksten die geconstrueerd zijn als muziekstukken, of voorstellingen zonder teksten, in elkaar gezet als een filmscript, als een scenario, of als een storyboard, zijn daarnaast even gebruikelijk geworden. Al deze overnames zijn te beschouwen als interferenties in Even-Zohars polysysteem. Interferenties van source richting target (en andersom) zijn in vele combinaties voorstelbaar: film $\leftarrow \rightarrow$ nieuwe media; theater $\leftarrow \rightarrow$ performance;

\footnotetext{
${ }^{36}$ Oorspronkelijk verschenen als toneeltekst, A Lie of the Mind (1985), van de Amerikaanse schrijver/acteur Sam Shepard.

${ }^{37}$ In deze periode werd de naam van het gezelschap geschreven met de hoofdletters $R$ en $O$, als 'RO Theater'. In de periode rond de eeuwwisseling werd de naam formeel geschreven met kleine letters $r$ en o, als 'ro theater'. Na 2006 werd de gezelschapsnaam 'Ro Theater'. In de rest van dit boek gebruik ik de spelling 'Ro Theater', ongeacht de periode waaraan wordt gerefereerd.
} 
blank, westers $\leftarrow \rightarrow$ allochtoon, niet-westers; gesubsidieerd $\leftarrow \rightarrow$ niet-gesubsidieerd, digitaal $\leftarrow \rightarrow$ analoog, 'hoge' cultuur $\leftarrow \rightarrow$ 'lage' cultuur, etc.

Bovengenoemde interdisciplinaire theatervormen zijn in mijn optiek op te vatten als heterogene delen van één en hetzelfde spectraal samenhangend performatief systeem. ${ }^{38}$ Om de invloeden van migratie, van technologie en van een globaliserende cultuurindustrie op dat systeem adequaat te kunnen duiden, is het noodzakelijk dat niet-officiële theatergenres, stijlen en werkmethoden in een context geplaatst worden samen met de officiële en institutioneel nog vaak dominante varianten. Het is bij het hanteren van de polysyteemhypothese bovendien van belang om waarde- en smaakoordelen als criteria voor een a priori selectie van studieobjecten te verwerpen. Of zoals Even-Zohar het zegt: "This kind of biased elitism cannot be compatible with cultural history just as general history can no longer be the life stories of kings and generals" (Even-Zohar, 1978/2005, p. 41).

Even-Zohars polysysteemtheorie vond zijn weg over de wereld, niet in de laatste plaats naar die gebieden waar sprake is van modernisering van samenlevingen, van migratiestromen gepaard gaande met culturele mengprocessen, met botsing en vermenging van talen, omdat er met name daar wordt gezocht naar strategieën in de lijn van 'weg van het ene' (Meijer, 1988, 316). Ze formuleerde in Lust tot lezen (1988) een dergelijke ontwikkeling voor het Nederlandse literaire systeem als volgt:

'Tegenover de mythe van de Ene literatuur doe ik- in samenhang met EvenZohars polysysteem hypothese - een heterogeniteitvoorstel. Het literaire systeem is pluriform. Het bestaat uit een veelheid van bewegende circuits. De teksten en de verwachtingshorizonnen van lezers verschillen per circuit. De niet-dominante circuits zijn 'tegenliteraturen'. (Meijer, 1988, p. 316).

Er is op systeemniveau een parallel te trekken tussen dat wat Meijer eind jaren tachtig schreef over de Nederlandse literatuur en ontwikkelingen in de Nederlandse theaterwereld van de afgelopen veertig jaar. Zij rekende in Lust tot lezen vooral af met het idee van één homogene en dominante Nederlandse literaire traditie en schetste een pluralistisch beeld van meerdere naast elkaar bestaande literaire circuits (Meijer, 1988, pp. 316-344). Op een vergelijkbare manier zouden we kunnen spreken van het langzaam verdwijnen van één homogene theaterwereld en het belangrijker worden van diverse naast elkaar bestaande performatieve deelsystemen. Daarbij lijkt sprake van een pluralisering en vernetwerking die zich uitstrekken over aanpalende gebieden zowel binnen als buiten de kunsten (Schechner, 2002b; Latour, 2005).

\footnotetext{
${ }^{38}$ Zie ook Kattenbelt (2006) die stelt dat het theater als hypermedium alle andere kunsten en media in zich op kan nemen.
} 


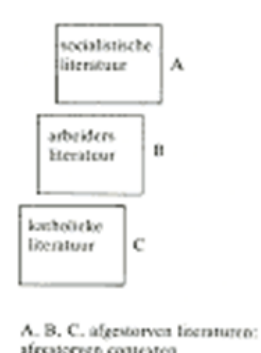
ifgosicress contesteo

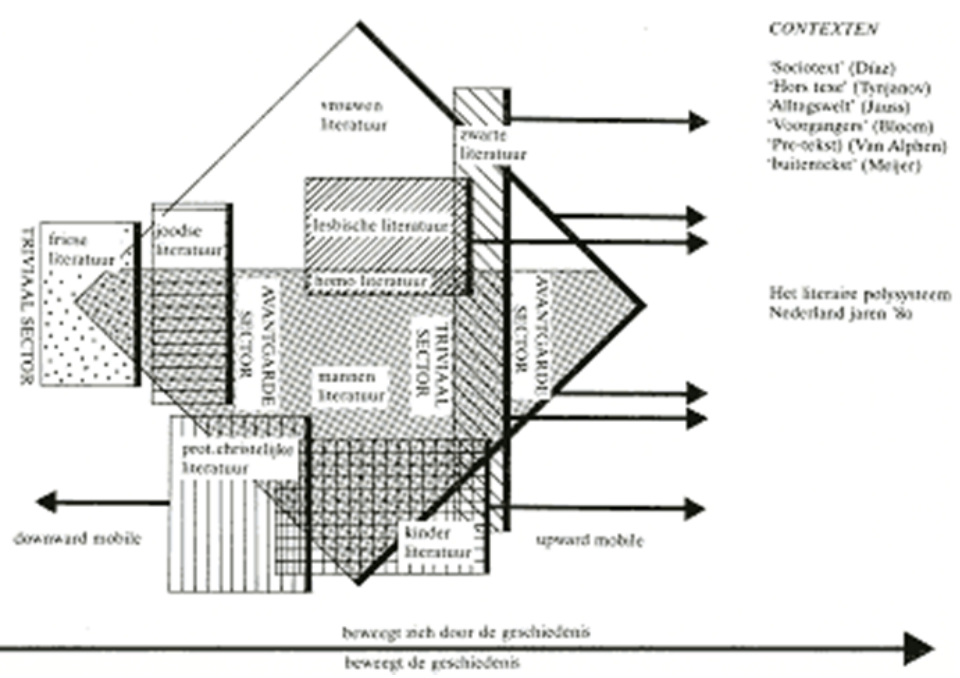

texatege de geschiofenis

Fig. 4 Meijers 'Literaire Polysysteem Nederland jaren '80' (Meijer,1988, p. 338).

De analyse van de Nederlandstalige literatuur die Meijer heeft verricht, is een verhelderend voorbeeld van de toepassing van de polysysteemtheorie van EvenZohars. Ze illustreert haar betoog met een schema waarmee in één oogopslag de samenhang te zien is tussen de verschillende Nederlandse literaire stromingen, genres en stijlen, inclusief hun status ten opzichte van het Nederlandse literaire centrum en de Nederlandse literaire periferie in de jaren tachtig, en inclusief de notie van een voortgang in de tijd. Er is uit op te maken dat literaire stromingen en stijlen op te vatten zijn als zelfstandige grootheden met een eigen dynamiek. Maar onmiskenbaar staan ze ook allemaal met elkaar in verband binnen een groter geheel.

We kunnen in de geest van Meijer en Even-Zohar het theatersysteem als polysysteem beschouwen, bestaande uit een veelvoud van subsystemen, allemaal met een centrum en een periferie. Het equivalent van het min of meer geaccepteerde literaire triviale bij Meijer zouden we in het theater toe kunnen schrijven aan het domein rond grootheden als commerciële musicalproducenten en commerciële omroepen maar ook aan prosumeringsprocessen (een samentrekking van produceren en consumeren) rond theatercursushuizen, aan grootschalige talentjachten en aan self design op Facebook en YouTube. Later, in de jaren negentig, zal Meijer begrippen als intertekstualiteit en intervisualiteit uitdiepen als betekenissturend in een literair perspectief. Ook deze begrippen zijn in een performatieve context goed te hanteren om het differentiatieproces binnen en rond het huidige theater te beschrijven. In hoofdstuk 3, 'Intertekstualiteit en sekse', van In tekst gevat. Inleiding tot een kritiek van representatie (1996) zegt Meijer: 
'Wanneer vrouwen (en zwarte auteurs, homoseksuelen, lesbiennes, en andere 'anderen') de pen opnemen doen zij dat in een culturele ruimte waar de betekenissen al in een bepaalde richting zijn vastgelegd. Zij schrijven met andere woorden in een 'vreemde' schrijfcultuur, waarbinnen zij zich toch verstaanbaar moeten maken. Het gaat er dan voor deze auteurs vaak om zich 'los te schrijven' uit, en zich te verweren tegen, tradities die hen tegelijk ook gevormd hebben. Dat leidt tot een hoogst polemisch intertekstueel verkeer tussen de nieuwe 'andere' tekst en al bestaande teksten' (Meijer, 1996, p.38.).

In hetzelfde hoofdstuk legt ze uit dat deze bevindingen niet alleen opgaan voor de literatuur, maar veel breder inzetbaar zijn:

'Intertekstualiteit speelt zich niet alleen af in literaire teksten, noch alleen in taalteksten. Ook in andere verschijnselen - mode, videoclips, reclamebeeldenwordt druk gebruik gemaakt van inter'tekst'ualiteit. Ook daar wordt geciteerd uit traceerbare voorafgaande teksten, ook daar bestaan modellerende genres en heersende conventies van representatie' (Meijer, 1996, p. 59).

Verwijzend naar de introductie van het begrip intertekstualiteit door Julia Kristeva spreekt Meijer van transpositie van tekstelementen uit andere tekensystemen naar een nieuw tekensysteem. Ze beperkt zich overigens met haar analyses tot één systeem, het literaire systeem, terwijl de met intertekstualiteit in verband te brengen begrippen als intermedialiteit, interculturaliteit en interdisciplinariteit, waarnaar in deze studie veelvuldig wordt verwezen, die beperking overstijgen en meerdere systemen tegelijkertijd raken. ${ }^{39}$ Zo verwijzen begrippen als beeldcitaat, montage, inzoomen, scenograaf, ruis, fade away en point of view naar in beginsel verschillende betekenissystemen, die langzaam maar zeker steeds meer begrippen met elkaar zijn gaan delen. Expliciete vormen daarvan zijn te vinden in live performances en hybride voorstellingen, waarbij sprake is van een voor de enscenering als halffabricaat te beschouwen bronmateriaal uit een ander medium. Het levert begin 21 e eeuw theatervoorstellingen op die niet zijn gebaseerd op toneelteksten maar bijvoorbeeld op speelfilms of romans. Voorbeelden zijn Opening Night (2007) en Husbands (2012), beide geregisseerd door Ivo van Hove bij Toneelgroep Amsterdam, naar de gelijknamige films van John Cassavetes; de Proust cyclus (2002-2005) door het Ro Theater in een regie van Guy Cassiers, naar de romancyclus $A$ la recherche du Temps

\footnotetext{
${ }^{39}$ Voor de specifieke relatie tussen intermedialiteit en intertextualiteit zie Rajewski (2005). Rajewski spreekt hier over drie soorten uitleg van intermedialiteit: mediacombinaties, mediatransposities en intermediale referenties. De laatste variant ziet zij als de intermediale tegenhanger van intertextualiteit.
} 
perdu van Marcel Proust en later, ook door Cassiers, De man zonder eigenschappen (2010-2012) naar de monumentale roman van Robert Musil.

Nog een stap verder is te zetten door het begrip intertekstualiteit te vergelijken met het begrip intermedialiteit, gedefinieerd door Kattenbelt, Chapple, Bay-Cheng en anderen (Chapple \& Kattenbelt, 2006; Bay-Cheng, Kattenbelt, Lavender, \& Nelson, 2010). Het is niet moeilijk in de filmtoepassingen binnen het theater, in theatrale aspecten binnen filmproductie en in andere vergelijkbare hybride toepassingen van oude media binnen nieuwe en andersom, de 'anderen' in de redenering van Meijer te zien, zoals het volgende citaat van Chapple \& Kattenbelt uit 2006 toont:

"In looking to define intermediality, our starting point is that a significant feature of contemporary theatre is the incorporation of digital technology into theatre practice, and the presence of other media within theatre productions. In turn, film, television, and digital media reference theatre in a variety of ways. Therefore, a first assumption is that intermediality is associated with the blurring of generic boundaries, crossover and hybrid performances, intertextuality, intermediality, hypermediality and a self-conscious reflexivity that displays the devices of performance in performance. From here we can see that there is a need to access how the incorporation of digital technologies and the preference of other media within the theatrical and performance space is creating new modes of representation; new dramaturgical strategies; new ways of structuring and staging words, images, and sounds; new ways of positioning bodies in time and space; new ways of creating temporal and spatial interrelations. These new modes of representation are leading to new perceptions about theatre and performance and to generating new cultural, social and psychological meanings in performance" (Chapple \& Kattenbelt, 2006, p. 11).

Hetzelfde geldt voor het begrip interculturaliteit dat in verscheidene richtinggevende publicaties gebruikt wordt (Schechner, 2002b; Jans, 2006a; Scheffer, 2007). De essentie van dit begrip ligt in het accepteren van het afwijkende, daarbij in acht nemend dat deze acceptatie gepaard gaat met confrontatie, met het tegenover elkaar staan in discoursen. ${ }^{40}$ De gezamenlijke ambitie van velen die dit soort inter-termen hanteren is uiteindelijk minder conflictueus om te gaan met elkaars benaderingen van de wereld. Dit staat in tegenstelling tot de essentie van een begrip als multiculturaliteit, dat in beginsel uitgaat van egaliteitsdenken waarbij dynamische

\footnotetext{
${ }^{40}$ intercultureel (bn), de relatie van versch. culturen betreffend, tussen de culturen: intercultureel onderwijs (Van Dale, 1992).
} 
interactie niet of te weinig ingecalculeerd wordt. ${ }^{41}$ Even-Zohars theorie is bruikbaar voor een analyse van veranderingen in tal van cultuurdomeinen. Voor het begrijpen van een spectraal samenhangende wereld van diverse artistiek performatieve uitingen maak ik daarnaast gebruik van het begrippenapparaat van Gilles Deleuze en Félix Guattari. Met behulp van hun rizoomtheorie lijkt het mogelijk om verbindingen van niet gelijksoortige grootheden in en tussen performatieve domeinen te analyseren.

\section{Deleuzes Rizoom}

Rizoom is een term van de Franse filosoof Gilles Deleuze (1925-1995). Samen met collega-filosoof en psychoanalyticus Félix Guattari (1930-1992) schreef hij in de jaren zeventig een pamflet: Rizoom (Deleuze \& Guattari, 2004). Deze korte tekst werd als eerste hoofdstuk opgenomen in hun latere boek Mille Plateaux (Deleuze \& Guattari, $1980)^{42}$. Rizoom is een metafoor. Het is de botanische term voor een wortelstructuur waarbij de wortels van een plant zich naar alle kanten verspreiden en waarbij die plant op kortere of langere afstand weer nieuwe planten begint, met dezelfde geschakelde wortel, zie figuur 5 . Planten als de fluweelboom, sommige vaak als onkruid beschouwde grassoorten en bijvoorbeeld de brandnetel hebben dergelijke wortelstokken. Ook sommige paddenstoelsoorten planten zich op deze manier voort. Dit beeld is een manier om verbanden en structuren in de ons omringende werkelijkheid te begrijpen. Het is ook bruikbaar om de veranderende artistieke praktijk van het uitwaaierende performatieve mee te beschrijven. ${ }^{43}$

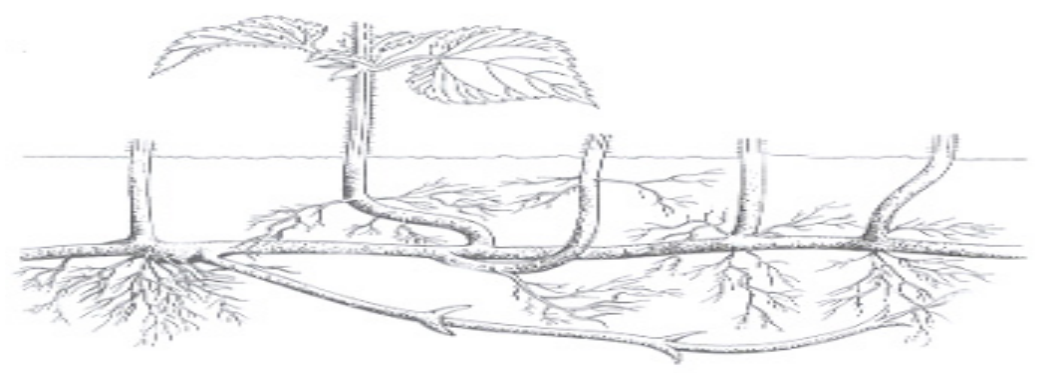

Fig. 5 Wortelstok of rizoom (Rizoom, n.d.)

\footnotetext{
${ }^{41}$ multicultureel (bij attr. gebruik is multi beklemtoond) (bn), uit (elementen van) verschillende culturen samengesteld: de multiculturele samenleving (Van Dale, 1992).

${ }^{42}$ In 2007 werd het boek opnieuw in het Engels uitgegeven. Ik baseer me in deze studie op deze vertaling.

${ }^{43}$ Ik volg daarmee Lehmann (1999, p. 154) en Kattenbelt (2006, p.19).
} 
Deleuze en Guattari hebben niet alleen de rizomatische structuur van denk- en cultuurvormen beschreven, ze hebben ook getracht de vorm van Mille Plateaux rizomatisch te laten zijn. Het boek is opgedeeld in vijftien hoofdstukken, inclusief een conclusie. De lezer kan vooraan beginnen en het boek uitlezen tot het eind. Maar elk hoofdstuk is ook los van de andere te lezen, in elke willekeurige volgorde. Zo heeft het boek veel ingangen en open eindes, net als het wereldbeeld dat de schrijvers hebben willen etaleren. Als denkwijze contrasteert het denken in rizomatische structuren sterk met het meer gangbare denken in boomstructuren. Een boom staat voor één vaste oorsprong die zich steeds fijner vertakt, één hiërarchische ordening waarop alles is terug te herleiden. Een rizoomstructuur is gebaseerd op verbinding en heterogeniteit. Rizoomdenken gaat uit van het principe van veelheid. Volgens Deleuze en Guattari verbindt een rizoom semiotische schakels, machtsorganisaties en gebeurtenissen, die naar kunst, wetenschap en sociale strijd kunnen verwijzen (Deleuze \& Guattari, 2007, p. 7). Elke rizoomstructuur bevat lijnen waarlangs betekenis vorm krijgt. Elke keer als zo'n lijn zich splitst, is dat weliswaar een breuk in het rizoom maar de nieuw ontstane lijnen blijven onderdeel van het rizoom. Deze interne breuklijnen worden vluchtlijnen genoemd, waarbij vlucht opgevat moet worden als een soort natuurlijke route die te vergelijken is met de weg die water als vanzelf zoekt als het van een heuvel af loopt. De term vluchtlijn en het termentrio territorialiseren, de-territorialiseren en reterritorialiseren vormen samen het principe van de niet-betekenisdragende breuk. Dit is een breuk die geen afscheiding of definitieve verwijdering van iets voorgaands inhoudt, maar die als richtingverandering of verdeling in meerdere richtingen integraal onderdeel blijft van het rizoom. De territoriumtermen geven aan dat er nieuwe domeinen tot het rizoom kunnen gaan behoren (territorialisering), dat er domeinen al dan niet tijdelijk - verlaten kunnen worden (de-territorialisering) en dat er domeinen na verloop van tijd opnieuw aansluiting kunnen vinden bij het rizoom (reterritorialisering).

Deleuze en Guattari maken onderscheid tussen cartografie en kopieertechniek. Zij zweren het kopiëren als repeterende representatie van hetzelfde af. Het is voor hen verbonden met hiërarchisch denken, met boomstructuren. Volgens hen is dat een logica van een kritiekloos 'overtrekken' (tracing). Cartografie daarentegen wordt als het in kaart brengen van stroompjes en wegen die het creërend denken kan inslaan in niet vooraf veronderstelde richtingen, veel interessanter gevonden. Een landkaart is van vele kanten te bekijken, zoals een landschap vanuit vele kanten te betreden is en ook weer te verlaten. Het toestaan van het veranderen van route staat centraal in het rizomatisch denken. Deleuze en Guattari definiëren de mogelijkheden van een kaart als volgt: 
"What distinguishes the map from the tracing is that it is entirely oriented toward an experimentation in contact with the real. The map does not reproduce an unconscious closed in upon itself; it constructs the unconscious. ... The map is open and connectable in all of its dimensions; it is detachable, reversible, susceptible to constant modification. It can be torn, reversed, adapted to any kind of mounting, reworked by an individual, group, or social formation. It can be drawn on a wall, conceived of as a work of art, constructed as a political action or as a meditation" (Deleuze \& Guattari, 2007, p.12).

Een rizoom is geen generatief model, het kent geen hoofdader of centrumkracht. Er bestaat volgens Deleuze en Guattari geen werkelijke oppositie tussen centra en segmenten of periferieën (Deleuze \& Guattari, 2007, p. 208).

Als we naar het historische proces van de totstandkoming van het Nederlandse theatersysteem kijken, dan kan het van 1950 tot het begin van de jaren 1970 boomgestructureerd genoemd worden. Er bestond een beperkt aantal Nederlandse toneelgezelschappen, waaronder een paar nieuwe ten opzichte van de situatie van voor de Tweede Wereldoorlog. Men had te maken met een beperkt aantal regisseurs, van wie sommigen opereerden als richtinggevende artistiek leiders. Jonge acteurs en actrices voegden zich na hun opleiding naadloos naar de mores van de Nederlandse literair dramatische theatertraditie. Er bestonden wel kritische geluiden, er druppelden ander repertoire en afwijkende praktijken binnen, maar dat waren nog slechts bescheiden, incidentele bewegingen. Voor alle spelers in het systeem was de komst van de televisie in de loop van de jaren vijftig het begin van een nieuwe werkelijkheid. Wat door de een verketterd werd als non-cultuur, was voor de ander nieuw en kansrijk. Steeds vaker gingen theateracteurs en -actrices, regisseurs, dramaturgen, vormgevers en technici werken voor het nieuwe medium. Televisie werd zo geterritorialiseerd door de traditionele theaterwereld. Andersom gebeurde in de loop van de daarop volgende decennia hetzelfde, de theaterwereld werd geterritorialiseerd door de televisiewereld. Daar waar sprake is van territorialisering van de ene wereld door een andere, is in min of meer vergelijkbare gradaties sprake van een deterritorialisering de andere kant op. Met andere woorden, in dit geval werd door het belangrijker worden van het medium televisie, de betekenis van de officiële canonieke theaterwereld omgekeerd evenredig minder van belang. Dit proces is ook te duiden met een andere Deleuziaanse term: de vluchtlijn. ${ }^{44}$

\footnotetext{
${ }^{44}$ Zie ook Williams (1977) en zijn noties dominant, residual en emergent. Het westers canoniek repertoire kan anno 2014 residual genoemd worden; het vormexperimenteel en deconstructief gestuurde karakter van het Nederlands gesubsidieerd theater van de laatste veertig jaar kunnen we dominant noemen; en het door interculturele, intermediale en internationale ontwikkelingen geraakt theater kunnen we emerging noemen. Hier zijn parallellen te trekken met Deleuzes vluchtlijnenconcept.
} 
In de decennia na 1950 raakte vriend en vijand het erover eens dat het belang van de theaterwereld alleen maar kon worden gediend door media-aandacht. Die kon op diverse manieren gegenereerd worden, bijvoorbeeld doordat theateracteurs optraden in populaire televisieprogramma's of door directe televisiereclame voor theatervoorstellingen. Dus door vluchtlijnen via andere media in de richting van mogelijk nieuw publiek konden en kunnen nieuwe vitale kanalen en netwerken aangeboord worden. ${ }^{45}$ Daarbij is de kracht van de vluchtlijn gerelateerd aan tijd, plaats en conventie. Televisie was na 1950 dominant aanwezig in het culturele leven, zoals de film dat was vanaf het begin van de twintigste eeuw, en na 1995 het explosief opkomende nieuwe medium internet. Bij Deleuze en Guattari behoren veranderingen van routes intrinsiek tot een bepaald domein of een bepaald proces. Via de vluchtlijnen vinden assemblages plaats, tijdelijke koppelingen met iets anders, met een 'buiten'.

Deze nomadische manier van beschouwen kan een wereldbeeld genoemd worden. Er kleven echter ook nadelen aan Deleuzes kosmische vermoedens. Met het schetsen van deze rizomatische manier van kijken is slechts een onthiërarchiserende abstractie mogelijk geworden van voorheen in tijd en plaats vastgelegde conventies. Alles is met alles te verbinden en het lijkt moeilijk om specifiek hedendaagse culturele dynamiek te duiden op basis van deze algemene filosofische reflecties. Voor een meer toepasbare empirische vertaling van het Deleuziaanse wereldbeeld tekent Bruno Latour een paar decennia later met zijn Actor-Network Theory (ANT) (Gielen, 2004, p. 129).

\section{Latours Actor-Network Theory}

De Franse filosoof en antropoloog Bruno Latour (1947) behoort samen met onder anderen Michel Callon, Annemarie Mol en John Law tot de grondleggers van de ActorNetwork Theory. ${ }^{46} \mathrm{Hij}$ is een vooraanstaand hedendaagse theoreticus binnen de wetenschapssociologie en houdt zich bezig met de sociologie van wetenschappelijke methodes, techniek en technologie. Om zicht te krijgen op de bruikbaarheid van ANT voor mijn onderzoek heb ik vooral gebruikgemaakt van Latours Reassembling the

\footnotetext{
${ }^{45}$ Een mooi voorbeeld: op donderdag 25 juni 2009 ging Jean Racine's Phèdre van het National Theatre in London in première, met Helen Mirren in de hoofdrol. De première kon wereldwijd gevolgd worden door betalend publiek in bioscoopzalen. Het aldus verbreden van publiek gebeurde al eerder op deze manier in de muziekwereld (New York Metropolitan Opera en Elton John). Op deze manier, als Deleuziaanse vluchtlijnen met weer nieuwe mogelijkheden, kunnen we ook het intermediale werk beschouwen van regisseurs als Guy Cassiers, Ivo van Hove en de artistiek onderzoekers van CREW, die verschillende mediatoepassingen naar believen inzetten in hun voorstellingen.

${ }^{46}$ John Law zegt hierover: "I am grateful to Annemarie Mol, Ingunn Moser, Vicky Singleton and Helen Verran for their long term intellectual friendship. All work is collective" (Law, 2007).
} 
Social. An introduction to Actor-Network-theory (2005) en van de bundel Actor Network Theory and after (Law \& Hassard, 1999). In deze laatste bundel kijken de betrokkenen kritisch terug naar de eerste twintig jaar ANT.

Latour baseerde zich bij de ontwikkeling van de ANT op de semiotische benadering van teksten die door de structuralistische literatuurwetenschapper Algirdas Greimas werd ontwikkeld in diens actantieel model. In dit analysemodel worden handelingen en relaties van mensen en gebeurtenissen niet geanalyseerd als uitsluitend menselijke of als louter individuele acties, maar als abstracte krachten die zich manifesteren tussen actanten. In Latours theorie heten de krachten actoren. In het actantiële model bekleden actanten allemaal een bepaalde functie: die van zender, ontvanger, helper, object, subject of opponent. Bij Latour liggen de functies van actoren minder vast. Ze staan in een niet-hiërarchisch geordende verhouding tot elkaar. Latour gebruikt de abstracte terminologie uit de semiotische linguïstiek om duidelijk te maken dat er ook op andersoortige terreinen dan alleen op het gebied van de taal betekenisdragende en interacterende netwerken bestaan. Die netwerken zijn krachtenvelden waar betekenissen, ambities, tegenstand en bijval op elkaar inwerken, vormgegeven door zowel menselijke actoren als door objecten, theorieën, technologieën en politieke stromingen. Alles wat kracht uitoefent of weerstand biedt, is te beschouwen als actor en deze actoren vormen samen actor networks. Toegepast op de theaterwereld: niet alleen acteurs, actrices, dramaturgen, decorontwerpers, scenografen, lichtontwerpers en impresario's zijn actoren, maar evengoed gebouwen, software, publiek, camera's, opleidingen, projectiemethoden, politieke partijen, gezelschappen, vervoerssystemen, beleidsstukken en computers. Tijdens een proces van netwerkbouw, van het leggen van nieuwe relationele verbanden, wordt de bestaande orde geherdefinieerd. ${ }^{47}$

Latour heeft met deze benadering duidelijk gemaakt dat sociologische duidingen van maatschappelijke en wetenschappelijke gebeurtenissen niet stringent vast hoeven te liggen binnen specifieke historisch gegroeide begrippenkaders. Betekenissen komen voor Latour hernieuwd tot stand door middel van associatieve betekenisgeving waarbij heterogeen materiaal zich door assemblages vormt tot nieuwe gehelen van hybriden. In de loop van de afgelopen decennia heeft de internationale groep van wetenschappers die ANT ontwikkelde, gewerkt aan de verfijning van deze inzichten, inclusief diverse zelfkritische publicaties. In 2007 omschreef John Law ANT als volgt:

"Actor-network theory is a disparate family of material-semiotic tools, sensibilities and methods of analysis that treat everything in the social and the natural worlds as a continuously generated effect of the webs of relations within

\footnotetext{
${ }^{47}$ Een goed voorbeeld van een gevalstudie naar netwerkbouw in de ANT-traditie is beschreven door Michel Callon (Callon, 1986).
} 
which they are located. It assumes that nothing has reality or form outside the enactment of those relations. Its studies explore and characterise the webs and the practices that carry them. Like other material-semiotic approaches, the actornetwork approach thus describes the enactment of materially and discursively heterogeneous relations that produce and reshuffle all kinds of actors including objects, subjects, human beings, machines, animals, 'nature', ideas, organisations, inequalities, scale and sizes, and geographical arrangements" (Law, 2007, p. 2).

Een van Latours centrale begrippen is translation. Het staat voor een proces waarbij de betekenis van een element verschuift als de positie van dat element in een associatief samenhangend geheel verandert. Met andere woorden, betekenisclusters ademen als het ware in een groter contextueel geheel. Objecten, personen en handelingen zijn niet voor de eeuwigheid eenduidig van betekenis, maar veranderen door wisselende allianties regelmatig van betekenis. ANT is wel poststructuralistisch genoemd door de manier waarop getracht wordt de dynamische samenhang der dingen te verklaren, in tegenstelling tot de benadering van de structuralisten, die op zoek leken naar een protostructuur als een statisch verklarend raster. Voor Latour is de modernistische dichotomie van cultuur tegenover natuur een poging tot purification die niet werkt. In plaats daarvan gaat hij uit van de veronderstelling dat we voortdurend verwikkeld zijn in translatieprocessen. Met ANT wordt het mogelijk te beschrijven hoe het menselijke bestaan voortdurend aan verandering onderhevig is en hoe dat ertoe leidt dat ons wereldbeeld steeds moet worden bijgesteld.

Latour beschrijft in Reassembling the Social. An Introduction to Actor-NetworkTheory (2005) onder andere hoe het begrip social in de loop van de negentiende en de twintigste eeuw langzaam van lading veranderde. Hij start met de etymologische herkomst van het begrip. Het is afgeleid van het Latijnse sequi en de eerste betekenis is volgen; het Latijnse socius betekent compagnon, partner. In de achttiende eeuw krijgt het een volgende betekenis door Rousseaus formulering van het sociaal contract. In de negentiende eeuw ontstaan samentrekkingen als sociale problemen en de sociale kwestie. Eind twintigste eeuw kennen we sociaal werkers. Na de brede definitie die gebaseerd was op verbanden tussen mensen en gemeenschappen, kennen we nu volgens Latour nog slechts definities die beperkt zijn doordat vele associaties met sociaal door de politiek, biologie, economie, rechtswetenschappen, psychologie en technologie onttrokken zijn aan het oorspronkelijke koepelbegrip. Hij eindigt met de constatering dat de draagwijdte van het begrip social in een paar honderd jaar is 'gekrompen' tot een veel te beperkte uitleg van menselijke relaties en moderne samenlevingen: "As one can see from the drifting of the word, the meaning of social shrinks as time passes" (Latour, 2005, p. 6). 
In translatieprocessen onderscheidt Latour mediators en intermediairs. Hij definieert een mediator als een black box, een actor die ervoor zorgt dat de elementen die hij draagt gaandeweg veranderen: wat erin gaat komt er anders en onvoorspelbaar uit, of zoals Latour het formuleert: "Mediators transform, translate, distort, and modify the meaning or the elements they are supposed to carry" (Latour, 2005, p.39). Intermediairs zijn actoren die slechts doorgeven zonder een verandering te bewerkstelligen: door te zien wat erin gaat, kun je veronderstellen wat eruit komt. Latour spreekt over dit verschil tussen mediatoren en intermediairs als over het verschil tussen translation en transportation Het traditionele transporteren van causaliteit wordt beschouwd als eenrichtingverkeer langs een beperkte en statische oorzaak-gevolglijn. Door translatie vindt een structurele verandering plaats van de identiteit van de vertaalde elementen, is er sprake van een dynamische verandering van elementen door mediators. Dat levert mogelijk een geheel ander wereldbeeld op dan een door vaststaande canonieke centrumkrachten gedomineerde cultuur. Deze assemblerende vertaalprocessen stellen Latour in staat, zoals hij zelf zegt, om meer precies het doel van een geherformuleerde sociale wetenschap te bepalen: "There is no society, no social realm, and no social ties, but there exist translations between mediators that may generate traceable associations" (Latour, 2005, pp. 106-109).

Latour beschrijft tegen deze achtergrond een aantal onzekerheden waarmee sociale wetenschappers en degenen die gebruik maken van hun onderzoeksresultaten zullen moeten leren leven. Hij ziet het als het in stelling brengen van een aantal prikkelende controverses om processen mee op gang te brengen. Bij het uitvoeren van de gevalstudies van exemplarische instituties binnen het theatersysteem lijken me Latours begrippen controverses en uncertainties van toepassing. Bij het analyseren van veranderingsprocessen in het Nederlandse theaterlandschap gaat het net als in Latours onderzoekspraktijk over het wel of niet vastliggen van de aard van groepen en van hun identiteiten, over het maatschappelijk gewicht van belanghebbenden, over de flexibiliteit van aard en werking van maatschappelijke instituties, over het gewicht van handelende personen en objecten. Het gaat over het verschil tussen vaststaande feiten en regelmatig wisselende belangen, ofwel over het verschil tussen matters of fact en matters of concern.

"A matter of concern is what happens to a matter of fact when you add to it its whole scenography, much like you would do by shifting your attention from the stage to the whole machinery of a theatre. ... Instead of simply being there, matters of fact begin to look different, to render a different sound, they start to move in all directions, they overflow their boundaries, they include a complete set of new actors, they reveal the fragile envelopes in which they are housed" (Latour, 2005, p. 39). 
Zoals Latour zijn ANT inzet om maatschappelijke verhoudingen en de uitleg daarvan kritisch te bevragen, zo wil ik dat in deze studie doen met het theaterlandschap, door vanzelfsprekend geachte patronen en verhoudingen tussen actoren in en rond de podiumkunstenwereld op hun actuele werking te bevragen. Gevestigde traditionele theaterinstituties lijken zich soms los te zingen van actuele culturele bewegingen die waarneembare effecten hebben op het performatieve. Er lijkt meer aan de hand dan hetgeen door het huidige theatersysteem gedekt wordt. Of zoals Latour het uitdrukt: "When you wish to discover the new unexpected actors that have more recently popped up and which are not yet bona fide members of 'society' you have to travel somewhere else and with very different kinds of gear" (Latour, 2005, p. 22).

\subsection{Praktijk als onderzoekscontext: Practice as Research}

De kunstpraktijk als onderzoeksterrein beschouwen heeft een opkomend onderzoeksveld opgeleverd, gekenmerkt door de emancipatie van kennisproductie in en vanuit de praktijk (Nelson, 2013). In Groot Brittannië bestaat deze onderzoekspraktijk in geformaliseerde zin al langer, daar heet zij Practice as Research (PaR). De Engelse theater-, performance- en mediawetenschapper Robin Nelson publiceerde in 2013 een overzicht van de geschiedenis en de stand van zaken voor wat betreft deze relatief nieuwe onderzoeksmethodologie: Practice as Research in the Arts. Principles, Protocols, Pedagogies, Resistances (Nelson, 2013). In PaR worden manieren van kennen en weten tegen elkaar afgezet in een cruciale wisselwerking tussen know how (tacit knowledge, embodied knowledge, performative knowing), know what (know what works, know what methods) en know that (conceptual frameworks, cognitive propositional knowledge, outsider distant knowledge) (Nelson, 2013, p. 37). Het gaat bij PaR om onderzoeksprojecten waarbij de procesgang en de resultaten van het uitvoerende werk als methodologisch belangrijk deel van het onderzoek worden beschouwd. In de academische wereld wordt nieuwe kennis geproduceerd op basis van gestandaardiseerde meetmethodes en gestructureerde betogen. Deze academische methodes verhouden zich moeizaam tot de manier waarop in de kunsten inzichten worden verworven. Het artistieke uitvoerende werk van kunstenaars als onderzoekspraxis beschouwen, is zowel voor de academische wereld als voor de kunstpraktijk zelf nog vaak een uitdaging (Borgdorff, 2012). Het gaat daarbij om een goede verhouding tussen theorie en praktijk. Of zoals de Vlaamse kunstsocioloog Pascal Gielen schrijft:

'Het gaat dus niet alleen om een juiste balans tussen beide, maar om de manier waarop ze op elkaar inwerken. Idealiter tast men de materiële werkelijkheid af met behulp van theoretische kennis en worden theoretische inzichten eventueel 
bijgestuurd door het aftasten. In Marxistisch jargon zouden we zo'n correcte interactie ook praxis kunnen noemen. Zonder daarvoor per se de ideologische achtergrond te hoeven overnemen, betekent praxis een soort belichaamde kennis. Maar het wijst ook op een tweezijdige verhouding tussen theorie en handelen die we als handelen door theoretische kennis én handelende theorie heen zouden kunnen noemen. Het gaat om een verhouding van permanente 'interpenetratie' tussen theorie en praktijk' (Gielen, 2013, p. 74).

In de kunsten zijn de dans en het theater, waarschijnlijk door het vluchtige karakter ervan, pas veel later in aanraking gekomen met onderzoek dan de literatuur, de muziek, de film of de beeldende kunst. Het aan podiumkunsten ontleende performanceconcept echter heeft in de loop van de tweede helft van de twintigste eeuw geaccepteerde nieuwe manieren van kennen en weten met zich meegebracht zowel in de wereld van de kunsten als in de academische wereld. Nelson verwijst onder andere naar Jon McKenzies uitspraak in Perform or Else: From Discipline to Performance (McKenzie, 2001) :

"...'performance will be to the twentieth and twenty-first century what discipline was to the eighteenth and nineteenth, that is an onto-historical formation of power and knowledge.' Indeed, performance and the performative have become influential concepts in a number of academic disciplines" (Nelson, 2013, p. 4).

Deze expliciete verwijzingen naar performance en naar het performatieve hebben alles te maken met de manier waarop de onderzoekspraktijk van PaR gekenschetst kan worden. Volgens Nelson gaat het om onderzoeksprojecten waarbij de uitvoerende praktijk de sleutelmethode is van het onderzoek op basis van het doing-thinkingprincipe; reflectief handelen levert stap voor stap nieuwe inzichten op. Voor de kunsten betekent dit dat de resultaten van een kunstpraktijk, in hun aard performatief, kunnen worden onderkend als mogelijk kennisopleverend en als geldig onderzoeksresultaat. Daarbij tekent hij aan dat het in Engeland al lang niet meer exclusief gaat om arts practitioners, om professioneel uitvoerende kunstenaars, maar dat PaR ook kan worden toegepast door anderen: "Educational, ethnographic and many other disciplinary practices might equally follow the PaR model to be proposed" (Nelson, 2013, p. 9).

Het is volgens Nelson van belang om bij elk soort van onderzoek enige bescheidenheid te betrachten. Nieuwe "paradigm shifting knowledge" is slechts voor zeer weinigen weggelegd: "Einsteins are few" (Nelson, 2013, p. 27). Hij onderscheidt naast dit genereren van nieuwe kennis echter een categorie die voor veel onderzoekers meer bereikbaar is en niet minder nastrevenswaardig; hij noemt dit het 
genereren van "substantial new insights" (Nelson, 2013, p. 27). Het genereren van deze substantiële nieuwe inzichten impliceert dat onderzoekers dienen te weten wat gevestigde kennis en gevestigde inzichten zijn. Wat de kunsten betreft betekent dit dat ze dienen te weten wat er in het kunstvakgebied en in de context daarvan aan de hand is, wat welke kunstenaars historisch gezien hebben bewerkstelligd en waar collegaonderzoekers op dit moment mee bezig zijn. In delen van de Angelsaksische wereld is deze kennisvergaring, die van het opdoen van nieuwe inzichten naast het genereren van nieuwe kennis via de traditionele academische methodes, inmiddels formeel in onderzoeksprotocollen beschreven en geaccepteerd. Daarbij tekent Nelson aan dat intellectueel hoogstaand werk van welke soort dan ook hoogstwaarschijnlijk in de meeste gevallen zal resoneren met ideeën en vraagstukken die elders, in andere cultuurdomeinen en onderzoeksgebieden, een constituerende rol spelen (Nelson, 2013, p. 32). Het is voorstelbaar dat op basis van Nelsons PaR-model (Nelson, 2013, p. 37) dit resoneren betekent dat er een constante uitwisseling plaatsvindt tussen kennisgebieden, tussen know how (actuele insider kennis), know what (overgeleverde specifieke vakkennis) en know that (publieksonderzoeken, conceptstudies).

Wat betekent dit alles voor mijn onderzoek dat vanuit de praktijk vorm heeft gekregen? In het inleidende eerste hoofdstuk van dit boek heb ik beschreven hoe ik hogere vakopleidingen en kennisinstituten reken tot de constitutieve pijlers van het gevestigde theatersysteem. Eenieder die professioneel werkzaam is binnen een van die pijlers, kunnen we potentieel rekenen tot het systeem van de kunstenpraktijk. In ieder geval beschouw ik mezelf als docent-onderzoeker op een kunstvakonderwijsinstituut als een praktijkbetrokkene, of om in de woorden van Donald Schön te spreken, als een reflective practitioner (Schön, 1983).

De Toneelacademie Maastricht verhoudt zich op een welhaast vanzelfsprekende manier tot de veranderende theaterpraktijk. Daarbij is gedurende de periode van mijn docentenpraktijk, vanaf begin jaren negentig, het performancebegrip steeds meer op de voorgrond getreden als richtinggevend voor het doorontwikkelen van het curriculum van de theateropleiding en de afstudeervarianten (acteur, regisseur, performer, theaterdocent, theatervormgever). De manier waarop in mijn onderzoeksomgeving met die veranderende artistieke theater- en performancepraktijk is omgegaan de laatste vijftien jaar, is te omschrijven als een onderzoekspraktijk van doing-thinking (Nelson, 2013), van het op de veranderende artistieke praktijk gebaseerd ontwikkelen van substantiële nieuwe inzichten en kennis. Het heeft de positie als docent-onderzoeker van mij en een aantal van mijn collega's over een lange periode gekleurd. We zouden kunnen zeggen dat langzaam maar zeker gedurende deze periode het eenduidig vakmatig trainen van jonge theaterprofessionals aangevuld is met een praktijk van het gaandeweg ontwikkelen van kennis over de samenhang tussen veranderende theater-, film-, televisie-, kunst- en performancepraktijken. 
Centrale concepten als performance, postdramatisch theater, practice as research, liveness, en in toenemende mate intermedialiteit hebben daarbij een richtinggevende rol gespeeld.

In deze positie als docent en onderzoeker heeft mijn werk als docent methodologische consequenties voor mijn onderzoek. Het uitvoerende werk wordt daarbij als methodologisch belangrijk deel van het onderzoek beschouwd. In termen van $\mathrm{PaR}$ zouden we de manier waarop praktijkgestuurde doing-thinking-processen op de Toneelacademie hebben geleid tot substantiële nieuwe inzichten kunnen beschouwen als een deel van de onderzoeksresultaten die zijn opgenomen in de tekst van dit boek. Deze nieuwe inzichten hebben op diverse manieren gevolgen gehad voor opeenvolgende cohorten studenten, voor mijn collega's en voor mijzelf. De afgelopen vijftien jaar doing-thinking heeft nieuwe studierichtingen opgeleverd (de bachelor performanceopleiding, i-Arts, masteropleidingen); het heeft sinds 2002 nieuwe, deels rijksgefinancierde onderzoeksprogramma's voor de Toneelacademie opgeleverd (het lectoraat Nieuwe Theatraliteit, het lectoraat Autonomie \& Openbaarheid in de kunsten, het lectoraat Technology Driven Art); het heeft geleid tot groeiende positieve respons vanuit de praktijk van festivals en podiumkunstenfondsen op de manier waarop studenten van Maastricht in toenemende mate blijk geven van het gevolgd hebben van een innovatief en zelfreflectief opleidingstraject.

Het is niet mijn opzet geweest nieuwe kennis te genereren door in strikt positivistische zin wetenschappelijk iets te bewijzen door grote hoeveelheden data te verzamelen en te analyseren. Wat mijn ambities heeft gevoed, is de drang om door reflectief denken en handelen als docent op een kunstvakopleiding de actualiteit van de theater-, performance- en mediapraktijk zo goed mogelijk te dienen door het kwalitatief hoogwaardig opleiden van jonge mensen tot podiumkunstprofessionals. Als dramaturgiedocent van aankomende professionals in de context van een sterk praktijkgericht curriculum ${ }^{48}$ ben ik op een specifieke manier, anders dan de meeste wetenschappers, geschakeld aan de actuele artistieke theaterpraktijk en de culturele context. Een kunstvakopleiding bereidt de toekomst voor door kennis, vaardigheden en uitgekristalliseerde nieuwe inzichten door te geven. Na het afstuderen volgt in de beroepsuitoefening of in eventuele masterprogramma's het doorontwikkelen van die kennis, vaardigheden en inzichten. Alles wat zich voorts in die artistieke praktijk voordoet, wordt op de opleiding weer reflectief beschouwd en krijgt door gastdocentschappen een plaats in het curriculum van de opleiding, een repeterende beweging.

Lehmann schreef in 1999 over een veranderende theatersector, in termen van een zich ontwikkelende nieuwe theateresthetiek. Fischer-Lichte schreef over een

\footnotetext{
${ }^{48}$ Met een groot aandeel in het onderwijs van gastdocenten uit de Nederlandse en Vlaamse wereld van de podiumkunsten, performance-kunst, film, en media.
} 
esthetiek van het performatieve in de kunsten. Auslander, Dixon en Kattenbelt schreven specifiek over de enorme en complexe rol van technologie voor het theatrale en het performatieve. Met dit onderzoek probeer ik de betekenisvolle samenhang van theater en performance met de context van bredere performatieve netwerken herkenbaar te maken. Dit beschrijven van de beweging van de monolithische benadering van theater en performance als kunstcategorieën naar het articuleren van een bredere performatief spectrale samenhang, kan gezien worden als mijn bijdrage aan het discours dat zich na Lehmanns publicatie van Postdramatisches Theater ontrolde.

De afgelopen jaren ben ik voor een deel van mijn reguliere taken vrijgesteld geweest om het reflectieproces te intensiveren in de vorm van mijn onderzoekstraject, geformaliseerd en uitgevoerd onder de paraplu van het Lectoraat Autonomie \& Openbaarheid in de kunsten van Zuyd Hogeschool. De bevindingen zullen via curriculumontwikkeling en beleidsaanpassingen van het onderwijsinstituut en via het uitbouwen van professionele netwerken hun weg terug vinden naar de theaterpraktijk. Deze dialoog ontrolt zich als een dynamisch proces en raakt alle constituerende domeinen van het theatersysteem, zoals we zullen zien in de hierna volgende casestudies. 



\section{Hoofdstuk 3 Theatergezelschap in transitie}

'De identiteit van het hedendaagse Vlaamse theater bestaat dus uit een eindeloze opsomming: de kunstwerken en voorstellingen zelf natuurlijk, de makers, acteurs, techniekers, critici, producers, toeschouwers, maar ook de politici die het kunstbeleid bepalen, de theaters en de plek die ze innemen in de steden, de horeca die ermee verweven is, hun productleveranciers, en je kan zo tot in het oneindige blijven verbinden... Totdat je merkt dat écht alles en iedereen er eigenlijk bij hoort. Misschien zijn niet alle elementen even belangrijk voor $u$ of voor mij, maar geen enkel is zonder belang. Raakt men aan één element, dan trilt het hele wezen. Hedendaags theater is één groot sociaal en maatschappelijk verband' (Cherkaoui, 2008, p. 4). ${ }^{49}$

\subsection{Inleiding}

In deze eerste van vier gevalstudies beschouwen we het productie-element van het theatersysteem, het domein van de theatergezelschappen. De termen toneelgezelschap en theatergezelschap worden doorgaans door elkaar gebruikt. Een toneel-/theatergezelschap is voor de meeste mensen een artistiek bedrijf dat voorstellingen produceert. Er bestaat een standaardbeeld van een gezelschap als een groep professionals, bestaande uit een of meer regisseurs, een aantal acteurs en actrices, een ploeg technici, een administratieve staf en enkele medewerkers voor public relations. Mensen die meer bekend zijn met de sector weten dat er ook dramaturgen, filosofen of schrijvers lid kunnen zijn van de artistieke staf. In deze samenstelling zal een toneelgezelschap zich in de beleving van velen bezighouden met het instuderen en spelen van stukken uit het repertoire van meestal westerse canonieke literair dramatische toneelteksten. In Nederland bestaat wat we een nationale toneelcanon zouden kunnen noemen uit teksten behorende tot het bescheiden historische Nederlandstalige toneelrepertoire, een omvangrijke Nederlands-Vlaamse naoorlogse aanwas van nieuwe stukken en vertalingen van de

\footnotetext{
${ }^{49}$ Uit de openingstoespraak ('State of the Union') van het Theaterfestival in Antwerpen, uitgesproken door Sidi Larbi Cherkaoui, samen met Laura Neyskens en Sandra Delgadillo op 22 augustus 2008.
} 
Griekse klassieken en Frans, Duits, Russisch, Scandinavisch, Amerikaans en Engels literair dramatische toneelrepertoire.

Lehmann concludeerde naar aanleiding van zijn studie naar theaterontwikkelingen aan het eind van de vorige eeuw dat toneel en toneelrepertoire inmiddels niet meer normstellend is voor de gehele theatersector, waarbij toneel staat voor het tekstgeoriënteerde dramatische met een centrale rol voor de illusoire fictie. De veronderstelling die aan deze eerste gevalstudie ten grondslag ligt, is dat theaterproductie in de hedendaagse culturele context verdergaande transformaties ondergaat. Op basis van deze veronderstelling staat de vraag centraal: hoe verhouden gevestigde theatergezelschappen zich tot actuele ontwikkelingen in hun cultureel dynamische context? Meer concreet: welke veranderingen zijn waar te nemen in repertoire, productiewijze, samenstelling en organisatie van gezelschappen? Om hier een beeld van te krijgen heb ik ervoor gekozen om een opmerkelijk gesubsidieerd grootschalig theatergezelschap, Toneelhuis Antwerpen, in het kader van dit onderzoek tot object van studie te maken. Een gesubsidieerd gezelschap om te tonen dat ook gevestigde theatergezelschappen zich kunnen voegen naar nieuwe omstandigheden. Ik koos voor Toneelhuis omdat het bij de reconstructie in 2006 radicale keuzes heeft gemaakt voor wat betreft het te spelen repertoire, de personele structuur van het theaterbedrijf, het inzetten van technologie en de relatie met de stad Antwerpen. De structurele keuzes die artistiek leider Guy Cassiers en de zijnen maakten, zijn ingezet op basis van intermediale, interculturele en internationale ambities. Dat maakt het gezelschap exemplarisch voor culturele organisaties die zich trachten te verhouden tot de netwerksamenleving.

De andere drie gevalstudies in dit onderzoek zijn Nederlands, waardoor deze Vlaamse studie een beetje een buitenbeentje lijkt; toch meen ik de keuze te kunnen rechtvaardigen. Uiteraard verschillen de politieke en culturele omstandigheden van Nederland en België van elkaar: de cultuurbudgetten zijn anders, de politiek beweegt zich in een ander landschap en zelfs het publiek voor theater verschilt in beide landen van elkaar (Hoeven, 2005). Het samenspel van de instituties gezelschap, podium, opleiding en beleid in het Nederlandse en het Vlaamse theaterlandschap is echter met elkaar te vergelijken. Het Nederlandse taalgebied wordt bovendien door belangrijke theaterleiders als één te bespelen gebied gezien. Daarnaast is theater produceren en opvoeren op het niveau van gezelschappen als Toneelhuis voor een belangrijk deel internationaal aan het worden. Cassiers was ook in Nederland artistiek leider van een grootschalig gesubsidieerd theatergezelschap, het Ro Theater in Rotterdam. Tekenend is dat er vanaf het begin van de 21 e eeuw structureel samengewerkt wordt door grote 
Europese gezelschappen als Toneelgroep Amsterdam, Ro Theater Rotterdam, Münchener Kammerspiele, NTGent en Toneelhuis Antwerpen. ${ }^{50}$

Mijn onderzoek naar Toneelhuis bouwt voort op een eerder onderzoek waaraan ik heb meegewerkt (Havens, Kattenbelt, Ruijter \& Vuyk, 2006). Sinds ongeveer 1995 volg ik het werk van Cassiers, vanaf seizoen 2006-2007 heb ik ook zijn collegatheatermakers van Toneelhuis gevolgd. Een groot deel van het empirisch materiaal bestaat uit de neerslag van open interviews met medewerkers van het gezelschap. Artistiek leider Cassiers en dramaturg Erwin Jans sprak ik meerdere malen. ${ }^{51}$ Daarnaast heb ik gesproken met een van de Toneelhuiskunstenaars van het eerste uur, Peter Missotten, met artistiek coördinator An-Marie Lambrechts en met een van de koersbepalende theatertechnici uit de beginjaren, Arjen Klerkx. Voor paragraaf 3.2 heb ik behalve van deze interviews ook gebruikgemaakt van publicaties over het werk van Cassiers en de zijnen via gezelschapsarchieven, via de internetsite van het gezelschap en via contextueel literatuuronderzoek. Ik heb de onderzoeksresultaten thematisch georganiseerd waarbij ik delen uit de interviews en data uit de documenten heb verwerkt. Vervolgens heb ik in paragraaf 3.3 de resultaten geanalyseerd met behulp van Deleuzes begrippenapparaat en heb ik ze in verband gebracht met de belangrijkste issues uit het theaterdiscours van na Lehmann. In paragraaf 3.4 sluit ik dit hoofdstuk af met conclusies.

\subsection{Toneelhuis Antwerpen}

\section{Verkenning van de grens tussen theater en technologie}

Guy Cassiers is graficus van huis uit en is in het theater terechtgekomen vanuit de beeldende kunst. In 1987 begonnen bij het Gentse jeugdtheatergezelschap Oud Huis Stekelbees, ging hij in de jaren negentig freelance werken en regisseerde hij zijn eerste theaterwerk bij het Ro Theater in Rotterdam. Daar ontwikkelde hij een eigenzinnige, dramaturgisch inventieve inzet van technologie in theatervoorstellingen. Deze inzet werd gaandeweg van een hoogstaand niveau en de betrokken technici, ontwerpers en andere artistiek verantwoordelijken groeiden tijdens het werkproces naar elkaar toe;

\footnotetext{
${ }^{50}$ In de loop van 2013-2014 zijn er plannen voor een vergaande samenwerking tussen de genoemde gezelschappen. In dit verband worden ook Thalia Theater in Hamburg genoemd en het festival Ruhrtriennale.

${ }^{51}$ Mijn onderzoek vond voor een deel plaats onder auspiciën van het Lectoraat Autonomie en Openbaarheid in de kunsten (AOK) van de Hogeschool Zuyd. Dit lectoraat werd voorafgegaan door het onderzoeksproject van het lectoraat Nieuwe Theatraliteit. In dat onderzoek zijn er sinds 2002 vanuit het lectoraat veel contacten geweest met Cassiers, destijds nog werkzaam bij het Ro Theater te Rotterdam. Verkennende gesprekken met medewerkers van Toneelhuis met het oog op het onderzoek voor dit boek vonden plaats in het voorjaar van 2007. De eerste interviews zijn afgenomen in februari 2008, het laatste eind 2008.
} 
het onderscheid tussen artistieke disciplines viel in de repetitieperiodes meer en meer weg. 52

Een doorbraak op dat gebied vond plaats toen hij tussen 2003 en 2005 de vierdelige Proustcyclus realiseerde, op basis van de zevendelige romanreeks $A$ la Recherche du Temps perdu van Marcel Proust. ${ }^{53}$ Op 5 maart 2003 bezocht ik de première van Proust 1: De Kant van Swann in de Rotterdamse Schouwburg. Wat ik me levendig herinner van die voorstelling is dit: mooi uitgelicht, sober en intrigerend staan drie hightech camera's op standaards ongeveer midden op het voor de rest lege, immense podium. Een gordijn daalt langzaam neer en sluit de gehele toneelopening af, de camera's zijn nu uit het zicht. Acteur Paul R. Kooij staat links vooraan naar de musici van het strijkkwartet Quatuor Danel te kijken, die melancholische muziek uitvoeren. Op het gordijn worden beurtelings woorden geprojecteerd: Een boek, Een slaapkamer, Zomer, Ochtend, Stilte, Een park, Haar mond, Namiddag, Stilte. De acteur draait zich langzaam om en loopt naar het midden van het gordijn voor de eerste scène. ${ }^{54}$ De grote schouwburgzaal in Rotterdam is uitverkocht, de toeschouwers zien hoe Kooij op het voortoneel gaat staan met zijn rug naar het publiek. Dan stopt hij zijn hoofd door een spleet in het gordijn. We zien hem nu op de rug, zonder hoofd. Hij houdt de twee gordijnhelften strak tegen zijn hals. Vanaf dat moment wordt langzaam zijn gezicht zichtbaar op het gordijn, zo groot geprojecteerd als de gehele toneelopening groot is en over hem heen. Klaarblijkelijk wordt zijn hoofd live gefilmd door een van de camera's achter het gordijn. De projectie van het immense hoofd heeft een diepblauwe gloed. De toneelopening is één groot blauw vlak met een ontzagwekkende grote close-up van het pratende gezicht van de acteur. Hij spreekt een monoloog uit als het personage van de verteller, Marcel Proust zelf: 'Lange tijd ben ik vroeg naar bed gegaan.'

In haar artikel over het videogebruik in de Proustcyclus van Guy Cassiers gaat Sigrid Merx in op de rol die video en hightechapparatuur speelt in deze serie theatervoorstellingen. Door een scherpe voorstellingsanalyse toont ze aan dat Cassiers door middel van video in een live performance een specifiek effect van verdubbeling creëert waarbij de aandacht niet wordt gevestigd op de overeenkomst maar op het verschil tussen de fysieke werkelijkheid en het beeld (Merx, 2006, pp. 48-60). ${ }^{55}$ Kooij

\footnotetext{
${ }^{52}$ In die periode waren belangrijke pioniers naast Guy Cassiers scenograaf Marc Warning, KBB (kantoor voor bewegend beeld), geluidsontwerper Diederik de Cock, lichttechnici Enrico Bagnoli en Arjen Klerkx, en videokunstenaar Peter Missotten (De Filmfabriek).

${ }^{53}$ Dit grote Proustproject bestond uit een reeks van vier groot gemonteerde theaterproducties: De kant van Swann (2003), De kant van Albertine(2003), De kant van Charlus(2004), en De kant van Proust(2005).

${ }^{54}$ Er werd voor de gelegenheid een nieuwe vertaling gemaakt door Céline Linssen en die tekst werd vervolgens voor theater bewerkt door Erik de Kuyper, Guy Cassiers en Erwin Jans.

${ }^{55}$ Merx is in juni 2009 in Utrecht gepromoveerd op haar proefschrift over het werk van Cassiers c.s.(Merx, 2009).
} 
en verscheidene anderen in het gezelschap verzetten zich aanvankelijk heftig tegen het concept vol camera's, projectieschermen en microfoons. In de bij de cyclus uitgegeven werkboeken, een bij elk van de vier delen, is dit helder te lezen. Ik citeer uit verslagen van het werkproces:

'12/12/2002 Gesprek met de acteurs:

Guy (Cassiers) en Marc (Warning) geven uitleg over de enscenering en de vormgeving van Proust 1: De kant van Swann. Omdat het script nog niet klaar is worden de acteurs eerst geconfronteerd met de ideeën over vormgeving en de enscenering. Bij sommige acteurs komt het over alsof er voor hen niet meer zoveel te doen is: het kader en de technische machinerie (de camera's, de ruimte achter het gordijn....) liggen al vast en de acteurs moeten dat kader opvullen. Er is niet voldoende ruimte voor eigen initiatief, voor een eigen ontdekkingstocht door het decor. Guy spreekt dit tegen en wijst daarentegen op het heel open karakter van de enscenering: er staan inderdaad camera's en microfoons, maar de acteurs beslissen wanneer ze ervoor of erachter gaan staan.'

'20/12/2002 Gesprek met de acteurs:

De acteurs hebben voor het eerst het script van Proust 1: De kant van Swann gelezen. Het enthousiasme is niet erg groot. Guy is enigszins ontgoocheld, maar blijft achter het script staan zoals het in zijn totaliteit voorligt.'

\section{'13-25/1/2003 Repetities:}

De acteurs ontdekken snel de spelmogelijkheden van het decor met zijn gordijnen, camera's en microfoons. Het is even wennen aan het feit dat ze achter een gordijn staan en dat op dat gordijn hun gezicht enorm geprojecteerd wordt. Maar de (vooral komische) mogelijkheden van de mimiek worden snel uitgeprobeerd. De volwassen wereld (de ouders Marcel en Gilberte) wordt gepresenteerd als een gezicht dat uitkijkt op de twee in vergelijking kleine lichamen van Marcel en Gilberte. Het toneel is leeg, iedere beweging telt. Het wordt snel duidelijk dat het samenspel tussen muziek, tekst, licht, beeld en lichaam als een choreografie behandeld moet worden' (Kuyper, Cassiers \& Jans, 2003, p.176).

$\mathrm{Na}$ de aanvankelijke vrees van verscheidene acteurs dat ze slechts zouden worden ingezet als marionetten, bleek in de loop van het project dat deze manier van acteren eerder juist een intensivering van het acteren behelsde dan een veronderstelde devaluering. Het onderzoeken en het uitkristalliseren van het acteren met in plaats van alleen slechts voor de camera, bleek een belangrijk aspect van wat later in vakkringen een nieuwe theatertaal genoemd werd. Cassiers kwam daarbij met zijn artistieke team 
tot een inzet van live video, projectietechnieken en audiosystemen zoals nog nooit daarvoor op die schaal, met die hightechapparatuur en in die intensiteit was gedaan in theatervoorstellingen voor de grote zaal. Hij oogstte er succes mee en werd beschouwd als een van die theatermakers die als het ware het theater opnieuw aan het uitvinden waren. ${ }^{56}$ Deze verkenning van de grenzen tussen theater en technologie bij het Ro Theater werd vanaf 2006 voortgezet in Antwerpen en was mede inzet van de herstructurering van wat Toneelhuis Antwerpen ging heten.

\section{Huis van het verschil}

Het is donderdag 7 februari 2008. Op het toenmalige kantoor van Toneelhuis in de Jodenstraat te Antwerpen wacht ik tot Guy Cassiers en Erwin Jans me te woord kunnen staan. ${ }^{57}$ Ik zit op een bankje tegen een muur midden tussen de bureaus van financiële medewerkers, administrateurs, mensen van de afdeling publiciteit en anderen. Ik luister zwijgend naar een levendig gesprek tussen de aanwezigen. Het gaat twintig minuten lang over filters, camerastandpunten, technische termen voor allerlei soorten kabels en pluggen, beeldprojecties, lichtmetingen en contraststerkten. Dit gesprek had plaats kunnen vinden bij een film- of televisieproductiebedrijf, of bij een internetprovider. Ik zit echter bij een groot gesubsidieerd theatergezelschap en hoor een aantal bureaumedewerkers terloops spreken over de alledaagse artistieke praktijk van hun theaterbedrijf. Luttele minuten later komt Cassiers me glimlachend ophalen en voert me mee naar wat hij zijn bureau noemt, een lege kamer, een tafel en drie stoelen. We beginnen het eerste van een reeks gesprekken over productiewijze, repertoire, samenstelling en organisatie van Toneelhuis Antwerpen.

GC: Als we het nu over ons project hier hebben, als we dat afzetten tegen wat er in het buitenland aan de hand is in het theater, bijvoorbeeld in Frankrijk, dan is zoiets daar ondenkbaar.

$\mathrm{HH}$ : Wat is dan ondenkbaar?

GC: Het feit dat binnen die schaal waarin wij theater maken, wat toch het theatrale centrum genoemd kan worden...Dat je enerzijds kunt vertrekken vanuit verschillende kunstenaars, dat alleen al, dat die op een evenwaardige manier als verschillende artistieke lijnen naast elkaar kunnen bestaan. Dat je niet vertrekt vanuit

\footnotetext{
${ }^{56}$ Amsterdam prijs voor de kunst (2005), Werkpreis Spielzeit Europa tijdens Berliner Festspiele (2005). Op wetenschappelijke congressen in onder meer Montréal (2007), Amsterdam (2008), Brussel (2009), München (2010), Utrecht (2011) en Avignon (2008) werd de afgelopen jaren aandacht geschonken aan het innovatieve karakter van Cassiers' werk.

${ }^{57}$ In de zomer van 2008 is de hoofdvestiging van de kantoren van Toneelhuis verhuisd van de Jodenstraat naar de Orgelstraat. Dit is voor de kantoormensen dichter bij de artistieke werkplek, namelijk recht tegenover de thuisplek van het gezelschap, de Bourla schouwburg in Antwerpen.
} 
één artistieke taal, maar dat je juist de kracht van het verschil kenmerkend probeert te laten zijn voor het gezelschap, de kracht van de verschillende talen, en hoe zich dat dan in zijn geheel verhoudt tot een stedelijke context. Dat is niet evident, dat we vertrekken vanuit de kracht van het verschil.

$\mathrm{HH}$ : Heb je veel uit moeten leggen voordat je zo ver was, hier in België en bij het Ro Theater? Want jouw manier van werken is natuurlijk al veel langer gaande.

GC: De twijfel over dit project hier in Antwerpen is bij de start heel groot geweest. Men dacht dat het fenomeen gezelschap werd opgeheven in het grootste huis van Vlaanderen, wat helemaal niet mijn gevoel was, hè. Ik vind dat we hier in Vlaanderen of in Nederland niet meer kunnen denken vanuit de gedachte dat je regisseurs, acteurs en vormgevers hebt en dat je dan iemand vraagt om een tekst te schrijven, zo functioneert dat tegenwoordig niet meer. Zo heeft het heel lang gefunctioneerd, en daarin volg ik jou, dat het op heel veel plekken in stand wordt gehouden, dat systeem. Maar dat strookt niet meer met de nieuwe kunstenaar die zich aandient en met de rijkdom aan mogelijkheden dat een huis, een theaterzaal, daarmee kan hebben, over hoe die disciplines elkaar kunnen kruisbestuiven en hoe de artiesten een nieuwe dialoog aangaan met elkaar binnen een project, binnen een voorstelling en binnen een huis. En breder nog buiten dat huis. ${ }^{58}$

Toneelhuis Antwerpen koos in 2006 als leidend principe voor diversiteit, het gezelschap profileerde zich in de daaropvolgende jaren als het huis van verschil. Cassiers staat voor een werkwijze die op een organische manier zo veel mogelijk medewerkers inhoudelijk, uitvoerend en reflectief bij de totstandkoming van een voorstelling betrekt. Na zijn aanstelling als artistiek leider fungeert hij als katalysator van een schare artistieke medeconstructeurs van het theatergezelschap dat het Toneelhuis vanaf dat moment gaat worden. Het was in 2006 het grootste Vlaamse gesubsidieerde theatergezelschap en de fundamenteel vernieuwende koers was zowel gebaseerd op een zoektocht naar een ander soort theaterrepertoire als op een voor dat nieuwe repertoire noodzakelijke geachte andere organisatie van het theaterbedrijf. Men was op zoek naar de zeggingskracht van een nieuwe theatertaal, inclusief de personele consequenties daarvan, op de grens van film, performance, beeldende kunst, mode ${ }^{59}$, filosofie, dans, literatuur en wetenschap. ${ }^{60}$

\footnotetext{
${ }^{58}$ Uit de transcriptie van het interview met Guy Cassiers en Erwin Jans op 7 februari 2008 in Antwerpen. [digitaal audio bestand, timer 4.15] (transcriptie $\mathrm{HH}$ ).

${ }^{59}$ Voor de Toneelhuisvoorstellingen, Wolfskers (2007), Atropa (2008), House of the Sleeping beauties (2009) en Bloed en rozen (2010), zijn de kostuums ontworpen door en in intensieve samenwerking tot stand gekomen met de Vlaamse modeontwerper Tim van Steenbergen.

${ }^{60}$ Cassiers en de aan Toneelhuis geassocieerde theatermaker/acteur Josse de Pauw zijn een tijdlang fellows geweest van Het Platform, een Brusselse universitaire onderzoeksdenktank waar kunst en wetenschap
} 
In de nieuwe gezelschapsconstructie werd de kern van de artistieke staf vanaf de start gevormd door meerdere kunstenaars van verschillende signatuur. Het werd meer een geleid collectief van theatermakers en andere kunstenaars dan een gangbaar toneelensemble van acteurs en actrices, aangevoerd door een regisseur. Naast hun Toneelhuisvoorstellingen behielden alle aangesloten theatermakers bovendien voor een deel de vrijheid om voorstellingen of installaties te blijven maken op persoonlijke titel in andere contexten dan die van Toneelhuis. Bij de start van de onderneming sloot Cassiers een artistiek pact met choreograaf Sidi Larbi Cherkaoui ${ }^{61}$, met de door rituelen geïnspireerde Wayne Traub, met performancekunstenaar Benjamin Verdonck, met de jonge Nederlandse regisseur Lotte van den Berg, met het Vlaamse theatercollectief Olympique Dramatique en met videokunstenaar en scenograaf Peter Missotten van De Filmfabriek. ${ }^{62}$ Dit zijn de facto zeven artistieke kernen, zeven culturele systemen van verschillende snit in één huis. Allen 'nieuwe kunstenaars', in termen van Cassiers, met interesses en talenten in meer dan één discipline.

Missotten was 'besmet' door de filmwereld, door de opera en de beeldende kunst, Traub was naast theatermaker ook filmer en musicus, Van den Berg kwam uit de Nederlandse mimewereld en koesterde filmambities, Verdonck was opgeleid als acteur maar werd in zijn werk sterk beïnvloed door performancekunstenaars uit de beeldende kunsttraditie en Cassiers zelf was ook een gewild operaregisseur. Het feit dat deze theatermakers in hun werk aanpalende kunstendisciplines raakten, maakte hen voor de nieuwe opzet van het gezelschap en voor een artistieke visie gebaseerd op de dramaturgie van het verschil interessant. Tegelijkertijd leerden deze kunstenaars om op de schaal van het grote theaterhuis van de Bourla schouwburg na te denken over wat erbij komt kijken om met een theatervoorstelling een zo groot mogelijk publiek te bereiken, iets waar ze in het kleinezalencircuit ook over hadden moeten nadenken. In de officiële aanvraag van het gezelschap voor de vierjarige rijkssubsidie van het Vlaamse Ministerie voor Cultuur, Jeugd, Sport en Media wordt het in 2008 als volgt geformuleerd:

'De maker wordt in deze constellatie gedefinieerd als een nieuw, eigentijds type van podiumkunstenaar dat niet langer omschreven kan worden in termen van regisseur of acteur. Wat de 'maker' kenmerkt, is een eigen wereldbeeld en

\footnotetext{
elkaar treffen in onderzoeksprojecten op doctoraatsniveau. De ingewikkelde relatie tussen kunst, politiek en macht was er onderwerp van debat en onderzoek.

${ }^{61}$ Naar aanleiding van zijn choreografie/voorstelling Sutra (2008) wordt Cherkaoui in 2008 door het vooraanstaande internationale danstijdschrift Ballett-Tanz uitgeroepen tot Choreographer of the Year. Hij creëerde de voorstelling samen met beeldend kunstenaar Antony Gormley, componist Szymon Broska en monniken van de Chinese Shaolin-tempel. Het werd geproduceerd door het Sadler's Wells Theatre uit Londen.

${ }^{62}$ Van alle zeven hier genoemde theatermakers staan biografieën in Toneelg(e)ruis (Jans, 2007b).
} 
theatertaal; hij of zij is nog vrij jong, maar heeft al een artistiek parcours afgelegd. Deze invulling heeft ingrijpende consequenties voor de organisatie: de artistieke autonomie van de makers, hun diversiteit en de aanwezigheid van verschillende disciplines bepalen de werking van Toneelhuis op alle niveaus, dramaturgisch, productioneel, technisch, promotioneel en financieel' (Toneelhuis, 2008, p. 7).

Dit breed gevoelde veranderingsproces rond werkwijze en te spelen repertoire werd bij de drie vergelijkbare grote gezelschappen in Vlaanderen in de jaren 2000-2010 op verschillende manieren vormgegeven. In Brussel zoekt de Koninklijke Vlaamse Schouwburg (KVS) het vooral in zorgvuldig gekozen literair dramatisch repertoire rond het thema van culturele diversiteit in de grote steden; in Gent (NTGent) wordt gewerkt aan eigentijdse varianten van ensemblevorming in een internationale artistieke context en bij Toneelhuis gaf men vorm aan het experiment van een periodiek wisselende groep van regisseurs, kunstenaars, performers en scenografen. ${ }^{63}$ Cassiers nodigt zijn collega's van binnen het eigen gezelschap zowel als die van de andere Vlaamse en Nederlandse grote gezelschappen voortdurend uit om deze diversiteit met elkaar op te zoeken, te bevragen en te begrijpen. Het is in zijn beleving de essentie van het leren omgaan met de manier waarop dit in het werkelijke leven ook zou moeten gebeuren. Volgens Cassiers communiceren de verschillende kunstenaars onder één dak verrassend goed met elkaar, juist vanwege de verschillende wereldbeelden.

GC: Door een constellatie te organiseren waarbinnen ze zowel hun verleden verder kunnen ontwikkelen als wel dat verleden kunnen combineren met een aantal nieuwe ideeën in een context op een andere schaal om met een aantal nieuwe opties stappen verder kunnen zetten. Tegelijkertijd zijn wij een soort geconcentreerde miniatuur van wat een stad kan of mag zijn. Dat is van....hoe probeer je samen te leven. Want hoe communiceren die mensen, hoe doen die collega-kunstenaars dat met elkaar? In eerste instantie niet via hun artistieke werk. Dat is in de eerste instantie vanuit de organisatie, vanuit wanneer we een boterham eten tezamen.

$\mathrm{HH}$ : Juist.

GC: Van hoe laat beginnen we? De praktische zaken genereren het eerste contact en natuurlijk hebben we samen gepraat over waar we naartoe willen en waar we voor staan. Maar in de praktijk is het eerste waarmee je geconfronteerd wordt het praktische. Soms wordt onderschat wat het belang daarvan is. De omstandigheden waarin mensen werken zijn heel belangrijk en de ruimte die gecreëerd wordt is heel belangrijk om een artistiek gesprek zinvol te laten zijn en op termijn de interactie, want het is niet voor niks dat we vertrekken vanuit verschillende disciplines, dat mensen

\footnotetext{
${ }^{63}$ Gesprek met Erwin Jans op donderdag 23 april 2009 in Antwerpen.
} 
staan voor een totaal andere lijn, waardoor, zeg maar, de reflectie over elkaars werk makkelijker wordt, raar genoeg. ${ }^{64}$

In de zomer van 2011 koos Toneelhuis er na vijf jaar voor om per 2013 toch weer voor een klein deel terug te keren naar de ensemblestructuur van vóór 2006. Niet omdat men terugkwam op de ingeslagen koers, maar om ook met enkele acteurs en actrices onder contract nog weer een andere kleur te kunnen toevoegen aan het palet van het gezelschap. Waar in vorige subsidiedossiers nog sprake was van een ensemble van makers staat in de Aanvraag van een meerjarige subsidie voor het geheel van de werking 2013-2016 nu ensemble van makers \& spelers (Toneelhuis, 2011, p. 11). Het Mission Statement van de organisatie is als volgt omschreven:

'Toneelhuis ziet zichzelf als een artistieke microsamenleving die theater van nu over nu maakt. (...) Toneelhuis bevindt zich in het centrum van het podiumkunstenlandschap, maar zoekt ook welbewust vernieuwing en experiment op. Toneelhuis definieert zichzelf sinds 2006 als een 'ensemble van makers'. Vanaf 2013 wordt Toneelhuis 'een ensemble van makers en spelers'. De onderlinge artistieke verschillen tussen de makers en de aanwezigheid van verschillende artistieke disciplines blijven de creatieve motor van het huis. In een persoonlijke, eigentijdse theatertaal gaan de Toneelhuismakers op zoek naar enthousiasmerende, kritische en alternatieve manieren om met de werkelijkheid om te gaan. Een veelheid van antwoorden op de complexe werkelijkheid van vandaag. Nieuw is dat, met ingang van beleidsperiode 2013-2016, een vaste acteurskern de makersploeg vervoegt. Deze acteurskern staat garant voor continuïteit en herkenbaarheid voor het publiek over de verschillen heen. (...) Met deze artistieke diversiteit wil Toneelhuis de hand reiken aan een breed en gediversifieerd publiek' (Toneelhuis, 2011, p.8).

De gedeeltelijke terugkeer naar de ensemblestructuur had volgens Cassiers te maken met de toenemende samenwerking met Toneelgroep Amsterdam en andere Europese gezelschappen, waarbij het probleem rees van het gemis aan vaste spelers bij hernemingen van succesvolle voorstellingen, en met het feit dat een deel van het publiek zich beter bleek te kunnen identificeren met spelers van vlees en bloed dan met het voor de meeste mensen toch abstracte begrip theaterkunstenaars. Toneelhuis handhaaft de notie van het artistieke verschil en van het maatschappelijke belang van een perspectief dat uitgaat van verschil. Vanuit de verscheidenheid aan disciplines en artistieke fascinaties worden maatschappelijke kwesties als macht, interculturaliteit en

\footnotetext{
${ }^{64}$ Uit de transcriptie van het interview met Guy Cassiers en Erwin Jans op 7 februari 2008 te Antwerpen [digitaal audio bestand, timer 19.35] (transcriptie HH).
} 
verstedelijking gethematiseerd. De structuur en de werking van het gezelschap als geheel kunnen gezien worden als metaforen voor de dynamische werking van een stad, maar dan op schaal, als een miniatuurstad. Toneelhuis wenst de Antwerpse samenleving buiten zijn thuishaven, de Bourla schouwburg, te spiegelen.

\section{Artistieke emancipatie van theatertechnici}

De zoektocht naar een eigentijdse taal op de grens van technologie en theater heeft veel impact gehad op de technische staf waar Cassiers mee werkte. Toen hij in Antwerpen begon, moest hij met de technici van het bestaande Antwerpse theatergezelschap helemaal opnieuw beginnen om te komen tot een zelfde artistiek technologisch niveau in vergelijking met zijn ploeg van het Ro Theater in Rotterdam. Theatervormgever, lichtontwerper en videotechnicus Arjen Klerkx, een van de technici die het proces met Cassiers bij het Ro Theater nagenoeg vanaf het begin heeft meegemaakt, beaamt dat in ons gesprek in alle toonaarden. ${ }^{65}$

AK: Ik wou heel graag bij Guy terechtkomen, ik wou heel graag voorstellingen maken, maar dat kon niet want er bestond een tweespalt. Ik deed heel veel bij Guy, ook inhoudelijk, maar ik stond altijd aan de dienende techniekkant en op een gegeven moment had ik daar onvrede mee. Ik zet me heel erg in, word heel erg bij het maakproces van de voorstelling betrokken, maar ik bleef toch onder de afdeling techniek vallen.

$\mathrm{HH}$ : Dus ontwerper, schepper of dienend technicus?

AK: Ja, dat wringt dan bij mij. Op een gegeven moment ging Guy dus weg naar Toneelhuis en ik kon twee dingen doen. Ik kon blijven bij het Ro Theater maar dan zou ik lichttechnicus worden omdat video totaal niet meer in beeld zou zijn daar, maar ik had een specialisatie opgebouwd van acht jaar. Het andere was om naar Guy te gaan maar ik was toen bang dat ik weer in een zelfde soort proces terecht zou komen.

$\mathrm{HH}$ : Nou, hij zegt dat hij in Antwerpen min of meer opnieuw moest beginnen. AK: Ja, dat klopt.

\footnotetext{
${ }^{65}$ Arjen Klerkx is vanaf begin jaren negentig als technicus/video-ontwerper betrokken bij het werk van Guy Cassiers. Eerst als medewerker van het Ro Theater en na de overstap van Cassiers naar het Toneelhuis als freelancer. Hij besloot niet mee te gaan naar Antwerpen omdat hij opzag tegen het herbeginnen aan het vormingsproces van een team technici 'van de nieuwe soort' en in Rotterdam blijven vond hij op dat moment ook geen optie omdat hij dan weer 'gewoon' lichttechnicus zou zijn. Als freelancer zet hij zich nu in alle vrijheid op diverse plekken in om vorm te geven aan nieuwe theatertalen op de grenzen van lichtontwerp, audiovisuele technologie, scenografie, film, projectie en dramaturgie. Zowel in de gesubsidieerde circuits van Nederland en Vlaanderen als in het commerciële Europese circuit van groots gemonteerde musicals.
} 
$\mathrm{HH}$ : Hij moet daar nog zoeken naar de chemie en zit daar nog midden in, denk ik, dat kun jij beter beoordelen, hij vindt dat organisch bij het proces horen, hij calculeert dat in. Je zou dan inderdaad weer met een ploeg ongeveer hetzelfde proces meemaken.

AK: Ja, klopt, maar drie ontwerpers die eigenlijk bij het Ro Theater waren, Diederik [de Cock HH], Enrico [Bagnoli HH] en ik, zijn meegegaan met Guy, maar wel in een andere functie. Ik ga niet meer terug als technicus naar Toneelhuis.

$\mathrm{HH}$ : En die andere twee, hebben die ook een andere functie?

AK: Nou, Enrico was altijd al lichtontwerper en Diederik was eigenlijk geluidstechnicus maar die is nu ook geluidsontwerp gaan doen. Maar we zaten al in die stroming, hè. Het is een naampje bij iets, maar voor ons was het een compleet ander gevoel.

$\mathrm{HH}$ : En jullie staan ook heel anders in dat vak dan de gemiddelde technicus die al, laat ik zeggen, twintig, dertig jaar in dat vak zit, wat Guy nu meemaakt met de mensen in het oude gezelschap...

AK: Ja, precies.

$\mathrm{HH}: . .$. en dat zouden dan in het beste geval dialogen moeten zijn.

AK: Ja, dat is zo. En toen ben ik dus voor mezelf begonnen. Je springt in het diepe, ik ging freelancer worden, ik ging mezelf neerzetten als video-ontwerper.

HH: Zzp'er? ${ }^{66}$

AK: Precies, het is goed bevallen moet ik zeggen, bevalt nog steeds goed. ${ }^{67}$

Een aantal technici groeide in het innovatieproces van Cassiers' hightechtheater langzaam in een nieuwe rol, andere konden de omslag niet zo snel maken. In Antwerpen zijn veel technici van de oude stempel vertrokken, voor hen in de plaats zijn veelal jonge technici gekomen die speciaal voor de nieuwe aanpak gekomen zijn. Technici van het eerste uur, Klerkx, Bagnoli en De Cock, hebben zich dan inmiddels ontwikkeld tot gelijkwaardige artistieke gesprekspartners in het intermediale productieproces dat het maken van theater werd onder Cassiers, niet uitsluitend in samenwerking met hem, maar ook met een aantal andere theatermakers van Toneelhuis Antwerpen. In navolging van Uri Rapaport is deze ontwikkeling de artistieke emancipatie van de theatertechnicus te noemen (Fischer, 2006, pp. 228-236).

In de denktank rond Cassiers vinden vaktechnische discussies plaats die horen bij de ontwikkeling van een nieuwe theatertaal. Een van die discussies is die tussen de

\footnotetext{
${ }^{66}$ Zzp staat voor zelfstandige zonder personeel, en is een Nederlandse aanduiding voor een beroepsstatus die vroeger freelance werd genoemd. Men kan ook spreken van een eenmanszaak of van zelfstandig ondernemerschap.

${ }^{67}$ Uit de transcriptie van het interview met Arjen Klerkx op 18 oktober 2008 te Amsterdam [digitaal audio bestand] (timer 20.55) (transcriptie H.Havens).
} 
'makers van de plaatjes' (videokunstenaars, filmers, beeldend kunstenaars) en de theaterspecifieke uitvoerende lichttechnici. Klerkx ziet een duidelijk verschil tussen de nieuwe rol van de technicus en de opvattingen van theatertechnici van de oude stempel, die ervan uitgaan dat de plaatjesmakers in het theaterproductieproces hun materiaal uit handen geven aan de echte theatermensen, aan de traditionele lichttechnici. Het uit handen geven betekent dan vaak ook zoveel als overleveren aan een andere smaak en andere compositieopvattingen dan oorspronkelijk bedoeld door de beeldontwerpers. Projectie kan tegenwoordig erg groot bewerkstelligd worden, haarscherp en conform realistische weergaveconventies. Maar onvoltooid, niet perfect, rafelig gekaderd, korrelige resoluties of vlekkerig geprojecteerde weergaves kunnen bewuste keuzes zijn voor de scheppers van content. Dit past soms niet in het denkraam van meer traditioneel ingestelde lichttechnici. Klerkx, Missotten, Rapaport en andere min of meer gelijkgestemde geesten zijn wat dit aangaat geëmancipeerd, ze stellen dat het nodig is om als video-expert en schepper van content, flexibel te zijn tot en met het daadwerkelijk toonmoment in de voorstelling. Klerkx vergelijkt de noodzaak van flexibiliteit met die van bijvoorbeeld de roadie/geluidstechnicus in het midden van de zaal bij concerten van popgroepen en rockbands: vanuit de zaal ademen zij mee met de musici op het podium. Dat zou ook zo kunnen of zelfs moeten in voorstellingen op de grens tussen theater, video, film en literatuur, zoals Cassiers die maakt. De techniek staat hier uitdrukkelijk niet alleen ten dienste van een theatertraditie met bijbehorende dienende disciplines als lichttechniek, decorontwerp, etc. Maar technologische experts worden onderdeel van een artistiek aansturend team, die vanuit hun geëmancipeerde status in voorstellingen meeademen met de performers, acteurs en dansers, om zo een actieve rol te spelen in voorstellingen.

\section{Nieuwe theatertaal: zintuigen openzetten}

Cassiers' fascinatie voor technologische toepassingen is niet alleen van invloed op de productiewijze van de voorstellingen van Toneelhuis Antwerpen en op de samenstelling van het gezelschap maar de invloed van technologie wordt in de voorstellingen ook bevraagd. Cassiers gaat uit van het idee dat de werkelijkheid buiten het theater geperverteerd is door media.

GC: Dat is een ander aspect. Dat is de invloed van de technologie: waarom breng je dat allemaal op de scene, die materie? Dat vragen mensen zich soms wel af. Voor mij heeft dat te maken met dat ik daar buiten dat theater steeds meer geconfronteerd word, met een taal die wij dag in dag uit hanteren. En ondanks het feit dat ik daar zo ver mogelijk vanaf probeer te blijven staan, voel ik buiten het theater wel de impact dat het op mij heeft. Hoe ik denk, hoe ook ik daarmee omga, hoe ik zelf mijn wereld 
probeer te construeren en daar is het indirecte een heel belangrijke factor bij. Over hoe wij communiceren buiten het theater, dat is steeds meer, allez, dat niet meer zoveel mensen echte gesprekken voeren, zoals wij hier nu, een op een. En via de media voel je dat ook steeds meer dat het niet meer gaat over wat je vertelt maar vooral van hoe dicht kom je bij de inhoud, hoe geraak je bij de inhoud en bij hetgeen je nodig hebt. Maar het incorporeren van inhoudelijk materiaal, dat is steeds minder een noodzaak en dat vind ik heel gevaarlijk.

$\mathrm{HH}$ : Waarom is dat steeds minder een noodzaak?

GC: Omdat ik denk, dat voel ik bij mijn neefjes, ja, alle informatie is beschikbaar voor ze. Wat dan ook, alles, je kunt het op het net vinden.

$\mathrm{HH}$ : Jij houdt zo rekening met de manier waarop mensen informatie tot zich nemen, coderen en decoderen?

GC: Wat ik merk aan mezelf. Als ik in de stad rondloop krijg ik zoveel informatie over mij heen, zodat ik ga denken dat wij vooral fysiek geconditioneerd worden om weg te laten, om vooral onze zintuigen niet te gebruiken. En dat is voor mij steeds meer richtinggevend, ik gebruik heel graag die elementen van de straat buiten het theater, breng dat dan in het theater in, maar doe daar dan het tegenovergestelde mee, hopelijk, als het goed gaat. Om dan juist de zintuigen van de toeschouwers terug weer open te kunnen zetten. En vanuit het isolement dat je terug je lichaam gebruikt in al zijn facetten van wat het kan. Maar waar we niet meer onze zintuigen echt gebruiken, allez, we gebruiken onze oren bijna alleen nog voor apparaten, voor het grootste deel proberen we er oordopjes in te steken en we zetten zonnebrillen op om ons te isoleren. ${ }^{68}$

In zijn poging om de zintuigen van het publiek opnieuw te openen vindt Cassiers aansluiting bij het werk van de Russische kunstenaar Andrej Tarkovski (1932-1986), filmmaker, schrijver, fotograaf en theoreticus. Hij is een van Cassiers' belangrijke inspiratiebronnen in zijn gefascineerdheid voor traagheid en tijd als koppelingen tussen verleden, heden en toekomst.

'Het werk van Tarkovsky betekent zeer veel voor mij, zowel zijn films als De Verzegelde tijd, een filosofische essay over zijn manier van creëren en over het belang van kunst en de kunstenaar in de maatschappij. Het religieuze aspect daarvan interesseert mij minder maar zijn gedachten over kunst en tijd - tijd in al zijn gedaanten - zijn voor mij van onschatbare waarde. Zijn film Stalker heeft mij indertijd als student compleet overhoop gehaald, zowel door zijn inhoud als door zijn vorm. In die film speelt hij heel erg met tijd. Hij vervormt die tijd dusdanig dat

\footnotetext{
${ }^{68}$ Uit de transcriptie van het interview met Guy Cassiers en Erwin Jans op 7 februari 2008 te Antwerpen [digitaal audio bestand, timer 50.00] (transcriptie $\mathrm{HH}$ ).
} 
het begrip tijd ophoudt te bestaan. Dat kom je bij Proust ook tegen. Hoe je vanuit het verleden dat je meedraagt een toekomstperspectief kunt genereren. Zowel Proust als Tarkovsky proberen de mogelijkheden van de zintuigen maximaal aan te scherpen, niet alleen voor zichzelf maar ook bij de toeschouwers' (Kerkhoven, 2007). ${ }^{69}$

Tarkovski behoort tot de grote visionaire filmmakers van de twintigste eeuw. In zijn films legt hij getuigenis af van zijn poëtische visie op het leven en op de positie, de rol en de verantwoordelijkheid van de kunstenaar (Tarkovski, 2007). De manier waarop in zijn films verschillende disciplines als verschillende talen, of in Even-Zohars termen sprekend, als verschillende cultuursystemen, samengaan, is voor Cassiers en de zijnen een voorbeeld van artistieke synergie. Soms worden woorden uitgesproken als een voice-over, meer of minder synchroon lopend met de beelden. Soms naderen beeld, handeling, woord en muziek elkaar, soms lijken ze weinig of niets met elkaar te hebben en soms vloeien ze ineen met respect voor de verschillende media of disciplines. Zo kan Tarkovski's idioom metaforisch staan voor de werking van de verschillende talen van de theatermakers van Toneelhuis Antwerpen. Die communicatie tussen regisseur en toeschouwers verloopt in een traagheid die in onze beleving van de dagelijkse werkelijkheid nauwelijks meer bestaat, terwijl een dergelijke traagheid toeschouwers zowel als kunstenaars in staat stelt gezamenlijk een sensorisch intense gebeurtenis te beleven.

Naast Prousts romancyclus $A$ la recherche du temps perdu ensceneerde Cassiers nog meer werk van schrijvers, zoals dat van Jeroen Brouwers, Bernlef en Hugo Claus. In 2009 volgde Malcolm Lowry's Under the Volcano en in seizoen 2008-2009 begon hij met de voorbereiding voor zijn theaterbewerking van de omvangrijke roman De Man zonder eigenschappen van Robert Musil. ${ }^{70}$ Deze literaire werken bezitten een onmiskenbaar traagheidsaspect. Bij Toneelhuis zette men deze traagheid in die periode centraal in zijn theatertaal, daarbij in de regel gebruikmakend van veel technologische toepassingen. Toeschouwers herkennen de technologie uit hun dagelijkse gemediatiseerde werkelijkheid: microfoons, camera's, beeldschermen, split screens, projecties van immense afmetingen en indringende soundscapes. Hierdoor wordt geprobeerd om enerzijds aansluiting te vinden bij de eigentijdse belevingswereld van het publiek om er anderzijds steeds net buiten te treden. We communiceren inderdaad massaal via televisie, computers, smartphones, iPods en

\footnotetext{
${ }^{69}$ Cassiers geciteerd in een voorbeschouwing door Marianne van Kerkhoven bij de Toneelhuisvoorstelling Wolfskers in Bulletin Kaaitheater (nov/dec 2007), het informatiemagazine van het Kaaitheater te Brussel (Kerkhoven, 2007).

${ }^{70} \mathrm{Hij}$ bewerkte de roman voor theater in drie delen, die alle drie afzonderlijk hun première beleefden. In juni 2012 werden de delen I, II en III voor het eerst samen, in een theatermarathon, opgevoerd.
} 
iPads, maar ook door het dragen van zonnebrillen, grote petten en andere identiteitsverhullende of -bevestigende accessoires. Het is in de ogen van Cassiers of de westerse mens zich aan de ene kant constant wil verbinden met de rest van de wereld en zich anderzijds paradoxaal genoeg tegelijkertijd wil afschermen van het mediabombardement dat hij dagelijks over zich heen krijgt. In het theater wil Cassiers diezelfde media inzetten om ze als het ware een kwartslag te draaien en anders te gebruiken, om ze publiekelijk te bevragen. Tijdens theatervoorstellingen wil hij de zintuigen van het publiek weer prikkelen om reflectie op schoonheid, op traagheid, op de impact van beelden en de relatie daarvan met de eigen werkelijkheid, te stimuleren. De strategische bedoeling is dat er op den duur gewenning aan intercultureel en intermediaal vernieuwende artistieke concepten plaatsvindt. Als deze opzet op termijn slaagt, zal er geleidelijk een steeds grotere publieke ruimte ontstaan om met elkaar te communiceren, om elkaars verhalen te bekijken en beluisteren.

Sommige van de Toneelhuiskunstenaars stuiten in hun onderzoek naar een nieuwe theatertaal op onbegrip bij een publiek dat vreemd staat tegenover hun weerbarstigheid of verstilling. Een expliciet voorbeeld van zo'n weerbarstige Toneelhuisvoorstelling was Winterverblijf, een voorstelling van Lotte van den Berg in seizoen 2007-2008. In een van de interviews verwoordde dramaturg Erwin Jans deze confrontatie als volgt:

EJ: Het kan ook clashen, hè. Winterverblijf was daar een goed voorbeeld van. Lotte die haar eerste voorstelling maakte in de Bourla, voor de grote zaal, ja, daar merkten we heel snel dat de communicatie met dat publiek heel moeizaam verliep. Omwille van haar dwingende esthetica. Heel erg gericht op dat observeren, er gebeurt niet zo veel, grote verstilling, ja, dat is iets wat dan het publiek niet verwacht had of daar toch maar even op zat te kijken. Dus dat was een voorstelling die voor een gedeelte heel erg is gesmaakt, een deel van het publiek zegt ja, dat is een heel belangrijke voorstelling, wij vonden dat ook. Dat gaat ver, dat zegt veel over wat theater eigenlijk is, dat zit om een nulpunt, opnieuw. En een ander deel van het publiek is daar compleet op afgehaakt, heel boos ook geworden. Dus dan merk je dat zo'n dialoog ook wel kan vastlopen.

$\mathrm{HH}$ : Maar dat is het hele idee van een dialoog, natuurlijk.

GC + EJ: Ja, natuurlijk.

EJ: Maar we zijn er wel een beetje van geschrokken.

$\mathrm{HH}$ : Van die heftigheid?

EJ: Ja, van die heftigheid. We hadden wel verwacht, dat is niet evident, dat hadden we gezien bij de repetities al van een echte Lotte-voorstelling, maar precies door ze dan in zo'n plek met zo'n grote sociale en symbolische waarde te plaatsen....

GC:...krijgt het een ander karakter. 
EJ: Wordt het iets anders. Het had misschien in de Monty ${ }^{71}$ moeten staan, daar zit de avant-garde, daar weten mensen hoe ze moeten....

$\mathrm{HH}$ : Maar daar is het preken voor eigen parochie.

GC: Ja, juist, natuurlijk.

$\mathrm{HH}$ : En kleiner en beschermd, maar dit is een confrontatie.

GC: Maar daarom merk je binnen de extremen die we dikwijls opzoeken in onze voorstellingen, dat het begeleiden naar en het verwerken van voorstellingen belangrijk is.

$\mathrm{HH}$ : Maar dat is nu bijna het opzoeken van een grens, het scherp van de snede, van waar zit die eigenzinnige eigenheid van de kunstenaar en waar zoekt hij mogelijkheden om met die eigenzinnigheid bij een groter publiek terecht te komen.

GC: Ja, dat je trajecten met een publiek afloopt. Ik denk als ik in Rotterdam met, ik had het ook niet gekund, maar met de Proust was begonnen in het Ro Theater, dat het een heel andere impact had gehad dan dat ze mijn werk na vijf jaar leren kennen en dan die stap naar Proust zetten.

$\mathrm{HH}$ : Ja, juist.

GC: Het is ook een reis die je onderneemt met je publiek. ${ }^{72}$

Winterverblijf was Van den Bergs eerste voorstelling voor de grote zaal. Het stuk begint met het afspelen van een band waarop te zien is dat haar vader besluit te stoppen met theater om zich te gaan wijden aan het geloof. De voorstelling verwijst naar een gebeurtenis die ook werkelijk heeft plaatsgevonden in 1987. In dat jaar kondigde de destijds beroemde Nederlandse poppenspeler Jozef van den Berg op het podium van De Singel in Antwerpen zijn vertrek uit het theater aan. Hij kon, naar eigen zeggen door de confrontatie met de ongeneeslijke ziekte van zijn broer, niet meer omgaan met de onechtheid van theater. ${ }^{73} \mathrm{Hij}$ stelde zich vragen over de werking van theater, over de relatie tussen werkelijkheid en waarheid. De Nederlandse regisseur Jan-Joris Lamers tekende voor het toneelbeeld van Winterverblijf en heeft een groot aandeel gehad in de nietsontziende kaalslag waar het de handeling van de voorstelling

\footnotetext{
${ }^{71}$ De Monty is een bekende kleinere theaterzaal in Antwerpen met een overwegend kritisch en geëngageerd publiek.

${ }^{72}$ Uit de transcriptie van het interview met Guy Cassiers en Erwin Jans op 13 juni 2008 te Antwerpen [digitaal audio bestand] (timer 16.49) (transcriptie H.Havens)

${ }^{73}$ Zelf heb ik de voorstelling van Lotte van den Berg niet gezien. Ik baseer me voor mijn opmerkingen en conclusies over deze veelbesproken voorstelling op een gepubliceerd vraaggesprek van Van den Berg met dramaturg Erwin Jans, 'Een beginpunt, een eindpunt, in elk geval een keerpunt' (Jans, 2008, pp. 92-97) en op het beschouwende artikel van de hand van Arthur Sonnen, 'Een voorstelling uit het hiernamaals'. Sonnen schrijft over de onontkoombare relatie tussen het theateridioom zoals Lotte van den Berg dat hanteert in Winterverblijf en de theatertheoretische erfenis van de Nederlandse theaterpedagoog, regisseur en acteur Jan Joris Lamers (Sonnen, 2008, pp. 98-102).
} 
betreft. Er was muziek van twee zangeressen, de boventoonzangeres Sainkho Namtchylak en de alt Judith Vindevogel en acteur Dirk Roofthooft sprak de authentiek historische tekst uit van Jozef van den Berg over de onmogelijkheid van toneel. De actrices Marij Verhaevert en Marlies Heuer hadden een ondergeschikte rol. Ingevoerde specialisten begrepen een aantal van de gemaakte keuzes, een groot deel van het publiek voelde zich echter geschoffeerd. Sommige toeschouwers verlieten de zaal.

Investeren in technologie, onderzoek en internationale samenwerking

Het vormgeven van de artistieke ambities van Toneelhuis Antwerpen heeft de afgelopen jaren niet alleen grote gevolgen gehad voor de samenstelling van de artistieke staf en voor de dramaturgische en theatrale strategieën die zij hanteert, maar ook voor de dagelijkse organisatorische bedrijfsvoering en structuur van het gezelschap als geheel. De artistieke koersverandering valt af te lezen aan cijfers over de personele bezetting. Het is belangrijk te beseffen dat het hier om een momentopname gaat (2008), deze cijfers zullen op moment van verschijnen van dit boek op verschillende punten wellicht anders zijn. Mij gaat het om de grote lijnen van de opzet sinds de structuurverandering van 2006.

Directie

Ensemble van Makers

Artistieke coördinatie

Interne organisatie

Dramaturgie en Publiekswerking

Externe relaties

Planning en Productie

Techniek

Financiën en personeel

Onthaal schouwburg

Catering

(Raad van bestuur

(Toneelhuis Antwerpen, 2008)

\section{2}

7

1

2

3

8

9

30

4

9

4

16)

Wat direct in het oog springt, is het aantal van dertig technici. Dit is voor het eerste decennium van de 21 e eeuw relatief groot. ${ }^{74}$ Volgens Cassiers behoren de voorstellingen van Toneelhuis tot de duurste producties van het Vlaamse theater.

\footnotetext{
${ }^{74}$ Ter vergelijking: in seizoen 2003-2004 maakten twintig licht-, decor-, en geluidssontwerpers, van wie de meesten tevens uitvoerenden, deel uit van het tableau de la troupe van theatergezelschap ZT Hollandia te Eindhoven, een van de grotere gesubsidieerde gezelschappen van Nederland van dat moment.
} 
$\mathrm{HH}$ : Is het duurder? Gewoon...de constructie, technologisch, ik bedoel, Wayne Traub, Peter Missotten, jij zelf.

GC: Dat zijn inderdaad voorstellingen die nergens in Vlaanderen zo duur gebudgetteerd worden, denk ik.

$\mathrm{HH}$ : Ja, dat bedoel ik.

GC: Dat is gewoon zo.

$\mathrm{HH}$ : Is dat uit leggen? Inmiddels wel, natuurlijk.

GC: Ja, maar ik denk omdat wij bijna nog de enigen zijn die investeren in een geluidstechniek of in een geluidsconcept, wat bij ons evenwaardige disciplines zijn. Hoeveel keer doet een technicus tegelijkertijd óók het lichtontwerp en dergelijke, dat doet niks af aan het feit dat daar ook heel goede dingen uit voort kunnen komen. Maar al die functies worden bij anderen in mekaar geschoven, vaak om budgettaire redenen. Ik vind juist dat wij als groot huis respect moeten hebben voor al die verschillende functies.

$\mathrm{HH}$ : Je moet uit kunnen pakken.

GC: Als het grootste huis dat niet doet, wie dan wel? En in dat opzicht moet ge toch ook, vind ik, respect hebben voor die disciplines die samenkomen op de scene. En wat in Duitsland, allez, in elk theater gebeurt. Als er hier geen enkel theater dat nog zou doen, omwille van het feit maar-de-anderen-doen-dat-toch-ook-niet, dan trek je alles gewoon naar beneden.

$\mathrm{HH}$ : Dus soms duurder, soms niet. Het maakt dus niet zoveel uit?

GC: Het is niet duurder als je het bekijkt als investering. Onze eerste twee seizoenen hebben heel veel geld gekost. Maar je moet ook durven investeren vind ik.

HH: Oké.

GC: Maar daar waren zeker nu nog niet de middelen voor. Waar wij vooral in hebben geïnvesteerd is in mensen, in eerste instantie en in bijvoorbeeld een internationaal beleid. ${ }^{75}$

De meerkosten van de voorstellingen worden niet alleen bepaald door het aantal technici maar laten zich ook verklaren doordat Cassiers veel investeert in state-of-theart theatertechnologie en in deskundigheidsbevordering voor de ploeg van technici, het inkopen van kennis en het in dienst nemen van specialisten. ${ }^{76}$ Het is volgens technicus Klerkx een troost dat technologische apparatuur met het jaar goedkoper

\footnotetext{
${ }^{75}$ Uit de transcriptie van het interview met Guy Cassiers en Erwin Jans op 13 juni 2008 te Antwerpen [digitaal audio bestand] (timer 36.00) (transcriptie H.Havens).

${ }^{76} \mathrm{In}$ : Aanvraag voor een vierjarige subsidie voor het geheel van de werking door Toneelhuis Antwerpen bij het Vlaams Ministerie voor Cultuur, Jeugd, Sport en Media van 15 september 2008. pag.28, is te lezen: 'Dit nieuwe model vroeg om een nieuw organigram, en vaak per functie of functiegroep om nieuwe taakomschrijvingen (om maar één voorbeeld te noemen: een aantal artistieke trajecten vragen om meer specialistische technici, eerder dan generalistische).'
} 
wordt. Toneelhuistechnici kijken regelmatig naar wat er bij de grote stadionconcerten van Madonna, U2, Coldplay of andere popgrootheden op en rond de podia gebeurt. Ze leven in de wetenschap dat de daar gebruikte audio- en videotechnologie over bijvoorbeeld vijf of tien jaar ook op schaal in de theaters beschikbaar komt. Vak- en kennisontwikkeling, zelfs bij voorkeur los van het artistieke scheppingsproces van een bepaalde productie, lijkt Klerkx een noodzaak om de nieuwe theatertaal verder door te ontwikkelen in ingeslagen richtingen, zo liet hij weten in ons vraaggesprek (A. Klerkx, 18 oktober 2008).

In het dossier voor de aanvraag van een meerjarige subsidie voor 2010-2013 bij de Vlaamse overheid formuleerde Toneelhuis al dat er contacten waren met gespecialiseerde technologische onderzoeksinstituten op basis van open innovatiesystematiek. ${ }^{77}$ Twee Vlaamse onderzoeksinstituten stonden in dit verband als volgt genoemd in de subsidieaanvraag voor 2010-2013:

'IBBT. Interdisciplinair Instituut voor Breedband Technologie is een onafhankelijke onderzoeksinstelling die in opdracht van de Vlaamse overheid innovatie binnen ICT stimuleert. Het IBBT-team biedt bedrijven en organisaties actieve ondersteuning bij onderzoek en ontwikkeling en brengt uiteenlopende bedrijven, overheden en non profit organisaties samen rond onderzoeksprojecten. Bij elk van die projecten komen zowel technische als niet-technische aspecten aan bod.

(...)

EDM. Expertise centre for Digital Media, het researchinstituut van de Universiteit van Hasselt, en actief in ICT sinds 1987. EDM werkt met een zeventigtal specialisten in fundamenteel en toegepast onderzoek. Het onderzoek situeert zich in drie competentievelden: computergrafiek, mens-computer-interactie, en multimedia \& communicatietechnologie. Aan dit EDM, dat al vaker heeft samengewerkt met theaterinstellingen, werden voor de voorstelling Onder de vulkaan en voor de Musilcyclus concrete onderzoeksopdrachten geformuleerd in verband met de ontwikkeling van bepaalde visuele technologieën' (Toneelhuis, 2008, p. 22).

In de subsidieaanvraag voor de periode 2013-2016 werd IBBT nog steeds opgevoerd. Toneelhuis verstrekte een opdracht aan het instituut om onderzoek te doen naar de mogelijkheid van opvouwbare/afbreekbare objecten. Vooral het uitwerken van werk van kunstenaar Daniel Rozin rond het materialiseren van spiegels en glanzende bollen, zou nieuwe beeldmogelijkheden kunnen leveren in Cassiers' regies. Het EDM-project is

\footnotetext{
${ }^{77}$ Open innovatiesystematiek: Hierbij gaan steeds meer bedrijven er van uit dat zij niet meer de geprivilegieerde leveranciers van kennis en ideeën zijn, maar daarvoor een beroep doen op externe instellingen, individuen of groepen (Toneelhuis, 2008, p. 22).
} 
in de Aanvraag Toneelhuis 2013-2016 geschrapt. Daarvoor in de plaats werd voor de periode 2013-2016 een onderzoeksproject ontworpen voor Benjamin Verdonck en de burgerlijk ingenieur Milieukunde Peter Tom Jones van de KU Leuven. Jones is daar een van de pioniers van Terra Reversa, de denktank voor ecologische economie. Het werk van Jones en zijn collega's bood inspiratie voor Verdoncks Handvest voor een actieve medewerking van de podiumkunsten aan een transitie naar rechtvaardige duurzaamheid. Verdonck heeft als kunstenaar niet zozeer een wetenschappelijke rol in het onderzoeksproject maar: 'Het is veeleer het "out of the box" denken als grondhouding van de kunstenaar die een onderzoeker als Jones kan prikkelen' (Toneelhuis, 2011, p. 22).

Het doelbewust opzoeken van deze voor theatermakers niet vanzelfsprekende contacten duidt op een veranderend artistiek klimaat en komen we anno 2015 op meerdere plaatsen in het podiumkunstenlandschap tegen. Cassiers en de zijnen zoeken naast de interdisciplinaire artistieke diversiteit tevens de grenzen op van wat hedendaagse technologie zou kunnen bieden als toepasbaar theatraal instrumentarium en wat podiumkunstenaars op hun beurt zouden kunnen leveren voor het lopende ecologische discours. Het gaat daarbij niet in de eerste plaats om de nieuwste gadgets om het spektakel in het theater te vergroten of om wetenschappelijke bijdragen. Het gaat om technologie die onze omgang met technologie kan problematiseren, technologie om traagheid te kunnen hanteren, om live gebruik te maken van cinematografische close ups door middel van streaming video, om te schilderen met licht en geluid bij de vormgeving van literaire verhalen, van installaties en choreografieën. Het gaat om het in artistieke termen actief meedenken over problemen waar de samenleving zich voor gesteld ziet.

Ook internationaal investeert Toneelhuis Antwerpen in contacten, waarbij niet alleen voorstellingen worden gespeeld op de gebruikelijke publieke theaterpodia. Het gezelschap wordt regelmatig uitgenodigd voor voorstellingen op wetenschappelijke congressen of festivals of om gesprekspartner te zijn in het theaterwetenschappelijke of kunsttheoretische discours, rond thema's als de relatie tussen kunst en wetenschap, de rol van technologie in de kunsten, de relatie tussen performers en publiek, de beweging van woord naar beeld in wat Lehmann visuele dramaturgie noemt of de relatie tussen theatraliteit, performativiteit en narrativiteit. Naast internationale aandacht voor het practice as research aspect van het werk van Toneelhuis wordt de laatste jaren door Cassiers en enkele van zijn Nederlandse en Vlaamse collega's ingezet op een internationale samenwerking tussen gezelschappen, podia en festivals op een manier die doet denken aan het samenbrengen van artistieke diversiteit in het gezelschap Toneelhuis Antwerpen. Guy Cassiers, Johan Simons en Ivo van Hove hebben stappen gezet om een samenwerkingsverband te gaan vormgeven tussen Toneelhuis Antwerpen, Toneelgroep Amsterdam, Thalia Theater in Hamburg, Ro 
Theater te Rotterdam, Münchener Kammerspiele en het festival Ruhrtriënnale. Het netwerk zou in het komende decennium vorm moeten krijgen door coproducties, gastregies over en weer en uitruil van acteurs, actrices, performers en technici. De intentie is te komen tot een gezamenlijk hoger niveau van intermediaal, intercultureel en internationaal theater- en performanceonderzoek.

\section{Strategische inzet van gebouw en mensen}

In de personele bezetting van Toneelhuis Antwerpen springt niet alleen het aantal technici in het oog, een ander opvallend verschil ten opzichte van bijvoorbeeld een Nederlands gesubsidieerd gezelschap is de categorie onthaal schouwburg. Het gaat om negen personeelsleden die de bezoekers van de Bourla schouwburg welkom heten. Meer financiële impact nog dan het personele aspect heeft het feit dat onderhoud en beheer van het historische rijksmonument volledig op de begroting van Toneelhuis drukt. $^{78}$ Dit was al zo in de tijd voordat Cassiers aantrad. Hoe het beheer van het gebouw specifiek veranderd is bij zijn aantreden, is niet in detail weer te geven. Wel is duidelijk dat het gebouw optimaal en bij vlagen zeer onorthodox wordt gebruikt door de zeven theatermakers.

Exemplarisch voor de onorthodoxe inzet van het gebouw, van mensen en van middelen was het project Een geschiedenis van de wereld in $101 / 2$ hoofdstuk. Met deze groots gemonteerde voorstelling, waarbij het gehele gebouw van de schouwburg gebruikt werd, presenteerde Toneelhuis in april 2007 in één voorstelling al zijn theatermakers aan de stad Antwerpen als leden van de nieuwe veelkoppige artistieke staf van het stadsgezelschap. De voorstelling was gebaseerd op de gelijknamige roman van Julian Barnes (Barnes, 1991). Deze roman uit 1989 bevat losse verhalen en een slotbeschouwing. De verhalen zijn afzonderlijk te lezen maar kennen tevens een rode draad rond de mythe van de ark van Noach. Ze gaan over uiteenlopende zaken, zoals een houtworm die als verstekeling meevaart met de ark, de totstandkoming van het schilderij Het vlot van de Medusa (Géricault, 1818), een tocht naar de berg Ararat, een kaping van een luxe jacht; alles bij elkaar tien verhalen over geïsoleerdheid, ontberingen en overleven. Toneelhuis gebruikte de samengestelde roman als metafoor voor de nieuwe constructie van het gezelschap: verschillende makers met een verbindende rode draad. Cassiers heeft bij de aftrap van het project hoofdstukken uit

\footnotetext{
${ }^{78}$ De begrotingsindeling van Toneelhuis zag er anno 2009 als volgt uit: Creatie en spreiding (maken en presenteren van producties): $\quad 53,6 \%$ Publiekswerving en werking (marketing en informatieverschaffing): $\quad 10,2 \%$ $\begin{array}{ll}\text { Exploitatie Bourla schouwburg } & 22,4 \%\end{array}$ Omkadering (overhead) $\quad 13,8 \%$.
} (Toneelhuis, 2008, p. 29) 
het boek aan de makers voorgelegd. Na discussie heen en weer ging iedereen aan het werk om ergens in het gebouw beslag te leggen op een ruimte en om op basis van een van de hoofdstukken een voorstelling, installatie of performance te maken.

Kostuumontwerpster Valentine Kempynck daarover:

'Het gebouw, de tekst en de makers, dat zijn de drie onderdelen van de voorstelling. De verhoudingen en de relaties daartussen moeten vormgegeven worden. (...) Het project is een kennismaking van iedereen met iedereen in Toneelhuis: artiesten, technische ploeg en ander personeel. ledereen participeert op een of andere manier' (Jans, 2007a).

Met deze openingsgebeurtenis probeerde Toneelhuis duidelijk te maken dat een gebouw als de Bourla schouwburg een open gemeenschapsgebouw kon zijn en niet per definitie alleen maar een bolwerk voor theateringewijden. Door zich op de mogelijke publieksfuncties van het gebouw te richten poogden de theatermakers verantwoordelijkheid te nemen voor een substantieel deel van de openbare ruimte en van het publieke debat in de stad Antwerpen.

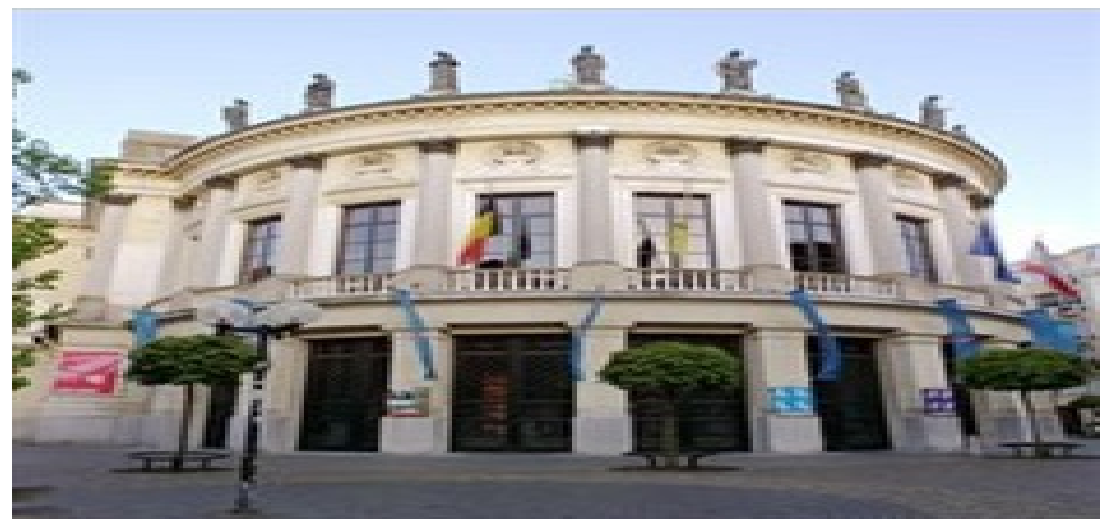

Fig. 6 De Bourlaschouwburg werd in 1827 ontworpen door P. Bourla.

Dramaturgisch, organisatorisch, productioneel en wat de intentionele publiekswerking betreft, lijkt de Toneelhuisconstructie het actuele hectische stadsleven te weerspiegelen. Daarbij past ook dat Toneelhuis in de Bourla culturele programma's organiseert samen met geestverwante collega- theatermakers, podia en gezelschappen in de stad Antwerpen. Sinds 2008 vindt onder auspiciën van Toneelhuis jaarlijks het stadsfestival Antwerpse Kleppers plaats. In de maand februari zijn hierbij uitwisselingen, samenwerking en confrontaties tussen verschillende kunstenaars, podiumkunstorganisaties en hun publiek te beleven. Dit initiatief kenmerkt de aanpak 
van het Toneelhuis, men wenst expliciet te investeren in het uitlichten van de sociale en culturele biodiversiteit van de stad Antwerpen, juist in een cultureel iconisch gebouw als de Bourla schouwburg. Intentioneel worden hier interculturele ontmoetingen uitgelokt en gestimuleerd; de optredende gasten uit de eigen stad belichamen als het ware het Antwerpse publiek voor Toneelhuis als organisatie.

Om de samenwerking van alle betrokkenen bij het werkproces van het Toneelhuis in goede banen te leiden opereert in het hart van de theaterorganisatie An-Marie Lambrechts. Na werkzaam te zijn geweest als universitair docent bij de vakgroep Theaterwetenschap van de Universiteit van Leuven ${ }^{79}$, werd Lambrechts vooral gevormd door haar ervaringen als dramaturg van Kunstenfestival des Arts in Brussel, het directeurschap van het kunstencentrum STUK in Leuven en als producent van educatieve video's bij het Vlaams Theater Instituut. Cassiers vroeg haar bij zijn aantreden om als artistiek coördinator mee vorm te komen geven aan zijn ambities. Ze gaf in ons gesprek onmiddellijk aan dat ze het moeilijk vond om haar functie te omschrijven.

AML: Het is niet echt een functie, hè.

$\mathrm{HH}$ : Artistiek coördinator staat er?

AML: Ja, we zijn er eigenlijk na twee en een half jaar nog niet uit of het een echte baan is.

$\mathrm{HH}$ : Maar het is wel een centrale kruispuntfunctie.

AML: Eigenlijk heeft het te maken met hoe het ding in elkaar zit. Toen het huis hier werkte, hiervoor, met een hoofdregisseur, misschien ook nog wel tweede en kleinere projecten en je komt nu naar Guy. Zijn inzet was om aan al die zeven makers een context te bieden die aansloot op hun manier van theaterwerken. Dat wat je doet en hoe je 't doet, dat die twee op elkaar aansluiten. Het idee van wat je doet is gelijk aan hoe je 't doet, dat komt van de kleine huizen, de kleine kunstencentra, de kleine gezelschappen, daar is het hoe is het wat, want die twee dicteren elkaar.

$\mathrm{HH}$ : Dat is meer jouw STUK-ervaring?

AML: Ja, dus de bedoeling was eigenlijk om te proberen, en nu zeg ik echt proberen, hè, om die nauwere aansluiting bij hoe je dingen doet niet alleen te faciliteren, maar dat je ook bedenkt wat je wilt bereiken, dat je dat eens zou moeten proberen te installeren in dat grote huis. Dus dat is een andere manier van werken, namelijk dat zijn zeven manieren van werken. Nu is het helder dat het vanaf het begin een onmogelijke opdracht was. Je kunt onmogelijk een huis dat op een bepaalde manier gestructureerd is, plots op een totaal andere manier gaan laten functioneren.

\footnotetext{
${ }^{79}$ Samen met Geert Opsomer en Erwin Jans heeft Lambrechts in de tweede helft van de jaren tachtig aan de basis gestaan van de hervorming van deze vakgroep.
} 
Dus wat er ontstaat is permanente onderhandeling eigenlijk tussen de bestaande structuur en de nieuwe structuur.

$\mathrm{HH}$ : Steeds onderhandelen...

AML: Ja, in die onderhandelingen speel ik mijn rol. Dus is dat een job? Eigenlijk is dat geen job. ${ }^{80}$

In het vlakkevloercircuit bestaat er volgens Lambrechts een organisch verband tussen het wat en het hoe bij de totstandkoming van voorstellingen. Deze simpele redenering was in 2006 een van de artistieke uitgangspunten voor het nieuwe gezelschap. De zeven makers dienden zich in hun ambities niet alleen af te vragen wat ze gingen maken en ensceneren, maar ook hoe ze dat gingen doen. leder van de kunstenaars werd naast zijn artistieke planning ook geacht na te denken over zijn publiek, zijn podia, zijn publieksbenadering, zijn publiciteit en zijn technologische middelen. Dat alles bovendien in samenspraak met de collega's binnen het gezelschap. Dus in plaats van één dwingende artistieke visie met hier en daar incidenteel een gastoptreden, werd er uitgegaan van de inbreng vanuit zeven artistieke visies met zeven verschillende versies van wat en hoe en bovendien onder de koepel van een groot theaterhuis. Van begin af aan was duidelijk dat daar een zeer complexe planning en organisatie bij zou gaan horen.

AML: Ik denk dat 't heel belangrijk is om telkens te vertrekken vanuit het artistieke project. Als je ziet wat iemand als Benjamin (Verdonck $\mathrm{HH}$ ) wil doen, hoe dat hij dat tot stand brengt, is voor hem van wezenlijk belang, die twee zijn niet loskoppelbaar. Ik kan bijna nooit puur instrumenteel werken. Je moet dat eigenlijk vanuit dezelfde filosofie kunnen doen, maar tussen de vaste structuur en die steeds nieuwe insteken. Dus het is onmogelijk, natuurlijk, om in een structuur van laten we zeggen tachtig mensen een permanente flux te creëren.

$\mathrm{HH}$ : Dat kan natuurlijk niet, nee.

AML: Je moet dus ergens een compromis vinden tussen de vastigheid van een bedrijf en de flexibiliteit die hier aan de orde is.

$\mathrm{HH}$ : Van die zeven artistieke processen?

AML: Ja. Al heel wat van die makers hebben zelf op hun beurt verbindingsofficieren, dat zijn vaak deeltijdcoördinatoren die eigenlijk ook al een soort van sluisje spelen en die mijn eerste aanspreekpunt zijn. In die onderhandelingen speel ik zo goed en zo kwaad mogelijk een rol. Dat betekent dat je gaat onderhandelen op alle niveaus, productie, techniek, communicatie, want al die dingen hangen aan elkaar.

\footnotetext{
${ }^{80}$ Uit de transcriptie van het interview met An-Marie Lambrechts op 13 juni 2008 te Antwerpen [digitaal audio bestand] (timer 4.00) (transcriptie H.Havens).
} 
En altijd opnieuw is het idee dat je wat je doet en hoe je het doet, met elkaar in verband moet brengen.

$\mathrm{HH}$ : Dat is een opgave.

AML: Dat is eigenlijk de reden dat ik geen departement onder me heb. Ik ben solo, een aparte pion in het geheel die als het goed gaat er niet aan te pas hoeft te komen en als het fout gaat, probeer ik te zien van, oké, waar willen we naar toe, hoe kunnen we dat doen, waar kunnen we een oplossing vinden. En de beperking is namelijk ook tussen de vastigheid en de flux die je hier nodig hebt, je kan nooit helemaal tot daar geraken. En dat is ook de reden dat een aantal mensen na een aantal jaren zegt, dit voldoet mij toch niet en een aantal andere mensen zegt, ja, ik vind daar wel mijn weg in, want ik bedien mij van dit en ik ga vooruit. Je ziet bijvoorbeeld heel goed dat sommige mensen een internationale vlucht hebben gekregen in hun werk omdat de gestructureerdheid waarmee internationaal werken hier wordt aangepakt, hier rendeert voor hen. Dus je ziet dat zij van die schaalvergroting absoluut rendement hebben, maar de downside...

HH: De moeilijke kant...

AML:...de moeilijke kant blijft om de directheid van een kleine groep van mensen rondom je, die eigenlijk allen in dezelfde richting stuwen, de samenhang daarvan blijft moeilijk te creëren binnen deze combinatie. Dus dat is de frictie die echt ingeschreven is en altijd ingeschreven zal blijven in dit model. ${ }^{81}$

\section{Doorstroming}

De innovatieve organisatiestructuur van het gezelschap past niet iedereen even goed. Men gaat bij het Toneelhuis in dat verband de kritische zelfreflectie niet uit de weg, zoals tussen de regels uit het aanvraagdossier voor 2010-2013 te lezen is:

'Met alle bovenstaande doelen voor ogen heeft Toneelhuis in de afgelopen twee jaren aan een nieuwe ploeg gebouwd. Hierbij mag geenszins uit het oog verloren worden dat de omschakeling die hierbij van werknemers gevraagd is, meer dan aanzienlijk is: er is niet alleen een nieuwe organisatiestructuur (rondom 7 artiesten i.p.v. 1 artiest), er wordt ook op andere vlakken expertise gevraagd (bijv. op video- en klanktechnologisch vlak), en dat binnen verschillende disciplines (theater, dans, muziektheater, performance), in verschillende 'formats' (locatiewerk naast het werk in de Bourla), in verschillende ritmes en ordes van grootte, in verschillende tourneeschema's (internationaal/regionaal), enz. Net door deze alternatieve combinatie van eisen verkozen sommige personeelsleden

\footnotetext{
${ }^{81}$ Uit de transcriptie van het interview met An-Marie Lambrechts op 13 juni 2008 te Antwerpen [digitaal audio bestand] (timer 6.32) (transcriptie H.Havens).
} 
het huis te verlaten en hebben anderen zich binnen het huis geheroriënteerd; nog anderen zijn nieuw en van buiten af aangetrokken. Zo is nu een mix ontstaan van mensen die al langer voor Toneelhuis werken en nieuwe medewerkers. Toch blijft een verhoogde aandacht voor onderlinge communicatie over al deze nieuwe terreinen en vragen van levensbelang voor de organisatie' (Toneelhuis, 2008, p. 31).

Een van de meest ingewikkelde en publiciteitsgevoelige operaties bij de start was om de contracten van de toneelspelers van het oude Toneelhuis niet meer te verlengen. Het kostte de nodige moeite om betrokkenen ervan te overtuigen dat dit absoluut noodzakelijk was om te komen tot een volkomen nieuw theaterbedrijf. Toneelspelers en performers werden niet meer in vaste dienst genomen, maar alleen nog maar aangenomen op tijdelijke contractbasis voor hun werk ten dienste van een van de zeven theatermakers. Overigens hebben er nog nooit in de geschiedenis van het gezelschap zoveel performers, dansers en acteurs onder contract gestaan als in de eerste jaren van de vernieuwde Toneelhuisconstructie.

Vanaf het begin is met iedere individuele theatermaker in de artistieke staf intensief onderhandeld over artistieke ambities en plannen. De meesten staan als maker onder vast contract bij Toneelhuis voor een deel van hun tijd. Sommigen hebben een aanstelling voor 50 procent, anderen voor 80 , weer anderen voor 60 . Dat geeft eenieder de mogelijkheid om ook nog ander artistiek werk te verrichten dan alleen voor Toneelhuis. Op een vergelijkbare manier is vanaf het begin open gesproken over beschikbare productiebudgetten. De makers hebben verschillende artistieke ambities en maken dientengevolge ook aanspraak op verschillende budgetten om die te verwezenlijken. Door onderdeel te zijn van het artistieke gezicht van het Toneelhuis committeren de makers zich aan het gezelschap, aan de Bourla schouwburg en zijn publieke werking en daarmee aan de stad Antwerpen. Mochten de werkzaamheden buiten Toneelhuis een onevenredig groot artistiek en logistiek beroep doen op een van de makers, dan wordt opnieuw gesproken over de aard en intensiteit van de artistieke verbintenis.

Vanaf de start van Toneelhuis was er sprake van een ambitie om kunstenaars door te laten stromen. De contacten met de zes kunstenaars buiten Cassiers werden bezien vanuit een perspectief van tijdelijkheid. In principe zou het gaan om verbintenissen lang genoeg voor een herkenbaar verband, kort genoeg om nog door te kunnen groeien en plaats te maken voor anderen in nieuwe constructies, gebaseerd op hetzelfde principe: zich verhouden tot de andere makers, tot de grote zaal van de Bourla schouwburg en daarmee tot de diversiteit van Antwerpen en van de internationale kunstenscene. Het is daarbij tevens steeds uitgangspunt geweest dat kunstenaars die na verloop van tijd verder trekken een bepaalde artistieke band 
moeten kunnen onderhouden met Toneelhuis en daarmee met Antwerpen. In het ene geval zal dat makkelijker zijn dan in het andere, maar alle partijen streven naar zo'n verband van geassocieerden.

In dit collectieve leerproces zijn alle makers al na een paar jaar opgeschoven naar andere posities in het landschap dan die ze hadden bij de start van het gezelschap in 2006. Aan het eind van het tweede seizoen vond de eerste professionele doorstroming plaats. Lotte van den Berg ging het toenmalige nieuwe gezelschap Omsk leiden in Dordrecht en tevens haar filmambities vormgeven. Sidi Larbi Charkoui maakte zijn banden met Toneelhuis losser om plannen met een eigen dansgezelschap door te ontwikkelen en om zijn internationale carrière ruimte te geven. Wayn Traub ging zich voor een groot deel wijden aan de muziek. Het onderzoekswerk van Peter Missotten verschoof in de loop van 2008 naar de arena van de grote zaal van de Bourla schouwburg en naar diverse operapodia in Europa. Aan het eind van seizoen 2009/2010 heeft ook Missotten Toneelhuis verlaten; hij is sindsdien werkzaam als onafhankelijk regisseur, scenograaf, videokunstenaar en is als docent en onderzoeker verbonden aan de performanceopleiding van de Toneelacademie Maastricht. ${ }^{82}$ Vanaf 2006 zijn de Nederlandse actrice en regisseur Abke Haring en de Vlaamse theaterauteur, essayist en dichter Bart Meuleman deel gaan uitmaken van de artistieke staf. Per seizoen 2012-2013 kwamen daar het complete Antwerpse gezelschap F.C. Bergman, de Irakees-Vlaamse acteur en regisseur Mokhallad Rasem en de Vlaamse acteurs en actrices Tom de Wispelaere, Johan van Assche, Kevin Janssens, Katelijne Damen en Marc van Eeghem bij.

De banden met de zogeheten doorstromers blijven waar mogelijk in stand. Ze blijven graaggeziene gasten in Antwerpen, ze worden vanaf hun vertrek beschouwd als een soort 'bevriende naties'. ${ }^{83}$ Zij maken plaats voor andere theatermakers, die in de ogen van Cassiers en de zijnen artistiek toe zijn aan het grote podium van Toneelhuis in Antwerpen en aan vergelijkbare podia in binnen- en buitenland. Dit is een wat specifiekere variant van het begeleidingsprogramma voor jonge theatermakers dat het afgelopen decennium in Nederland veel besproken werd. Daarbij werden jonge, beginnende theatermakers naar een zelfstandige artistieke loopbaan begeleid door de grote stadsgezelschappen. Men gaat daarbij in Nederland over het algemeen uit van één artistieke visie per gezelschap en meestal niet van een theatervisie van het verschil, zoals in het experiment van Cassiers en de zijnen.

\footnotetext{
${ }^{82}$ Het werk van Missotten als scenograaf ging de wereld rond met de voorstellingen van Cassiers, als filmer voor bijvoorbeeld William Forsythe en het Ballet Frankfurt en als docent performance en scenografie.

${ }^{83}$ Het aanvraagdossier voor 2010-2013 werd officieel mede ondertekend door Josse de Pauw en Lotte van den Berg als 'verwante makers', en door Sidi Larbi Cherkaoui als 'in residentie'. Ondanks hun stappen in een zelfstandige artistieke praktijk, blijkt hieruit hun blijvende verbondenheid met de 'missie' van Toneelhuis Antwerpen (Toneelhuis, 2008).
} 
Na de eerste jaren heeft de nieuwe gezelschapsconstructie ervoor gezorgd dat de carrière van de ene theatermaker een hoge internationale vlucht heeft genomen, voor de andere is de schaalvergroting een ware leerschool geweest en voor weer anderen heeft het in deze combinatie minder opgeleverd dan wat aanvankelijk verwacht werd. Een moeilijkheid blijft om met de directheid die binnen een kleine groep mensen kan bestaan, op een grotere schaal vanuit het verschil dezelfde richting in te blijven denken. Alle zeven theatermakers hebben in de eerste twee jaar de frictiegebieden rond betrokkenheid en professionaliteit gevoeld. Die fricties heeft men bij Toneelhuis als een noodzakelijk kwaad leren accepteren. Zo zijn rond de individuele theatermakers eigen sferen gegroeid waarbinnen bepaalde spelers, dansers, performers en technici zich groepeerden. Men was zich er daarbij van bewust dat de doorstromingsprocessen problemen op zouden kunnen leveren omdat bijvoorbeeld vormgevers en technici doorstromende theatermakers zouden kunnen volgen vanwege een artistieke verwantschap. Het tegenovergestelde was ook denkbaar: dat zij juist verbonden wilden blijven met het Toneelhuis vanwege de gezelschapsconstructie als huis van het verschil.

\subsection{Toneelhuis Antwerpen en het postdramatisch discours}

We zien dat in Antwerpen na de herstart van Toneelhuis in 2006 door een radicale breuk met het idee van het klassieke toneelspelersensemble een nieuw soort gezelschap is ontstaan rond een kern van theatermakers. Het aanvankelijke theatergezelschap veranderde door die nieuwe aanpak in een anders georganiseerd theaterbedrijf dat in beginsel uitgaat van ander bronnenmateriaal en een andere theateresthetiek dan men van reguliere theatergezelschappen gewend is. In deze paragraaf zal ik achtereenvolgens de gevolgen van deze transformatie analyseren voor het repertoire, voor de organisatie van het gezelschap en voor de positie van het gezelschap in het theaterlandschap.

\section{Repertoire}

Er zijn bij Toneelhuis nauwelijks nog toneelmatige repertoirezekerheden gebaseerd op een nationale of westerse toneelcanon; vanaf de start zag het nieuwe gezelschap af van het a priori spelen van regulier toneelrepertoire. ${ }^{84}$ Romans vormden de afgelopen jaren veelal de basis, maar er is ook theaterwerk gemaakt helemaal of deels

\footnotetext{
${ }^{84}$ Vanaf 2012 worden samenwerkingsambities met grote Europese gezelschappen vormgegeven waarbij er weer wel sprake is van het spelen van canoniek toneelrepertoire, maar nu als een van de repertoiresegmenten, en niet als hoofdopdracht. In het voorjaar van 2014 ging Hamlet vs Hamlet in première, een samenwerking met TGA, met Toneelhuis performer Abke Haring in de hoofdrol.
} 
geïnspireerd op specifiek filmrepertoire, op het werk van beeldende kunstenaars, er is dans geproduceerd op basis van niet-westerse culturen en soundscapes waren in veel gevallen belangrijker dan de tekst. Kortom: in de periode 2006 - 2013 is nauwelijks regulier gebruikgemaakt van toneelteksten. Daarmee is veel van het werk van de theatermakers van Toneelhuis Antwerpen gekleurd door de onzekerheid over de werking ervan in het theater. In veel gevallen onderging het publiek samen met het uitvoerende gezelschap nog niet eerder uitgevoerd theaterrepertoire.

Het werk van de theatermakers van Toneelhuis wordt in al deze diversiteit gekenmerkt door de door Lehmann geïnventariseerde postdramatische theatertekens: de dramaturgie van de nevenschikking, het loslaten van dwingende theatrale samenhang, het loslaten van de toneeltekst als blauwdruk voor theatervoorstellingen, het gebruik van een droombeeldtextuur met als kenmerk het wegvallen van hiërarchie tussen beeld, beweging en woord, de basis voor een visuele dramaturgie (Lehmann, 1999, p. 146). De manier waarop Lehmann postdramatische traagheid beschrijft herkennen we in Cassiers' ensceneringen van specifiek trage literaire romans als die van Musil, Bernlef, Brouwers, Claus, en Lowry. In Toneelhuisvoorstellingen zijn postdramatische technieken als verdubbeling, fragmentatie, herhaling, de inzet van muzikale, cinematografische en dansante constructieprincipes te traceren. Hiermee is de canonieke toneeltekst duidelijk niet meer dominant, niet meer hoger in hiërarchie dan de andere theatermiddelen (vormgeving, beeldprojectie, soundscapes, muziek, dans, kostumering). Het gaat daarbij ook niet om het vervangen van het ene medium door het andere, het beeld neemt de hoofdrol niet over van de tekst, er ontstaat in het samengaan iets anders.

Het geprojecteerde beeld in het werk van Cassiers is geen pure cinema en tevens is de voorstelling door de geprojecteerde beelden geen puur theater meer want er ontstaat door de mix van media ook een 'besmetting'. De roman-ensceneringen zijn niet meer puur literatuur, het acteren krijgt een extra dimensie door de live streaming video sequenties, vormgeving wordt belichting en andersom, en het geprojecteerde beeld wordt staged cinema. In voorstellingen van Cassiers zijn videobeeldcomposities en soundscapes voor een nevenschikkende dramaturgie minstens zo belangrijk als de tekst; in het werk van Benjamin Verdonck is vaker sprake van performatieve presentatie en van artistiek onderzoek dan van toneelmatige dramatische representatie; Missottens voorstellingen zijn vaak meer installaties om te ondergaan, te ervaren, dan theatervoorstellingen om naar te kijken en luisteren; Sidi Larbi Cherkaouis choreografieën bouwen meer voort op zijn internationaal georiënteerde onderzoek naar interculturele esthetica dan op de academische danstraditie. Over dit repertoire kunnen we met een term van Lehmann spreken als zwischen den Künsten (Lehmann, 1999, p. 201). 
Technologie is door de manier waarop Cassiers haar tot theatertaal heeft gemaakt veel meer geworden dan een aan de voorstelling dienstbaar theatermiddel. De inzet van audio- en beeldtechnologie kenmerkt het intermediale karakter van het Toneelhuisrepertoire. Door intermedialiteit verhevigt de werking van de postdramatische theatrale tekens (Kattenbelt, 2006, 2010). Het levert in de confrontatie tussen performers en toeschouwers een intensivering van de ervaring op; Cassiers heeft het in dit verband over 'het weer openzetten van de zintuigen' (G. Cassiers, 7 februari 2008). Die intensivering houdt meer verband met het presentatiekarakter van performances dan met het representatieve dat eigen is aan voorstellingen op basis van literair dramatische theaterteksten.

De verhevigde werking van de postdramatische theatertekens levert in de relatie met het theaterpubliek niet alleen bewondering en succes op, maar soms ook frictie en weerbarstigheid, zoals het voorbeeld van Winterverblijf van Van den Berg liet zien. Het gemiddelde theaterpubliek heeft andere verwachtingen van een avond theater dan wat Van den Berg presenteerde. Het artistieke team van Toneelhuis neemt daarbij bewust risico's door de theatermakers zich te laten verhouden tot de grote zaal. De programmering van de grote zaal en anderszins het gebruik van de Bourla schouwburg zijn in dit verband ook op te vatten als horend bij het repertoire van Toneelhuis. Cassiers behoort tot de generatie kunstenaars die zich in de loop van de jaren zeventig en tachtig juist erg afzetten tegen het theater voor de grote zaal, dat toen werd beschouwd als een verouderde, weinig relevante vorm van theater (Lehmann, 1999, p. 214). Eind jaren tachtig en begin jaren negentig ontstond in de Nederlands-Vlaamse theaterwereld echter een hernieuwde interesse voor de grote zaal, ook bij Cassiers. Volgens hem was dat niet zozeer vanwege een hernieuwde belangstelling voor het daarop toegesneden regulier repertoire, maar vooral door de mogelijkheden die de grote zaal bood om zich op een geëngageerde manier opnieuw te verhouden tot een groot publiek, tot de gemeenschap van een stad.

Theaterpubliek voor de grote zaal komt met bepaalde verwachtingen. Volgens de Duitse literatuurwetenschapper Hans-Robert Jauss, die in zijn Towards an Aesthetic of Reception (1982) de receptie van poëtisch werk analyseert, schuilt er een patroon in het langzaam veranderen van de receptie van complexe kunst.

"The new text evokes for the reader (listener) the horizon of expectations and 'rules of the game' familiar to him from earlier texts, which as such can be varied, extended, corrected, but also transformed, crossed out, or simply reproduced. Variation, extension, and correction determine the latitude of a generic structure; a break with the convention on the one hand and mere reproduction on the other determines its boundaries" (Jauss, 1982, p. 88). 
Jauss onderscheidt twee soorten verwachtingshorizonnen: die van het kunstwerk en die van het publiek. De afstand tussen die twee noemt hij de esthetische afstand. Voor voorstellingen zoals Winterverblijf gold dat de esthetische afstand tussen de verwachtingshorizon van de voorstelling en die van het publiek te groot was. Een gezelschap als Toneelhuis verlegt in zijn zoektocht naar een nieuwe theatertaal steeds de esthetische afstanden tussen publiek en theaterkunstenaars. Na eerdere gewenning aan Cassiers nieuwe hightech theatertaal in voorstellingen van het Ro Theater als de Wespenfabriek (2000), The Woman Who walked into Doors (2001), de Proustcyclus (2003-2005) en Bezonken rood (2004) heeft deze haar weg gevonden naar Europese podia en verder. Toneelhuis gaat uit van vergelijkbare processen met het werk in de grote zaal van de andere theatermakers van het gezelschap. Het is de bedoeling dat door stapsgewijze toenaderingen de esthetische afstand tussen verwachtingshorizonnen afneemt.

Het duurt meestal even voordat beoogde veranderingen worden geaccepteerd als niet-betekenisdragende breuken (Deleuze \& Guattari, 2004, p.29) met de gangbare theatercultuur. Cassiers benoemt in een interview uit 2006 drie strategieën om het publiek in dit soort processen te benaderen. In de eerste plaats kan de kunstenaar zich bedienen van een technologisch instrumentarium en alle soorten van media, zoals die ook manifest aanwezig zijn in ons dagelijks leven. Ten tweede kan de kunstenaar de verrassing inzetten, hij kan mentale filters ontregelen. En ten derde noemt hij de kunstenaar als mediacriticus. ${ }^{85}$ Anders omgaan met de veelheid van informatie lijkt centraal te staan, bijvoorbeeld door chaos te accepteren. Lehmann verwijst in dit verband naar Marianne van Kerkhoven die in haar essay Die Last der Zeiten nieuwe theatertaal verbindt met de chaostheorie (Lehmann, 1999, p. 141). De exponenten van deze theorie gaan ervan uit dat de werkelijkheid meer uit instabiele systemen bestaat dan uit gesloten stabiele kringlopen en dat het niet zo vreemd gevonden hoeft te worden dat de kunsten daar met niet-eenduidigheid, met polivalentie en simultaneïteit op kunnen reageren. Intentioneel is dat in ieder geval waar te nemen in de dramaturgie van het door Toneelhuis vormgegeven repertoire en in de organisatie van het gezelschap.

\section{Gezelschap}

Om zijn diverse, door technologie gekenmerkte, intermediale repertoire te kunnen brengen is Toneelhuis Antwerpen getransformeerd in een ander soort gezelschap dan een regulier toneelgezelschap. De koers van het herijkte gezelschap is de afgelopen jaren gekenmerkt geweest door een aantal pregnante veranderingen: het niet uitgaan

\footnotetext{
${ }^{85}$ Cassiers geinterviewd bij de start van de nieuwe theateronderneming in 'Theatermaken: een permanent proces van herschikken' (Jans, 2006c).
} 
van één artistieke theateresthetische richtlijn maar van zeven of meer mogelijke artistieke invalshoeken; het doorontwikkelen van de artistieke emancipatie van een grote groep theatertechnici tot op het niveau van de artistieke staf; het plaats inruimen voor een formeel onderzoeksaspect in de werking van het gezelschap; het hanteren van een doorstromingsbeleid waardoor de werking van het gezelschap in de loop der tijd meerdere professionals 'besmette' en voormalige Toneelhuiskunstenaars sinds hun verbintenis als artistieke satellietstaten van het Antwerpse gezelschapsconcept opereren.

Toneelhuis Antwerpen is door dit alles in de strikte zin des woords geen toneelgezelschap meer te noemen en misschien zelfs wel geen theater-gezelschap meer. Intermedialiteit en de onthiërarchisering van theatermiddelen, die waarneembaar zijn in de repertoiretransformaties van het gezelschap, hebben even onlosmakelijk als onvermijdelijk een parallel opgeleverd in de samenstelling en organisatie van het gezelschap. Het aanvankelijke theatergezelschap is een hybride theater-, media- en performancebedrijf aan het worden, dat zichzelf als hybride kunstbedrijf steeds opnieuw uitvindt. Het wijkt als groot gevestigd theatergezelschap in zijn structuur nu al zo radicaal af, dat het daarmee wat Latour traceerbaar noemt (Latour, 2005, pp. 3031 ) is; het gezelschap is zichtbaar op basis van een breuk met het verleden. Dit opnieuw uitvinden doet het bedrijf zowel op het niveau van de artistieke productie (repertoire) als met de structurele vormgeving van het instituut Toneelhuis Antwerpen (organisatie en bedrijfsvoering). Onthiërarchisering betekent daarbij niet alleen een herschikking van theatrale middelen in voorstellingen maar ook structureel veranderende verhoudingen binnen een relatief nieuwe hybride verzameling van artistiek samenwerkende theatermakers, dramaturgen, technici, videokunstenaars, acteurs, performers, dansers, kostuumontwerpers, cateraars en anderen, inclusief de soms weerbarstige groepsdynamische processen. Het is niet voor niets dat voor het in goede banen leiden van deze processen een functie als artistiek coördinator in het leven werd geroepen.

Wat nieuw repertoire en nieuwe werkwijzen betreft is Toneelhuis niet het enige theaterkunstbedrijf dat andere brongebieden betreedt, het is exemplarisch voor het ensceneren van materiaal anders dan het strikt toneelmatige. Nieuwe soorten theaterprofessionals dienen zich bij meerdere gezelschappen aan en ook andere grootschalige gesubsidieerde Nederlandstalige theatergezelschappen brengen van het canonieke afwijkende theatervoorstellingen en gaan net als Toneelhuis Antwerpen steeds meer internationaal opereren: regisseur Johan Simons bracht met NTGent, tot hij per 1 januari 2010 vertrok naar de Münchener Kammerspiele, onder andere theater op basis van de romans van Michel Houellebecq en op basis van de films van Krzysztof Kieślowski; van regisseur Ivo Van Hove is bekend dat hij veel voorstellingen maakt op basis van speelfilms, met name van John Cassavetes en van Michelangelo Antonioni. In 
de peergroup van internationaal opererende grootschalige theatergezelschappen is deze werkwijze min of meer gemeengoed geworden, al heeft elk gezelschap wel een bij een specifieke theatermaker behorend specialisme. Wat Toneelhuis in deze context uniek maakt, is het structureel doorgevoerde organisatiemodel van het gezelschap op basis van artistieke diversiteit: een flexibel, intentioneel tijdelijk ensemble van makers in plaats van een ensemble van acteurs en actrices.

Door het diverse repertoire, het intermediale karakter van veel voorstellingen en de transformaties die dat oplevert voor de theaterproductiewijze, worden gezelschappen als Toneelhuis in plaats van vernieuwende theatergezelschappen hybride verbeeldingsmachines, die opereren op de grens van theater, literatuur, film, filosofie, dans, muziek, sociale wetenschappen en toegepast artistiek onderzoek.

\section{Theaterlandschap}

Het hybride karakter van de theaterproductie van Toneelhuis Antwerpen en van andere hedendaagse toneelgezelschappen die worden gekenmerkt door Lehmanns postdramatische theatertekens, door Fischer-Lichtes esthetiek van het performatieve en door onderzoek naar het artistiek inzetten van eigentijdse technologie, is een breuk met de literair dramatische theatertraditie. Dit soort breuken als probleem zien of aan de andere kant juist accepteren als kenmerkend voor het hedendaagse artistieke bedrijf, bepaalt het discours over de positie van bestaande theaterinstituties en de inrichting van het theaterlandschap. Het problematiseren van de breuklijn gaat vaak gepaard met pogingen om oude vertrouwde verhoudingen en werkwijzen te herstellen, terwijl acceptatie van de breuklijnen het theaterbedrijf meestal ingrijpend verandert, zoals in het geval van Toneelhuis.

Het organisatiemodel van Toneelhuis, gebaseerd op het verschil tussen de diverse theatermakers, lijkt op een rizomatische verbinding, gekenmerkt door heterogeniteit en veelheid. De verschillende theaterkunstenaars vormen een heterogene verzameling artistieke talen. Het principe van de niet-betekenisdragende breuk, getekend door vluchtlijnen (ander repertoire), territorialiseringen (het incorporeren van videotechnieken, romans, dans, onderzoek), de-territorialisering (afstand nemend van traditionele theatertaal) en re-territorialisering (traditioneel theatrale middelen desgewenst opnieuw inzetten), kenmerkt het vrijelijk omgaan met in beginsel niettheatrale middelen als film, romans, beeldende kunst, dans en video als artistiek richtinggevend voor de theaterproductie. Dit zijn geen absolute breuken met wat theater eens was, maar geïncorporeerde intermediale methoden om te komen tot voorstellingen. Film, soundscapes en video zijn voor het theaterbedrijf vruchtbare vluchtwegen gebleken in het zoekproces naar nieuwe betekenissen, naar nieuwe ervaringen voor performers en toeschouwers in het theater. De recente beweging van 
het weer contracteren van een kleine spelersgroep is een re-territorialisering te noemen, te meer omdat Cassiers er met het oog op internationale samenwerking tevens voor kiest om naast de eerdere innovatieve repertoirekeuzes, ook weer klassiekers uit de toneelliteratuur te gaan regisseren. Het Deleuziaanse principe van de cartografie (kaart en geen kopie), wordt door het Toneelhuismodel impliciet gehuldigd: er is geen structureel voorgeschreven generatief model voor wat een groot gesubsidieerd theatergezelschap zou moeten zijn.

De transformaties van het repertoire en van de organisatie van het gezelschap vormen nog geen ingrijpende verandering voor de bestaande positie van het gezelschap als een van de grootschalige gesubsidieerde theatergezelschappen van Vlaanderen; wel is het een van de grootschalige Nederlandstalige gezelschappen die in toenemende mate internationaal opereren, vooralsnog binnen een internationaal theater-circuit. Het opereren op de grens van kunst, wetenschap en toegepast onderzoek kan bij doorontwikkeling concrete consequenties krijgen voor de positie van gevestigde theatergezelschappen in het bestaande theaterlandschap en op den duur daardoor voor de inrichting van het gehele podiumkunstenlandschap. In dit licht zijn de plannen voor netwerkrelaties op basis van samenwerkingsambities tussen gezelschappen, podia en festivals op Europese schaal, zoals die zijn uitgesproken in de loop van 2013 en 2014 door Cassiers, Simons, Van Hove en anderen, interessant te noemen vanwege de vraag wat er uiteindelijk uit voort zal komen. Het is de vraag of dit soort geambieerde netwerken in het teken zullen staan van het doorontwikkelen van wat op gezelschapsschaal ingezet werd door Toneelhuis Antwerpen of dat de samenwerkingsverbanden aangegaan worden om een bestaande Europese theatertraditie door een peer group van betrokkenen veilig te stellen, te kaderen binnen bestaande internationale theaterkunstgremia. Een en ander zal afhangen van de vraag of de zich doortransformerende performancetekst (Lehmann, 1999, pp. 145), waartoe we gezelschapsorganisatie en institutionele samenwerkingscontext kunnen rekenen als het gaat om de herijking van de relatie tussen performers en toeschouwers, gezien gaat worden als een verzameling breuken met wat theater eens was, of dat deze nieuwe constellaties dynamisch geëxploreerd gaan worden als nieuwe performatieve domeinen. Hierbij hoeven ze dan niet als definitieve breuk in de zin van afscheiding gezien te worden maar als een Deleuziaanse breuklijn, onderdeel van een zich ook buiten de theatersector dynamisch exploratief ontwikkelend kunstenveld. Met andere woorden, ontstaat er het komend decennium een kunstenlandschap van rizomatisch met elkaar verbonden hybride verbeeldingsmachines, waarbinnen het theater een van de subculturele spelers wordt, naast en verweven met performance, media, muziek, dans, filosofie en sociale wetenschap? Of zien we gated theatre communities ontstaan waarbinnen specifieke theatertradities gekoesterd worden als 
een tegenwicht tegenover een negatief uitgelegde explosieve hybridisering van kunst, cultuur en media?

\subsection{Conclusies}

De huidige podiumkunstenpraktijk is minder dominant toneelmatig, minder dramatisch en meer hybride, postdramatisch van aard. Als we spreken over toneel dan hebben we het in Nederland en Vlaanderen inmiddels over een kleine museale niche, zonder daarmee canoniek toneelrepertoire te willen diskwalificeren. Als we kijken naar het gevestigde gesubsidieerde gezelschap Toneelhuis Antwerpen, dan zien we dat de contouren, de constructie en de werking ervan niet meer overeenkomen met het traditionele beeld dat we hebben van wat we na de Tweede Wereldoorlog zijn gaan verstaan onder een grootschalig, gesubsidieerd theatergezelschap: het gespeelde repertoire is anders en dat levert een andere samenstelling en organisatie van het gezelschap op. Geconcludeerd kan worden dat Toneelhuis het afgelopen decennium een aantal transformaties heeft ondergaan met meer en minder impact op de werking ervan in het theaterlandschap van de Lage Landen.

Een transformatie met veel impact is die van het incorporeren van technologische ontwikkelingen en toepassingen in de theaterproductie. In veel voorstellingen van het Toneelhuis is technologie thematisch, vormgevingstechnisch en dramaturgisch van grote invloed; technologie is niet meer uitsluitend dienend en instrumenteel, maar inmiddels artistiek medeconstituerend. Het gezelschap stelt in zijn voorstellingen, met name in die van Cassiers, impliciet artistieke onderzoeksvragen naar de impact en werking van media in een gemediatiseerde samenleving. Met wat wel een herdefinitie van theater genoemd is, draagt het gezelschap bij aan een veranderende theateresthetiek. Beeldtaal en performatieve technologie hebben hun plaats ingenomen naast het talige dramatische als sturend principe en dragen daarmee bij aan een dramaturgie van de nevenschikking. De geënsceneerde romans van Toneelhuis bijvoorbeeld leveren in combinatie met hightechmiddelen een ander soort narrativiteit op dan literair dramatische gestructureerde toneelteksten. Deze grote rol voor de technologie heeft onmiskenbaar invloed op de samenstelling van het gezelschap, op de verhouding van de technische staf ten opzichte van de artistieke en op de onderlinge verhoudingen tussen de artistieke en de technische staf. De beweging die wat dit aangaat bij Toneelhuis gemaakt is in de afgelopen vijftien jaar, is die van de artistieke emancipatie van de theatertechnicus (Fischer, 2006).

Het repertoire van het theatergezelschap is in Lehmann-terminologie te kenschetsen als 'tussen de kunsten'. Met name het intermediale karakter van veel Toneelhuisrepertoire verhevigt de werking van de postdramatische theatrale tekens. Hiermee overstijgt deze aanpak de focus op puur theatrale productie en raakt 
daarmee het performancedomein. Wat Lehmann definieerde als performancetekst, gaat niet alleen op voor het te spelen theaterrepertoire en voor een veranderende theateresthetiek, maar breidt zich uit tot op het niveau van de organisatie van het gezelschap en van het herijkte gebruik van het traditionele podium van de Bourla schouwburg en nieuwe internationale podia.

Het ontslaan van het aanvankelijke spelersensemble in 2006 en het in plaats daarvan aanstellen van een wisselende, divers samengestelde kunstenaarsstaf van individuele kunstenaars en collectieven is een radicale theatertransformatie die het toenemende gewicht van intermedialiteit, onthiërarchisering en interculturaliteit tekent. Het na een aantal jaren weer in dienst nemen van een kleine groep spelers lijkt een beweging terug, maar is het niet. De kleine spelersgroep wordt om artistiek pragmatische redenen aan het kunstenaarscollectief toegevoegd om onder andere een langdurige samenwerking met Toneelgroep Amsterdam en andere Europese theaterinstituties rond het ensceneren van canoniek repertoire mogelijk te maken. De toneelspelersgroep vormt zo een van de kleuren op het palet en niet, zoals voorheen, de hoofdkleur.

Het gezelschap heeft lokaal de intentie om interculturele dialogen te stimuleren. Daarbij is te concluderen dat het gezelschap wel een bindende factor te noemen is in de Vlaamse culturele wereld in het algemeen en in de theatersector in het bijzonder, maar dat het de vraag blijft of het in Antwerpen ook op meer maatschappelijke schaal intercultureel 'hoge' en 'lage' culturen, romantisch burgerlijk beschaafd en digitaal netwerkbeschaafd, westers en niet-westers of diverse andere Antwerpse bevolkingsgroepen bindt. Voor het antwoord op die vraag zal longitudinaal en kwantitatief publieksonderzoek nodig zijn.

In de Vlaamse, de Nederlandse en de Europese kunst- en theatergemeenschap van gelijkgestemde peers is de status van Toneelhuis gevestigd. Dramaturg Erwin Jans sprak in juni 2014 over 2013-2014 als het meest succesvolle seizoen ooit. Hij refereerde daarbij vooral aan de selectie van drie Toneelhuisvoorstellingen voor het jaarlijkse vakfestival in Nederland en Vlaanderen, het Theater Festival ${ }^{86}$, en aan de vele uitnodigingen uit het buitenland. In kunstkringen van New York tot Avignon en van Montréal tot in Berlijn wordt Cassiers' praktijk van de dramaturgie van de nevenschikking onderkend en internationaal groeide de belangstelling voor het

\footnotetext{
${ }^{86}$ De Toneelhuis-voorstellingen Hamlet vs Hamlet (een coproductie van Toneelhuis en Toneelgroep Amsterdam), Notallwhowanderarelost, een voorstelling van en door Benjamin Verdonck (coproductie Koninklijke Vlaamse Schouwburg [KVS] en Toneelhuis), en Van den Vos (coproductie Toneelhuis, Muziektheater Transparant, Liesa van der Aa, FC Bergman, Josse de Pauw \& Solistenensemble Kaleidoscoop), werden in 2014 uitgekozen door de jury van het festival als drie van de twintig meest belangwekkendste voorstellingen van 2014. Hiermee is nog weinig gezegd over absolute publiekscijfers, daar is een grootschalig andersoortig onderzoek voor nodig.
} 
kunstenaarscollectief van Toneelhuis. ${ }^{87}$ Het is echter ook hier de vraag wat het in toenemende mate internationaal opereren en de groeiende belangstelling precies betekenen, met name buiten de peergroup van het gevestigde theatercircuit. Zijn het zelfbevestigende operaties van de betrokken theaterorganisaties binnen een gevestigd en gekaderd internationaal kunsttheatercircuit of leidt de veranderde manier van werken uiteindelijk tot een herijking van het nationale en internationale theater-, performance- en medialandschap? Gaat het om groeiende belangstelling van een internationaal kunstenpubliek van ingewijden of levert het nieuwe repertoire en de nieuwe gezelschapsconstructie nationaal en internationaal ook daadwerkelijk een nieuw soort publiek op, ook buiten dat voor het reguliere gevestigde theater? ${ }^{88}$ De impact van de Toneelhuistransformaties en vergelijkbare processen bij andere theatergezelschappen is nog lang niet over de gehele linie uitgekristalliseerd. De maatschappelijke en culturele diepgang van de culturele footprint van deze theatertransformaties zal pas duidelijk worden aan de hand van uitkomsten van longitudinale publieksonderzoeken.

\footnotetext{
${ }^{87}$ In 2008 werd gepiekt in het buitenland met ongeveer evenveel bezoekers voor Toneelhuisvoorstellingen als in thuisland Vlaanderen, in beide gevallen ging het om 75.000 toeschouwers. In de jaren daarna is gepoogd om het evenwicht met lokale en landelijke opkomst enigszins te herstellen.

${ }^{88}$ Harde cijfers tonen dat er in de eerste twee seizoenen een groei heeft plaatsgevonden van verkochte toeschouwerkaartjes in absolute aantallen: 'Het seizoen 2006-2007 was goed voor 448 voorstellingen voor 85.933 toeschouwers, met 22 producties (18 producties op tournee, 4 enkel in Antwerpen) op 64 speelplekken (31 B, 20 NL, 13 INT) in 9 landen. Het seizoen 2007-2008 kende 522 voorstellingen voor 140.479 toeschouwers, met 18 producties (waarvan 15 op tournee, 3 enkel in Antwerpen) op 100 speelplekken(39 B, 20 NL 41 INT) in 15 landen. De prognose voor het derde seizoen, 2008-2009, liet een kleine correctie naar beneden zien. In het tweede seizoen was er naar eigen zeggen wellicht sprake van een "te hoge vlucht" en stond de organisatie onder een als te hoog ervaren druk' (Toneelhuis, 2008, p.9).
} 


\section{Hoofdstuk 4 Podium in transitie}

‘Op de kop van een grijze tafel spelen oma, dochter en kleindochter een spelletje kaart. Heren in krijtstreep drinken een bedrijfsborrel. Acteurs bereiden zich voor op de komende voorstelling. Aan de leestafel leest een gast het Brabants Dagblad. IJverige kinderen met een lolly in hun mond. Op de loungebanken zit een handjevol jongeren ontspannen onderuit gezakt. Naast hen werkt een vrouw met laptop op schoot. Vanaf de balustrade kijken nieuwsgierige bezoekers naar beneden. Een doordeweekse dag in de Verkadefabriek' (Horen, 2007).

\subsection{Inleiding}

In hoofdstuk 3 hebben we gezien dat de nieuwe theateresthetiek die zich ontwikkelde in de laatste veertig jaar, waarbij allianties gesloten zijn tussen theater, performance en media, effect sorteerde ver voorbij de voorstellingen alleen. Een theatergezelschap als Toneelhuis is daardoor als theaterbedrijf wezenlijk anders van opzet en organisatie geworden dan het gemiddelde theatergezelschap van een paar decennia geleden. Het is in het kader van dit onderzoek naar theatertransformaties de logische volgende stap om na het beschouwen van theaterproducenten, de theaterpodia nader te beschouwen. In het huidige theatersysteem hebben gezelschappen in hun publieke functie zich in de eerste plaats af te vragen op wat voor podia ze zich tot hun publiek gaan richten. Lang was dat een vanzelfsprekende zaak, namelijk in voor dat doel gebouwde theaterzalen, veelal schouwburgen. In Nederland ontstond na de Tweede Wereldoorlog de gedachte dat iedereen kennis moest nemen van hogere cultuur; de overheid ontwierp daartoe verheffingsstrategieën, waaronder het verspreiden over het land van schouwburgen en andere theaterzalen, gesubsidieerde publieke podia waar theaterbezoek centraal stond in een traditie van burgerlijke cultuurbeleving. De gebouwen stonden in iedere stad symbool voor beschaving. Fischer-Lichte stelt dat theaterruimtes, of ze nu tijdelijk zijn opgetrokken of permanent gebouwd, altijd performatieve ruimtes zijn (Fischer-Lichte, 2004, p. 188). De geschiedenis van theaterarchitectuur en van tijdelijke podia zegt alles over de verhouding tussen performers en hun publiek. Deze relatie werd in het theatersysteem van na de Tweede 
Wereldoorlog aanvankelijk sterk gekleurd door de overheidsambities om het volk cultureel te verheffen.

In het vorige hoofdstuk zagen we dat Toneelhuis Antwerpen de verantwoordelijkheid draagt voor de Bourla schouwburg, een groot iconisch te noemen podiuminstituut, en dat het gezelschap dit traditionele podium vanaf de start minder traditioneel ging inzetten. Het gebouw werd min of meer onderdeel van het repertoire, van de werking van de theaterproductie, die de traditionele verhouding tussen performers en publiek transformeerde. In Nederland is de relatie tussen de grote gesubsidieerde gezelschappen en de schouwburgpodia een andere dan in België. De verantwoordelijkheid voor de theaterproductie is formeel gescheiden van die van de theaterdistributie; de podiumtaken in het bestel worden gedragen door de gemeenten. ${ }^{89}$ Dat maakt het structureel artistiek strategisch exploiteren van een gebouw, een podiuminstitutie, door een gezelschap in het kader van een artistiek beleidsplan zoals Toneelhuis dat doet, ingewikkelder. Toch zijn er ook in Nederland wel signalen in de richting van een veranderende inzet van traditionele podia waar te nemen geweest in de afgelopen decennia. ${ }^{90}$

Daarnaast zien we in de huidige culturele context andere podia ontstaan, waaronder we ook internet en festivals kunnen rekenen, met vaak meteen vanaf hun constitutie een intentioneel andere opzet van ambities en werkwijzen. Deze podia worden onder meer gekenmerkt door een diversiteit van de programmering, met als gevolg een confrontatie van culturen, die een ander beeld oplevert dan dat van podiumkunstpresentatie tout court. Ik wil in deze gevalstudie naar het theaterpodium met name onderzoeken hoe de transformatie van de werking van dergelijke podiuminstituties eruit ziet. Wat zijn deze nieuwe podia en wat doen ze precies? Hoe wordt hun relatie met producenten en publiek gekenmerkt? Daarbij staat de vraag centraal hoe interculturaliteit op dergelijke plekken vorm krijgt. Het object van onderzoek is de Verkadefabriek in 's-Hertogenbosch. Dit relatief nieuwe podium (2004) is exemplarisch voor de functietransformatie van hedendaagse podia, onder meer vanwege het hergebruik van industrieel erfgoed, de diversiteit van de programmering, de functie van het podium in de regio en het door de directie beleden uitgangspunt van cultureel ondernemerschap.

In paragraaf 4.2 beschrijf ik een aantal richtinggevende actoren (gebouw, caférestaurant, theaterzalen, repetitielokalen, filmzalen, de programmacategorie Woord, festivals en bedrijfsvoering) die als voorwaardenscheppers de werking van de Verkadefabriek kenmerken. Ik sprak daarvoor een aantal malen met directeur Jan van der Putten, nam interviews af met medegebruikers van het gebouw zoals zakelijk directeur van het festival November Music Theo van Dooremalen, artistiek directeur

\footnotetext{
${ }^{89}$ Meer over de relatie tussen schouwburgen, theatergezelschappen en cultuurbeleid in hoofdstuk 6.

${ }^{90}$ Verderop in dit hoofdstuk besteed ik daar meer aandacht aan.
} 
Madelein Matzer van theatergezelschap Matzer Producties, artistiek leider van het toen nog operationele Productiehuis Brabant Piet-Jan Dusee en met de toenmalige Bossche wethouder van Cultuur Rodney Weterings. Ook bezocht ik gericht over een langere periode diverse programmaonderdelen en festivals in de Verkadefabriek. Daarnaast heb ik gebruikgemaakt van jaarplannen en publicatiemateriaal in druk en op internet. Vervolgens zal ik in paragraaf 4.3 voor een analyse vooral gebruikmaken van Latours Actor Network Theory (ANT), met name van zijn begrippen intermediair en mediator, en transportation en translation. In paragraaf 4.4 trek ik conclusies over het transitieproces dat veel eigentijdse podia kenmerkt.

\subsection{De Verkadefabriek in 's-Hertogenbosch}

'De Verkadefabriek gelooft dat creativiteit en een open blik menselijke eigenschappen zijn die bijdragen aan een betere samenleving en wil een plaats in de stad zijn waar dat bevorderd wordt en waar mensen van verschillend pluimage voor hun plezier komen en elkaar ontmoeten' (Verkadefabriek, 2010, p.3).

Hergebruik van industrieel erfgoed

De Verkadefabriek is gevestigd in een voormalige koekjesfabriek van de firma Verkade en gelegen vlak bij het Centraal Station van 's-Hertogenbosch. De koekjesfabriek was sinds 1990 opgenomen in de holding United Biscuits en kwam vanaf 1993 grotendeels leeg te staan omdat de holding haar productie elders ging concentreren. In 2001 werden in het gebouw met succes een aantal locatievoorstellingen van het project Varkens/Boeren opgevoerd door het toenmalige Eindhovense theatergezelschap ZT Hollandia, onder leiding Johan Simons en Paul Koek. Voorafgaand aan de voorstellingen kon worden gegeten in een voor de gelegenheid ingericht tijdelijk restaurant, kenmerkend voor de aanpak van ZT Hollandia. ${ }^{91}$ In 2002 bracht het Bossche jeugdtheatergezelschap Artemis er de grootschalige theaterproductie Katharina Katharina in het ganzenbord. Voor velen in en rond Den Bosch werd vanaf die tijd duidelijk dat de fabriek kansen bood om de stad te verrijken met een tot de

\footnotetext{
${ }^{91}$ Per 1 januari 2001 trad toentertijd een nieuw landelijk vierjaren kunstenplan in werking. Per die datum kregen Johan Simons en Paul Koek de leiding over het in Eindhoven gevestigde repertoiregezelschap Het Zuidelijk Toneel, een van de grotere gesubsidieerde gezelschappen van Nederland. Het werd een fusie van het gezelschap van Simons en Koek, Hollandia, en Het Zuidelijk Toneel. Ze veranderden de naam in ZT Hollandia (Zuidelijk Toneel Hollandia). Een van de eerste grootschalige projecten van het fusiegezelschap was het Varkens/Boeren-project in 2001. Dit project bestond uit een aantal voorstellingen zowel in gevestigde theaters als op locatie (Truus en Connie, Nageslacht), een serie lokale televisiecolumns, een uitgebreid educatieproject rond de voorstellingen en dit alles gethematiseerd rond de impact van de varkenspestepidemie van 1997 op de Brabantse samenleving.
} 
verbeelding sprekend podium. Vanuit het bestaande vlakkevloertheater Theater Bis werd in samenspraak met de gemeente en met lokale en regionale betrokkenen gewerkt aan een concept waarin een theaterpodium, een filmhuis, het werk van producerende theatermakers en een levendige horecagelegenheid samen zouden kunnen gaan in wat vanaf de eerste plannen een innovatieve culturele ontmoetingsplaats moest worden.

In februari van 2002 besloot de Bossche gemeenteraad tot verbouw van het industriële pand tot een kunstencentrum voor theaterprogrammering, horeca, film en podiumkunstenproductie. De verbouwing werd uitgevoerd door Bierman Henket architecten, een bureau dat in die periode naam maakte met het verbinden van ouden nieuwbouw. Dit hergebruik van industriële panden is in de postindustriële periode aan het eind van de twintigste en het begin van de 21 e eeuw overigens op grote schaal gebruikelijk, zeker hergebruik voor culturele doeleinden (Hospers \& Timmerman, 2001; Ackerman \& Hendriks, 2010; Lehmann, 1999). Zo zijn de afgelopen decennia veelvuldig grootschalige verbouwprojecten gerealiseerd in bijvoorbeeld voormalige scheepswerven, krachtcentrales en fabrieken in vrijwel de gehele westerse wereld. Enkele tot de verbeelding sprekende voorbeelden zijn te vinden in het Duitse Ruhrgebied met zijn industrieel erfgoed van enorme omvang: Zollverein (Essen), Jarhhunderdhalle (Bochum), Kokerei Hansa (Dortmund); in Zwitserland Schiffbau (Zürich); in Groot-Brittannië Tate Modern (Londen); in Nederland het Westergasfabriek-terrein in Amsterdam, de Witte Dame en Strijp-S in Eindhoven.

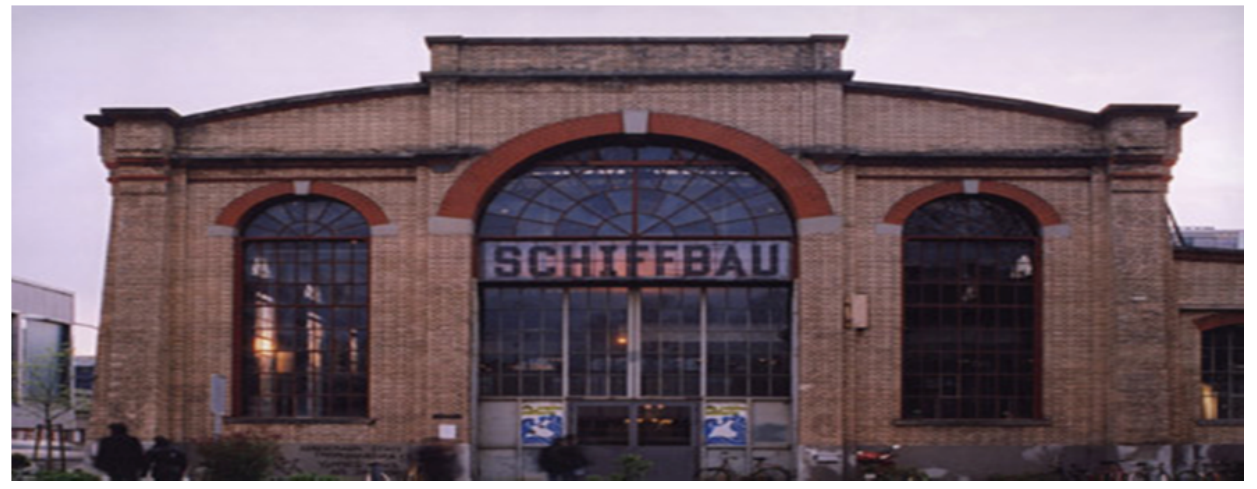

Fig. 7 Schiffbau, Zürich. (foto H. Havens, 2011)

Op 28 september 2004 opende acteur Bert Luppes de Verkadefabriek met de speciaal voor de gelegenheid hernomen theatermonoloog Kingcorn..$^{92}$ Vijf jaar later, in september 2009, werd er feest gevierd bij het eerste lustrum. In die eerste vijf jaar

\footnotetext{
${ }^{92}$ Een voorstelling van Theatergroep Hollandia in seizoen 1997/1998.
} 
hebben er ongeveer twintigduizend activiteiten plaatsgevonden en hebben een kleine miljoen bezoekers uit 's-Hertogenbosch, Noord-Brabant en de rest van Nederland hun weg naar het podium gevonden. Vanaf de start zijn een aantal 'huisgenoten', gebruikers van het pand, onder één dak verenigd. Onder de Stichting Verkadefabriek vallen: theaterprogrammering in een grote en in een kleine theaterzaal; filmprogrammering aanvankelijk in drie en later in vijf filmzalen; theaterproductie aanvankelijk door de Wetten van Kepler en het Productiehuis Brabant, later door Matzer en amateurtheaterschool Picos; de festivals Boulevard en November Music, plaatselijk jongerenfestival B-there, structurele samenwerking met festivals van elders in Nederland (Festival Cement, IDFA, het literaire Geen Daden Maar Woorden-festival); een divers kinderprogramma en een lokaal politiek-cultureel debatprogramma. De professionele horecavoorzieningen zijn ondergebracht in een separate horecaorganisatie, de BV Koekjesfabriek (bar, foyer, café en restaurant). ${ }^{93}$

Op basis van de publiekscijfers en de jaarverslagen kon geconcludeerd worden dat het totaalconcept van de Verkadefabriek de eerste vijf jaar van haar bestaan geslaagd was. De filmprogrammering doet het over de gehele lijn zo goed dat er in de loop van 2008 en 2009 twee nieuwe filmzalen bijgebouwd zijn. ${ }^{94}$ De horecavoorzieningen, café, foyerwerking en restaurant blijken een aanvulling op het café-restaurantaanbod van de stad Den Bosch. Met sommige van de festivalpartners verloopt de structurele samenwerking uitstekend, met andere moeizamer. Het kansen schenken aan nieuw theatertalent via het Productiehuis Brabant verloopt de eerste jaren redelijk tot goed. ${ }^{95}$ In de laatste categorie is sprake van een groeiende schare prosumenten, een publiek samengesteld uit collega's, coproducenten en vrienden en bekenden van artistiek actieven, mensen die zelf ook op een of andere manier

\footnotetext{
${ }^{93}$ Vanaf de opening in 2004 hebben op cultuurbeleidsmatige ijkmomenten, zoals het ingaan van nieuwe nationale cultuurnotaperiodes op 1 januari 2009 en 1 januari 2013, veranderingen plaatsgevonden in de samenstelling van de groep huisgenoten van de Verkadefabriek. De stopzetting van de landelijke subsidie aan het theatergezelschap De Wetten van Kepler per 31 december 2008, heeft bijvoorbeeld geleid tot de opheffing van dat gezelschap. Daarvoor in de plaats kwam het jonge gezelschap Matzer, rond regisseur Madeleine Matzer, in de Verkadefabriek werken. Per januari 2013 stopte de landelijke subsidie van Productiehuis Brabant; het herformeerde zich onder andere condities en verhuisde naar Tilburg.

${ }^{94}$ De Verkadefabriek hoort qua bezoekersaantallen tot de top 10 van de best bezochte filmtheaters in Nederland (Verkadefabriek, 2009, p.5).

${ }^{95} \mathrm{Na}$ de verkiezingen van juni 2010 en de implementatie van nieuw cultuurbeleid door de nieuw gevormde regering, gebaseerd op de veranderde politieke verhoudingen, is de positie van de productiehuizen verslechterd. Per 1 januari 2013, bij het in werking treden van de nieuwe kunstenplanperiode 2013-2016, worden de subsidies aan alle productiehuizen in Nederland gestopt. Na het bekend worden van het bezuinigingspakket op cultuur is de ambitie voor wat betreft talentontwikkeling opnieuw geformuleerd in Toekomstvisie Verkadefabriek (Verkadefabriek, 2011, p. 5). Daarin wordt uitgegaan van een samenwerking op dit vlak van het onttakelde Productiehuis Brabant dat in afgeslankte vorm naar Tilburg verhuisde, met de Verkadefabriek, met het theatergezelschap het Zuidelijk Toneel in Tilburg, en met Theaterfestival Boulevard.
} 
betrokken zijn bij de podiumkunstensector of aanpalende gebieden. ${ }^{96}$ Het succes had onder meer te maken met een openlijk beleden cultureel ondernemerschap als het gaat om het verleiden van verschillende soorten publiek door een prettige uitgaanssfeer in combinatie met een duidelijke keuze voor het meer kritische en geëngageerde deel van het film- en podiumkunstenaanbod. Hiermee bewees de nieuwe locatie zichzelf als culturele ontmoetingsplek voor een divers samengesteld publiek en werd de Verkadefabriek ook door beleidsverantwoordelijken gezien als belangrijk cultureel podium voor Den Bosch en omgeving. In bestuurlijke kringen werd het succes zowel lastig als prettig gevonden. Lastig omdat de duurdere plaatselijke schouwburg Theater aan de Parade cultuurbeleidsmatig minder productief bleek, afgezet tegen het succes van het nieuwe podium. Prettig, omdat de stad 'sHertogenbosch zich ermee profileerde als een stad met beleidsruimte voor een meer eigentijds podium dat zich anders probeerde te positioneren dan als een podium ter verheffing van het volk. Volgens toenmalig wethouder van Cultuur (PvdA), Rodney Weterings, voorstander van deze koersverandering en ambtelijk verantwoordelijk voor gemeentelijke besluitvorming rond de podia van 's-Hertogenbosch, is de functie van podia in de hedendaagse culturele context aan verandering onderhevig:

RW: In dit verband zou je eigenlijk de term podium los moeten laten. Want de schouwburg is hier ook het paleis van prins Amadero de zoveelste in het kader van carnaval, in die zin eigenlijk een traditioneel gemeenschapshuis in het centrum van de stad. Terwijl de Verkadefabriek veel meer een eigentijdse ontmoetingsplek is en veel meer een marketingconcept om publiek aan je te binden dat soms komt voor toneel of film, maar dat vooral komt om elkaar te ontmoeten. Het heeft een heel ander soort functie in de stad. (...) We hebben hier een goed draaiende amateurkunstsector, een bibliotheek, een stadsschouwburg en dat zijn allemaal uit die overheid voortkomende instituties, die allemaal appelleren aan traditionele opvattingen over de verheffing van het volk.

$\mathrm{HH}$ : Wat Paul Schnabel dood heeft verklaard.

RW: Ja, en wat in de jaren tachtig begon af te kalven. (...) Er is nog verrekte veel te verheffen, vind ik zelf ook, maar niet meer op de manier waarop we dat in het verleden gewend waren. (...) Dat gebeurt nu op andere plekken, nou ja, precies, en de Verkadefabriek was voor Den Bosch een vroege manier van zo kijken en organiseren

\footnotetext{
${ }^{96}$ In november 2009 startte onder leiding van Karin Wenz (Faculteit Cultuur- en Maatschappijwetenschappen van de Universiteit Maastricht), een omvangrijk door NWO gefinancierd onderzoek naar deze prosument-categorie onder de cultuurconsumenten. Prosumenten zijn mensen die bij een bepaalde activiteit aspecten van producentschap en van consumentschap in zich verenigen. Het woord is een samentrekking van producent (producer) en consument (consumer). De titel van het onderzoek luidt: Narrative fan practices: A key to cultural dynamics.
} 
en dus ook financieren. Het is voor ons ook een impuls geweest, samen met Jan van der Putten. Hij tart ook voortdurend ons systeem door zijn manier van werken. Bijvoorbeeld over cultureel ondernemerschap, nu vindt iedereen Jan een cultureel ondernemer. De gemeenteraad vindt hem ook vooral een cultureel ondernemer die geld verdient, nou ja, dat vind ik eigenlijk het minst interessant aan het cultureel ondernemerschap. ${ }^{97}$

Om de veranderende functie en de werking van de Verkadefabriek als podium te onderzoeken beschrijf ik hierna hoe de actoren zich in het proces gedragen, hoe ze als het ware gezamenlijk de voorwaarden scheppen en vormgeven voor de concrete werking van de podiuminstitutie. Ik onderzoek eerst hoe het gebouw als podium werkt door de verschillende functies op een aantal momenten en tijdens verschillende onderdelen van de programmering te beschrijven. Daarna besteed ik aandacht aan de leidinggevenden en aan de bedrijfsvoering als actoren in de werking van het podium.

\section{Gebouw}

Het industriecomplex in Den Bosch is door prof. ir. Hubert Jan Henket met moderne materialen (staal, kunststof, glas) herontworpen. Het gebouw als geheel oogt open door alle glaspartijen en kent nauwelijks opsmuk. Bij deze herinrichting zijn oud en nieuw architectonisch in elkaar opgegaan. Naast facilitaire ruimtes voor café- en restaurantpersoneel, keuken, bar en administratieve kantoorruimtes, is er ook een aantal publieksruimtes.

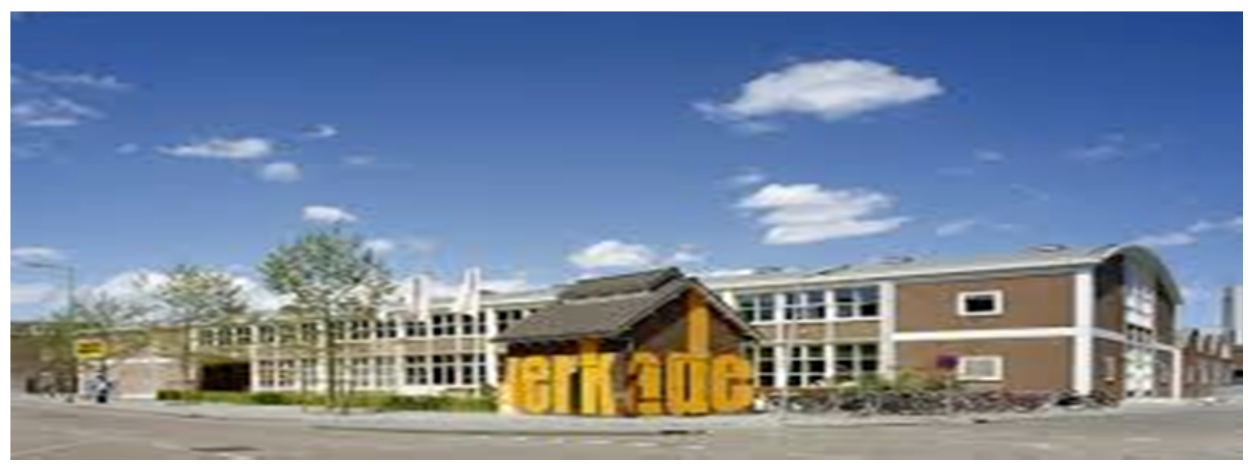

Fig. 8 Verkadefabriek, 's-Hertogenbosch (foto Bierman Henket architecten)

\footnotetext{
${ }^{97}$ Interview met de toenmalige Wethouder van Cultuur van 's-Hertogenbosch, Rodney Weterings op donderdag 7 januari 2010. [digitaal audio bestand] (transcriptie H.Havens). Weterings vertrok begin november 2011 na vijf en een half jaar als wethouder. De laatste periode met de portefeuille Volkshuisvesting, welzijn en cultuur.
} 
De Verkadefabriek telt vijf filmzalen, een grote (150 stoelen) en vier kleine $(55,55,77$, en 47 stoelen) en twee theaterzalen, een grote ( 270 stoelen) en een kleine (106 stoelen op telescooptribune). Tevens huisvest het gebouw drie repetitielokalen, in gebruik bij theaterproducerende huisgenoten. Door sommige festivals, die in of vanuit het gebouw worden geprogrammeerd, worden deze repetitiezalen ook ingezet als publieksruimte. Aan de buitenkant is op verschillende plaatsen met metershoge grafische lettertableaus de naam VERKADEFABRIEK geschilderd en aan de zijde die naar de spoorlijn is gekeerd, is over de gehele gevel een opvallende, abstracte lichtkrant gerealiseerd. De spoorlijn is de drukste noord-zuidverbinding van Nederland en per dag zijn door de lichtkrant ongeveer 35.000 tot 50.000 treinreizigers in de gelegenheid om te zien wat er in het gebouw aan de hand is.

Een aantal oorspronkelijke elementen is in het herontwerp bewaard gebleven. Opvallend is het zogeheten sheddak, dat maakt dat vrijwel in het gehele gebouw daglicht binnen valt. ${ }^{98}$ In het café-restaurant is de vloer bedekt met de originele gele fabrieksvloertegels, die allemaal eerst verwijderd werden, schoongemaakt en vervolgens weer teruggelegd. Tevens zijn kleine delen van de wanden in het caférestaurant betegeld, met geglazuurde, hygiënisch witte tegels, die verwijzen naar ruimtes waar voedsel (koekjes) geproduceerd werd.

Het gebouw wordt op de begane grond kruislings doorsneden door twee brede gangen. De gangen hebben een strakke, in moderne kleuren geschilderde, betonnen vloer, geen negentiende-eeuwse chique, geen over the top design, maar functioneel en gemakkelijk in onderhoud. De ene gang (noord-zuid) loopt van de hoofdingang aan de voorkant dwars door het gebouw naar de achterkant, waar zich een uitgang/ingang bevindt die uitkomt op het parkeerterrein. Aan deze gang zijn de toegangsdeuren tot drie filmzalen, tot een grote toiletgroep, er bevindt zich een centrale kassa en een betaalautomaat voor het parkeerterrein, de toegang tot de twee kleinere filmzalen en een daarmee verbonden kleine foyer en een garderobevoorziening. In de andere gang, de dwarsgang, bevindt zich aan de ene kant een grote publieksruimte met horecavoorzieningen, die vaak dienst doet als foyer voor de grote theaterzaal. Als vanaf deze foyer de andere gang recht wordt overgestoken, loopt de dwarsgang verder door naar de drie werk- en repetitieruimtes van de producerende huisgenoten. Voorts bereikt men het café-restaurant, een kleine vergaderruimte die verhuurd wordt onder de naam Expeditie en een door een glazen wand afgeschermde trappartij naar de eerste verdieping. In de gangen en halpartijen hangen wisselende fototentoonstellingen en verspreid door het gebouw staan op functionele plekken grote ruwhouten meubels van de Nederlandse ontwerper Piet Hein Eek, die furore

\footnotetext{
${ }^{98}$ Sheddak, (o) [gevormd van Eng. Shed (loods, afdak), een specifieke toepassing van shade(schaduw)], zadeldak met twee schuine vlakken, één flauw, de ander steil hellend, waarvan het steile dakvlak voorzien is van glazen lichtopeningen, synoniem: zaagdak (Van Dale, 1999).
} 
maakt met meubels van hergebruikt sloophout. Deze keuze voor Eek onderstreept het hergebruik van het gehele gebouw en tegelijkertijd verwijst het naar een wereld van gevestigd Nederlands design. Het past binnen de visie van de organisatie over de plaats van kunst in de samenleving: 'De Verkadefabriek doet gewoon over kunst. Voor ons is kunst een onderdeel van het dagelijks leven. Niets om hoogdravend over te doen. Kunst moet communiceren en iets te vertellen hebben over het hier en nu' (Verkadefabriek, 2009, p. 6).

\section{Café-restaurant}

Café-restaurant, woensdag 12 mei 2010, 11.15 uur. Een doordeweekse voorjaarsdag, om 11.00 uur heeft de Verkadefabriek haar deuren geopend. Vijf jonge mannen en vrouwen zitten aan het uiteinde van een van de drie ruwhouten tafels in het caférestaurant. Er liggen notitieblokken op tafel, losse papieren, hun laptops zijn open, mobieltjes bij de hand; ze werken. Aan een andere tafel zitten zes vrouwen op leeftijd aan koffie met gebak. Personeel doet wat personeel van een horecagelegenheid doet in de ochtend: iemand vervangt een kapotte lamp op het terras, lege dozen worden afgevoerd, gasten worden voorzien van koffie, thee, gebak.

Het restaurant is een kale, betegelde, langwerpige ruimte met een opengewerkt plafond. Boven de hoofden van de gasten is op de eerste verdieping een vide, een galerij langs alle toegangsdeuren van de kantoorruimtes van de in het gebouw gevestigde organisaties. Midden in dit 'gat' in het plafond hangen drie grote, modern vormgegeven roze lampen. ${ }^{99}$ Aan het plafond zijn elektriciteitsleidingen, luchtverversingssystemen, verwarming en technische zaken voor de geluidsinstallatie in alle openheid te zien. Het versterkt het idee dat de gasten zich bevinden in een voormalig industrieel pand. Aan het plafond hangen Icd-schermen; ze geven wisselende informatie over voorstellingen en films in de Verkadefabriek. Van alle kanten valt daglicht binnen door glaswanden, een aan de lange straatzijde, een die het restaurant scheidt van een personeelsruimte en een die het restaurant scheidt van een corridor met de repetitieruimtes.

In het restaurant zijn, in één grote, open ruimte, een aantal compartimenten met verschillende sferen gemaakt. Men dient zich voor een zitplaats bij het bedienend personeel te melden bij een entreedesk. Voor een maaltijd kan niet gereserveerd worden, behalve voor gezelschappen groter dan zeven personen. De kaart wordt regelmatig vernieuwd en is niet spectaculair; het restaurant voldoet als omlijstende service rond publieksactiviteiten als festivals, filmvertoningen en dans- en theatervoorstellingen.

\footnotetext{
${ }^{99}$ Later, in 2012, zie ik andere enorme lampen of lichtsculpturen. Er wordt klaarblijkelijk regelmatig gewisseld van lichtarmaturen met een zekere designwaarde.
} 
Het café-restaurant heeft een vrij toegankelijk wifi-netwerk. Men heeft ervoor gekozen om verschillende verlichtingssystemen naast elkaar te gebruiken: grote koperen lampen boven de leestafel, kleine moderne lampjes in het restaurantdeel, modern ogende, fel oranje kunststof hanglampjes zijn later toegevoegd boven salontafels en loungehoek, en vierkante sfeerlampen boven de zithoeken achter de bar. Hier en daar staan op strategische plekken metalen jarendertigkapstokken. De tafeltjes en stoelen zijn van een combinatie van metaal en hout. Op reguliere avonden mengen zich verschillende publieksgroepen voor restaurant, film en theater in de ambiance van een druk bezocht café.

Woensdag 12 mei 2010, 13.30 uur. De dames op leeftijd zijn verhuisd van het café naar het restaurant en zijn mijn buren geworden als ik lunch samen met ongeveer zestig andere gasten. Het publiek is gemengd, oud en jong, trendy types, mensen die tijdens hun lunch doorwerken, eenlingen, koppels en een paar grotere groepen.

\section{Theaterzalen}

De grote en de kleine theaterzaal zijn allebei zogeheten vlakkevloerzalen, dat wil zeggen dat er sprake is van een opstelling waarbij het publiek van bovenaf naar het speelvlak kijkt. Dramaturg Rob Klinkenberg noemt de opkomst van dit vlakkevloertheater in Drie kluiten op een hondje. Klein lexicon van het theater een van de 'belangrijkste ontwikkelingen in het theater van de tweede helft van de twintigste eeuw' (Klinkenberg, 2005, p. 193). Voor het inrichten en faciliteren van de twee theaterzalen hebben de ontwerpers en de theatertechnici vooraf studie gemaakt van voorbeeldzalen in Haarlem en Tielt (Vlaanderen). Achter in beide theaterzalen bevindt zich de zogenaamde regiecabine, waarvandaan licht, geluid en andere technische zaken tijdens de voorstelling gereguleerd kunnen worden. Over het gehele plafond is een grid aangebracht, voor lampen, beamers, geluidsapparatuur en dergelijke. Het grid is goed bereikbaar voor de technici door diverse loopbruggen. ${ }^{100}$ De kleine zaal is onder het grid 5,40 meter hoog. Boven het grid is alles zwart geschilderd, eronder zijn de muren goudkleurig; de zaal wordt ook wel de 'gouden zaal' genoemd. De grote zaal is onder het grid 7 meter hoog en boven het grid ook zwart, daaronder hebben de muren een onbestemde groengrijze kleur. Volgens de gebouwenbeheerder is er gezocht naar een kleur die het soms hevige halogeenlicht zo neutraal mogelijk terugkaatst. De muren zijn van boven naar beneden en rondom de zaal af te dekken

\footnotetext{
${ }^{100}$ Grid: Stelsel van buizen vlak onder het plafond van een vlakkevloertheater, kruisgewijs opgehangen, vandaar de Engelse naam die echter op zijn Nederlands uitgesproken dient te worden. Het grid wordt met name gebruikt om er lampen aan op te hangen. In zijn meest chique versie bestaat het grid uit een aantal loopbruggen waarop de technicus met de lampen kan lopen, maar gewoonlijk moeten de lampen vanaf de vloer aan de buizen gehangen en gesteld worden.' (Klinkenberg, 2005, p.74).
} 
met donkere gordijnen. ${ }^{101}$ De speelvloer van beide zalen is een parketvloer, die niet eerbiedig ontzien wordt. De medewerker gebouwbeheer verzekerde me dat als er voor een voorstelling schroeven in de vloer moeten, die schroeven erin gaan. Vóór de wanden van de zaal is rondom het speelvlak een tweede wand geplaatst, zodat performers of technici ongezien rondom het speelvlak van de ene kant naar de andere kant kunnen komen. Bovendien kunnen door diverse deuropeningen performers opkomen en afgaan en kan er voor allerlei andere doeleinden van deze omloop gebruikgemaakt worden.

Donderdag 27 mei 2010, 20.30 uur. Theatervoorstelling De Caracal door Hummelinck Stuurman Theaterproducties (HST). HST is een niet-gesubsidieerde Nederlandse theaterproducent. Het stuk is gebaseerd op een tekst van Judith Herzberg en werd eerder al uitgebracht. ${ }^{102}$ Het is een solovoorstelling geregisseerd door Michiel van Erp, die bekender is van zijn documentaires dan van zijn theaterwerk. ${ }^{103}$ Voor het theater heeft hij veel samengewerkt met het Nederlandse theatergezelschap Mug met de gouden tand. Hoofdrolspeelster in De Caracal is Olga Zuiderhoek, zij was in het verleden een van de actrices van het roemruchte Nederlandse gezelschap Het Werkteater. ${ }^{104}$ Het publiek dat foyer van de grote zaal binnendruppelt, is van een generatie die het Het Werkteater nog heeft kunnen zien spelen. Er is één jongen van begin twintig bij. Bij navraag komen de meeste mensen naar deze voorstelling voor Zuiderhoek. Er zitten mogelijk ook fans van het literaire werk van Judith Herzberg. Het lijkt een publiek van traditionele cultuurliefhebbers, ze zijn gekomen voor theaterfurore, zo is op te maken uit gespreksflarden voor aanvang.

In een zaal van bijna driehonderd stoelen zitten ongeveer honderd toeschouwers voor een reguliere culturele gebeurtenis. Ze kijken naar een professionele actrice, die een vrouw speelt die de gehele voorstelling op een humorvolle manier met een smartphone belt of gebeld wordt. De essentie van de voorstelling is dat ze met heel

\footnotetext{
${ }^{101}$ Medewerker gebouwbeheer Hein van Boxtel, woensdag 12 mei 2010

102 Judith Herzberg schreef De Caracal in 1988 in samenwerking met Motti Averbuch voor de actrice Marjon Brandsma, die het speelde in een regie van Gerardjan Rijnders.

${ }^{103}$ Tot het bekende werk van Michiel van Erp horen onder andere de documentaires: Beatrix, Majesteit (2009); Erwin Olaf, On Beauty and Fall (2009); Angst (2009); Welkom in Nederland (2007-2008); Profiel: Gerrit van der Valk (2006); hij maakte films over de uitvaart van Prins Claus Op handen gedragen (2003), over Connie Palmen, Op zoek naar de heilige tijd (2005) en over de Zangeres Zonder Naam Vergeet me niet (2002).

${ }^{104}$ Het Werkteater was van 1970 tot 1985 een baanbrekend en legendarisch Nederlands theatergezelschap. Leden waren naast Olga Zuiderhoek: Shireen Strooker, Helmert Woudenberg, Joop Admiraal, Gerard Thoolen, Yolande Bertsch, Cas Enkelaar, Frank Groothof, René Groothof, Daria Mohr, Rense Rooyaards, Herman Vinck, Hans Man in 't Veld, Peter Faber en Marja Kok. Het Werkteater was roemrucht door een vernieuwende aanpak van repetitieprocessen, de geëngageerde manier waarop hun repertoire tot stand kwam en door de manier waarop ze hun publiek opzochten. Retrieved February 15, 2015, from http://www.werkteater.nl/
} 
veel mensen belt, maar dat ze dat ene telefoontje warop ze wacht, niet krijgt. Door deze gesprekken met figuren uit haar omgeving maar ook met wildvreemden, krijgen we een beeld van een vrouw en haar leven. Een belangrijk facet aan deze versie van de voorstelling is een op de achtergrond geprojecteerd beeld van een, soms wisselend, uitzicht op een nachtelijke Amsterdamse straat. We kijken vanuit een raam ergens op de eerste of tweede etage neer op de stoep van de straat, inclusief vuilniszakken, fietsen, geparkeerde auto's en een sporadisch passerende fietser of voetganger.

Als de voorstelling is afgelopen, na een korte anderhalf uur, is er uitbundig applaus. Men kent de codes, men bewondert de actrice met de niet geringe staat van dienst. Zuiderhoek moet een keer of drie, vier terugkomen om het applaus in ontvangst te nemen. Als het stiller wordt, verlaat men gedisciplineerd de zaal. Hier en daar vang ik bewonderende opmerkingen op. Weinigen blijven hangen, men zoekt zijn jas op en verlaat het pand. In het café is het voller en luidruchtiger dan toen we de voorstelling ingingen.

\section{Repetitielokalen}

De repetitielokalen zijn kleine varianten van de theaterzalen. De muren zijn rondom af te dekken met zware, donkere gordijnen. Over het gehele plafond is een eenvoudig grid aangebracht en ook de regiefaciliteiten zijn in overeenstemming met de afmetingen van de ruimte. Op de vloeren ligt parket en er staan geen vaste maar losse en kleinere publiekstribunes. Regelmatig worden de repetitieruimtes ingezet als publieksruimte.

Vrijdag 28 mei 2010. Bel me, een jongerenvoorstelling van jeugd-en amateurtheaterschool Picos, die een onderdeel is van De Muzerije, het cursushuis voor de amateurkunst van de gemeente 's-Hertogenbosch. Picos is een van de in de Verkadefabriek producerende huisgenoten.

19.30 uur. Op een vol en zonovergoten terras drinken mensen in de vooravond koffie, bier of wijn. Trendy publiek vermengt zich met jongeren in de puberleeftijd en groepjes en paren van middelbare leeftijd. Er vormt zich druppelsgewijs een groep voornamelijk jonge meiden. Ze hebben allemaal een roos bij zich. Sommigen zijn vergezeld van een ouder iemand of juist van jongere kinderen. Ik schat in dat het hier gaat om vrienden, broertjes en zusjes en andere familieleden van de zo dadelijk optredende jongerenamateurs van Picos.

20.00 uur. Zo'n tachtig mensen vullen het kleine zaaltje dat tevens de repetitieruimte van Picos is. Zwarte gordijnen rondom, functionele belichting, uitgebreid met vanachter het speelvlak op het publiek gerichte spots. Er klinkt popmuziek, die abrupt stopt als een van de spelers haar telefoon opneemt. Voor de 
tweede keer in één week zie ik een theatervoorstelling die volledig draait rond communicatie via mobiele telefonie.

De voorstelling wordt gespeeld door dertien pubers en een volwassen man, amateurs geregisseerd door Rose-Marie Bedaux. Hier doen ze hun eerste buitenschoolse theaterervaringen op. Ze zijn bovendien als prosumenten in de gelegenheid om zich in hetzelfde gebouw te informeren bij de professionele vakbroeders van Matzer en van het Productiehuis Brabant. Ze laten zich inspireren door het geprogrammeerde theater- en dansaanbod van de Verkadefabriek. Dit geldt overigens voor de meeste actieven in en om de Verkadefabriek. Men wil elkaars voorstellingen zien en het is voorstelbaar dat gezamenlijk genoten voorstellingen en films inspirerend en engagerend werken.

\section{Filmzalen}

De filmzalen zijn alle vijf kleine, standaard filmzalen. Ze hebben comfortabele stoelen, de wanden zijn versierd met een kleurig decoratief patroon dat verwijst naar de geschiedenis van het gebouw: wafels en koekjes. In de loop van 2012 wordt een proces van digitalisering van de filmprojecties voltooid. Deze digitalisering brengt kansen met zich mee voor ander aanbod dan voorheen mogelijk was: filmvertoningen op verzoek, combinaties met nieuwe media, openluchtfilmvertoningen en het realiseren van eigen producties. 'Er zal meer on demand beschikbaar komen en er kan maatwerk geleverd worden' (Verkadefabriek, 2012). Hiermee kunnen nieuwe publieksgroepen en nieuwe performatieve domeinen aangesproken worden.

De filmprogrammering kan gekenschetst worden als arthouse-plus. Alle filmvertoningplekken in Nederland zijn vanaf 2008 aangesloten bij de Nederlandse Vereniging van Bioscoopexploitanten. Deze vereniging hanteert een functionele indeling in drie categorieën: 1 . grote bioscopen die in een of meerdere grote zalen voornamelijk Amerikaanse blockbusters en Nederlandse publieksfilms programmeren; 2. de kleine arthouse-zalen en organisaties voor de kleine artistieke film en voor een deel van de documentaireprogrammering; 3 . de filmtheaters met een divers soort van programmering. De Verkadefabriek valt onder categorie 3, die van de filmtheaters. De filmtheaters worden weer onderverdeeld in drie categorieën: A. groter dan twee zalen met een dagelijks filmaanbod (ongeveer twintig in Nederland); B. een of twee zalen met een dagelijks filmaanbod (ongeveer dertig in Nederland); C. filmtheaters met minimaal één filmvertoning per week (ongeveer zestig in Nederland, veelal ondergebracht bij culturele centra, grote bioscopen, wijkcentra of scholen). De Verkadefabriek behoort met haar vijf filmzalen tot categorie A van de filmtheaters en was in $\mathbf{2 0 0 9}$ met ongeveer vijfduizend filmvertoningen per jaar op drie na het 
filmtheater met de grootste afzet van die categorie in Nederland. ${ }^{105}$ De programmering is overwegend een verzameling van niet-Amerikaanse, Europese en niet-westerse films, te vergelijken met het aanbod van het Internationaal Film Festival Rotterdam (IFFR).

Een voorbeeld van een vernieuwende filmprogrammering in de Verkadefabriek is Upload Cinema, een vorm van podiumgebruik die op 22 februari 2010 in de Amsterdamse Stadsschouwburg met veel media-aandacht voor het eerst werd gepresenteerd. Upload Cinema zijn thema-avonden rond YouTube-filmpjes in grote traditionele theater- en filmzalen. ${ }^{106}$ De filmfragmenten worden door het publiek geselecteerd op thema of op likes. Individuen nomineren filmpjes, groepen liefhebbers vinden het de moeite waard om zich naar een verzamelpunt te begeven om ze in gezamenlijkheid te bekijken, een filmzaal als die van de Verkadefabriek maakt dit fysieke treffen van gelijkgestemde geesten mogelijk en faciliteert tevens een ontmoeting tussen hen en andersgestemden of een kennismaking met ander podiumaanbod.

\section{Woord}

Regelmatig worden in de Verkadefabriek publieke debatten of stadsdebatten geprogrammeerd op momenten dat de actualiteit daarom vraagt, bijvoorbeeld in de aanloop naar of tijdens verkiezingen, maar ook in periodieke programma's als Nieuwscafé, Avondeditie, Kunstdienst, milieucafé MiNC en het Bosch Architectuur Initiatief. Deze programmacategorie wordt door de Verkadefabriek geafficheerd onder het kopje Woord. ${ }^{107}$

\footnotetext{
${ }^{105}$ Ilona van Heeckeren, filmprogrammeur Verkadefabriek, op vrijdag 9 november 2012 telefonisch geconsulteerd over deze categorisering.

${ }^{106}$ Interview met Barbara de Wijn (Metz, 2010) in NRC Handelsblad. Inmiddels is door oprichters Dagan Cohen en Barbara de Wijn een professionele organisatie en redactie geformeerd rond de cinemauploadformule met vestigingen in diverse Nederlandse, Belgische en Spaanse theaters en filmzalen. De Verkadefabriek programmeert iedere twee maanden in dit kader een programma rondom een bepaald thema: 'De webvideo's worden ingezonden door het publiek, geselecteerd door een jury en vervolgens vertoond op een groot scherm...' uit programmabulletin van de Verkadefabriek april 2012. pp.11. Een paar jaar later, in de Volkskrant van vrijdag 22 juni 2012, kondigde Dragan Cohen aan dat de Nederlandse omroeporganisatie VPRO in het voorjaar van 2013 ging starten met een Upload Cinema televisieprogramma als een interactieve liveshow, Upload TV geheten. Het programma is inmiddels vanaf april 2013 een aantal malen uitgezonden en de reacties op de eerste uitzendingen waren wisselend. Het werd door vooral veel jongeren gewaardeerd maar men was tevens kritisch over de presentatie door Dagan Cohen en Gwen Pol. Retrieved 04-28-2014, from http://uploadcinema.net/

${ }^{107}$ De Verkadefabriek hanteert de programmacategorieën: Theater, Dans, Cabaret, Kinderkunstfabriek, Film, Woord, Muziek, PuurDansen en Eten en Drinken.
} 
De Avondeditie is de maandelijkse live talkshow in samenwerking met de regionale krant het Brabants Dagblad. De presentatie is in handen van de journalisten Jan Tromp en Theo van de Zande. De talkshow heeft een vaste redactie die zorgdraagt voor een programma met een gesproken column, muzikale intermezzi en elke maand drie gasten uit het hart van de actualiteit. De afgelopen jaren waren onder anderen te gast: Bas Haring, Theo Maassen, Freek de Jonge, Els Swaab, Frits Bolkestein, Jolande Sap, Erwin Olaf, Guusje ter Horst, Ronald Plasterk, Dries van Agt, Antoine Bodar, Ramsey Nasr en Midas Dekkers. De publieke belangstelling is groot, maandelijks zitten er rond de tweehonderd toeschouwers in de grote zaal.

Dinsdag 13 maart 2012, praatprogramma de Avondeditie. Gasten in de grote zaal van de Verkadefabriek zijn artistiek leider en regisseur bij Toneelgroep Amsterdam Ivo van Hove, PvdA-kamerlid Jeroen de Lange, popmuzikant Anneke van Giersbergen en directeur van het Sociaal Cultureel Planbureau Paul Schnabel. Gastheren zijn Jan Tromp en Theo van de Zande, waarbij Van de Zande de gespreksleider is en Tromp de provocateur speelt. De zaal zit nagenoeg vol, het publiek is over het algemeen boven de veertig en lijkt hoger opgeleid. Op het podium zitten de gasten aan een ronde tafel met daarop flessen water en een paar iPads, ze hebben allemaal plakmicrofoontjes. Het podium is verfraaid met zeer grote palmplanten en er staat een vleugel aan de ene kant en spreekgestoelte aan de andere kant. Daar zal later de vaste columnist van de avondeditie, Tony van der Meulen, zijn column uit spreken. Er worden soms op een groot achterdoek korte filmpjes geprojecteerd ter illustratie van wat in het gesprek aan de orde is. Ik hoor om me heen mensen tegen elkaar spreken: 'Ik kom voor Anneke', 'Ik kom voor Schnabel'. Stipt om 20.00 uur klinkt een muziekje en introduceert een voiceover de gespreksleider en de gasten: Van Hove had ondanks de bezuinigingen een topjaar; Anneke van Giersbergen, bekend als heftige popmuziekdame, maakte de muziek en de liedteksten voor de kindervoorstelling De beer die geen beer was; ${ }^{108}$ Jeroen de Lange, net terug van een jarenlang verblijf in Oeganda als diplomaat, is nieuw als lid van de Tweede Kamer voor de PvdA; Paul Schnabel relativeert de somberheid en gedeprimeerdheid van veel Nederlanders met feiten die de andere kant op lijken te wijzen. Na ieder uur ongeveer speelt Van Giersbergen een gevoelig lied op de vleugel. Voorts is haar bijdrage aan het geheel dat ze verklaart absoluut geen concessies te willen doen, dat ze voor 'puur' gaat, of dat nu in een rocksong is of in een kinderlied. Het gesprek van de avond wordt ingezet met een vraag van Van de Zande aan de Vlaming Van Hove en aan de lang afwezige De Lange: is er veel veranderd in Nederland sinds Fortuyn werd vermoord? Wat is er aan de hand in het land? Er worden vriendelijke woorden uitgewisseld, de toon is mild. Jan Tromp tracht

\footnotetext{
${ }^{108}$ De beer die geen beer was (2012) is een voorstelling voor kinderen en volwassenen van Productiehuis Oost Nederland i.s.m. Wintertuin en Generale Oost. De voorstelling is gebaseerd op The Bear That Wasn't (1946) van Frank Tashlin.
} 
af en toe een wat fellere voorzet te geven, maar er is geen echt belang om te verdedigen. Men lijkt het eens over de toegenomen grofheid in de samenleving, over de ongewisse tijd die we tegemoet treden onder invloed van aan populariteit winnend populisme in Nederland en over de toegenomen brutaliteit en botheid van de media in het algemeen. Van Hove noemt kunst het 'zuiveringsstation van de samenleving' en voorts schetst hij hoe goed TGA het doet en eindigt met de conclusie dat we het met zijn allen wellicht even niet meer weten en dat de spannende wisselwering tussen individu en samenleving soms even tijd nodig heeft om onder veranderende omstandigheden uit te kristalliseren. Presentator Van de Zande sluit af en na twee en een half uur verlaten we gedisciplineerd de zaal.

\section{Festivals}

De Verkadefabriek is een festivalplek voor 's-Hertogenbosch en verre omgeving: Theaterfestival Boulevard, November Music, Festival Cement voor startende theatermakers, Bosch Art Film, Geen daden maar woorden, Theater aan de Parade, het Dans!code Festival, popodium W2, jongerenfestival B-there en spin-offs van het Internationaal Documentaire Festival Amsterdam en van het Internationaal Filmfestival Rotterdam vormen een bonte verzameling festivals op de jaaragenda van de Verkadefabriek. Elk festival kent zijn eigen publiek met een overlap van culturele omnivoren. Tijdens festivals waar de Verkadefabriek bij betrokken is, worden meestal alle publieksruimtes ingezet. De verschillende stromen festivalpubliek zwermen in en uit het gebouw, mengen in foyers en café-restaurant met reguliere theater-, film- en restaurantbezoekers. De Verkadefabriek is diverse malen per jaar het hoofdpodium van een zelfgeorganiseerd festival, of het podium van een festival dat op meerdere plaatsen in Nederland wordt vormgegeven vanuit een externe organisatie, of is als een van de festivallocaties betrokken bij een breder cultureel stadsfestival. Een van die festivals, geïnitieerd vanuit een externe organisatie, is het in mei 2010 voor de vijfde maal georganiseerde literaire festival Geen Daden Maar Woorden. ${ }^{109}$

Zaterdag 15 mei 2010, 20.00 uur. Bij binnenkomst krijg ik een polsbandje zodat ik me vrij kan bewegen. Het festival wordt geopend in de grote zaal, het is afgeladen vol. Het podium staat vol met microfoons, muziekinstrumenten en andere benodigdheden voor live optredens. Er wordt afgetrapt door Roospolder, een gelegenheidsduo van

\footnotetext{
${ }^{109}$ Festivalorganisatie Passionate Bulkboek, Rotterdam: 'Geen Daden Maar Woorden Festival is een festival dat ieder jaar in oktober in Rotterdam en Utrecht en in mei in 's-Hertogenbosch plaatsvindt. Het festival presenteert literatuur in combinatie met muziek, film, dans en theater. Het resultaat is een festival op de scheidslijn tussen kunst en uitgaan. De organisatie onderhoudt contacten met het reguliere onderwijs, geeft een magazine uit en organiseert vaksymposia op het gebied van literatuur en literatuuronderwijs. Retrieved December 28, 2012, from www.gdmw.nl
} 
twee jonge vrouwen, bestaande uit de Bossche cabaretière Katinka Polderman en popzangeres Roos Rebergen. De laatste geniet enige landelijke bekendheid met haar band Roosbeef. Vrolijke liedjes, kritisch, ironisch; 'lichtvoetig cynisme', zegt het programmablaadje. In deze grote zaal volgt het voorlezen uit eigen werk door Tom Lanoye en Ronald Giphart, later zullen ze voor liefhebbers in de hal bij de boekenstands hun boeken signeren. De iets mindere literaire goden Robert Vuijsje en Ivo Victoria treden op in de kleine zaal. In de grote zaal is het festivalpubliek een mix van oud en jong met een duidelijke meerderheid voor de wat oudere, middelbare literatuurliefhebber. In de andere, kleinere zalen, waar pophelden literair werk vertolken, is de verhouding precies andersom. Daar zitten meer jongeren, die afkomen op hun helden die in opdracht van het festival een gedicht van een Nederlandse schrijver hebben bewerkt tot een popsong of ballade. Zo vertolken onder de festivaltitel Poetracks de popmuzikanten Solo, Maurits Westerik (GEM) en Roos Rebergen gedichten van grote Nederlandse dichters; teksten van Remco Campert, Hugo Claus, Harry Mulisch en Gerard Reve passeren de revue. ${ }^{110}$

In de drukte van zaaltje naar zaaltje slenterend, ontdek ik dat er ook nog steeds in een paar zalen gewoon films vertoond worden. Dat publiek mengt zich met het festivalpubliek in de gangen en in het drukke café-restaurant. Alle zalen en zaaltjes die ik bezoek, zijn nagenoeg volledig gevuld met publiek als de voorstellingen of voordrachten beginnen, de meeste activiteiten laten het toe dat het publiek vrijelijk in en uit loopt. In de gangen worden op marktkraampjes literaire tijdschriften, boeken, vintage sieraden en damestasjes verkocht. Wat voorts opvalt, is dat nagenoeg bij elk soort van optreden gebruik gemaakt wordt van bewegend beeld, foto's of projecties van teksten.

Op een dergelijk festival zou je kunnen zeggen dat er sprake is van schakelmomenten tussen verschillende publieksgroepen en verschillende cultuurbelevingen. Het podium doet iets met de optredende auteurs en artiesten, en andersom. Door zo'n festival mede mogelijk te maken doet de Verkadefabriek iets met een bekende Nederlandse auteur als Harry Mulisch, met popzangeres Roos Rebergen en met de geprojecteerde beelden en de geproduceerde geluiden die ze samen gebruiken. Alle performers die optreden, fysiek zowel als virtueel, genereren in combinatie met de Verkadefabriek betekenis en andersom genereert de Verkadefabriek met de verschillende groepen publiek in hun samenhang betekenis en schakelt die weer terug naar de optredende gasten. De performers geven het gebouw een zweem mee van serieuze en reflectieve cultuurbeleving en zij worden op hun beurt weer geassocieerd met waar de Verkadefabriek voor staat.

\footnotetext{
${ }^{110}$ GEM is een rockband uit Utrecht.
} 
De aanwezigheid van cultuurwethouder Weterings en publicist en journalist Jan Tromp dragen bij aan het gewicht van het festival en van de Verkadefabriek door actief en betrokken aanwezig te zijn, men kent ze en ze zijn aanspreekbaar. Ze geven betekenis aan het gebouw en aan de gebeurtenis door er publiekelijk op te treden in de vorm van live uitgesproken columns zoals zij die tijdens het literaire festival verzorgden of door deel te nemen aan een publiek debat in het kader van de verkiezingen of anderszins. Ze vinden het blijkbaar zinvol om daar te zijn, om zich daar regelmatig te profileren ten overstaan van verschillende soorten gemengd publiek. Dit publiek weet dat het deze bestuurders en andere publieke figuren kan treffen bij diverse gelegenheden. Nu, tijdens Geen Daden maar Woorden, luistert men staande in een foyer aandachtig naar wat deze mannen te zeggen hebben over de toekomst van het culturele leven in een provinciestad als 's-Hertogenbosch, vlak na de betekeniszwangere Nederlandse gemeenteraadsverkiezingen van het voorjaar van 2010 en vlak vóór de landelijke Tweede Kamerverkiezingen die daar in het najaar op volgden met de grote verkiezingsoverwinning van de PVV (Partij Voor de Vrijheid) en de totstandkoming van het gedoogkabinet-Rutte. Het volgende moment gaat het publiek weer op in een song van Maurits Westerik. De officiële, formele wereld van politici, bestuurders en journalisten laat zich in met de literaire wereld, die zich op haar beurt weer inlaat met popmuziek en met het publiek voor die muziek. Het geheel van dit alles verhoudt zich tot een gebouw waarin deze zaken zich voegen naar een vooraf bedacht programmaformat in combinatie met een café-restaurant, met een paar normaal functionerende filmzalen in hetzelfde gebouw en met een aanbod in de rest van de stad. Het publiek op het festival is niet helemaal autochtoon maar wel overwegend. Dat verandert na middernacht, als er als onderdeel van het festival een afterparty plaatsvindt onder leiding van deejay Pathless. Groepjes jonge mensen, onder wie een substantieel deel met niet-westerse roots, bewegen zich dan op de dansvloer en flaneren door de gangen naar binnen en naar buiten. Buiten staan diverse groepjes jongeren met elkaar te praten, te lachen en te roken. Alles na middernacht ziet eruit, klinkt en ruikt als uitgaan. Op dergelijke momenten is de Verkadefabriek een kruispunt, een centrum waar geschakeld wordt tussen filmliefhebbers, literatuurkenners, popmuziekconsumenten en popmuzikanten, tussen hoog- en laagopgeleiden, tussen politiek geïnteresseerden en publiek dat komt voor een maaltijd of om te dansen. Men heeft meer of minder met elkaar, men spreekt elkaar wellicht maar niet per definitie, men weet dat men elkaar kan treffen en het gebeurt allemaal onder één dak.

Dit schakelen, dit contact maken en weer loslaten, kan in de Verkadefabriek op 363 dagen per jaar. ${ }^{111}$ Op festivals wordt geschakeld maar ook tijdens programma's als de

\footnotetext{
${ }^{111}$ Eerste Kerstdag en de dag van het jaarlijkse uitstapje van medewerkers zijn de enige twee dagen per jaar dat de Verkadefabriek dicht is.
} 
Avondeditie gebeurde het, tussen het specifieke gebouw en politieke voorkeuren, tussen wetenschap (Schnabel), popmuziek (Van Giersbergen), politiek (De Lange), theater (Van Hove), een plaatselijke krant (Brabants Dagblad) en het publiek. De meervoudige relatie tussen wat deze Avondeditie programmatisch bracht, de plaats waar dat gebeurde inclusief de andere activiteiten op dezelfde avond onder één dak en de bijbehorende publieksegmenten, is een andere dan die tussen publiek en optredende theaterkunstenaars in wat een podiumgebouw van de gesubsidieerde infrastructuur aanvankelijk was, een enkelvoudige schakel tussen canonieke podiumkunstenaars en een te verheffen publiek. Hetzelfde geldt voor het mogelijk terloops schakelen tussen gebouw, café-restaurant, amateurtheater, filmpubliek en commerciële huurders; er bestaat een beoogde mogelijkheid tot onderlinge 'besmetting'.

\section{Bedrijfsvoering}

De keuze van de Verkadefabriek bij haar start om een eigentijdse ontmoetingsplek te faciliteren met een eigen marketingconcept getuigde van een eigenzinnige omgang met haar podiumfunctie in het theatersysteem. ${ }^{112}$ Vanaf het eind van de jaren zeventig dragen de lokale overheden (gemeenten) de verantwoordelijkheid voor de podia, wat in de meeste gevallen neerkomt op een substantiële subsidieverantwoordelijkheid. Beleid van podia wordt dan ook in de regel in sterke mate medebepaald door cultuurbeleidsmissiven van de lokale overheid. In deze wederkerige afhankelijkheid heeft de Verkadefabriek het afgelopen decennium bewust gezocht naar steeds grotere autonomie op basis van een analyse van het eigen functioneren. Deze visie en het handelingsperspectief van de koersbepalers van de Verkadefabriek is af te lezen uit de jaarlijkse bedrijfsplannen. Directie, raad van commissarissen, stafleden en personeel problematiseren het eigen functioneren in een als publiek domein opgevatte podiumorganisatie. Men gaat daarbij niet uit van voor de eeuwigheid vastliggende vanzelfsprekendheden, wel van het verankeren van engagement zowel in het programmeren van theater, entertainment en film als waar mogelijk in de bedrijfsvoering. Jaarlijks vraagt men zich bij de Verkadefabriek af wat haar rol is, zou kunnen zijn of gaat worden in de stad 's-Hertogenbosch en in de regio. In periodiek georganiseerde overlegstructuren en strategiebijeenkomsten reflecteert men op de positie van de organisatie in een veranderende culturele, maatschappelijke en politieke context.

In het bedrijfsplan van 2010 werd geconcludeerd dat de kunsten zich in de afgelopen jaren meer en meer zijn gaan mengen met uitgaan, mode, reclames en life

\footnotetext{
${ }^{112}$ Zie de uitspraak van Rodney Weterings en zijn verwijzing naar Paul Schnabel in het begin van paragraaf 4.2.
} 
style, met communicatiestrategieën en met low culture-uitingen. Men concludeerde dat jongerencultuur niet ophoudt na het twintigste levensjaar, maar een leven lang geconsumeerd lijkt te worden en dat er na de jonge jaren geen automatische wending van het publiek plaatsvindt naar traditionele cultuurbeleving (Verkadefabriek, 2010, p. 6). De vraag die daar in de Verkadefabriek bij hoort is: wat betekent dat voor ons functioneren in de openbare ruimte? Alle gespecialiseerde podia zagen door deze verschijnselen een graduele afname van publiek voor gesubsidieerde kunst, speciaal van publiek voor de traditionele podiumkunsten. Ook in de Verkadefabriek constateerde directeur Jan van der Putten gaandeweg manifeste problemen met de programmering van gesubsidieerd theater. Hij vond dat er fundamenteler nagedacht zou mogen worden over het functioneren als podium daarvoor.

JVDP: Wat er met name wringt met die theaterprogrammering is, dat als je het hebt over bildung, dan heb je het over publiek. Hoewel wij onze theaterfunctie impliciet of expliciet altijd sterk hebben ingevuld vanuit een soort verantwoordelijkheid voor het bestel, of voor een productieklimaat waar publiek bij gezocht moest worden, dat is heel cruciaal. Maar de vraag is of die twee dingen [verantwoordelijkheid voor het culturele klimaat tout court en cultuur met publiekelijk draagvlak HH] nog wel parallel lopen. Sterker nog, ik denk dat ze niet meer parallel lopen, snap je. (...) Kijk, want jij hebt het over gesubsidieerd theater als laboratorium, dat klopt, denk ik. Maar als je het over een bildungsideal hebt dan heb je het uiteindelijk over resultaten uit het laboratorium die als toepassingen voor het publiek geschikt gemaakt zijn. Er zijn heel veel mensen in het laboratorium aan de slag en er zijn er maar heel weinig die na het laboratoriumwerk de resultaten geschikt maken voor het grote publiek, daar zit frictie. (...) En subsidiesystemen zijn daar dan weer de vertaling van. Je kunt ofwel zeggen, ik wil dat het publiek deze dingen kan meemaken. Of je kunt zeggen, nee, dat is niet richtinggevend, ik wil juist dat deze en deze theatermakers zich verder kunnen ontwikkelen en daar zoek ik dan publiek bij. De kern van onze interne discussie is de keuze voor een groter publiek of de keuze voor talentontwikkeling en laboratorium. En we schuiven nu op naar de publiekskant. Daar gaan we wat meer naar toe, maar je hebt daar veel weerstand in te overwinnen, ook van de mensen in dit pand natuurlijk.

$\mathrm{HH}$ : Ja, natuurlijk, dat zijn artistieke passies, dat zijn banen, dat zijn ambities.

JVDP: Ja, maar ik denk ook niet dat 't het een of het ander hoeft te zijn, die research-and-development-afdeling moet er wel zijn, maar ik zie dat we teveel van het een doen en te weinig van het ander. ${ }^{113}$

\footnotetext{
${ }^{113}$ Uit de transcriptie van het interview met Jan van der Putten op 9 september 2008 te 's-Hertogenbosch. [digitaal audio bestand] (timer A-29.55/transcriptie H.Havens).
} 
Vanaf 2010 hebben zich majeure bewegingen voltrokken in de Nederlandse politieke verhoudingen, die hun uitwerking op het functioneren van culturele instituties niet hebben gemist. De reactie van de Verkadefabriek op verminderde overheidssteun bevat de volgende hoofdlijnen: het streven naar 75 procent eigen inkomsten; het streven naar een groter eigenaarschap van het gebouw om nog onafhankelijker te worden van de overheid; verregaande afspraken voor wat betreft de programmering met andere theaters in 's-Hertogenbosch; na januari 2013 structurele afspraken met regionale verantwoordelijken voor talentontwikkeling, te weten Het Zuidelijk Toneel, het onttakelde Productiehuis Brabant en Theaterfestival Boulevard; een nieuwe tak voor de podiumprogrammering in de vorm van een samenwerking met het gespecialiseerde cabaretpodium van het Bossche Koningstheater.

Uit het bedrijfsplan voor 2012: 'Meer dan ooit vragen ontwikkelingen "van buiten" om reflectie op onze functie in het publieke domein en de manier waarop we die ook in de toekomst kunnen blijven vervullen (Verkadefabriek, 2012, p. 3).' De Verkadefabriek was de afgelopen jaren voor ongeveer 60 procent selfsupporting geweest en 40 procent van de financiering kwam direct van de gemeente of indirect van het Rijk via de gesubsidieerde huurders. De directie is in 2012 realistisch genoeg om te zien dat het aanbod van het gesubsidieerde theater de komende jaren zal verschralen. De zelfreflectie over het opvangen hiervan steunt op twee geconstateerde invloeden: de houding van de overheid ten opzichte van de kunsten en snel veranderend publieksgedrag.

Over de overheid wordt geconcludeerd dat die zich steeds minder automatisch opstelt als hoeder van de kunsten. De beeldvorming is volgens de schrijvers van het jaarverslag verschoven van kunst als essentieel onderdeel van de samenleving naar iets wat met achterdocht bekeken dient te worden. Het ziet er volgens hen naar uit dat het aanbod van theater en dans drastisch zal afnemen, bovendien zal het publiek voor de podiumkunsten afnemen als gevolg van een onvermijdelijk lijkende kostenverhoging. Al met al wordt een imagoprobleem voor de kunsten gesignaleerd. Voor wat betreft het snel veranderende publieksgedrag wordt in het Bedrijfsplan 2012 geciteerd uit Koers Kunst, een brainstorminitiatief van het Amsterdamse adviesbureau LA group als reactie op de overheidsbezuinigingen vanaf 2010 op kunst en cultuur. Johan Idema en Simon van den Berg van LA group:

'Kunst en cultuur zijn in een stroomversnelling terechtgekomen van globalisering, commercialisering, democratisering en digitalisering. De komende tien jaar veranderen deze megatrends rigoureus hoe kunst en cultuur - van theater tot televisie, van film tot boeken, van mode tot monumenten- worden gemaakt, geconsumeerd en gewaardeerd. De cultuurwereld zal, soms radicaal, mee 
moeten veranderen, wil zij een kans maken in de concurrentiestrijd met andere vrijetijdsaanbieders' (Verkadefabriek, 2012, p. 3).

Men vraagt zich in de Verkadefabriek structureel af hoe zich te verhouden tot de relatief nieuwe soorten verhalenvertellers, musici, deejays en andere performers in de grensgebieden tussen professionele kunstenaars, entertainers, amateurs en hun respectievelijke publiek. Anno 2015 is een steeds grotere rol weggelegd voor digitale en multimediale toepassingen als Facebook, Vimeo, Instagram, Twitter, weblogs en andere kanalen, zoals ook in toenemende mate wordt onderkend in de Verkadefabriek. In de beleidsdocumenten wordt dat beschouwd als een belangrijk verschijnsel waar men zich als publiek podium toe te verhouden heeft en dan niet alleen marketingtechnisch. Als een theaterpodium een website inzet als marketinginstrument is dat van een andere orde dan doorlopend fundamenteel nadenken over nieuw in te nemen posities als publiek podium, als schakelcentrum in een gemediatiseerde, interculturele en globaliserende wereld.

\subsection{De Verkadefabriek als mediator}

In het gevestigde theatersysteem zijn podia schakels in de vaste keten van gezelschapproductie-podium. ${ }^{114}$ We kunnen op basis van de empirie constateren dat naast deze traditionele theaterpodia zich nu podia ontwikkelen als de Verkadefabriek die een andere positie kiezen. Culturele dynamiek manifesteert zich in het feit dat zij kiezen voor een positie als dynamisch meerduidig schakelcentrum in plaats van die als schakel in een lineaire theaterproductieketen. In en rond een podiumgebouw als de Verkadefabriek kunnen diverse culturele publieksgroepen en producenten elkaar ontmoeten in de functie van besmetten, in de positieve betekenis van het woord. In een schakelcentrum is er een actieve rol weggelegd voor individuele bezoekers zowel als voor publieksgroepen; ze zijn impliciet actief in een intercultureel uitwisselingsproces tussen groepen, door voor verschillende soorten ervaring naar één plek te komen en elkaar daar hoe dan ook tegen te komen. De uitvoerenden zijn zo niet de enige actieven, toeschouwers worden impliciet coproducenten.

Op de weg naar het ontstaan van deze schakelcentra zijn er al eerder pogingen geweest om de traditionele schakelfunctie van podia te doorbreken, bijvoorbeeld met een genre als locatietheater of met een schouwburgprogrammering als Expanding Theatre, maar dat is niet hetzelfde als een podium dat zich structureel opstelt als schakelcentrum. Hierna zal ik allereerst ingaan op deze pogingen en op het verschil daarvan met podia als schakelcentra, vervolgens analyseer ik met behulp van de Latours ANT de werking van de Verkadefabriek als mediator en daarna bespreek ik

\footnotetext{
${ }^{114}$ Zie ook Hoofdstuk 1.
} 
enkele kwesties die de positie van traditionele podia betreffen ten opzichte van die van podia als de Verkadefabriek.

\section{Kruispunten van het inter}

Het formele karakter van de oorspronkelijk negentiende-eeuwse burgerlijke traditie van theatervoorstellingen is in de meeste schouwburgen min of meer overeind gebleven. Deze door sommigen als deftig beleefde sfeer hoorde bij een vooral door de middenklasse gekoesterde hogere cultuurbeleving van canonieke podiumkunst en theater. Terwijl er in de nieuwe schouwburgen na de Tweede Wereldoorlog een zekere burgerlijke chique werd nagestreefd bij de keuze van de bouwmaterialen, vloerbedekking, meubilair, verlichting, horecafaciliteiten en ongeschreven kledingvoorschriften, heeft deze sfeer in Nederland nu vaak alleen nog iets te maken met specifieke activiteiten die er plaatsvinden, eerder dan met de functies van het gebouw als zodanig. Hierbij ziet men publiek dat zich bijvoorbeeld speciaal kleedt voor gebeurtenissen als de uitreiking van landelijke of lokale cultuurprijzen, bij de landelijke première van een nieuwe musical of bij de opvoering van een opera. Voor bezoek aan het reguliere hedendaagse Nederlandse theater, voor een lokaal carnavalsfeest of voor een willekeurig congres hebben schouwburgbezoekers hun chique ingeleverd, al blijft de relatie tussen uitvoerende kunstenaars en publiek in de meeste schouwburgen nog traditioneel formeel te noemen.

In het verleden is er op diverse manieren geprobeerd dit klassieke patroon te doorbreken in het kader van verheffingsstrategieën. Kunstenaars, de overheid en brancheorganisaties hebben getracht te schakelen tussen een krimpend traditioneel publiek en een potentieel nieuw publiek, tussen verschillende concepten van publieksbenadering en podiumgebruik. In de meeste gevallen leverde dat pogingen op om nieuw publiek te werven voor traditionele theatervormen. Een goed voorbeeld hiervan is het in de jaren tachtig en negentig groot geworden locatietheater. De toon werd toentertijd gezet door Theatergroep Hollandia onder leiding van Johan Simons en Paul Koek. Simons legt anno 2013 als gevierd theaterregisseur in Duitsland nog graag publiekelijk uit hoe hij in eerdere periodes van zijn carrière in Nederland experimenteerde met locatietheater om theater te brengen naar plaatsen waar geen theater was. Hij wilde destijds koste wat het kost weg van het pluche. Het gevolg was, volgens zijn eigen zeggen maar ook gebaseerd op publieksonderzoek, dat op den duur de deftige burgerlijke elite uit de centra van de grote Nederlandse steden maar al te graag afreisde naar de afgelegen industriële en agrarische speelplekken die hij en zijn gezelschap hadden uitgekozen om er 'belangrijk theater' te zien van toonaangevende regisseurs. Op dergelijke momenten veranderde weliswaar de plaats waar theater gespeeld werd, maar nauwelijks het publiek dat ermee bediend werd. 
Vergelijkbare pogingen om de traditionele schakelfunctie van het podium te doorbreken zijn ondernomen in de Amsterdamse Stadsschouwburg door directeur Melle Daamen. In een programma dat hij Expanding Theatre noemde en dat hij bij zijn aantreden in 2001 in de beleidsnota De Schouwburg ontsloten onderbouwde, programmeerde hij in de loop der jaren een reeks politieke debatten, alternatieve sinterklaasfeesten, designcongressen, talkshows, dansfeesten, prijsuitreikingen, $Q$ \& $A^{\prime}$ $s$ met internationale kunstenaars en andere niet-reguliere podiumgebeurtenissen. Hij gebruikte daarbij het gehele statige gebouw aan het Leidseplein (Daamen \& Meijler, 2012). Het verschil tussen dit innovatief gebruik van een traditioneel podium en dat van emerging podia is dat het bij programma's als Expanding Theatre gaat om incidentele gebeurtenissen in een bedding van traditioneel gebruik en in een deftig gebouw in het centrum van de hoofdstad, met alle symbolische lading die dat kan hebben. Bij hybride podia als de Verkadefabriek is het denkbaar dat er traditioneel of experimenteel theater geprogrammeerd wordt of dat er anderszins aandacht is voor gevestigde cultuur, maar daar is het embedded in een veelheid van heterogene cultuuruitingen, bovendien niet in een gebouw met een dominant deftige uitstraling. In de situatie van het traditionele podium dat incidenteel innovatief experimenteert is het andere omgeven door het gevestigde traditionele. In de situatie waarin het hybride podium traditioneel programmeert, is het traditionele omgeven door de anderen en het andere.

Podia die we aldus op kunnen vatten als schakelcentra, bevinden zich op kruispunten van het inter. We kunnen zeggen dat er bij hedendaagse cultuurbeleving modulair en veelal tijdelijk geschakeld wordt tussen interculturele, intermediale en internationale culturele groeperingen, cultuuruitingen, opvattingen en smaken. Dit gebeurt zowel op fysieke plaatsen waar uitvoerende kunstenaars een direct contact hebben met hun publiek als ook op virtuele podia van socialemediasites, film- en muzieksites, discussiefora op internet en in de gedrukte media (Parker \& Kosofsky Sedgwick, 1995, p. 2). Bij het definiëren van wat podia als schakelcentra zijn, gaat het om meer dan om plaatsen voor verschillende vormen van vermaak, of om verschillende opvattingen over het conserveren van cultureel erfgoed. Het gaat daarbij tevens om plaatsen met een geïntegreerde intermediale, interculturele en internationale schakelpotentie waarmee verschillende wereldbeelden en opvattingen elkaar bewust kunnen raken, 'besmetten' of bevragen. Er wordt op dergelijke plaatsen impliciet gebouwd aan beïnvloeding van het collectief geheugen en aan herijking van in kunst en culturele uitingen verpakte ethische en esthetische codes voor naast en door elkaar bestaande groepen. Het gaat hier om de mogelijkheden voor ontmoeting van '(...) gecoïsoleerde, op een netwerk aangesloten eilanden, die kortstondig of chronisch middelgrote of grote structuren met buureilanden moeten vormen (...)', zoals Sloterdijk deze tijdelijke assemblages beschrijft (Sloterdijk, 2009, p. 423). 
Theaterpodia als stadsschouwburgen en vlakkevloertheaters hebben als voormalige culturele centrumpodia een groot aantal podia als buren gekregen: muziektheaters, danstheaters, fabriekshallen, festivalterreinen, tenten, catwalks, buurthuizen, stadspleinen, scholen, musea, nachtclubs en poptempels, maar ook hybride plaatsen voor vertoning van geënsceneerde gebeurtenissen als televisie, filmzalen en internetsites. Al deze performatieve podia zijn verschillend en ze hebben niet allemaal dezelfde impact, maar ze zijn niet meer te negeren als deel van het domein van het geënsceneerde, van het performatieve (Parker \& Kosofsky Sedgwick, 1995, p. 2).

\section{Transportation en translation}

De transformatie van de Verkadefabriek in Den Bosch speelt zich voornamelijk af onder invloed van interculturele bewegingen. Als schakelcentrum is de Verkadefabriek niet één podium maar vele tegelijk. Latours etnografische ANT-aanpak leent er zich goed voor om dit kruispunt van verschillende werelden te analyseren.

Als filosoof en wetenschapssocioloog beschrijft Latour in de Actor Network Theory (ANT) de werking van wetenschappelijke praktijken en controversen als het smeden van stabiele netwerken van relaties van en tussen betrokken actoren. Alles wat maar op een of andere manier kracht uitoefent of weerstand kan bieden in een bepaalde procesgang, individuen zowel als organisaties en objecten, is te beschouwen als actor. Zo beschouwd zijn bij de Verkadefabriek het podium, de bijbehorende organisatie, de financiers ervan, het publiek dat het bedient, de kunstenaars die er optreden of anderszins werken, het horecapersoneel, de muziekinstallatie en de designmeubelen of de architectuur van het gebouw actoren te noemen in het schakelproces. Tijdens dergelijke processen van netwerkbouw, zegt Latour, wordt meestal de bestaande orde geherdefinieerd. Een innovatief podium als de Verkadefabriek fungeert als mediator tussen heterogene publieksstromen van culturele, sociale en maatschappelijke groepen en netwerken van mensen, hun referentiekaders en opvattingen. "Mediators transform, translate, distort and modify the meaning or the elements they are supposed to carry." (Latour, 2005, p. 39) De publieksgroepen, de ambtenaren of politici die bij bepaalde activiteiten aanwezig zijn, de optredende entertainers of gezelschappen en de films die geprojecteerd worden, allemaal krijgen ze een Verkadefabriek-imago mee en veranderen ze door de bewuste of onbewuste ontmoetingen. Een voorstelling bezoeken als een van de opties in een schakelcentrum als de Verkadefabriek, heeft een andere symbolische lading en kent meerdere potentiële schakelmomenten tussen publieksgroepen en ervaringssettings dan zich zullen voordoen bij een gemiddeld theaterbezoek in een traditionele schouwburg, die 
opereert als intermediair; en "...transports meaning or force without transformation, defining its input is enough to define its output" (Latour, 2005, p. 39).

De verzameling podia van de Verkadefabriek toont dat het gebouw het samengaan van uiteenlopende culturen (interculturaliteit in brede zin) als het ware performt, waarbij de diverse actoren in het proces opereren in een niet-hiërarchisch geordende verhouding tot elkaar. Door deze non-hiërarchische verhoudingen verandert de betekenis en de positie van het geprogrammeerde gesubsidieerd theater, van dans en muziek. Canonieke podiumkunst en gesubsidieerde experimenten verhouden zich rond podia als de Verkadefabriek op een gelijkwaardige manier tot film, debat of uitgaan. Waar in de traditionele situatie sprake was van transportation, van het doorgeven van vastliggende culturele waardes, vinden hier in Latouriaanse zin translations plaats, meer op te vatten als mogelijke betekenisassociaties dan als min of meer voorgeschreven verheffingsidioom. De rol van de traditionele categorieën verandert hierdoor van toonaangevend en dominant naar een positie van subcultuur onder de subculturen, Latour zegt het als volgt:

"So the word 'translation' now takes on a somewhat specialized meaning: a relation that does not transport causality but induces two mediators into coexisting. ... I can now state the aim of this sociology of associations more precisely: there is no society, no social realm, and no social ties, but there exist translations between mediators that may generate traceable associations" (Latour, 2005. p. 108).

\section{Podiumlandschap}

Door de manifeste aanwezigheid van een veelheid aan podiumvarianten wordt de centrumrol van schouwburgen en andere traditionele theaterpodia en hun programmering geproblematiseerd.

In de loop der tijd zijn veel schouwburgen voor een groot deel gaan functioneren als lokale podia met een commerciële programmering in combinatie met de functie van gemeenschapshuis. ${ }^{115}$ Schouwburgexploitanten moeten laveren tussen markt en kunst, tussen exploitatietekorten en algemeen belang (Havens \& Dujardin, 1998). Daarbij spelen verschillen van inzicht over de rol van het gevestigde gesubsidieerde theater. Voor de een is het klassengebonden cultureel vermaak en voor de ander is het noodzakelijke geëngageerde cultuurbeleving. Er vinden belangenafwegingen plaats tussen aan de ene kant conservering van cultureel erfgoed en aan de andere kant het programmeren van het theaterexperiment. De vraag daarbij blijft hoe deze functies houdbaar te definiëren zijn op grond van hun artistieke en culturele betekenis voor de

\footnotetext{
${ }^{115}$ In Hoofdstuk 6 kom ik terug op de rol van de schouwburgen in het Nederlandse theaterbestel.
} 
gemeenschap. Hierbij speelt op de achtergrond het discours over de rol van kunst in het algemeen en die van de podiumkunst in het bijzonder: hoe om te gaan met de relatie tussen het podium als plaats van artistieke openbaarheid en als plaats van morele openbaarheid? Of, zoals cultuurfilosoof Frank Mineur het zich afvroeg: hoe maakt dit theater, dat naast een vrij artistiek ook een vrij moreel podium wil zijn, zich vandaag de dag zichtbaar en ervaarbaar in een veelvoud van plaatsen, opvattingen en visies? Wat voor soort plaatsen dienen nog een publieke zaak in een geïndividualiseerde samenleving en is er nog wel sprake van centrale ontmoetingsplaatsen als knooppunten van debat? ${ }^{116}$ Die knooppunten in de vorm van artistieke en morele podia zijn niet meer per definitie te vinden in sectoren als het gevestigde theater, maar hebben zich steeds vaker ook gevormd rond podia als die van de popcultuur, op catwalks, op festivals of via digitale media. Geen van deze heterogene hedendaagse performatieve podia kan bogen op een min of meer universeel geldende en geïnstitutionaliseerde, gezaghebbende positie zoals schouwburgen die eens hadden. In feite zien we hier een verschuiving van de boomgestructureerdheid van voormalige centrale culturele ontmoetingsplaatsen naar de rizoomgestructureerdheid zonder centrum van de verzameling heterogene podia. Door de een wordt dit ontbreken van een centrum als een probleem of zelfs als een groot gevaar ervaren, door de ander wordt het juist gezien als een van de belangrijkste verdiensten van een innovatieve, dynamische en de hiërarchie ontkrachtende vernetwerking, kenmerkend voor de huidige tijdgeest (Sloterdijk, 2009, p. 423).

Nieuwe podiumvarianten zijn tot het moment waarop ze opduiken in het openbare leven, onzichtbaar geweest voor de officiële canonieke theatercultuur, haar pleitbezorgers en haar publiek. Ze bevonden zich als het ware in nog gesloten vouwen op de achtergrond van de officiële gevestigde cultuur. Ze treden echter steeds vaker voor het voetlicht, ze krijgen vaker serieuze aandacht op de cultuurpagina's, zijn object van onderzoek voor academici en sommige worden stap voor stap geformaliseerd door toekenning van subsidies. Met deze bewegingen worden dergelijke voorheen voor het gevestigde theater min of meer onzichtbare podiumvarianten, met een uitdrukking van Peter Sloterdijk, geëxpliciteerd. ${ }^{117}$ Terwijl veel gevestigde theaterpodia

\footnotetext{
${ }^{116}$ Mineur, F. (2007). Uit: 'De enscenering van de werkelijkheid/de werkelijkheid van de enscenering'. Lezing uitgesproken op het symposium Kunst en Openbaarheid op 5 en 6 oktober 2007 te Utrecht. Het symposium werd georganiseerd door het Nederlands Genootschap voor Esthetica in samenwerking met het Departement Media- en Cultuurwetenschappen en het Onderzoeksinstituut voor Geschiedenis en Cultuur van de Universiteit Utrecht.

117 'De zichtbaarheid van de echte innovatie is altijd het gevolg van explicitatie, wat vervolgens als een 'revolutie' wordt uitgekreten is doorgaans niet meer dan het rumoer dat ontstaat als de gebeurtenis zelf al voorbij is. Onze tijd zet de dingen, de toestanden, de thema's niet op hun kop, hij walst ze uit. Hij ontvouwt ze, hij haalt ze naar voren, hij spreidt ze uit in het platte vlak, hij dwingt ze om zich te manifesteren, hij rafelt ze uiteen en incorporeert ze in synthetische routines. (...) Hij wil alles weten over wat zich op de achtergrond
} 
in 2015 functioneren als lokaal gemeenschapshuis en daarbij het programmeren van gesubsidieerd theater steeds meer als een probleem ervaren, dwingen hybride podia als de Verkadefabriek posities af als schakelcentra in het cultureel dynamische publieke domein. In het najaar van 2009 schrijft filosoof en communicatiewetenschapper Valerie Frissen:

'Digitale media geven culturele en creatieve expressie een ander gezicht, zetten klassieke verhoudingen tussen spelers op zijn kop en dwingen nieuwe manieren van werken af, aldus de Raad [Raad voor Cultuur HH]. Dit betekent dat de culturele sector zichzelf in zekere zin opnieuw moet uitvinden. (...) De inhoud van de culturele schatkist verlaat de voorname gebouwen van de Hoge Cultuur en wordt steeds meer toegankelijk voor een breder publiek. (...) Met de opkomst van de geëmancipeerde gebruiker brokkelt de autoriteit en legitimiteit van de klassieke cultuuraanbieders af ' (Frissen, 2009).

Al in 2002 stelde ook de Vlaamse programmeur en publicist Dirk De Wit zich over de veranderende rol van traditionele podia de volgende vragen:

'Hoe situeert het theater zich als specifieke plaats en als specifiek moment van concentratie in de veelheid van plaatsen die we vandaag de dag doorkruisen en die telkens een specifiek programma, specifieke informatie en ervaring aanbieden; zowel fysieke als virtuele plaatsen, zoals de huiskamer, straten, televisie, media, reclame, bioscoop, computer? Al deze plaatsen tonen zichzelf, zijn perfect leesbaar in wat ze van ons verwachten en wat ze ons beloven. Hoe gaat het theater om met deze ketting van beelden, teksten, ervaringen en informatie? Welke plek neemt het theater in nu de traditionele tegenstellingen tussen binnen en buiten, tussen (gemeenschappelijke) ruimtes van concentratie en publieke ruimte grondig zijn veranderd?' (De Wit, 2002, p. 28).

Bij deze veranderende rol van podia hangt veel af van de positie die een gemeenschap zowel de traditionele als de hybride podia toedicht. Een podium heeft altijd een bij dat podium horende uitstraling en uitwerking, zowel op het publiek dat het bedient als op het publiek dat er om wat voor reden dan ook het liefst wegblijft, alsook op de financiers van dat podium, op overheden die het faciliteren. Diverse bevolkingsgroepen kiezen eigen podiumkunstenaars met bijbehorende podia. Het publiek laat zich weinig meer gelegen liggen aan één universele centrale theatercanon. 
Directeur van het Sociaal Cultureel Planbureau (SCP) Paul Schnabel legt in 2009 in een periodiek onderzoeksverslag van het SCP uit dat het bevoogden van de bevolking door een elite vanuit het aloude bildungsideal in de achterliggende decennia langzaam maar zeker ophield te bestaan. Hij zegt het als volgt:

'De elite aan de top van iedere groep werd in de twintigste eeuw zeker na de invoering van het algemeen kiesrecht een 'planvolvoerende' elite, die het beste voorhad met de eigen groep en ook beter dan de groep zelf wist wat goed voor haar was. (...) Tot een halve eeuw geleden, toen door de verbreding van de welvaart, de verbreiding van de televisie en de verhoging van het opleidingsniveau van de bevolking de samenhang en de eenheid per groep geleidelijk verloren begon te gaan. De elite raakte daardoor los van het 'volk', dat zich steeds meer en beter bediend zag door media en organisaties die niet meer een stem namens het volk waren, maar hun aanbod afstemden op de wensen van het volk. (...) In zekere zin kan men ook in deze situaties van 'emancipatie' spreken, maar dan wel in de zin van een emancipatie uit de sfeer van paternalisme en zelfs bevoogding. Het is de emancipatie van wie weigert zich te laten verheffen tot een door een elite bepaald niveau' (Schnabel, 2009, pp. 1213).

In de programmafolder van de Verkadefabriek voor het seizoen 2012-2013 worden de dames Reiziger (culinair recensenten van het Algemeen Dagblad) geciteerd: 'Waarom heeft niet iedere stad een Verkadefabriek? ' Dat is in dit verband een interessante vraag. Het antwoord kan zijn dat overheden en financiers bij hun keuze om al dan niet te investeren in een podium zich niet door dezelfde motieven laten leiden als die op grond waarvan het publiek ervoor kiest een podium te bezoeken of er weg te blijven, wat de hierna volgende ontwikkelingen in de podiumsituatie van Nederland in het algemeen en Den Bosch in het bijzonder illustreren.

Ondanks de rondzingende crisisgedachte wordt in het begin van de 21 e eeuw in Nederland doorgebouwd aan diverse podia, meestal met overheidssubsidies via de gemeentefondsen. In 2014 deed het NRC Handelsblad een reeks journalistieke onderzoeken naar de overlevingskracht van de culturele sector na de bezuinigingen tussen 2011 en 2013. Een van die onderzoeken betrof een inventarisatie van theaterbouw- en verbouwactiviteiten. Sinds 1990 is er in Nederland voor 1,2 miljard euro geïnvesteerd in grote renovaties en verbouwingen van 70 theaters en concertzalen en 46 van de 140 theaters die Nederland rijk is, hebben nog bouw- en 
renovatieplannen (Kammer \& Van Lent, 2014). ${ }^{118}$ In 's-Hertogenbosch sprak de gemeenteraad zich in april $\mathbf{2 0 1 2}$ met grote meerderheid uit voor een nieuw te bouwen stadsschouwburg. De geraamde bouw- en onderhoudskosten bedragen tussen de 60 en de 70 miljoen euro exclusief de nog te beramen exploitatiekosten. Het gaat hier om een als zodanig herkenbaar theatergebouw met een grote zaal van 1100 stoelen en met een middenzaal van 500 stoelen, beide voorzien van de meest uitgebreide toneeltechnische voorzieningen inclusief toneeltorens. Met de blik op het functioneren van de Verkadefabriek als cultureel dynamisch schakelcentrum, ontstaat met deze plannen een enigszins tegenstrijdig beeld van de situatie in Den Bosch; we zouden kunnen zeggen dat hiermee, met de woorden van Deleuze en Guattari, de opkomst van een rizomatisch samenhangende veelheid aan heterogene podia waar de Verkadefabriek voor staat, doorsneden wordt door een residuele boomgestructureerde opvatting over theaterbouw en het functioneren van theaterpodia. Er wordt met deze plannen teruggegrepen op een combinatie van een negentiende-eeuwse opvatting over theater voor grote zalen en twintigste-eeuws grootschalig entertainment. De geplande nieuwe schouwburg wordt een van de grotere schouwburgen in zijn soort van Nederland, een nieuw podium met een traditionele intermediaire rol tussen uitvoerende podiumkunstenaars en publiek.

Aan de ene kant zien we dat organisaties als de Verkadefabriek zich structureel afvragen hoe kunst en cultuur een constituerende rol kunnen spelen in de stadsgemeenschap van Den Bosch en wat het podium daaraan kan bijdragen met zo min mogelijk overheidsgeld. Aan de andere kant wordt een grote hoeveelheid overheidsgeld geïnvesteerd in traditionele theatergebouwen, terwijl de recente geschiedenis leert dat dit soort kostbare gebouwen waarschijnlijk voornamelijk gebruikt gaat worden voor lokale gemeenschapsactiviteiten en voor commerciële bespeling en verhuur. Het marktaandeel van de gesubsidieerde podiumkunsten fluctueerde anno 2010 nog rond de 15 procent van de programmering van dergelijke zalen en is sindsdien iets toegenomen maar niet substantieel, zo is te zien op de trendmonitor van het Ministerie van Onderwijs, Cultuur en Wetenschap. ${ }^{119}$ Het kan daarom bijna niet anders of er zal in dergelijke grote projecten commercieel en zakelijk geprogrammeerd moeten gaan worden.

\footnotetext{
${ }^{118}$ Op donderdag 15 mei 2014 verscheen er een special over theaterbouw in tijden van crisis in het Cultureel supplement van het NRC Handelsblad. In de special de onderzoeksresultaten van een door het NRC Handelsblad uitgevoerd journalistiek sectoronderzoek.

${ }^{119}$ Retrieved March 20, 2015, from http://www.trendsinbeeld.minocw.nl/grafieken/4_1_4.php
} 


\subsection{Conclusies}

De Verkadefabriek is in korte tijd een rol gaan spelen als een intercultureel podium voor de stad 's-Hertogenbosch en verre omgeving. De verzameling podia van de Verkadefabriek toont dat het gebouw het samengaan van uiteenlopende culturen als het ware performt; de performativiteit van het gebouw kleurt een streven naar interculturele ontmoetingen. Theater maakt nog slechts een bescheiden deel uit van de totale programmering. Activiteiten als film, dansavonden, cabaret en diverse festivals trekken de grootste groepen publiek. Het hoort landelijk bij de goed functionerende podia. ${ }^{120}$ De Verkadefabriek is in dat opzicht een laboratorium voor cultureel ondernemerschap. Aan het eind van de onderzoeksperiode werd 25 procent van de exploitatie gedekt door subsidies, de andere 75 procent door eigen inkomsten. De directie streeft op de lange termijn naar volledige financiële onafhankelijkheid van de overheid.

De Verkadefabriek heeft als een schakelcentrum de intentie ontmoeten in de breedste zin van het woord meer sturend principe te laten zijn dan verheffen of het spreiden van canonieke cultuur. Verschillende publieksegmenten vinden hun weg naar de Verkadefabriek; in en door het gebouw kruisen elkaars wegen. De publieksruimtes ademen daarbij als geheel een informele en neutrale sfeer. Tijdens schakelmomenten kunnen allianties ontstaan tussen verschillende culturen ('hoog'-'laag', westers-nietwesters, digitaal gemediatiseerd-analoog). Het totaalconcept van de Verkadefabriek gaat niet uit van één bepaalde historisch of traditioneel gedefinieerde podiumkunstencanon maar van het elkaar treffen van mensen rond cultuuruitingen van verschillende aard en herkomst. Naast het potentiële schakelen tussen verschillende publiekssegmenten, voltrekken zich ook transformaties van woord naar beeld, van betekenis naar ervaring, van semiotiek naar fenomenologie. In hoeverre het nagestreefde ontmoeten tussen de verschillende publieksgroepen daadwerkelijk plaatsvindt en in wat voor vormen, valt nog niet met precisie te concluderen, dat zal zich op de langere termijn openbaren. Ook is daar andersoortig onderzoek voor nodig.

Niet alle verschillende bevolkingsgroepen van 's-Hertogenbosch en omgeving vinden elkaar in de Verkadefabriek, maar wel veel en het publiek komt in gestaag groeiende aantallen. Bevolkingsgroepen die tot het kansarme deel van de samenleving gerekend kunnen worden of streng christelijk zijn of streng islamitisch, zullen zich er wellicht niet automatisch thuis voelen en mengen met stedelijk uitgaanspubliek, filmliefhebbers, of met hoog opgeleid publiek voor geëngageerde performances en

\footnotetext{
${ }^{120}$ Op basis van kaartverkoop en omzetten wordt in 2012 het bezoekersaantal per jaar geschat op 250.000, waarvan ongeveer 120.000 voor door de Verkadefabriek georganiseerde culturele programmering. Als filmtheater behoort de Verkadefabriek qua bezoekersaantallen tot de top 10 van Nederland (I. Van Heeckeren, persoonlijke communicatie, 9 november 2012).
} 
ingewikkeld westers theater- en dansrepertoire. Als ontmoetingsplek in de stad heeft de plek wel een bredere werking getoond dan de vaak op eenduidige functies gerichte instituties als de bioscoop, de stadsschouwburg, het café-restaurant of het zaaltje van het amateurgezelschap. De gedeelde ervaring van grote delen van deze publieksgroepen lijkt ervoor te zorgen dat er ook een meer dan gemiddelde betrokkenheid geconstateerd kan worden bij debattenreeksen over maatschappelijke thema's zoals die in elke stad of regio spelen (integratie, lokale en landelijke verkiezingen, kunst- en cultuursubsidies, landbouwproblemen in de provincie). Er is bij elk type activiteit sprake van een open sfeer, er is weinig tot niets te merken van scherpe scheidingen tussen publiekscodes of opgelegde gedragsvoorschriften. Wellicht heeft dit te maken met het feit dat velen in meer dan één hoedanigheid gewend zijn aan de plaats van handeling. Ze zijn bij het bezoeken van een politiek debat of bij een maaltijd in het restaurant eigenlijk 'thuis', als theatermaker, als vrijwilliger, als familielid van een leerling van de amateurtheaterschool, als fervent filmliefhebber; velen delen de plek als prosument. Daardoor is men iedere keer weer een klein beetje minder gast of klant.

De Verkadefabriek is een van de voorbeelden van het groeiende hergebruik van industrieel erfgoed in de afgelopen decennia. Lehmann noemt voorbeelden die hij waarnam en bestempelde ze als vitale zones van een veranderend landschap: lege kantoorgebouwen, fabrieken, kazernes, galerieën en parkeerplaatsen (Lehmann, 1999, p. 216). Deze voormalige overgangszones voor wat de tegencultuur heette, zijn in veel gevallen reguliere culturele locaties als de Verkadefabriek geworden. Op basis van de waargenomen praktijk van het podium de Verkadefabriek kan geconcludeerd worden dat deze transformerende podiumdifferentiatie zich heeft doorontwikkeld tot gangbare praktijk. Podia als de Verkadefabriek zijn in termen van Even-Zohar in hun functioneren verhuisd van de periferie naar het centrum van de cultuurbeleving van de stad.

De groeiende diversiteit van podia waarop een veelheid aan performatieve cultuuruitingen zich manifesteert, problematiseert de werking van gevestigde theaterpodia. Traditionele stadsschouwburgen en aanverwante podia zijn voor wat betreft het segment van hun gesubsidieerde programmering niet meer de centrumpodia van het culturele leven, hun positie is subcultureel geworden naast diverse andere subculturen. Het lijkt voor traditionele podia ingewikkelder om duurzame nieuwe publieksstrategieën te ontwikkelen dan voor relatief nieuwe fysieke dan wel virtuele podiumvarianten. De laatste zijn meer ingesteld op modulair schakelen tussen interculturele, intermediale en internationale cultuuruitingen en interessegroepen. Grote culturele Europese festivals als het Szigetfestival in Boedapest of het Edinburgh International Festival, waar jongeren uit geheel Europa en de rest van de wereld in groten getale naar toe trekken, zijn geen traditionele genrefestivals meer. 
Ongeveer alle denkbare kunstvormen vinden er een plaats. Op Nederlandse festivals als Oerol, Lowlands, Incubate, Best Kept Secret, Into The Great Wide Open, STRP Festival en de Zwarte Cross genieten tienduizenden niet alleen van muziek maar ook van theater, dans, film, performances, documentaires, allerlei artistieke mengpraktijken en zelfs van debatten en politieke fora met politieke kopstukken van het moment. ${ }^{121}$ Over het reguliere Nederlandse en Vlaamse club- en uitgaanscircuit of over modecentra zijn vergelijkbare uitspraken te doen in de zin van differentiering van de programmering en van de functie van schakelcentra die ze vervullen.

De transformatie van theaterpodium naar schakelcentrum heeft de potentie om bij te dragen aan het besef van een associatieve samenhang van het performatieve als kenmerkend deel van het in de tijd zijn aan het begin van de 21 e eeuw. Om een rol te kunnen blijven spelen waar het gaat om het begrijpen en bevragen van de tijd, zullen podia innovatieve publiekstrategieën dienen te ontwikkelen. Kunst- en cultuurbeleving zou daardoor weer meer een zaak kunnen worden van diverse grotere groepen betrokkenen in plaats van een vanzelfsprekendheid voor een relatief kleine kring van ingewijden.

\footnotetext{
${ }^{121}$ Vanaf de jaren zeventig van de vorige eeuw is er in Nederland sprake van een gestaag groeiende festivallisering (1980: 150 festivals per jaar; 2013: 774). Voorheen ging het overwegend om muziekfestivals, nu is er ook steeds meer sprake van literatuur, film en theaterfestivals. Van 2005 - 2013 vond er een groei plaats van 29 procent, in 2013 kon het publiek kiezen uit 65 festivals per maand. In totaal bezochten in 2013 21,5 miljoen mensen een festival, samen gaven ze ruim 166 miljoen euro uit. Deze gegevens komen uit een marktonderzoek ('Festivalmonitor 2014') uitgevoerd door Onderzoeksbureau Respons. (Jong, 2014)
} 



\section{Hoofdstuk 5 Theateropleiding in transitie}

"Make rhizomes, not roots, never plant! Don't sow, grow offshoots! Don't be one or multiple, be multiplicities! Run lines, never plot a point!" (Deleuze \& Guattari, 2007, p. 24).

\subsection{Inleiding}

In de vorige twee gevalstudies hebben we gekeken naar de eerste twee elementen van het theatersysteem, naar een theatergezelschap en naar een podium. De gevalstudies en de conclusies die ik daaraan verbind tonen veranderingen in de relaties tussen theaterproducenten, podia en publiek. In deze derde studie neem ik het derde element uit het theatersysteem onder de loep, de theateropleiding. Voor de aanvankelijk traditionele theateropleidingen geldt dat ze zich wel moeten verhouden tot de actuele wisselwerking tussen dominante, residuale en opkomende performatieve praktijken die in deze studie beschreven worden, omdat zij hun studenten opleiden voor de hedendaagse praktijk. De vraag die hier centraal staat luidt: hoe gaan theateropleidingen om met deze veranderende praktijk? Hoe hebben in de afgelopen decennia Lehmanns postdramatische ideeën, Fischer-Lichtes gedachten over een performance-esthetiek en ontwikkelingen rond opkomende media hun weg gevonden naar de curricula van theateropleidingen?

Om hier een beeld van te krijgen beschouw ik ontwikkelingen van de laatste twee decennia op de Nederlandse theateropleiding de Toneelacademie Maastricht. Deze opleiding is in zijn soort, als een van de vier opleidingen in Nederland met een licentie om op te leiden voor de professionele acteurspraktijk, exemplarisch voor de theateropleidingen; alle opleidingen proberen zich op eigen kracht zowel als gezamenlijk in een structureel sectoroverleg ${ }^{122}$ te verhouden tot het veranderende vakmanschap van de theaterkunstenaar in de 21 e eeuw en worden daarin gesteund

\footnotetext{
${ }^{122}$ Het sectoroverleg van bekostigde Nederlandse theateropleidingen op hbo-niveau is geregeld in het Netwerk Theater. In het Netwerk Theater zijn alle rijksbekostigde Nederlandse theateropleidingen op hboniveau vertegenwoordigd.
} 
door de HBO- raad (Commissie Dijkgraaf, 2010). ${ }^{123}$ Mijn keuze voor de Toneelacademie Maastricht wordt daarbij mede bepaald door het feit dat ik de opleiding goed ken. Al eerder gaf ik aan dat ik me ervan bewust ben dat kiezen voor het instituut waar ik werk als object van onderzoek, het risico in zich draagt van een te geringe kritische distantie. Om dit methodologische probleem op te lossen doe ik een beroep op de practice-as-researchbenadering. Mijn onderzoeksmethode voor deze gevalstudie is die van de participerende waarneming. Het empirische materiaal wordt gevormd door voorbeelden uit de opleidingspraktijk, waarbij ik steun op een ruim twintigjarige ervaring als docent en onderzoeker aan de Toneelacademie Maastricht, gecombineerd met werkervaringen in en rond de theaterpraktijk. ${ }^{124} \mathrm{lk}$ analyseer het al doende zoeken van opleiders en studenten naar manieren om zich te verhouden tot het veranderende veld van de theaterprofessional. Ik beschrijf dit zoeken met een Deleuziaanse cartografie vol vertakkingen, die de beweeglijkheid van een gevestigde theateropleiding recht kan doen. De manier waarop ik daarbij heb gedacht voldoende wetenschappelijke distantie in acht te nemen, licht ik hieronder kort toe.

In Balans van de sociologie (1974/1990) schetst de Nederlandse socioloog Johan Goudsblom de noodzaak voor onderzoekers tot het ontwikkelen van een zekere mate van wij-perspectief.

'Een wij-perspectief is voor sociologen onontbeerlijk: "indien de onderzoeker het handelen van mensen wenst te begrijpen, is het noodzakelijk dat hij objecten van hun handelen ziet zoals zij deze zien" (Blumer 1969, p. 51). Een socioloog moet de taal verstaan, de bedoelingen herkennen van de mensen die hij bestudeert' (Goudsblom, 1990, p. 128). ${ }^{125}$

Tegelijkertijd zal hij zich niet totaal moeten identificeren met de te onderzoeken groepen en kritisch moeten blijven tegenover de betekenis die de onderzochten zelf geven aan hun handelen. Hij doet dat door de materie niet alleen van binnenuit te beschouwen maar ook van buitenaf, met een zij-perspectief (Goudsblom, 1990, pp. 121-146). Wat Goudsblom definieerde als een wij-perspectief, raakt de manier waarop

\footnotetext{
${ }^{123}$ Per 18 april 2013 is de naam HBO-raad veranderd in Vereniging Hogescholen. In de tekst gebruik ik de naam HBO-raad omdat de documenten waarnaar ik verwijs, stammen uit de tijd dat de organisatie die naam nog droeg.

124 Sinds 1991 ben ik als docent dramaturgie, als afdelingscoördinator en vanaf 2002 tevens als onderzoeker verbonden aan de Toneelacademie. Mijn werkzaamheden als docent heb ik vrijwel altijd gecombineerd met deeltijdwerkzaamheden in de theaterpraktijk die voor theaterwetenschappers en dramaturgen gebruikelijk zijn (theaterrecensent, onderzoeker, beleidsadviseur, bestuursvoorzitter van een gezelschap, en lid van de dramaturgenstaf van een theatergezelschap). Zie CV.

${ }^{125}$ In Balans van de Sociologie (1990, p. 128) citeert Goudsblom met deze woorden Herbert Blumer uit diens boek Symbolic interactionisme: perspective and method (1969, p. 51).
} 
Robin Nelson practice as research definieert (Nelson, 2013). Als reflective practitioner jarenlang ondergedompeld zijn in het doing-thinking van een theateropleiding in nauw contact met de actuele theater- en filmpraktijk, heeft mij en mijn collega's substantiële inzichten opgeleverd. Deze al doende verworven inzichten staan, zo stelt Nelson en ik volg hem daarin, voor een specifiek soort kennis van de werking van de kunstenpraktijk zelf. Om toch, Goudsblom volgend, enige afstand te betrachten is het noodzakelijk daarbij waar mogelijk ook een zij-perspectief in acht te nemen, bijvoorbeeld door in de analyse van het onderzoeksmateriaal ook documenten te betrekken die een zij-perspectief in zich dragen, zoals accreditatierapporten van de opleiding. Op deze manier opgevat lijkt mijn betrokkenheid bij het object van onderzoek niet onverenigbaar met het verantwoord uitvoeren van deze gevalstudie.

In paragraaf 5.2 zal ik een aantal kenmerkende aspecten van het transitieproces op de Toneelacademie de revue laten passeren, achtereenvolgens de differentiatie van het onderwijsaanbod, de implementatie van onderzoek, de groeiende aandacht voor interculturele ontwikkelingen en de toenemende internationale oriëntatie van de opleiding. In paragraaf 5.3 analyseer ik het empirisch materiaal tegen de achtergrond van studies en documenten die richting geven aan de inrichting van theateropleidingen en in 5.4 trek ik conclusies.

\subsection{Toneelacademie Maastricht}

De theaterfaculteiten in Nederland zijn onderdeel van grotere hboonderwijsorganisaties met hoofdzakelijk bacheloronderwijstrajecten. Alle hbotheateropleidingen zijn bacheloropleidingen, op sommige plaatsen bestaan masteropleidingen voor specialistische vervolgstudies, meestal in samenwerking met een universiteit. De opleidingen verschillen van elkaar in afstudeerrichtingen (acteursopleiding, theatervormgeving, opleiding theaterdocent, regieopleiding, dansopleiding, performanceopleiding, musicalopleiding, e.a.), die in verschillende combinaties worden aangeboden onder diverse zogeheten CROHO-licenties. ${ }^{126}$

De Toneelacademie Maastricht is onderdeel van de Faculteit van de Kunsten Maastricht (Arts Faculty Maastricht, AFM) en kent twee rijksgecertificeerde licenties: Theater en Docent Theater. De opleiding Theater kent twee uitstroomprofielen: acteur en theatermaker. Het uitstroomprofiel acteur kent twee afstudeervarianten, acteur en performer. Het uitstroomprofiel theatermaker kent eveneens twee afstudeervarianten, regisseur en theatervormgever. Binnen de laatste variant kan gekozen worden voor de specialisatie scenograaf of theaterkostuumvormgever. De opleiding Docent Theater kent geen specialistische uitstroomprofielen, wel twee studievarianten: een nascholingstraject dat is ondergebracht binnen een

${ }^{126} \mathrm{CROHO}=$ Centraal Register Opleidingen Hoger Onderwijs. 
postacademische opleiding Docent Theater (PAO) en een deeltijdopleiding met de naam Parttime opleiding Docent Theater (Kort \& Olaerts, 2014).

De pijlers waarop het curriculum van de traditioneel ambachtelijke theateropleiding aanvankelijk rustte waren: een theatertechnische training van stem en lichaam, vakgerichte studie van westerse dramaturgie en repertoire, cultuurbeschouwing en de structurele relatie van de opleiding met de theaterpraktijk. In de afgelopen decennia is naast dit basale theateronderwijspakket ruimte gemaakt voor andere dan Aristotelische regiestijlen, de filmcultuur, digitale technologie, mediakritiek, performance, interdisciplinariteit en cultureel ondernemerschap. Dit proces is niet iets van de laatste decennia, in feite is het curriculum van de Toneelacademie vanaf de oprichting in 1950 in een longitudinaal proces langzaam maar zeker evolutionair gedifferentieerd. Voor deze gevalstudie is het vooral van belang ons af te vragen hoe die differentiatie zich de laatste decennia versneld heeft ontwikkeld. Hierna volgt, na een korte terugblik op het verleden, een schets van deze versnelde differentiatie van bronnen, repertoire en werkwijze. In het vervolg van deze paragraaf ga ik nader in op het implementeren van onderzoek in het kunstvakonderwijs, op interculturele processen die de opleiding raken en op internationaliseringstendensen.

\section{Differentiatie van het theateronderwijs: intermedialiteit en technologie}

Toen na de Tweede Wereldoorlog in het kader van cultuurspreiding nieuwe schouwburgen werden gebouwd en gezelschappen werden gesubsidieerd, waren meer acteurs en actrices nodig dan aanvankelijk voorhanden waren (Maanen, 1997, p. 79). ${ }^{127}$ In het licht van deze behoefte werd in 1950 de Toneelacademie Maastricht opgericht. Er werden acteurs en actrices opgeleid door training van stem en beweging en het bijbrengen van repertoirekennis, dramaturgie en theatergeschiedenis. Tot 1970 veranderde er weinig aan het aanvankelijke curriculum.

In 1971 werd, naast de opleiding tot acteur/actrice, gestart met een dagopleiding voor docenten drama, in 1977 gevolgd door een parttimervariant hiervan. In de opleidingstrajecten stond het westerse toneelrepertoire centraal. Er was aandacht voor speltheorieën van Stanislavski, Brecht en Grotowski, met in het verlengde ervan workshops op Amerikaanse leest geschoeid. Tevens ontstond aandacht voor laattwintigste-eeuws Engels en Frans repertoire met bijbehorende speelstijlen. De academie in Maastricht heeft zich nooit willen profileren als een genreschool, dat werd

\footnotetext{
${ }^{127}$ Van Maanen zegt daar: 'Om die gezelschappen op niveau te doen functioneren, zijn er duidelijk meer acteurs en actrices nodig dan er aanvankelijk beschikbaar waren. Dit gegeven leidt tot de oprichting van enkele nieuwe toneelopleidingen, naast de enige die, vanaf 1874 , in de behoefte aan tonelisten had voorzien, "De Toneelschool" te Amsterdam'.
} 
te beperkend gevonden (Dodemont, 1998). Tezelfdertijd veranderde de beeldtaalcanon door de toenemende invloed van film en televisie. Daarbovenop opende in 1969 de Aktie Tomaat de poorten naar een ongebreidelde drift tot onderzoek naar speelstijlen en verschijningsvormen (Meyer, 1994). Nederlandse pioniers als Jan-Joris Lamers (Werkteater en Maatschappij Discordia), iets later Frans Strijards (Art \& Pro) en Gerardjan Rijnders (Fact, Globe en Toneelgroep Amsterdam) lieten sporen na in het theaterlandschap waar ook de opleidingen niet omheen konden. Later, in de jaren tachtig, maakte de theaterwereld tijdens wat de Vlaamse golf is gaan heten, kennis met Vlaamse theatervernieuwers als Jan Fabre, Anne Teresa De Keersmaeker, Jan Lauwers en de Needcompany, de jonge Ivo van Hove en het collectief van de Blauwe Maandag Company onder leiding van Luc Perceval.

In de loop van de jaren 1990 gingen theateropleidingen zich verhouden tot veranderende dramaturgie- en spelopvattingen. Open dramaturgie, bewegingstheater, montagetheater, performance, film en ander mediagebruik werden druppelsgewijs opgenomen in leerplannen die werden aangepast aan een zich vernieuwende theateresthetiek. Camera's en microfoons waren in de jaren zestig, zeventig al geleidelijk geïntroduceerd en in de loop van de jaren tachtig en negentig was er een vanzelfsprekende band gegroeid tussen de gevestigde theateropleidingen en de filmen televisiesector. Aanvankelijk een bijproduct van voor theater opgeleiden, werd deze sector een belangrijk hoofdvakgebied. Met deze specifieke aandacht voor cameraacteren werd vanaf begin jaren zeventig het traditionele curriculum van de theateropleiding in zekere zin opengebroken. Camera's en microfoons werden gaandeweg geaccepteerd als extensies van het acterende lichaam; de potentieel toegevoegde dramaturgische meerwaarde en extra narratieve mogelijkheden van live toepassingen van beeld- en geluidsdragers in het theater en het gemak van steeds toegankelijker software, werden pas veel later in volle omvang duidelijk (Merx, 2009).

Een tekenend voorbeeld van een transitieproces waarin het bestaande curriculum meer recent werd opengebroken, was de start van een nieuwe afstudeervariant in 2000, die van de opleiding tot theatraal performer. ${ }^{128}$ Onder invloed van technologische en theateresthetische veranderingen in productie, distributie en receptie van podiumkunst (Lehmann, 1999; Fischer-Lichte, 2004) ontstonden grensgebieden waar de opleiding zich qualitate qua toe had te verhouden. De opleiding tot performer richt zich op internationale voorbeelden van performancekunst, beeldende kunst, de auteursfilm, performatieve ontwikkelingen in het actuele theater en op afgeleide vormen hiervan in toegepaste kunstdomeinen. De performancestudenten worden geconfronteerd met grensverleggende 'taal' van zeer verschillende kunstenaars zoals Erwin Wurm, Romeo Castellucci, Lars von Trier, Klaus

\footnotetext{
${ }^{128}$ In 2003 studeerde Lizzy Timmers als eerste en in dat jaar enige performancestudent af aan de Toneelacademie.
} 
Nomi, Tracey Emin, Ai Wei Wei, Forced Entertainment, Chris Burden, Needcompany, Francis Alÿs, Sophie Calle en David Lynch. Deze confrontatie met actuele performatieve praktijken is gericht op het verleggen van eigen grenzen en het radicaliseren van de eigen vormtaal, met specifieke aandacht voor het productioneel beheersen van technologische middelen als geluidsversterking, belichting, computersoftware en beelddragers (Toneelacademie, 2015, p. 5).

$\mathrm{Na}$ vijftien jaar heeft deze werkwijze inmiddels ook de andere studentgroepen (acteurs, studenten scenografie, regisseurs) besmet in de zin van verrijkt, net zoals andersom geldt dat beproefde onderdelen en trainingen van de acteurs- en regisseursopleiding zijn opgenomen in het curriculum van de performanceopleiding. Meteen vanaf het begin in de propedeuse en ook in de rest van hun studie krijgen alle studenten te maken met studieonderdelen die strikt genomen buiten hun eigen hoofdvak vallen. Het hoofdvak van de uitvoerende richtingen bestaat voor acteurs uit teksttoneel en camera-acteren, voor de performancestudenten is dat het maken van performances. Voor de regiestudenten is het hoofdvak het uitvoeren van regies en voor de theatervormgevers het tekenen, ontwerpen en vormgeven van theater- en filmbeeld. Het vierde jaar is voor alle studenten een overgangsjaar naar de praktijk en bestaat voor het grootste deel uit stages. ${ }^{129}$ In de propedeuse worden naast het hoofdvak theorielessen en technische training- en expressielessen gegeven. In deze hoofdvakondersteunende werksessies wordt impliciet en expliciet aandacht geschonken aan veranderingen binnen de actuele artistieke praktijk, die vanaf dag één van de opleiding een reflectief sturende rol speelt.

Hierna zal ik eerst aandacht schenken aan drie praktijkgestuurde studierichtingdoorkruisende projecten in de propedeuse. Dit zijn als het ware schakelmomenten tussen zelfreflectie, basale opleidingsonderdelen, verschillende vakspecialismen en de hedendaagse praktijk. Vervolgens beschrijf ik een hogerejaarsproject dat schakelt in de grensgebieden tussen de kunst- en de nietkunstwerelden. Daarna ga ik in op de integratie van intermedialiteit en technologie in het gehele curriculum van de opleiding tegen de achtergrond van een veranderend beroepsperspectief van de voor theater opgeleide student.

\footnotetext{
${ }^{129}$ Er wordt door alle Maastrichtse studenten stage gelopen door bijvoorbeeld gastrollen te spelen in producties bij grote en middelgrote gesubsidieerde gezelschappen in Nederland en Vlaanderen als het Nationaal Toneel, Toneelgroep Amsterdam, het Zuidelijk Toneel, het Ro Theater, Toneelgroep Maastricht, Artemis, en het Noord Nederlands Toneel, NTGent, Toneelhuis, maar ook in speelfilm- en televisieproducties en bij kleinere theatergezelschappen. Regiestudenten werken in hun vierde jaar vaak als regieassistent bij professionele producties of maken zelfstandig of onder de vleugels van een regisseur of een groot gezelschap een voorstelling. Vormgevers zijn de afgelopen jaren in hun vierde jaar veel in de Duitse theaterwereld actief geweest.
} 
Project Shakespeare. Kleine groepjes van zes tot acht eerstejaarsstudenten werken niet-studierichtingspecifiek de eerste drie weken van hun studie zelfstandig aan een voorstelling. Na een korte introductie rond cameragebruik, scriptschrijven en een aantal basale filmprincipes, krijgt elke groep een toneeltekst van William Shakespeare toegewezen. De studenten worden geacht zelfstandig een opvoering voor publiek tot stand te brengen, waarbij elke interpretatie en vormgeving is toegestaan. Bovendien wordt van hen gevraagd om voor het stuk een filmtrailer te maken. Ze hebben daar de vijftien hoofdvakuren per week voor en ze kunnen een docent en een studiobeheerder aanspreken voor technisch advies en ondersteuning. Alles wat de studenten zelf meebrengen uit hun pre-Toneelacademiebestaan aan cameragevoeligheid of aan vaardigheden met software voor montage en beeldbewerking, wordt ingezet.

Project Theatrale Column. Anderhalve maand lang werken alle propedeusestudenten aan een individuele performance, om die uiteindelijk op te voeren voor een publiek van 100 mensen. Onderdeel van de opdracht is om zich te verhouden tot minder traditioneel theaterinstrumentarium. Ze worden daartoe persoonlijk een à twee maal per week uitgedaagd door een duo van een speldocent en een theoriedocent (dramaturg of cultuurfilosoof) dat hen confronteert met relatief onbekende performatieve domeinen, met minder voor de hand liggend vormgevingsgereedschap en met metaforen uit disciplines als de beeldende kunst, de fotografie, de film- en televisiegeschiedenis, en uit de beeldcultuur van nieuwe media. Het staat de studenten vrij om te experimenteren met de publieksopstelling en met de inzet van digitale media.

Project Televisie maken. Sinds 2007 worden de studenten van de vier verschillende studierichtingen in het praktijkproject Televisie maken geconfronteerd met de praktisch en reflectief op te lossen problemen bij het maken van een televisieprogramma. Ze doen dit in kleine groepen en in coproductie met de publieke lokale omroep TV Maastricht, niet allemaal en niet uitsluitend als acteurs of actrices, wat voor de hand zou liggen, maar als medeverantwoordelijke producenten, cameramannen en -vrouwen, licht- en geluidstechnici en locatiemanagers. In anderhalve maand tijd maken zij korte televisie-items. Onderstroom, zoals het programma heet, is een tv-magazine voor Maastricht en omstreken, waarin jonge regisseurs, acteurs, theatervormgevers en performancestudenten een tv-programma maken waarin zij hun relatie tot de stad Maastricht uitdrukken. Elke aflevering bestaat uit vier items met een totale uitzendtijd van twaalf tot veertien minuten. Al het productiewerk wordt door de studenten gedaan. Voor de opnamedagen krijgen de groepen de beschikking over een camera en over professionele geluidsapparatuur. ledere week krijgt één groep assistentie van een professionele cameraman van TV Maastricht. De korte studentfilmpjes worden daadwerkelijk uitgezonden. Na de eerste 
edities werd geconcludeerd dat studenten steeds meer organisch omgaan met beelden geluidsdragers en met de wetten van beelddramaturgie en digitale eindmontage. Bepaalde beelduitsnedes, cameravoering, montagetechnieken en filmsequenties uit het cinematografisch repertoire hebben zich net zo geïncorporeerd in hun systeem als enige decennia geleden verzen van Shakespeare, teksten van Euripides, Goethe, Racine of Albee in het systeem van literair dramatisch gepassioneerde gymnasiasten. De snelheid van opnemen van door professionals aangereikte vaardigheden neemt elk jaar toe.

Nadat de studenten in de propedeuse meteen vanaf de start geconfronteerd zijn met de breedte van het performatief spectrum, komen ze in latere opleidingsjaren ook binnen hun eigen hoofdvak met intermediaal gedifferentieerd repertoire, bronnen en werkwijzen in aanraking. In de eerste plaats in reguliere hoofdvakprojecten en workshops en in de tweede plaats in schakelmomenten van projecten in de grensgebieden tussen kunst- en niet-kunstwerelden.

Een voorbeeld van de introductie die studenten krijgen in intermediale dramaturgische strategieën zijn de technolabprojecten waar alle studenten mee te maken krijgen. In kleine groepen hebben ze in het tweede of derde studiejaar in een technolabproject ieder de beschikking over een opdrachtspecifieke digitale werkset. Die bestaat uit een of meer krachtige laptopcomputers uitgerust met een beeldbewerkingprogramma; een camera en een of meer beamers; zo mogelijk een eigen werkruimte en professionele montagefaciliteiten. De afgelopen jaren (2005 2015 ) is vooral gewerkt met het softwareprogramma Isadora. Dit is een programma dat interactieve controle van digitale media mogelijk maakt, met de nadruk op real time-bewerking van digitale video. Het is ontwikkeld door Mark Coniglio, een van de twee artistiek leiders van Troika Ranch, een in New York gevestigd gezelschap dat al vanaf de jaren 1980 opereert op de grenzen van dans, performance, theater en technologie. Het programma biedt losse digitale bouweenheden die bijna ongelimiteerd aan elkaar gekoppeld kunnen worden. Hiermee is het mogelijk om artistieke impulsen in een performance of installatie op de voet te volgen door eenvoudige on demand-aansturing van projecties, sounds capes, streaming video of belichting. ${ }^{130}$ Traditionele theaterliefhebbers beschouwen dit soort technologie vaak als exposure van apparatuur die, zeker omdat alles zichtbaar is, indruist tegen de illusionistische aard van dramatische kunst en theater. In gesprekken met studenten

\footnotetext{
${ }^{130}$ Het is voorstelbaar dat in de loop der tijd ook andere programmatuur gebruikt gaat worden naast of in plaats van Isadora. Op de softwaremarkt verschijnen talloze programma's die in een of andere toepassing interessant kunnen zijn voor de podiumkunsten en/of hybride aanpalende terreinen. Opleidingen als de Toneelacademie Maastricht maken innovatieve afwegingen in combinatie met de gebruikersvriendelijkheid van de software in hoger onderwijs situaties en artistiek onderzoek.
} 
die ermee werkten en hun begeleidende docenten bleek echter dat het hun meer ging om de potentiële performativiteit van de technologie en de potentieel gelaagde dramaturgie die dat opleverde dan om exposure van spektakelspeelgoed.

De studenten weten snel hoe geprojecteerd beeld, computer, beamer, camera en microfoon, in combinatie met live uitgevoerde acties, meerwaarde op kunnen leveren voor hun voorstelling, video-installatie of performance. Door dit anders spelen, vóór en vooral mét de camera, leren ze reeksen beelden te construeren die hen voorbij de klassieke film- en theaterdramaturgie voeren. Grote delen van deze digitale codes, kennis en vaardigheden zitten overigens anno 2015 al in de collectieve culturele bagage van de meeste studenten, ze zijn er als digital natives mee opgegroeid (Prensky, 2001). In dit project zijn de studenten en hun begeleidende docenten vooral gezamenlijk op zoek naar de dramaturgische en performatieve meerwaarde rond onderzoeksvragen als: welke mogelijkheden biedt deze software voor de fysieke omgeving van het acteren of performen, voor de vorm van performances? Wat zijn de performatieve consequenties van de inzet ervan ${ }^{131}$ In deze reflectie toont zich het veranderingsproces dat zich ontrolt wanneer een traditionele vaktraining wordt geïnjecteerd met actuele digitale mogelijkheden. Als studenten een of meer edities meegemaakt hebben, zo leert de ervaring, zien we de toepassingen en vaardigheden in hun latere werk terug.

Tot ongeveer 2010 lag wat betreft de intermediale ontwikkelingen het zwaartepunt op de Toneelacademie bij de technolabprojecten, bij het instrumenteel en verkennend inzetten van nieuwe media en bij concrete investeringen op dit vlak (netwerken, financiële middelen). Vanaf die eerste periode tot heden wordt technologie en intermedialiteit meer en meer verweven met de dagelijkse opleidingspraktijk en ligt de nadruk vooral bij mediakritische vertelstrategieën: wat zet ik wanneer en om wat voor redenen in? Het intermediale staat daarbij voor mediabesmetting, voor cross mediale toepassingen. Meer en meer stuurt de student hierbij de inzet van media en middelen zelf aan (Missotten, 2014, pp. 3-4).

Daar waar de afgelopen decennia in Nederland en in de rest van Europa vaak nieuwe opleidingen werden ontworpen voor toegepaste technologische kunstdomeinen, is er in Maastricht voor gekozen om technologische toepassingen te integreren in het curriculum van de bestaande traditioneel ambachtelijke theateropleiding. Geen specialistische eilanden maar dominante, residuele en

\footnotetext{
${ }^{131}$ In 2005 en 2006 werden de eerste pilotedities van de technolabworkshops begeleid en gecoacht door spel- en performancedocent Woody Laurens, toenmalig lector Nieuwe Theatraliteit Chiel Kattenbelt, film- en videodocent Jo van Laar, ICT deskundige Hans Lasschuit en dramaturg Henk Havens. Later edities werden gaandeweg meer 'volwassen' praktijkwerkplaatsen met een grotere eigen inbreng van de studenten en onder praktijkbegeleiding door Woody Laurens, Jo van Laar en Hans Lasschuit.
} 
opkomende performatieve uitingen die onder één dak met elkaar interfereren, zoals dat in de echte artistieke wereld ook het geval is. Het oprekken van de grenzen van de live performance op basis van nieuwe theater- en performance-esthetiek in de kunstenpraktijk, dwingt de Toneelacademie tot deze aanpassingen van curriculum en werkwijze. Naast traditionele theaterregisseurs worden ook professionals uit de actuele hybride artistieke praktijk uitgenodigd als gastdocenten. In december 2008 schreef de Netherlands Quality Agency (NQA) na het accreditatietraject van de Toneelacademie ten behoeve van de Nederlands Vlaamse Accreditatie Organisatie (NVAO) het volgende in haar rapportage:

'De Toneelacademie Maastricht vat haar rol als kunstopleiding nadrukkelijk op als een schakelfunctie. Een schakel tussen traditie en vernieuwing in de podiumkunsten. Zo profileert de Toneelacademie zich als een opleiding waarin zowel het klassieke verzendrama (Vondel) als de multimediale performanceprojecten thuis zijn. Langs deze weg is de Toneelacademie een schakel in het doorgeven van verhalen en tradities en het onderzoeken van nieuwe wegen voor die verhalen' (NVAO, 2008, p. 56).

Hiermee in overeenstemming is het feit dat het doorgeven van verhalen steeds meer plaatsvindt op nieuwe digitale podia. ${ }^{132}$ Deze nieuwe beeldpodia vormen een eigen artistiek hybride culturele dynamiek met nieuwe assemblagetoepassingen waarbij gevestigde film- en televisie-industrieën een subculturele rol op de achtergrond lijken te spelen. Filmwetenschapper en hoogleraar media en cultuur in Amsterdam Patricia Pisters formuleert deze ontwikkeling als volgt:

'Hoewel er nog altijd dominante media zijn aan te wijzen (Hollywood cinema, grote nieuwszenders) die veelal molaire (macht)structuren volgen, zijn er met de komst van digitale apparatuur en vooral met de Web 2.0 revolutie op internet steeds meer stemmen te horen en worden er steeds meer micropercepties en moleculaire lijnen direct zichtbaar. De pragmatische analyse van al die politieke lijnen, hun gevaren en de manieren waarop ze met elkaar verknoopt raken, wordt daardoor steeds belangrijker om de complexiteit en veranderlijkheid van het concrete sociale veld van de hedendaagse (media)maatschappij te kunnen analyseren en begrijpen' (Pisters, 2009, p. 235).

\footnotetext{
132 De Commissie Dijkgraaf schrijft in 2010 in haar rapport Onderscheiden, verbinden, vernieuwen. De toekomst van het kunstonderwijs over 'duizend podia voor talent' (Commissie Dijkgraaf, 2010, p. 20). De commissie adviseerde als externe commissie op verzoek van de HBO -raad over de herstructurering van het kunstvakonderwijs.
} 
Deze bewegingen missen hun effect op instituten als theaterscholen niet. De meeste voor het theater opgeleide acteurs, actrices en performers krijgen door deze ontwikkelingen hoe dan ook vakmatig te maken met film, televisie en nieuwe media. Vanwege dit differentiërend beroepsperspectief wordt er door studenten op de Toneelacademie veel gefilmd tijdens hun opleiding en erna, terwijl dat niet zo lang geleden nog exclusief gebeurde door mensen met een specifieke filmacademieachtergrond. De domeinen waar hedendaagse filmproductie plaatsvindt worden, behalve door traditioneel opgeleide professionele filmers en de rondom hen gebruikelijke productieteams ${ }^{133}$, meer en meer bevolkt door anderen, tussen wie studenten van de Toneelacademie zich gaan begeven: amateurs, kunstenaars uit diverse disciplines, studenten van andere kunstvakken, wetenschappers en prosumenten. Gewapend met camera's en opnameapparatuur produceren zij audiovisueel materiaal. Dit betekent nog niet dat iedereen met een camera meteen filmer of documentairemaker is, net zo min als iedereen in het bezit van een vulpen of laptop ook meteen schrijver is. Bovendien werkt het feit dat internetgebruikers over de gehele wereld binnen tien dagen meer dan een eeuw aan beeldmateriaal op internet zetten, erg relativerend. ${ }^{134}$ Toch zijn er voorbeelden van relatieve outsiders als leveranciers van kwaliteit. Een sprekend voorbeeld is de Britse beeldend kunstenaar en Oscarwinnaar Steve McQueen met zijn aandachttrekkende speelfilms Hunger (2008) 135 en Twelve Years a Slave (2014) ${ }^{136}$. Filmprijzen zijn ook gegaan naar studenten van de Toneelacademie Maastricht: performancestudent Relinde de Graaff won in 2008 de eerste prijs op het Unifest Filmfestival in Madrid met haar korte film Hombre! en Anna van der Heide (in juli 2003 als theaterregisseur afgestudeerd) won in 2007 met haar MissiePoo 16 op het Nederlandse Filmfestival in Utrecht het Gouden Kalf voor de beste korte film (Heide, 2007). De eerste regel in de filmrecensie van Hunger in NRC Handelsblad luidde: 'Maken beeldend kunstenaars een ander soort films dan reguliere regisseurs?' (Bruijn, 2008). Een voor de hand liggende vraag zou in dit verband zijn: maken studenten op een theateropleiding andere films dan gewone filmregisseurs? Wat is de betekenis en de positie van deze andere, niet cinematografisch opgeleide, filmers? Het antwoord op die vragen vergt een ander onderzoek dan dit.

\footnotetext{
133 Over het algemeen zijn deze traditionele filmprofessionals in Nederland opgeleid op de Nederlandse Filmacademie te Amsterdam.

${ }^{134}$ Begin 2010 werd er elke minuut 24 uur beeldmateriaal op YouTube gezet, eind 2010 was dat al 35 uur, in 201148 uur en in 201260 uur per minuut. In het voorjaar van 2013 is dat opgelopen tot 72 uur beeldmateriaal per minuut. Het wil zeggen dat iedere seconde 1,2 uur materiaal wordt geüpload, dat betekent meer dan een eeuw aan nieuw materiaal in tien dagen (Onehourpersecond, n.d.).

${ }^{135}$ De film is gebaseerd op de waargebeurde geschiedenis van de hongerstaking van IRA-leden in de Mazegevangenis in Noord lerland in 1981.

${ }^{136}$ In 2014 won Steve McQueen een Oscar voor de beste film met zijn Twelve Years a Slave, een bioscoopfilm gebaseerd op de autobiografie van Solomon Northup uit 1853.
} 
Toekomstige jonge theaterprofessionals spelen als practice based specialisten hun rol in het transitieproces van de Toneelacademie. Er wordt meer dan ooit gefilmd, gemonteerd en geschreven aan scenario's en werken op internet is staande praktijk. Dit verschijnsel staat niet op zichzelf maar is deel van een bredere beeldtaal-gerichtheid wereldwijd. In maart 2009 schrijft Bianca Stigter in het Cultureel Supplement van het NRC Handelsblad in een artikel over een verschijnsel genaamd fan edits $^{137}$ :

'Op het web vervaagt het onderscheid tussen makers en gebruikers, tussen producenten en consumenten, tussen kunstenaars en publiek, maar nog niet zo erg dat die grenzen opgeheven kunnen worden. De middelen om kunst te maken zijn wel gedemocratiseerd. Misschien gaat film in dit opzicht meer lijken op muziek, waar thuis en in kleine kring niet alleen naar geluisterd wordt. Muziek wordt ook gespeeld, becommentarieerd, uitgevoerd. Misschien worden scenario's ooit zoiets als bladmuziek' (Stigter, 2009).

$\mathrm{Na}$ de microfoon en de camera in de jaren zeventig volgden later opnameapparatuur, montagetafels, computer, software, webcam en internet als gangbaar instrumentarium in het theateronderwijs. Alle theaterstudenten in Maastricht komen tijdens hun studie deze toepassingen tegen, evenals theoretische reflectie op de consequenties van de inzet ervan. Vooral in de combinatie van practice based reflectie en concreet artistiek onderzoek in het repetitielokaal wordt het veranderingsproces duidelijk. Docenten, lectoren en studenten geven zo in een combinatie van theorie en praktijk vorm aan het transitieproces van eenduidige vakmatige canonieke training naar een op practice as research gebaseerd zoeken naar manieren om zich te verhouden tot actuele vernieuwende esthetiek en ethiek in het theater, in de media, in performances en andere performatieve domeinen.

\section{Onderzoek en kunstpraktijk: doing-thinking in schakelmomenten}

De aandacht voor onderzoek op de Toneelacademie Maastricht sluit aan bij de opkomst in de afgelopen vijftien jaar van een discours rond onderzoek op het hbo en onderzoek in de kunsten. De gedachte erachter is dat de praktijk snel verandert en studenten daarop moeten leren inspelen; daarbij zijn verschillende vormen van onderzoek nodig.

\footnotetext{
${ }^{137}$ Vanaf 2011 loopt een onderzoek aan de Universiteit Maastricht naar narratieve fanculturen. Het wordt gefinancierd door de Nederlandse Organisatie voor Wetenschappelijk Onderzoek [NWO]. Nicolle Lamerichs wil in dit onderzoek laten zien dat er processen van canonvorming plaatsvinden in popcultuur en op andere mediaplatforms door interactief fangedrag. Op 26 maart 2014 verdedigde ze in Maastricht haar proefschrift Productive Fandom.
} 
In 1999 werden in Bologna door alle Europese ministers van Onderwijs de Bologna-akkoorden getekend. Die hielden in dat alle Europese landen zich er vanaf dat moment toe verplichtten om het Angelsaksische Bachelor-Mastersysteem (BaMasysteem) voor het hoger onderwijs in te voeren. Deze uniformering van de hogeronderwijsstructuur diende Europese studentuitwisselingen, onderwijskundige samenwerking en gemeenschappelijk onderzoek makkelijker te maken. De toenemende wisselwerking tussen het opleiden voor het uitvoerende theatervak en theoretische reflectie op de betekenis van kunst en theater, werd een van de belangrijkste gevolgen voor theateropleidingen van de invoering van het BaMasysteem. Tegelijk met de invoering ervan werden door de Nederlandse overheid met het instellen van lectoraten en kenniskringen gelden vrijgemaakt voor het faciliteren en implementeren van onderzoek in het hbo. ${ }^{138}$ Henk Borgdorff, lector onderzoek in de kunsten aan de Hogeschool van Beeldende Kunst, Muziek en Dans in Den Haag en visiting professor aan de Universiteit van Gothenburg (Zweden), beschrijft het in 2009 als volgt:

'Ook de kunstenwereld en het kunstonderwijs zijn aangetast door het onderzoeken kennisvirus. Het is niet meer voldoende het metier te beheersen, en vanuit die basis mooie objecten, voorstellingen, composities en events te creëren. Kunstenaars zijn wat tegenwoordig reflective practitioners (Donald Schön) wordt genoemd' (Borgdorff, 2009, p. 58).

Sinds de ratificatie van de Bologna-akkoorden is er ruimte voor onderzoek in het hbo, in dat kader sinds 2002 ook op de kunstenfaculteiten van Zuyd Hogeschool. Sindsdien denken alle betrokkenen op de Toneelacademie mee in het discours rond dichotomieën als woord en beeld, theater en performance, representatie en presentatie, kunstpraktijk en openbaarheid, en de toenemende aandacht voor technologie; iedereen wordt in meer of minder mate geconfronteerd met onderzoek in de kunsten. ${ }^{139} \mathrm{Er}$ is geïnvesteerd in onderzoeksprogramma's van lectoraten rond

\footnotetext{
${ }^{138}$ Op de Toneelacademie Maastricht is vanaf 2001 een dergelijk onderzoeksprogramma vormgegeven rond het begrip Nieuwe Theatraliteit. De eerste Lector Nieuwe Theatraliteit was Dr. Chiel Kattenbelt, tevens universitair hoofddocent theater, film, en televisiewetenschap aan de Universiteit Utrecht. Hij trad aan in 2002. Het lectoraat kende drie onderzoeksgroepen, te weten 'theater en openbaarheid', 'theater en technologie', en 'theater en taal'. Vanaf 2007 werd dit lectoraat gecontinueerd onder de titel Autonomie \& openbaarheid in de kunsten, onder leiding van interim lector Prof.dr.F.M.(Maarten) Doorman, die een jaar later werd opgevolgd door lector dr. Peter Peters, tevens universitair docent filosofie aan de Universiteit Maastricht. In 2013 werd Peters opgevolgd door dr. Ruth Benschop en werd er tevens een tweede kunstenlectoraat geïnstalleerd bij Zuyd Hogeschool, het Lectoraat Technology Driven Art, onder leiding van Peter Missotten.

139 Sinds 2012 is bijvoorbeeld in het auditieprogramma zowel als in het eindexamenpakket van alle acteuren performancestudenten het curriculumonderdeel Lecture Performance opgenomen. In een lecture
} 
theater en openbaarheid, en theater en technologie, in professioneel geoutilleerde digitale studentenwerkplekken, in het aantrekken van gespecialiseerde professionals uit de hedendaagse performatieve praktijk als projectleiders en stafdocenten ${ }^{140}$ en in banden met de universitaire wereld. ${ }^{141}$ Gaandeweg worden stappen gezet om basale artistieke onderzoeksvaardigheden als deelcompetenties op te nemen in de curricula van de verschillende opleidingstrajecten en er wordt studenten veel ruimte gegund om zelfstandig onderzoekstrajecten op te zetten. Hierna volgt allereerst een voorbeeld van een studentproject dat deels met onderzoeksgeld is gefinancierd. Dat het niet eenvoudig is om onderzoek een volwaardige plaats in het curriculum te geven, wordt vervolgens geïllustreerd door voorbeelden van onderzoeksprojecten die minder succesvol waren.

TNO, de Stellar Sound Show. In de loop van 2003 maakte toenmalige lector Nieuwe Theatraliteit, Chiel Kattenbelt, contact met TNO-ingenieur Gertjan Oldeman. ${ }^{142}$ TNO was geïnteresseerd in een connectie met de kunstenwereld. Op maandag 24 november 2008 vond het eerste concrete vervolg plaats. In een van de lokalen van de Academie van Bouwkunst in Maastricht kwam een deel van een mediawerkgroep van het Zuid Limburgse SIA/RAAK-project bij elkaar. ${ }^{143}$ Gasten waren twee ingenieurs van TNO, Wouter Vos en Hans van den Burgt. Vos en Van den Burgt demonstreerden die middag een trilvest met behulp van een computergestuurde helikoptervluchtsimulator. Bij TNO ontwikkelde men dit trilvest om piloten in gevechtshelikopters in moeilijke situaties een beter richtinggevoel te geven (Erp, 2007). In wat er uitziet als een zwemvest, zijn een aantal sensoren verwerkt die lijken op trilsensoren in mobiele telefoons. Door de sensoren te laten reageren op aansturingen door derden, kunnen bewegingen en richtingveranderingen die door een piloot worden uitgevoerd beïnvloed worden. Hierdoor kan hij onder moeilijke omstandigheden makkelijker gericht manoeuvreren of gemanoeuvreerd worden.

De aanwezige theaterstudenten, docenten, toenmalige lector Peter Peters en de TNO-onderzoekers namen om beurten plaats achter de joystick en het

\footnotetext{
performance wordt het resultaat van een bescheiden onderzoeksopdracht of vraagstelling in een performatieve lezing gepresenteerd aan een publiek.

${ }^{140}$ In het afgelopen decennium zijn zo structureel aangetrokken Quirine Racké en Helena Muskens (videokunstenaars), Peter Missotten (videokunstenaar en scenograaf), Ingrid Wender (performer en regisseur) en Martin Verheesen (musicus en componist).

${ }^{141}$ Deze toenadering blijkt in het algemeen uit de instelling van kunstlectoraten waarmee onderzoek wordt verankerd in het kunstvakonderwijs, uit de groeiende mogelijkheden voor kunststudenten om masterstudies te volgen in binnen- en buitenland en uit een groeiende stroom publicaties waarin het discursieve gebied tussen kunst en wetenschap belicht wordt.

${ }^{142}$ TNO = Nederlandse organisatie voor Toegepast Natuurwetenschappelijk Onderzoek.

${ }^{143}$ SIA/RAAK = Stichting Innovatieve Alliantie/ Regionale Aandacht Actieve Kenniscirculatie.
} 
computerscherm. Verschillende opties voor het inzetten van het trilvest passeerden de revue. TNO dacht daarbij aan blinden, slechthorenden en andere gehandicapten. De theatermensen dachten vrijwel meteen aan vertalingen van publieksreacties, aan onderlinge signalen tussen performers en aan het beïnvloeden van de handeling van performers door derden. Er werden afspraken gemaakt voor theorie- en conceptontwikkeling en er volgde een driedaagse workshop met performancestudenten van de Toneelacademie in mei 2009. De studenten sloegen tijdens de workshop vrijuit aan het experimenteren. Zou een geblinddoekt iemand door middel van trilcommunicatie in combinatie met een keyboard en een computer duidelijk gemaakt kunnen worden wat hij op een schoolbord moest tekenen? Welke toepassingen waren denkbaar in een situatie van een aantal performers tegenover een kleine publieksgroep? Was een aantal mensen uitgerust met een trilvest gelijktijdig door een derde aan te sturen zodat een min of meer synchrone choreografie ontstond?

Een van de studenten was Iris van der Ende. Tussen de workshop in 2009 en haar afstuderen in juni 2012 heeft ze zich in Maastricht een onderzoeksgerichtheid eigen gemaakt die toont dat de culturen van podiumkunst en wetenschap in een vroeg stadium verweven kunnen raken. Tijdens de experimenten met het trilvest stelde projectleider Sybrand van der Werf haar terloops de vraag: wist je dat sterren geluid maken? Hij voegde eraan toe dat wetenschappers en componisten daar onderzoek naar deden. Deze vraag liet Van der Ende, harpiste van huis uit, niet meer los. In de jaren die volgden, legde ze contact met asteroseismologen in België, Nederland en Hongarije. ${ }^{144}$ Ze vertrok voor een tijdje naar Boedapest om te spreken en te werken met professor Zoltán Kolláth. In de loop van 2011 schreef ze:

'Een half jaar later zit ik in het vliegtuig naar Hongarije. Ik keek uit het vliegtuigraampje en ik vroeg me af of het waar was wat ik in mijn concept had geschreven: Ik ga er van uit dat als ik een maand in deze wetenschappelijke materie duik, in samenwerking met een specialist op dit gebied, dit concept zal verrijken en veranderen' (Ende, 2012, p. 22).

Eenmaal terug in Nederland sleutelde ze met de ICT-specialist van de Toneelacademie, Hans Lasschuit, aan interfaces voor haar harp en aan gebruiksvriendelijke varianten van laserapparatuur. Na een stage bij het Amsterdamse instituut Studio voor Elektronische Instrumentale Muziek (STEIM) mocht ze daar terugkomen voor een werkperiode in een internationale groep van componisten en specialisten op het

\footnotetext{
${ }^{144}$ Respectievelijk Prof. dr. Conny Aerts van de KU Leuven, Prof. dr. Zoltán Kolláth van de Hungarian Academy of Sciences in Boedapest en dr. Saskia Hekker van de Universiteit van Amsterdam. Asteroseismologen houden zich bezig met het analyseren van de structuur van pulserende sterren.
} 
gebied van elektronische muziek. Dit alles leidde gaandeweg tot een reeks van experimenten, soms uitgevoerd voor publiek op de Toneelacademie, een keer op de sterrenwacht in Heerlen en soms in een laboratoriumopstelling. Het resulteerde in de productie en uitvoering van een professioneel gefinancierde, nachtelijke voorstelling op het Oerolfestival op Terschelling in de zomer van 2011, de Stellar Sound Show. In deze show speelt ze harp en verweeft ze de versterkte klanken van een aantal sterren al spelend met een gesproken uitleg van wat sterrengeluid is. Ze gebruikt daarbij laserstralen om voor het publiek de sterren die gehoord worden aan te wijzen. Bij sommige van de performances wordt in de randprogrammering een lezing verzorgd door de Nederlandse asteroseismoloog Saskia Hekker. Het project kreeg aandacht in de pers, asteroseimologen waren verguld door dit schakelmoment tussen hun vakgebied en de kunsten. Van der Ende stelde haar ervaringen rond deze fascinatie op schrift. Stellar Sound Show. The story behind the performance werd in eigen beheer uitgegeven als deel van haar eindexamenperformance in juni 2012.

Niet alle onderzoeksinitiatieven verliepen even rimpelloos als het project van Van der Ende. Het internationale samenwerkingsproject I'll Be Gone, uitgevoerd door theaterstudenten uit Maastricht en studenten van de bacheloropleiding van het Department of Contemporary Arts van de MMU Cheshire Manchester (Manchester Metropolitan University), leverde uiteindelijk juist voor wat betreft de gezochte samenwerking enigszins teleurstellende resultaten op. ${ }^{145}$ Het doel van het project was om de relaties tussen echt en onecht, en live en niet-live te bevragen, issues die spelen in het discours rond theater, performance en virtualiteit. I'll Be Gone, een project onder leiding van Peter Missotten, werd in 2010 weliswaar een prijswinnende voorstelling op het Internationaal Theaterscholenfestival in Amsterdam ${ }^{146}$, maar de concrete samenwerking in het artistieke onderzoek tussen projectleider, de vier Engelse en vijf Nederlandse performancestudenten en de beide faculteiten had substantieel te lijden gehad onder communicatieproblemen tussen de studenten. De verschillen in de voortrajecten en achtergronden van de studieprogramma's van de beide studentgroepen bleken te groot. Bovendien openbaarde zich een gebrek aan concrete onderzoeksvaardigheden en relevante verslaglegging bij de betrokken Nederlandse en Engelse studenten tijdens het proces. Het werkproces werd op verzoek van projectleider Missotten vanaf de start gedocumenteerd en geanalyseerd door extern waarnemer Ruth Benschop, als senior onderzoeker verbonden aan het Lectoraat Autonomie \& Openbaarheid in de Kunsten van Zuyd Hogeschool. Haar artikel

\footnotetext{
${ }^{145}$ I'll Be Gone werd uitgevoerd in het kader van het SIA/RAAK onderzoeksproject The Virtual Body. Het SIA/RAAK-fonds richt zich op het financieren van regionaal praktijkgericht onderzoek, in veel gevallen in samenwerking met Hogescholen.

${ }^{146}$ De voorstelling I'll Be Gone kreeg in juni 2010 de IT's Guest Award 2010.
} 
I'll Be Gone Again. Documenting the Virtual Body, waarin ze melding maakt van de negatieve ervaringen van een belangrijk deel van de betrokkenen, werd gepubliceerd in het kader van het Artistic Research Catalogue-project (Benschop, 2011a). ${ }^{147}$

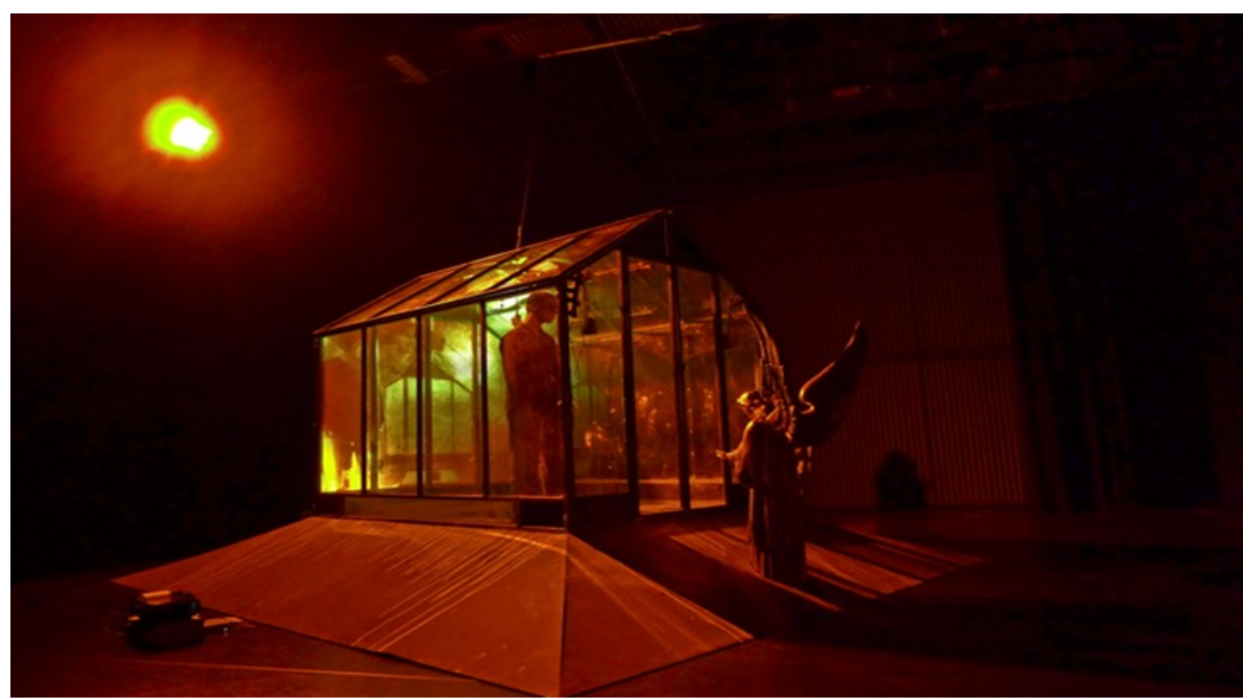

Fig. 9 I'll Be Gone (Toneelacademie Maastricht, 2010). (Foto Peter Missotten)

Interculturele transities: '....one way or another, we are all migrants' ${ }^{148}$

Transities op de theateropleidingen worden niet alleen door digitalisering en intermedialiteit gekenschetst, maar ook door verschillende gradaties en vormen van interculturaliteit. Het begrip interculturaliteit werd lange tijd vrijwel alleen in verband gedacht met interferentieprocessen tussen westerse en niet-westerse culturen. Bij het duiden van actuele theatertransities zijn ook andere interferenties van belang gebleken, zoals die tussen digitale en analoge culturen, tussen 'hoge' en 'lage' cultuur, en tussen een verticale of dieptecultuur van de traditionele canon en een horizontale of platte cultuur van de netwerksamenleving. Hierna zal ik stilstaan bij enkele implicaties van interculturaliteit op de Toneelacademie, allereerst op basis van de gebruikelijke uitleg westers en niet-westers, daarna schenk ik aandacht aan een andere intercultureel te noemen transitie-ervaring, die tussen kunst en bedrijfsleven.

Het begrip interculturaliteit in de context van westers/niet-westers past in het politieke en maatschappelijke debat rondom immigratie, integratie en de hedendaagse co-existentie van verschillende culturele leefwerelden. Paul Scheffer $(2000,2007)$

\footnotetext{
${ }^{147}$ www.researchcatalogue.net

${ }^{148}$ Nederveen Pieterse ( 2004, p. 3).
} 
veroorzaakte daarin veel reuring met zijn werk, waarin hij een multicultureel drama voorspelde door de vorming van een etnische onderklasse en pleitte voor meer nationaal besef en een dwingender beleid inzake integratie. 'We slaan onszelf op de nationale borst omdat we denken er geen te hebben. Die grenzeloze houding van Nederlanders draagt niet bij tot integratie, omdat daar achter maar al te vaak een afstandelijke en achteloze samenleving schuilgaat' (Scheffer, 2000). In De gedroomde samenleving (Schinkel, 2008), houdt de socioloog Willem Schinkel een andersoortig pleidooi. Hij verdedigt het verlaten van de gedachte van een noodzakelijke en gedwongen integratie van allochtonen in een Nederlandse samenleving. Van hem hoeft niemand ergens in te integreren, omdat dat impliceert dat sommige mensen blijkbaar ergens buiten zijn. In feite ontvouwt zich ook voor Nederlanders met ver teruggaande Nederlandse achtergronden een noodzaak om zelf te integreren in een nieuwe, voortdurend veranderende samenleving. Hij schrijft: 'Want waarom zouden het 'allochtonen' zijn die [niet geïntegreerd] zijn wanneer culturele oriëntaties verschillen?' (Schinkel, 2008, p. 59). ${ }^{149}$ Schinkel geeft aan dat autochtone Nederlanders tot nu toe formeel vrijgesteld zijn van deze integratieverplichting, omdat zij in het discours meestal gezien worden als de enige echte gemeenschap. Hij beschrijft een als oorspronkelijke Nederlands gekenmerkte sociaal-culturele eenheid, waar alles wat 'anders' is in geïntegreerd zou moeten worden. Voor veel Nederlanders is het volgens hem een angstig idee te moeten leven met iets of iemand anders, laat staan met heel veel anderen. Deze angstige houding noemt Schinkel sociale hypochondrie. Een samenleving wordt daarbij opgevat als een sociaal lichaam, allochtonen worden gezien als personen of elementen die zich buiten dat sociale lichaam bewegen. Omdat het lichaam bang is 'ziek' te worden door invloeden van buitenaf, wordt het nog moeilijker om er deel van uit te gaan maken. In plaats van bang te zijn dat een samenleving uit elkaar valt als verschillende culturen naast elkaar wonen, moet volgens Schinkel worden onderkend dat samenlevingen veranderen door de komst van migranten en dat wij, de zittende bevolking, ons net zo goed dienen aan te passen aan die veranderende omstandigheden als de nieuwkomers.

Recent onderzoek laat zien dat in een cultureel differentiërende samenleving het genereren van culturele betekenis en ervaring niet meer uitsluitend door het westerse, hoogopgeleide, blanke en mannelijke deel van de bevolking geclaimd kan worden (Jans, 2006a; Scheffer, 2007; Buikema \& Meijer, 2004). De Toneelacademie Maastricht

\footnotetext{
149 Schinkel zet overal in het boek waar hij het woord [integratie] gebruikt het woord tussen [ ]. Ik neem dat hier over in dit citaat. Hij verklaart het als volgt: 'Omdat "integratie" de kern raakt van het hedendaagse samenleven, is juist "integratie" voorwerp van een sterk gereguleerd discours. En omdat niet op voorhand duidelijk is wat "integratie" al dan niet betekent buiten de grenzen van dat discours, wil ik het vooralsnog als symbool opvatten, hetgeen ik qua schriftuur tot uitdrukking wil brengen door over [integratie] te schrijven. Dat voorkomt tenminste het vervelende gebruik van aanhalingstekens bij die term.' (Schinkel, 2008, p.12).
} 
heeft wat dit aangaat desondanks lang te boek gestaan als een voor studenten met een niet-westerse achtergrond nagenoeg onneembaar bolwerk. Dit werd in de hand gewerkt door de manier waarop in de artistieke praktijk lang werd en nog wordt omgegaan met allochtone acteurs en performers (typecasting) en door de manier waarop culturele gemeenschappen, andere dan de van oorsprong Nederlandse of westerse, moeten vechten voor een plaats in het Nederlandse canonieke culturele leven (Buikema \& Meijer, 2004; Adriaanse, Nieuwenhuis, Van Oosten \& Wijnhoud, 2006). ${ }^{150}$

Allochtone studenten op de Toneelacademie kunnen weliswaar onderscheiden worden op basis van hun familiebanden, afkomst of accent, net zoals Friezen, Limburgers, Vlamingen, Amsterdammers of Brabanders, maar voor hun opleiding is die afkomst niet relevant; iedereen wordt beoordeeld op een combinatie van talent en studieprestaties. De laatste tien jaar is er in het selectiebeleid wel op een strategische manier naar de veranderende Nederlandse demografische werkelijkheid gehandeld. De feitelijke openheid van de opleidingen aan de Toneelacademie is meer bekendgemaakt onder getalenteerde kandidaten met niet-Nederlandse achtergronden. Het bleek noodzakelijk om het beeld van een onneembaar bastion te nuanceren. Docenten verbonden aan de Toneelacademie gingen daarom zelf lesgeven in wat wel een schakelcircuit is genoemd, een netwerk van Nederlandse cursushuizen en theatervooropleidingen met veel cursisten met een niet-Nederlandse achtergrond. Afdelingscoördinator van de acteurs- en performersopleiding, en stem- en spraakdocent Yvette Fijen heeft jarenlang lesgegeven op het Amsterdamse cursushuis De Nieuw Amsterdam (DNA), afdelingscoördinator van de regieopleiding, regisseur en speldocent Aram Adriaanse is artistiek leider geweest van DNA en nauw betrokken bij de Utrechtse urban jongerentheatergroep DOX. In het verlengde hiervan is er tevens een intensief contact gemaakt met Nederlandse castingbureaus om de daar ingeschreven allochtone talenten te wijzen op kansrijke mogelijkheden om hun actieradius en draagkracht binnen het performatieve spectrum te vergroten met een bachelordiploma theater. Tijdens de auditierondes wordt er de laatste jaren op de Toneelacademie een streefcijfer gehanteerd van 25 tot 30 procent instroom van

\footnotetext{
${ }^{150}$ Dit werd recent nog door een onderzoeksproject van theaterstudent Mehrnoush Ramani rond typecasting onderstreept. In juni 2014 presenteerde zij als deel van haar examenprogramma een gedocumenteerde lecture performance, getiteld: 'Representatie van Noord Afrikaanse en middenoosterse allochtonen in de Nederlandse populaire film tussen 2001 en 2014'. Hierin wordt duidelijk dat er in 2014 nog steeds sprake is van stereotyperende casting, al dient vermeld dat er vaak sprake is van komisch bedoelde verhaallijnen met een knipoog, voor een op de grootste gemene deler gerichte markt. Of de knipoog lukt of mislukt doet echter niets af aan afkeurenswaardige gangbare automatismen van stereotypering. Rahmani zet zich actief in voor het tegengaan van deze vaak automatische stereotyperende casting van Nederlandse acteurs en actrices met niet westerse achtergronden (Rahmani, 2014).
} 
studenten met een niet-Nederlandse achtergrond (Toneelacademie, 2014). ${ }^{151}$ De studiejaren tussen 2010 en 2015 tonen in Maastricht een percentage studenten met een niet-westerse achtergrond dat schommelt tussen de 10 en de 15 procent. Als daarbij de substantiële aantallen Vlaamse, Duitse en Oost-Europese studenten worden opgeteld, wordt het streefcijfer voor studenten met een niet-Nederlandse achtergrond gehaald. ${ }^{152}$

Het feit dat in de afgelopen decennia Nederlandse acteurs en actrices met nietwesterse achtergronden wel furore maakten in soapseries, in standupcomedyprogramma's, op televisie, in de Nederlandse speelfilm en in de muziekindustrie maar niet in de gevestigde Nederlandse theaterwereld, heeft het idee versterkt dat het integratieprobleem van de typecasting vooral daar bestond. Als theaterrecensent Wilfred Takken het in maart 2009 bij de première van een nieuwe Romeo en Julia bij Het Nationaal Toneel in het NRC Handelsblad heeft over 'een kleine revolutie in het Nederlandse theater', dan heeft hij het over het feit dat een acteur met Tunesische achtergrond met zijn lichtbruine huidskleur en krulhaar nu eens niet gecast is voor een rol van gastarbeider of crimineel, maar in een hoofdrol (Takken, 2009). ${ }^{153}$ Acteur Marwan (Chico) Kenzari, toentertijd eindexamenstudent in Maastricht, speelde de rol van Romeo. Ik volg Schinkel door te stellen dat het voor de casting van de rol feitelijk niet interessant is dat Kenzari een Tunesische achtergrond heeft. Vaktechnisch is het wel interessant om te onderzoeken of op de vertolking van een hoofdrol uit het westerse toneelrepertoire de culturele achtergrond van de

\footnotetext{
151 In 2009 werd op het landelijk sectoroverleg van theaterscholen door 'Maastricht' nog gesproken over een streefpercentage van 20 procent instroom van studenten met niet-Nederlandse achtergrond (Netwerk Theater, 2009, p.10)

${ }^{152}$ Bron: Studentlijsten Studiegidsen Toneelacademie 2013-2014 en 2014-2015. Hiernaast heb ik mij mondeling laten informeren over het diversiteitsbeleid door Patricia de Kort, beleidsadviseur en kwaliteitszorgfunctionaris Toneelacademie Maastricht. De uitstroomcijfers van afgestudeerden verschillen niet substantieel van de instroomcijfers omdat er streng geselecteerd wordt aan de poort. ledereen die auditie doet en uiteindelijk wordt aangenomen, heeft een selectieprogramma doorlopen van alles bij elkaar ruim een week.

153 'In stilte voltrekt zich dit seizoen een kleine revolutie in het schouwburgtoneel. Het Nationale Toneel, bolwerk van de blanke elite, castte een Tunesische jongen en een Turks meisje in de hoofdrollen van twee klassieke toneelstukken, zonder dat hun afkomst een rol speelt in de enscenering. Dus Hedda Gabler is geen onderdrukte Turkse huisvrouw. En in "Romeo en Julia'" dat vanavond in première gaat, speelt geen etnisch conflict tussen een Arabische en een Hollandse familie. Dat klinkt normaal, maar dat is het niet. In de schouwburgen zie je voornamelijk autochtone blanke Nederlanders, zowel op het podium als in de zaal. Acteurs met een mediterrane achtergrond zijn vaak veroordeeld tot het spelen van stereotype rollen, doorgaans probleemgevallen uit de Turkse en Arabische onderklasse.' (Takken, 2009). Het Nationaal Toneel is een van de grootste Nederlandse gesubsidieerde theatergezelschappen. Deze Romeo en Julia ging op 6 maart 2009 in première in Den Haag. Acteur Marwan (Chico) Kenzari is in juli 2009 als acteur afgestudeerd aan de Toneelacademie Maastricht. Na zijn eindexamen speelde hij in diverse speelfilms en is hij van 2009 als acteur verbonden aan Toneelgroep Amsterdam.
} 
vertolker van invloed is. Het zou interessant zijn om te weten of het voor het repetitieproces of voor het publiek iets uitmaakte of Kenzari een significant andere Romeo opvoerde dan bijvoorbeeld zijn Nederlandse collega's Pierre Bokma, Fedja van Huêt, Hans Kesting of Jacob Derwig. Of een cultuurbepaald verschil in omgaan met man-vrouwverhoudingen tijdens het repetitieproces of de voorstelling schuurt met de dramaturgie of met de opvoeringstraditie in Nederland. Dan speelt Kenzari zijn eventueel impliciet cultureel ingekleurde Romeo als een van de begin-21e-eeuwse opties. Hiermee hoort zijn vertolking, op basis van een oud-Engelse toneeltekst in een twintigste-eeuwse Nederlandse vertaling, met een vroeg-21e-eeuwse NoordwestEuropese regieopvatting, met een in Maastricht opgeleide Tunesische Nederlander in de hoofdrol, in zijn geheel tot de hybridiserende Nederlands-Vlaamse theatertraditie.

Nederlanders met niet-Nederlandse achtergrond kiezen aldus, inclusief hun anders zijn, voor een bestaan binnen de Nederlandse subcultuur van het gevestigde theater. Zij hebben de gelegenheid gekregen of genomen om dat te doen. De afgelopen jaren bevolkten studenten met namen als Sadettin Kirmiziyüz, Nadia Amin, Vanja Rukavina, Achmed Akkabi, Mandela WeeWee, Nastaran Razawi Khorasani, Akwasi Owusu Ansah, Serin Utlu, Kyra Bououargane, Daria Bukvić, Sacha Janatti, Gülsüm Isleyen, Lena Sofuoglu, Elif Korkmaz, Abdullah El Baoudi, Majd Mardo, Mehrnoush Rahmani, Olaf Ait Tami, Romano Haynes, Abdelkarim el Baz, Ayisha Siddiqi, Emmanuel Ohene Boafo en Saman Amini de Toneelacademie Maastricht. De achtergronden van de studenten doen er bij de aanname steeds minder toe, wel kunnen de culturen waarin zij actief bewegen, hun studie en latere beroepspraktijk kleuren. Daarbij dient opgemerkt te worden dat het streefpercentage studenten met een niet-Nederlandse achtergrond gemeten over de gehele breedte van het opleidingsinstituut weliswaar gehaald wordt, maar dat in 2014 de regieopleiding en de performanceopleiding nog vrijwel geheel 'wit' zijn. Een toekomst als regisseur of performer wordt klaarblijkelijk door jonge kunstenaars met een niet-westerse achtergrond gezien als een minder aantrekkelijk beroepsperspectief. Een veelgehoorde verklaring is dat voor studenten met een niet-westerse achtergrond een toekomst als acteur nog wel voorstelbaar is door een aantal tot de verbeelding sprekende rolmodellen, maar dat in Nederland en Vlaanderen die rolmodellen er voor regisseurs en artistiek leiders veel minder zijn; van gekleurde alumni vernemen we dat artistiek leiders en regisseurs met niet-Nederlandse achtergrond nog steeds zeldzaam zijn. $^{154}$

\footnotetext{
154 Bij gerichte navraag in augustus 2014 over werkgelegenheid van acteurs met niet-westerse achtergrond sprak ik Toneelacademie alumnus (2012) Mandela WeeWee, acteur van Surinaamse afkomst. Hij vertelde me dat hij aangenaam verrast werd door het voelbare verschil in werken toen hij in Zuid Afrika donkere artistiek leiders van gezelschappen ontmoette.
} 
Interculturele schakelprocessen in de zin van confrontaties en dialogen beperken zich niet tot uitwisselingen tussen etnisch verschillende groeperingen, maar vinden evengoed plaats tussen 'hoge' en 'lage' culturen, tussen analoge en digitale media, tussen kunst en mode, pop, wetenschap en bedrijfsleven. Het volgende voorbeeld toont een confrontatie tussen de culturen van performancestudenten, filmproducenten en bedrijfsleven.

Een in vergelijking met de theaterwereld andersoortige artistieke praktijk, een andere cultuur zouden we kunnen zeggen, wordt gevormd door de activiteiten van commercieel communicatiebureau KesselsKramer in Amsterdam. KesselsKramer is een wereldwijd opererend bureau, opgericht door Erik Kessels en Johan Kramer. Het maakte werk voor onder meer Nike, Audi, Levi's, Hans Brinker Budget Hotel, Het Parool, Ben, bol.com, Heineken en het kledingmerk Diesel. Creatief directeur Erik Kessels won nationale en internationale reclameprijzen en heeft daarnaast verschillende kunstpublicaties en boeken op zijn naam staan, waarvan de bekendste zijn: The Instant Men, Useful Photography en Almost Every Picture. In zijn werk zijn de grenzen tussen autonome kunstwerken en het toegepaste werk van ontwerpers en reclamemakers aan het vervagen. De films, fotoseries en installaties, die niet alleen in verkoopcampagnes maar ook op exposities te zien zijn, tonen een hybride werkterrein waarin creatieve geesten hun verbeelding vormgeven.

In januari 2007 gaf Kessels een lezing over zijn werk voor een kritisch publiek van de verzamelde studenten en docenten van de Toneelacademie Maastricht. De scepsis vóór aanvang was groot. Kessels werd gezien als een vertegenwoordiger van het commerciële gilde, die zich begaf in een van de tempels van de canonieke theaterkunst. De euforie en het enthousiasme na afloop stonden diametraal tegenover deze aanvankelijke scepsis. Kessels inspireerde met ideeënrijkdom, met ontregelend beeldmateriaal en vooral met zijn stelling dat er in beginsel in zijn bedrijf geen concessies werden gedaan aan artistieke vrijheid. De klant diende geïnteresseerd te zijn in de eigenzinnigheid van de creatives van het bureau.

Ongeveer een jaar later tekenden vier performancestudenten van de Toneelacademie zich in voor een pilotproject van een aantal weken onder leiding van twee creatives van KesselsKramer. De gedachte dat artistiek creatieve studenten van de Toneelacademie waardevolle bijdragen zouden kunnen leveren aan creatieve processen op een communicatiebureau als KesselsKramer en dat andersom een dergelijk autonoom artistiek bedrijf nieuwe beroepsperspectieven zou kunnen blootleggen voor performance- of regiestudenten, prikkelden staf, docenten en studenten van de opleiding. De studenten kregen de vrije opdracht om concepten te bedenken voor het vervaardigen van korte filmpjes voor een imagocampagne voor de Toneelacademie Maastricht. De filmpjes zouden uiteindelijk op YouTube of via andere manieren in de publieke ruimte zichtbaar kunnen worden. Het idee achter de 
campagne was, behalve een test voor mogelijke samenwerking, dat het imago van de Toneelacademie Maastricht, innovatieve bewegingen ten spijt, vrijwel uitsluitend opgehangen bleef aan de kwaliteit van traditioneel opgeleide toneelacteurs. De opleiding beschouwde het als een omissie dat curriculumaanpassingen tegen de achtergrond van een snel veranderend beroepsperspectief voor startende theaterprofessionals, niet de bekendheid kregen die ze in de ogen van betrokkenen verdienden.

De fase van het daadwerkelijk filmen leidde, door diametraal tegenover elkaar staande visies op het produceren van beeldmateriaal, tot een botsing van culturen. De filmproducenten die door het bureau waren ingehuurd, waren mensen met een filmacademische achtergrond en hiërarchische opvattingen over regie, cameravoering, werken op $16 \mathrm{~mm}$-film, met aparte geluidsmensen, met vaktechnisch opgeleide cameramensen, etc. Het filmproductieproces door studenten van de Toneelacademie is van een totaal andere structuur. Zij zijn daarnaast opgevoed als digitale prosumenten, als amateurproducenten in een met apparatuur verzadigde gemediatiseerde samenleving. Beelden die ze produceren zijn opgebouwd met inzichten en vaardigheden die dicht aanzitten tegen een meer eigentijdse open dramaturgie; zij behandelen bovendien veel beeldmateriaal intuïtief. In de pilot dirigeerden de professionele filmproducenten het daadwerkelijke maakproces. Slechts één van de veertig conceptideeën van de studenten werd door hen bruikbaar gevonden. Ook beschouwden zij de studenten in de eerste plaats als in te zetten acteurs omdat ze van de Toneelacademie kwamen, terwijl de studenten zelf, de staf van de performanceopleiding en ook de creatives van KesselsKramer de studenten zagen als aankomende creatives, verantwoordelijken voor de gehele artistieke prestatie.

Dit project vond plaats in de loop van 2007 en 2008. Inmiddels is de opleiding ervan doordrongen dat dit soort fricties van alle tijden is, dat interculturele schakelprocessen deze schurende zoekprocessen en dialogen in zich dragen. In Maastricht streeft men ernaar om studenten tijdens hun studie daarmee te confronteren; ze moeten erop voorbereid zijn dat ze terecht kunnen komen in praktijken waar een andere esthetiek gehanteerd wordt dan die waar ze kennis van genomen hebben, waar andere opvattingen gehuldigd worden dan die welke gangbaar zijn in hun eigen moedercultuur. Met andere woorden, reflectie op interculturele schakelprocessen en de fricties die daarbij horen, is deel gaan uitmaken van de onderwijsinhoud. Daarbij hoort ook de confrontatie met een in toenemende mate internationale culturele context als werkveld voor de kunstenaar van de 21 e eeuw. 


\section{Internationale oriëntatie}

Door de implementatie van een veel minder taalgebonden theateresthetiek (Lehmann, 1999), door de interdisciplinaire verbreiding van wat Fischer-Lichte noemde de transformative power of performance (Fischer-Lichte, 2008) en door de wereldwijde digitale netwerkconnectiviteit, is het theater en zijn daarmee ook de theateropleidingen, veel meer dan voorheen internationaal georiënteerd. Voor hedendaagse theaterstudenten is een uitsluitend nationaal vakperspectief niet meer zaligmakend; zij zoeken hun inspiratie, bronnenmateriaal en afzetgebied vaak op Europese of op mondiale schaal. Koppelbare modules uit een gemengde interculturele netwerkcontext worden bestudeerd, verwerkt en weer afgezet op wereldmarkten, waarvoor de eerste contacten vaak gelegd worden op festivals en congressen. Voorheen werd door de Toneelacademie weliswaar ook internationaal uitgewisseld, maar dat ging vooral om uitwisselingen tussen min of meer gelijkgestemde zusterfaculteiten binnen een traditionele theaterdiscipline. De Toneelacademie heeft in die zin nog steeds onderwijscontacten met theateropleidingen en -gezelschappen in Berlijn, München, Londen, Manchester, Zurich, St. Petersburg, Lausanne, Essen, New York, Brussel, Monaco, Chicago, op Curaçao en in Zuid-Afrika. Meestal lopen zulke contacten via directie, staf en docenten. Eerdere voorbeelden in deze gevalstudie tonen dat uitwisselingen en contacten hiernaast ook steeds vaker direct via de studenten en door hen geïnitieerde projecten lopen.

Sinds een aantal jaren vormt voor alle studenten van de dagopleidingen van de Toneelacademie het Globeproject een vast onderdeel van hun curriculum. ${ }^{155}$ Individueel of in kleine studentgroepen wordt naar bronnenmateriaal gezocht in de buitenwereld en bij voorkeur in het buitenland. Studenten hebben in de afgelopen jaren werkbezoeken gebracht aan Korea, Japan, India, Zuid Afrika, Frankrijk, de Gazastrook, de Verenigde Staten, Schotland, China, Thailand, Indonesië, België, Duitsland, Denemarken en diverse andere Europese landen. Ze leggen contacten met geestverwanten, zijn betrokken bij kunstprojecten of bij sociaal-maatschappelijke projecten. Het Globeproject weerspiegelt voor alle studenten een groeiend internationalisme van de kunstenpraktijk. ${ }^{156}$

Ter adstructie van de manier waarop vaker direct naar bronnen gezocht wordt en studenten voorbereid worden om op wereldschaal na te denken over mogelijke

\footnotetext{
${ }^{155}$ Het oorspronkelijke idee voor deze later in het curriculum vastgelegde wereldwijde exploratieopdracht stamt van Hans Münstermann, voormalig dramaturgiedocent aan de Toneelacademie.

${ }^{156}$ Tijdens de Globeperiode (jaarlijks in maart en april) worden studenten door de opleiding en door hun mentoren gestimuleerd om bij voorkeur letterlijk de wereld in te trekken. Dat kan variëren van asielzoekerscentra in Nederland tot theater- of filmprojecten waar ook ter wereld. Het idee is dat student meer 'opgeladen' terugkeren.
} 
artistieke praktijken, zal ik hierna twee voorbeelden schetsen van het gebruik van ander dan het voor de hand liggende canonieke theaterrepertoire in een internationale context.

In 2008 begeleidde performancedocent Peter Missotten een project dat begon met een concept voor een politiek geladen voorstelling over waterboarding en rechts Amerika. Het project resulteerde in de voorstelling Congo Blue (2008), een beeldende performance over de relatie tussen ultrarechts in de VS, religiositeit en het buitenlandbeleid onder George Bush. De titel is de naam van een kleurenfilter die heel weinig licht doorlaat. Het gebruik van die filter schiep in de voorstelling een sfeer waarin spelers zowel als toeschouwers erg hun best moesten doen om te zien wat er eigenlijk gebeurde. De makers verwijzen ermee naar het duistere gebied dat zij tijdens hun researchperiode afgraasden om materiaal te verzamelen. De performance werd in het voorjaar van 2008 uitgevoerd op de Toneelacademie Maastricht door twee performancestudenten ${ }^{157}$ en twee acteurstudenten. ${ }^{158}$ In de zomer daaropvolgend werd zij hernomen in Villeneuve lez Avignon in de randprogrammering van het Theater Festival Avignon. De uitvoering in Avignon was onderdeel van een studiebijeenkomst van de werkgroep intermedialiteit van de International Federation for Theatre Research (IFTR).

In Congo Blue zagen we schetsmatig gestileerde scènes in het halfdonker rond riten en bezweringen die verwezen naar christelijke wereldbeelden. Er werd Engels gesproken, soms afgewisseld met gezongen fragmenten. De muziek werd door de studenten zelf gecomponeerd in combinatie met het gebruik van fragmenten van Sjostakovitch. De teksten verwezen naar Bijbels materiaal maar vormden geen coherent verhaal. Alle teksten werden van sites van rechtsreligieuze groeperingen in de VS gehaald, zoals die van de Ku Klux Klan, en van biechtsites. In de voorstelling was sprake van een grotendeels onzichtbaar personage, dat tot het publiek en tot de zichtbare figuren sprak via een kleine beeldintercom. Af en toe verscheen dit personage op de speelvloer en deed zich voor als verpersoonlijking van Het Kwaad. De manier waarop dit kwaad zich manifesteerde, deed sterk denken aan sequenties uit films van David Lynch en aan oudere beelden uit films als The exorcist van William Friedkin uit 1973. De voorstelling culmineerde in een traag vormgegeven scène van een zeer realistisch gespeelde waterboarding, die rechtstreeks in verband werd gebracht met het christelijke doopritueel: Amerikanen 'dopen' hun vijanden om ze tot het ware wereldbeeld te brengen. Voorts zat de voorstelling vol met technologische gadgets, zoals indringend gebruik van laserstralen. ${ }^{159}$

\footnotetext{
${ }^{157}$ Benjamin Moen en Joost Maaskant.

${ }^{158}$ Krisjan Schellingerhout en Bram van der Kelen

159 Interview met Benjamin Moen op woensdag 13 mei 2009, Maastricht.
} 
De hierna volgende teksten uit de voorstelling komen van een Amerikaanse site die functioneert als een digitale biechtstoel. De performers geven geen personages vorm, ze spelen archetypische grootheden in Amerikaanse familieomstandigheden. De flarden van een internetbiecht door een Amerikaanse vrouw worden door performer Benjamin Moen, die een archetype van een zoon speelt, fluisterend uitgesproken.

Een zoon:

I masturbate to Edward Scissor hands. Not Johnny Depp, Edward Scissor hands.

Een zoon:

I want to seduce my boss' second son. He's nine years younger than me and I am happily married, but he is the puppy-cutest ugly-sexy little thing. And he's shorter than I am. But he worships my music knowledge and I always make him play lists whenever he comes into the office and I love how he looks up to me. I wish I could see those worshipful berber eyes gazing up at me from underneath my spread thighs. The more my boss rides my ass, the worse I want to make his son my bitch.

Een zoon:

I'm going straight to jail.

Een zoon:

When my husband isn't home and I'm sick of Edward Scissor hands, I put in Joy Division's and Interpol's and masturbate slowly and completely as they repeat. It's the best sex music, trust me. I like this site. Lots of crazy kids out there, huh?

Door middel van het uitspreken van deze teksten gaf Moen een beeld van vunzige kamertjes van waaruit dit soort gedachten dag in dag uit de wereld in wordt gestuurd. De rol van een archetypische moeder werd gespeeld door acteur Krisjan Schellingerhout. Zijn/haar teksten waren eveneens afkomstig van internet maar ook uit Schopenhauers misogyne essay On Women. ${ }^{160}$ Er werd tevens een tekst gebruikt van de site van de Ku Klux Klan (KKK), uitgesproken door een niet nader bepaald wezen, archetypisch voor het kwaad of de duivel. De tekst ging over een jongetje dat van zijn moeder zijn kamer moest opruimen. In plaats van op te ruimen schoof hij al zijn troep onder het tapijt, waarna hij buiten ging spelen. Op de KKK-site maakt de schrijver van de tekst de vergelijking tussen de troep onder het tapijt en alle allochtonen, homoseksuelen en linkse politici die volgens de KKK al veel te lang genegeerd worden en nu ook maar eens goed moeten worden opgeruimd.

In Avignon vond het internationale gezelschap van de intermediality group de voorstelling opmerkelijk door de thematiek, de professionele uitvoering en het feit dat

160

Oorspronkelijk verschenen in: Schopenhauer, A. (1851). Parerga und Paralipomena. Leipzig 
tweedejaarsstudenten de voorstelling productioneel voorbereidden, er materiaalonderzoek voor hadden gedaan, zelf dramaturgische keuzes hadden gemaakt, de voorstelling zelf opbouwden met de vereiste technologische knowhow, haar uitvoerden en er ook nog zinnig over konden napraten. In een dergelijk project wordt er internationaal geschakeld; in dit geval ging de voorstelling over een actuele wereldwijde problematiek, uitgevoerd in een niet-Nederlandse context, met dramaturgische middelen die meer van doen hebben met een universele beeldcultuur dan met een literair dramatische traditie en beschouwd werden door een groep wetenschappers die reflectieve feedback gaven.

Een ander voorbeeld van internationalisering komt voort uit de werkgroepenreeks mapping performance, onderdeel van het tweedejaars curriculum van alle studenten. In deze werkgroepenreeks worden diverse internationale performancepraktijken door studenten geanalyseerd op artistieke werking, aard van de bedrijfsvoering, bronnenmateriaal en publieksbereik. Performancestudent Dennis Vanderbroeck legde via deze werkgroepen al vroeg in zijn studie contact met de Deense, internationaal opererende kunstenaar, performer en mode-icoon Henrik Vibskov. Vanderbroeck was gefascineerd door diens modeshows als performances. Vipskov en zijn staf waren geïntrigeerd door de belangstelling van een theaterstudent uit Nederland en lieten hem naar Kopenhagen komen. Vanderbroeck had vervolgens een constitutief aandeel in het vormgeven van een nieuwe show van Vibskov. In het voortraject voor deze show werd Vibskov door het Louisiana Museum voor Moderne Kunst in Humlebaek gevraagd om een muzikale performance te maken. In die periode kreeg Vanderbroeck contact met hem. Na deze verkennende ervaringen rond de totstandkoming van de muziekperformance in het museum mocht hij in 2011 samen met een andere stagiaire de catwalk/performance ontwerpen voor de nieuwe Vibskovshow, The Shrink-wrap Spectacular (2012). ${ }^{161}$

\footnotetext{
161 De show, The Shrink-wrap Spectacular, ging op 19 januari 2012 in Parijs in première en werd op 1 februari 2012 getoond in Kopenhagen. Vanderbroeck beschreef zijn ervaringen in The Shrink-wrap adventure, how theatre becomes fashion (2012).
} 


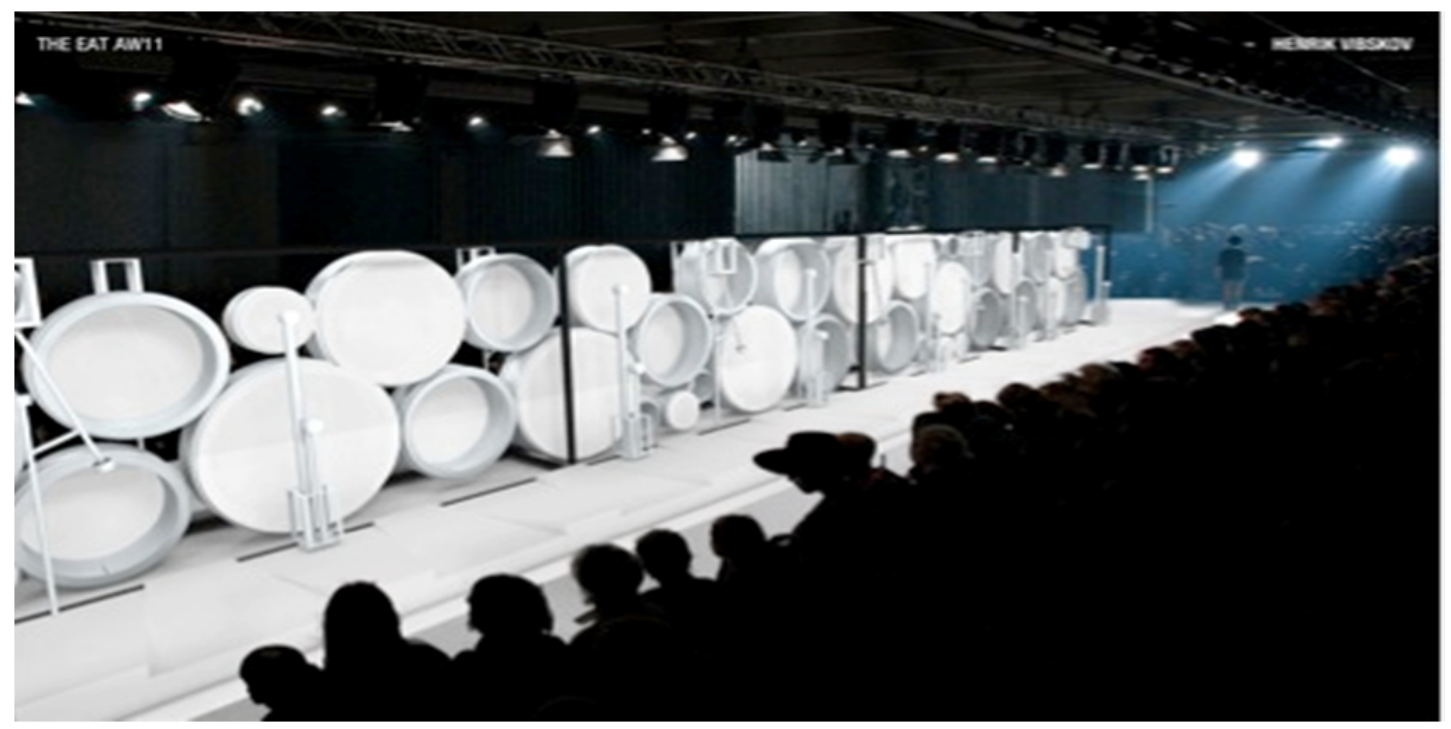

Fig. 10 Vanderbroecks virtueel ontwerp van de catwalk voor The Shrink-wrap Spectacular (Vanderbroeck, 2011)

$\mathrm{Na}$ zijn afstuderen in Maastricht in juli 2013 vervolgde Vanderbroeck zijn studie met een master aan het Central St. Martins College of Art and Design in London. In het werk van Vanderbroeck raken de culturen van een Nederlandse theateropleiding, het internationale modewereldcircuit, de wereld van de fotografie en van het toegepast vormgeven elkaar. Als we culturen breder interpreteren dan de dichotomie westers versus niet-westers, dan kunnen we hier ook spreken van interculturele transities.

Deze praktijken van het omgaan met bronnen, met een internationale context en met actualiteit en engagement is voor veel theater- en performancestudenten standaard geworden. Congo Blue en The Shrink-wrap Spectacular waren niet nationaal of regionaal canoniek cultureel bepaald en hadden kenmerken in zich van Lehmanns nieuwe theateresthetiek zowel als elementen van het performatieve. Een voorstelling als Congo Blue is daarnaast wellicht te beschouwen als Werkteater revisited: het materiaal wordt rechtstreeks aan de maatschappelijke werkelijkheid ontleend zonder het filter van de literair dramatische taal en traditie. Waar het Werkteater in de jaren zeventig onderzoek deed in de Nederlandse psychiatrie, in volksbuurten of in het gevangeniswezen om de tijd te bevragen, zo laten geëngageerde theaterkunstenaars zich vandaag de dag inspireren door wereldwijd beschikbaar bronnenmateriaal en trachten ze zich eveneens te verhouden tot de politieke, economische en culturele actualiteit. 


\subsection{De Toneelacademie en de veranderende praktijk van het theateronderwijs}

De vraag voor theateropleidingen is niet of maar hoe ze zich tot veranderende artistieke praktijken kunnen verhouden. Zij verhouden zich traditiegetrouw tot een verticale of dieptecultuur, die gekenmerkt werd door canoniek repertoire, door het concept van bildung en door cultuurfilosofische en dramaturgische reflectie. Daarnaast is het in de actualiteit van de netwerksamenleving noodzakelijk geworden om zich tevens te verhouden tot een horizontale netwerkcultuur, gekenmerkt door snelheid, veelheid, connectiviteit, non-hiërarchie, modulair denken en flexibiliteit. Ik verbind dit proces van differentiatie van theater-, performance- en mediapraktijken met de vluchtwegen en de betekenisloze breuken uit het rizomatische begrippenapparaat van Deleuze en Guattari (Deleuze \& Guattari, 2007). Dit uitvoerige grensverkeer tussen westerse en niet-westerse kunst, tussen kunst en samenleving en tussen kunst en wetenschap (Peters, 2009) ${ }^{162}$ en de uitwisselingen tussen individuen, gemeenschappen, culturele invloedssferen, echte en metaforische talen van cultuursystemen heeft zich in Nederland en Vlaanderen kunnen vormen in de emancipatoir gekleurde periode van de afgelopen 45 jaar. Het leverde en levert discussie en soms ook strijd op. In de beste gevallen kritische reflectie, wereldwijd begrepen vormen van communicatie en esthetische beleving. Het verloop van dit discours rond het ontkennen of juist onderkennen van deze rizomatische samenhang raakt theateropleidingen en heeft consequenties voor het formuleren van curricula en bodies of knowledge. In deze paragraaf zal ik allereerst aandacht schenken aan een aantal studies en documenten waarin ingegaan wordt op veranderingen in de theaterpraktijk met gevolgen voor de inrichting van theateropleidingen. Tegen die achtergrond analyseer ik daarna de veranderende positie en de werking van de Toneelacademie Maastricht.

\section{Van acteur en regisseur naar theatermaker en performer}

$\mathrm{Er}$ is in Nederland en Vlaanderen vanuit verschillende invalshoeken over acteren geschreven en de ene publicatie raakt de opleidingen directer dan de andere. Zo schreef Howard Dodemont een feitelijk, historisch overzicht van gevestigde opleidingsinstituten voor het acteeronderwijs in Nederland (Dodemont, 1998); Elly Konijn schreef een psychologische studie over de manier waarop acteurs emoties spelen (Konijn, 1994); Anja Krans besteedde kort aandacht aan de opleidingen in haar studie over hedendaags theater (Krans, 2005, p. 186); er zijn spelmethodes geschreven door voormalig Werkteater-acteurs Yolande Bertsch (Bertsch \& Filz, 2003) en Helmert

\footnotetext{
${ }^{162}$ Inaugurale rede bij de aanvaarding van het Lectoraat Autonomie en openbaarheid in de kunsten aan de Zuyd Hogeschool te Maastricht, uitgesproken door Peter Peters op 15 april 2009.
} 
Woudenberg (Woudenberg, 1999) die hun weg gevonden hebben naar de opleidingen. Deze studies en methodes gaan vooral in op het acteren als ambacht, ze besteden weinig aandacht aan veranderingen in opleidingscurricula onder invloed van een veranderende kunstenpraktijk en culturele context.

In haar artikel over het ontstaan van de mimeschool in Amsterdam geeft Janny Donker een schets van Nederlandse theateronderwijs in de jaren zestig. Ze signaleert de eerste tekenen van op handen zijnde vernieuwingen (Donker, 1996). Aanvankelijk werden jonge mensen op de nieuwe naoorlogse theateropleidingen opgeleid om terecht te komen bij een handvol gesubsidieerde Nederlandse teksttoneelgezelschappen. Al in het midden van de jaren zestig ontstonden scheuren in het louter in teksttoneeltermen denken in de gebruikelijke acteurstraining (Donker, 1996, p. 731). In 1965 opende Frits Vogels zijn School voor Bewegingstheater in Amsterdam. Hij verving demonstratief het woord mime door bewegingstheater om zich daarmee zowel af te zetten tegen het 'praattheater' als tegen het gangbare vereenzelvigen van mime met pantomime. De klassieke acteurstrainingen in die tijd waren figuratief te noemen, het programma van de nieuwe school voor bewegingstheater was gebaseerd op abstractie. Naast de bestaande opleidingen was er plaats voor een opleiding waar niet de interpretatie van dramaturgische concepten centraal stond maar het leren kennen en gebruiken van het lichaam. De nadruk lag op onderzoek naar de mogelijkheden om er voorstellingen mee te componeren (Donker, 1996, p. 132).

Een jaar later treedt Jan Kassies aan als nieuwe directeur van de Amsterdamse Toneelschool. ${ }^{163}$ Een van zijn eerste daden bestond eruit dat hij alle studenten en docenten een sleutel gaf van het gebouw aan de Marnixstraat. Kort daarna hing hij op de deuren van alle klaslokalen briefjes met 'Waarom?'; het was een provocerende uitdaging om studenten en docenten te laten nadenken over hun motivatie om toneel te gaan maken en over de rol van kunst en theater in het algemeen (Buijs, 1996). ${ }^{164}$

De effecten die vijftien jaren onderzoekstheater vanaf het begin van de jaren zeventig hadden op het vakmanschap van de acteur en dientengevolge op het opleiden van acteurs, kregen vanaf het begin van de jaren negentig onder meer hun beslag in een veranderende terminologie bij het spreken over het vak van acteren en regisseren. In Europa is de viertalige publicatiereeks Theaterschrift daarbij van belang

\footnotetext{
163 Jan Kassies (1920-1995) was naast theaterschooldirecteur ook publicist, tweeëntwintig jaar (1970-1992) bezielend leidsman van het Instituut voor Theateronderzoek, lid van de Kunstenaarsfederatie, van de Raad voor de Kunst, bestuurder bij de VPRO en bij het Stimuleringsfonds Nederlandse Culturele Omroepproducties en lid van de Eerste Kamer. Kassies was zijn hele leven actief in het spanningsveld tussen cultuur en politiek.

${ }^{164}$ Tekenend was dat degenen die de eerste tomaten naar het toneel van de Amsterdamse schouwburg gooiden op 9 oktober 1969, Lien Heyting en Ernst Katz, tweedejaars regiestudenten waren van de Amsterdamse Toneelschool (Heinink, 1994).
} 
geweest. ${ }^{165}$ In een van de eerste nummers schrijft hoofdredactrice Marianne van Kerkhoven een richtinggevend artikel over het veranderende acteren: 'Niet meer spelen, maar gespeeld worden. Bedenkingen omtrent het acteren vandaag' (Kerkhoven, 2002, pp. 81-94). Wanneer die andere manier van acteren ingang vond, is niet met zekerheid te zeggen volgens Van Kerkhoven, ze houdt het op begin jaren tachtig, met voorbeelden in het werk van Jan Decorte, de jonge Ivo van Hove, Jan Fabre, Jan Lauwers, Gerardjan Rijnders, Jan Joris Lamers, Anne Teresa De Keersmaeker en anderen. Kenmerkend is dat acteurs zich nauwelijks nog bekommerden om wat ze 'uiterlijke kenmerken' noemt: fysieke gelijkenis tussen personage en acteur doen er niet meer toe; kostuums worden gereduceerd tot aanduidingen; grime ontbreekt; mannen spelen vrouwenrollen en andersom, jong speelt oud en andersom; opkomen of afgaan als begin en eind van een scene wordt nauwelijks nog gerespecteerd; een tekst kan door verschillende acteurs verbrokkeld worden uitgesproken en het onderscheid tussen hoofd- en bijrollen is nauwelijks nog evident.

Van Kerkhoven geeft in dit artikel in 1991 al aan wat Lehmann later zal uitwerken als een van de belangrijkste kenmerken van het postdramatische theater, het afnemen van de dominantie die toneeltekst in de dramatische traditie tot dan toe had (Kerkhoven, 2002, p. 85). Er diende zich volgens Van Kerkhoven een fundamenteel nieuwe theaterpraktijk aan die gevolgen had voor het technisch kunnen van de acteur en voor de manier waarop hij vakmatig opgeleid wordt: 'Het personage 'verdwijnt' bijna...' (Kerkhoven, 2002, p. 86). Ze concludeerde dat de acteur steeds meer een autonome kunstenaar werd met voorstelbare gevolgen voor de samenstelling van ensembles, en dat abstractie zijn intrede deed in het theater als tegenkleur van het gangbare nabootsen van de werkelijkheid (Kerkhoven, 2002, pp. 91-92). Aan het eind van haar artikel zegt Van Kerkhoven dat ze niet toegekomen is aan het uitwerken van de ideeën over deze vormen van het acteren in relatie tot de acteeropleiding. Ze stelt dat deze acteervormen echter om een eigen benadering vragen voor theateropleidingen en het verwerven van de benodigde technieken (Kerkhoven, 2002, p. 93). Ook Lehmann heeft in zijn Postdramatisches Theater niet of nauwelijks geschreven over de implicaties van het veranderende acteren voor het opleiden van acteurs of andere performatieve professionals. Wél heeft hij van 1981 tot 1987 meegewerkt aan het vormgeven van de nieuwe studierichting Angewandte Theaterwissenschaft aan de Justus Liebig Universiteit in Giessen. Hier gaat het echter om een theoretische leergang en niet in de eerste plaats om een beroepsgerichte training van uitvoerende theaterprofessionals. ${ }^{166}$

\footnotetext{
${ }^{165}$ De rol van Theatertijdschrift in het theaterdiscours is in hoofdstuk 1 aan de orde geweest.

${ }^{166}$ In de loop der jaren zijn er overigens wel alumni van Giessen in de Europese theaterpraktijk terechtgekomen (Rimini Protokoll, She She Pop). Zij worden in Duitsland tot het freies Theater gerekend, een theaterdomein min of meer buiten de officiële Duitse theatertraditie van de stadstheaters.
} 
Eind jaren negentig is alom evident dat er iets moet veranderen in het theateronderwijs. De publicatie van Lehmanns boek over het postdramatische theater valt samen met het uitkomen van een landelijk rapport over het kunstvakonderwijs in Nederland en met de nakende invoering van het Europees Bachelor-Mastersysteem voor het hoger onderwijs. Toenmalig staatssecretaris van Onderwijs, Cultuur en Wetenschappen, Aad Nuis, riep in 1997 een onafhankelijke en tijdelijke Projectorganisatie Kunstvakonderwijs in het leven om een plan te ontwerpen voor de noodzakelijk geachte herstructurering van het kunstvakonderwijs. De projectorganisatie werd bijgestaan door experts uit het werkveld en uit de HBO-raad. De gehele operatie duurde van september 1997 tot de publicatie van het rapport Beroep Kunstenaar: voorstellen voor inhoud en organisatie van het kunstonderwijs in Nederland in mei 1999 (Projectorganisatie Kunstvakonderwijs, 1999). In het deelrapport Profiel van de sector Theater/Drama. Beroepsprofielen en startkwalificaties (Mostert \& Van Bakelen, 1999) zijn tendensen zoals beschreven door Van Kerkhoven en later door Lehmann terug te vinden: de groeiende discrepantie tussen het canonieke theater van het westerse dramatische repertoire en de grote variëteit aan mengvormen van genres in producties waarin het onderscheid tussen auteur, acteur en regisseur meer vloeiend is. Hoewel dit een ruime notie is van wat theater met een afnemend belang van 'taal als artificieel en retorisch toneelmiddel' kan zijn (Mostert \& Van Bakelen, 1999, p. 74), spreekt uit de rest van de tekst van het beroepsprofiel van de theatermaker vooral nog een tekstgeoriënteerdheid met incidentele verwijzingen naar de toenemende abstractie en de onthiërarchisering van theatrale middelen en naar het groeiend belang van media.

Ontwikkelingen die Mostert en Van Bakelen signaleren, worden onderverdeeld in algemene ontwikkelingen in de samenleving en ontwikkelingen in de theaterpraktijk. In de samenleving constateren ze toenemende multiculturaliteit, culturele internationalisering met uitzondering van teksttoneel en kleinkunst ${ }^{167}$, multidisciplinariteit, waarbij theater sterker dan voorheen een zaak van combined arts genoemd wordt, nieuwe media die in alle beroepspraktijken binnendringen en tot slotte wordt de marktwerking genoemd als toenemend van invloed. Specifieke ontwikkelingen in de theatersector zijn volgens de auteurs: het toenemende belang van cultureel ondernemerschap; het feit dat er steeds vaker buiten de reguliere sector theater gemaakt wordt; de inhoud van theaterproducties is vaak geëngageerd, maar de deelname aan het maatschappelijke discours door theaterkunstenaars lijkt af te nemen; er groeit een diversiteit van aanbod; grenzen tussen acteur, regisseur en

\footnotetext{
${ }^{167}$ Anno 2015 is tegen de achtergrond van deze opmerking uit 1999 het internationale succes van teksttheaterregisseurs als Ivo van Hove en Johan Simons, van het Nederlands jeugdtheater, en van bijvoorbeeld een cabaretier als Hans Teeuwen in Groot Brittannië, opmerkelijk.
} 
auteur vervagen; grenzen tussen theatergenres vervagen; veel theaterkunstenaars zijn steeds vaker ook actief in de film- en televisiewereld.

In Zicht op kwaliteit, de reactie van het Ministerie van OCW op het rapport, worden de meeste conclusies en aanbevelingen per sector overgenomen. Voor wat betreft de theateropleidingen is een conclusie dat de theatermaker centraal komt te staan als hoofdcategorie, waarmee het onderscheid tussen acteur en regisseur in de Nederlandse theaterpraktijk langzaam maar zeker vervaagde (Ministerie van OCW, 1999a, p.9). De uitwerking van aanbevelingen van het eindrapport Beroep Kunstenaar (Projectorganisatie Kunstvakonderwijs, 1999) en de reactie erop van het ministerie, anders dan in de zin van meningsvorming, is relatief gering geweest omdat de gehele hogeronderwijssector luttele jaren later in zijn totaliteit op de schop ging door de invoering van het Bachelor-Mastersysteem.

Per 1 september 2002 werden landelijk nieuwe uitstroomprofielen en bijbehorende opleidingsprofielen voor de bachelorfase van de Opleiding Theater van kracht (HBO-raad, 2003, p. 22). De uitstroomprofielen werden gebaseerd op het onderscheid tussen uitvoerend (acteur) en scheppend kunstenaar (theatermaker) en ze waren bindend voor de hogescholen die theateropleidingen aanboden. Landelijk werden tien onderliggende competenties uitgewerkt met bijbehorende opleidingskwalificaties (HBO-raad, 2003, p. 23). ${ }^{168}$ De invulling en uitvoering op het niveau van het onderwijs werd bij de invoering van deze landelijke richtlijnen overgelaten aan de hogescholen zelf, iedere theaterfaculteit kon als het ware haar eigen kleur bepalen. Ze werden geacht hun eindtermen, hun curriculum en hun toetsing op een onderscheidende manier te gaan afstemmen op deze competenties. Letterlijk staat in het rapport te lezen:

'Zij [de landelijke Visitatiecommissie Theater. $\mathrm{HH}$ ] realiseert zich dat het geven van niveau-indicaties een moeilijke opgaaf is. In de notitie 'Naar een Kwalificatiestelsel Kunstonderwijs' staat vermeld dat de opleidingskwalificaties gericht op artistieke prestaties weliswaar observeerbaar zijn, maar de aantoonbaarheid ervan is lastig, omdat artistieke kwaliteit niet makkelijk meetbaar is. Bovendien is de vraag hoe 'goed' of 'hoog' die prestatie moet zijn en wanneer 'goed', goed genoeg is in de zin van basiskwaliteit. Het bepalen van deze

\footnotetext{
${ }^{168}$ Uitstroomprofielen van het Opleidingsprofiel Theater werden gedefinieerd als Acteur en Theatermaker. Onder het uitstroomprofiel Acteur vielen de opleidingsvarianten acteur, kleinkunstenaar, mimespeler en performer; onder het uitstroomprofiel Theatermaker vielen de opleidingsvarianten theatermaker, regisseur, dramaschrijver, theatertechnicus, producent podiumkunsten, productiedramaturg en theatervormgever. Landelijk werden hierbij de volgende tien onderliggende competenties vastgesteld, verschillend uitgewerkt voor beide uitstroomprofielen: creërend vermogen, visie, communicatief vermogen, vermogen tot samenwerking, ambachtelijk vermogen, ondernemerschap, omgevingsgerichtheid, lerend vermogen, reflectief vermogen en innovatief vermogen.
} 
basiskwaliteit wordt, aldus de notitie, dan ook overgelaten aan de verschillende onderwijsinstellingen zelf' (HBO-raad, 2003, p. 26).

Doel van de vastgestelde uitstroomprofielen was transparantie: minder versnippering en betere afstemming van de opleidingsvarianten op elkaar en op de veranderende beroepspraktijk.

In 2010 werd de gehele kunstensector onaangenaam verrast door het culmineren van de Nederlandse politieke ontwikkelingen in de richting van de verkiezingen. Die leverden een eclatante overwinning op voor de combinatie van neoliberale en populistische wereldbeelden. Zonder hier dieper in te gaan op de bredere gevolgen van deze omslag in de politieke verhoudingen kan gezegd worden dat dit momentum een waterscheiding vormde voor de status van kunst en cultuur. ${ }^{169}$ Dit discours rond de kunsten raakte het theater en het theateronderwijs. De HBO-raad stelde in dit klimaat al eerder een externe commissie in om aanbevelingen te doen over onder meer de positionering van het kunstonderwijs vanuit een analyse van ontwikkelingen in kunst, cultuur en creatieve industrie en hun betekenis voor het kunstonderwijs. In het rapport Onderscheiden, verbinden, vernieuwen. De toekomst van het kunstonderwijs, een advies van de Commissie-Dijkgraaf voor een sectorplan kunstonderwijs uit 2010, wordt afstand genomen van de traditionele benadering in het kunstvakonderwijs, gebaseerd op autonome kunstbeoefening in per discipline geordende kunstdomeinen. Mostert \& Van Bakelen verzetten al de piketpaaltjes voor de beroepsprofielen van acteur en regisseur naar theatermaker. Dat werd toentertijd ingegeven door veranderende theateresthetische ontwikkelingen; hun beroepsprofielen voor de theatermaker vertoonden in 1999 nog een traditioneel theaterreferentiekader (Mostert \& Van Bakelen, 1999, p. 7). Door de CommissieDijkgraaf werd ingezet op het groeiende belang van toegepaste kunst en innovatie van het kunstenaarschap, op de bindende kracht van de creatieve industrie, op het belang van cultureel ondernemerschap en op een veranderende maatschappelijke rol van de kunsten (Commissie Dijkgraaf, 2010). Volgens het rapport betekende deze ontwikkelingen dat het hoger kunstonderwijs heringericht diende te worden vanuit de gedachte dat het werkveld voor kunstprofessionals zich aan het ontvouwen was over het sectoroverschrijdende landschap van de creatieve industrie en dat er structureel meer aandacht moest komen voor cultureel ondernemerschap bij het opleiden van kunstenaars.

Het rapport was een advies aan de HBO-raad en de minister van OCW en geen beleidsregel maar het werd welwillend ontvangen door betrokken beleidsgremia en de kunstonderwijssector. Het discours over het kunstenaarschap en zijn maatschappelijke

\footnotetext{
${ }^{169}$ In Hoofdstuk 6 ga ik dieper in op deze omwenteling in het denken over kunst en cultuurbeleid.
} 
rol verscherpte het debat tussen pleitbezorgers voor cultureel ondernemerschap vanuit een neoliberaal standpunt en die voor cultureel ondernemerschap als domein van mogelijke kritische, geëngageerde en zelfs subversieve artistieke strategieën.

\section{De onderscheidende kleur van Maastricht}

De veranderende beroepspraktijk voor theaterkunstenaars, die het uitgangspunt vormde voor richtlijnen en aanbevelingen met betrekking tot het kunstvakonderwijs, dicteerde vanaf de jaren negentig ingrijpende mutaties in het theateronderwijs. In de loop van de jaren negentig vonden de visie van theatertheoretici als Marianne van Kerkhoven, later het postdramatische theater zoals beschreven door Hans-Thies Lehmann, de bevindingen van de Projectorganisatie Kunstvakonderwijs en de toenemende digitale storm in de samenleving hun weg naar de opleidingen, ook naar de Toneelacademie Maastricht. Zo was bijvoorbeeld het hierboven aangehaalde artikel van Van Kerkhoven, Niet spelen, maar gespeeld worden (Kerkhoven, 2002) een van de stukken voor een studiedag op 22 november 2000 in het kader van de herstructurering van het onderwijs op de Toneelacademie. In de uitnodigingsbrief van directie en coördinatoren aan alle betrokkenen bij de Toneelacademie en in een bijdrage van Pieter Mostert, spreekt de toon van het tijdvak:

'Op grond van de resultaten van ons aller voorwerk van het afgelopen jaar hebben we besloten dat we in september 2000 beginnen met de nieuwe afstudeervariant Theatraal Performer. (...) Tegelijkertijd zullen we het komend jaar uitgebreid studie maken van het rendement en de haalbaarheid van een ander onderwijsmodel voor onze academie met ingang van studiejaar 2001-2002. (...) Naar aanleiding van onze discussie over de Performancevariant is er gevraagd om fundamenteler na te denken over de totale inrichting van het onderwijs aan de Toneelacademie' (Toneelacademie Maastricht, 2000).

'Deze notitie gaat over de vernieuwing van het theateronderwijs. Ik beschrijf de consequenties die uit dit gedachtegoed, zoals verwoord in het beroepsprofiel theatermaker, volgen voor het theateronderwijs.(...) Binnen het profiel van theatermaker zijn niet zozeer 'beroepen' onderscheiden, maar 'rollen'; van beroepen vervul je er maar een, van rollen kun je er meer dan een vervullen. Dat laatste is in de theaterpraktijk het geval. (...) de ontwikkelingen doen zich vooral op de grensvlakken voor, studenten zullen daarom moeten worden aangemoedigd om deze grensvlakken te verkennen; de opleidingsstructuur dient dat te faciliteren' (Toneelacademie Maastricht, 2000). 
Centraal in de inhoudelijke en onderwijskundige herstructurering van de Toneelacademie waren de volgende zaken: een herijking van het curriculum, aangestuurd door de hybridiserende beroepspraktijk op basis van een veranderende theater-, performance- en media-esthetiek en een omslag van aanbodgestuurd onderwijs naar zelfverwerkinggestuurd onderwijs. In deze zaken kunnen we herkennen wat Van Kerkhoven zei: 'Acteurs en regisseurs hoeven niet meer uitsluitend opgeleid te worden om de woorden van auteurs te vertolken' (Kerkhoven, 2002, p. 81-94). In veel gevallen zijn theaterkunstenaars inmiddels auteur, acteur en regisseur tegelijk en gebruiken ze bij hun performatieve scheppingsproces alles wat voorhanden is; de persoonlijkheid en het talent van de theatermaker zijn daarbij belangrijker geworden dan de potentie om de verzameling iconische personages uit de westerse literair dramatische traditie te kunnen vertolken. Taal kan daarbij nog steeds richtinggevend zijn in individuele leertrajecten maar hoeft dat niet langer generiek te zijn, er dienen zich inmiddels in de recente Nederlandse theater-, performance- en mediapraktijk geaccepteerde andere 'taal'-systemen aan.

De herstructurering, die in de afgelopen vijftien jaar haar beslag heeft gekregen, omvatte niet alleen curriculumherzieningen en een verandering van onderwijsvisie. Bij het verwerken van nieuwe noties over de theaterpraxis hoorde ook een heroriëntatie op de actuele theater-, performance- en mediapraktijk in brede zin op basis van muterende beroepsprofielen. Bovendien diende de structuur van de opleiding te passen in het Bachelor-Mastersysteem, waarmee onderzoek formeel onderdeel werd van de werking van de practice based theaterfaculteit. De heroriëntatie op de actuele praktijk vertaalde zich in het uitbouwen van contacten (stages, gastdocenten) in de film- en mediawereld, in het streven naar structurele relaties met de wetenschap (aanscherpen van bodies of knowledge) en in het stimuleren van connecties met andere kunstdisciplines en met andere maatschappelijke sectoren dan alleen de kunsten. De implementatie van gericht onderzoek in het kunstvakonderwijs is vooralsnog niet eenvoudig gebleken; er blijkt een weerbarstige discursieve discrepantie te bestaan tussen academic en practice based researchers op basis van verschillend gehanteerde terminologie en werkwijzen (Borgdorff, 2009; Nelson, 2013). Voor academici heeft onderzoek een methodologisch meer gekaderde lading dan voor kunstenaars en opleiders van kunstenaars, die meer opereren als reflective practitioners.

De inzichten rond een veranderende beroepspraktijk van theaterkunstenaars leidden bij de herstructurering in $\mathbf{2 0 0 0}$ ook tot het ontwerpen en implementeren van de opleiding tot Theatraal Performer, later opleiding tot Performer. Dit opleidingstraject startte met een curriculum dat recht wilde doen aan de veranderende podiumkunstenpraktijk: uitdrukkelijke aandacht in theorie zowel als in de praktijkprojecten voor de maatschappelijke en culturele impact van media en 
intermedialiteit. Vanaf de start werd gebouwd aan een divers netwerk van gastdocenten naast dat van gevestigde theater- en filmregisseurs en werd naarstig gezocht naar adequate selectiecriteria voor een 'nieuw soort' theaterstudenten met andere ambities dan de gemiddelde theateracteur of regisseur. Dit implementatieproces is een lastig traject geweest van trial \& error en kreeg na de pioniersfase pas vaste vorm na het verhuizen vanuit de periferie van het instituut naar het hart van de acteursopleiding. Vanaf de zomer van 2002 ging de opleidingsvariant verder als gecombineerde acteurs/performersopleiding met gespecialiseerde profielen voor acteurs en performers.

In datzelfde jaar werd de Toneelacademie Maastricht gevisiteerd door de Visitatiecommissie Theater. De HBO-raad gaf in het kader van een landelijk kwaliteitszorgtraject de commissie de opdracht mee om 'op landelijk en op hogeschoolniveau een beredeneerde beoordeling te geven van de onderwijskwaliteit' en 'het doen van beargumenteerde aanbevelingen voor kwaliteitsverbetering' (HBOraad, 2003, p. 222); de commissie bezocht zeven theaterscholen in Nederland. De Visitatiecommissie Theater stond 'ten principale' positief tegenover de nieuwe studierichting, die volgens de commissie getuigde van de wens van de academie actief bij te dragen aan innovatie (HBO-raad, 2003, p. 173). Tegelijkertijd had de commissie forse kritiek op het prille curriculum van de performersopleiding. Men had oog voor de aanloopproblemen maar vond het programma van het tweede jaar te vrijblijvend en de body of knowledge te smal; er werd geconstateerd dat er meer inhoudelijke expertise noodzakelijk was. (HBO-raad, 2003, p. 176). Zes jaar later werd de Toneelacademie weer gevisiteerd, ditmaal door de in het licht van de BaMa-structuur in het leven geroepen Nederlands Vlaamse Accreditatie Organisatie (NVAO). De performersopleiding werd na deze visitatie niet expliciet genoemd, maar uit het visitatierapport kan impliciet worden opgemaakt dat deze verbreding van het opleidingspakket en de verwevenheid van performancekenmerken met de andere opleidingsvarianten deze keer positief beoordeeld werden. ${ }^{170}$

Ten behoeve van die accreditatieprocedure in 2008 stelde de Toneelacademie een zelfevaluatie op, getiteld De Kleur van Maastricht. Opleidingsvisie Toneelacademie Maastricht (Toneelacademie Maastricht, 2008). Daarin verwoordde de opleiding het vertalingsproces van de veranderende beroepspraktijk (beroepsprofielen) naar een

\footnotetext{
${ }^{170}$ De Toneelacademie krijgt van de commissie het onderscheidende 'bijzondere kenmerk: intermedialiteit' (NVAO, 2008, p. 56) voor de manier waarop intermediale kenmerken verweven zijn met de diverse opleidingscurricula; dit is geen exclusieve verdienste van de performersopleiding, maar we kunnen wel stellen dat deze opleiding meer dan de andere opleidingsvarianten gekleurd is door een intermediale blik op de wereld. Door de 'besmetting' en door het bijzondere kenmerk komt de performersopleiding in een beduidend beter daglicht te staan dan in 2002. In het rapport wordt letterlijk gesproken van een positieve 'besmetting' in de zin van het wederzijds raken van elkaar van de opleidingsvarianten acteur, theatraal performer en regisseur (NVAO, 2008, p. 20).
} 
aanpassing van de richting en de structuur van de opleiding. Uitgangspunt voor de opleidingsvisie in 2008 waren de opleidingsprofielen zoals die door het Netwerk Theater en de HBO-raad in 2002 zijn vastgesteld (Netwerk Theater - Werkgroep Opleidingsprofiel Theater, 2002). Het profiel van de Toneelacademie onderscheidde zich naar eigen zeggen op de volgende inhoudelijke keuzes: de aangeboden opleidingen worden gekenmerkt door vaktechnisch vermogen (stem- en spraakonderwijs, bewegingsonderwijs ${ }^{171}$ en ontwikkeling van muzikaal vermogen), door eminente tekstbehandeling (hoge taalcultuur, integratie van analytische, spraaktechnische en speltrainingen), door een professionele beroepsattitude gekenmerkt door passie en discipline (open mentaliteit, samenwerking, cultureel ondernemerschap, weerbaarheid en eigen initiatief) en door het vermogen om intermediaal en interdisciplinair te werken.

$\mathrm{Na}$ de deconstructieve noties van Van Kerkhoven, Lehmann en Fischer-Lichte is de keuze voor een specifieke 'hoge taalcultuur' opmerkelijk te noemen, maar zij is niet onbegrijpelijk. De Maastrichtse methode staat erom bekend dat het niet gaat om 'mooi spreken' volgens een bepaalde standaard, maar om een zo groot mogelijk instrumenteel bereik van de stem inclusief een soms noodzakelijke 'lelijkheid' (Zwietink, 2000). Lehmanns notie over Sprache als Ausstellungsobjekt, over de autonomisering en muzikalisering van spraak, heeft zijn weg gevonden naar de trainingslokalen van theateropleidingen (Lehmann, 1999, p. 266). Ook is een connectie te maken met wat Swyzen en Vanhoutte stellen in Het Statuut van de tekst in het postdramatische theater, dat tekst in het theater veel breder opgevat kan worden dan alleen om betekenis te genereren in een literair dramatische structuur, waarmee zij enige tegenkleur geven aan een van de belangrijkste conclusies van Lehmann in 1999 over de afnemende betekenis van taal in het theater (Swyzen \& Vanhoutte, 2011).

De Toneelacademie kreeg in 2008 in de eindrapportage een positieve accreditatiebeoordeling. Op alle deelfacetten waarop men oordeelde, scoorde de opleiding 'positief', 'goed', 'voldaan' en zelfs een paar maal 'excellent' (NVAO, 2008, pp. 11-12). Er werden slechts enige kritische opmerkingen teruggegeven op het gebied van administratieve zaken als de vastlegging van beoordelingen uit het werkveld, verbetering van de jaaroverzichten en consistentie van documentatie en archivering van leerprocessen. In 2014 werd de Toneelacademie opnieuw gevisiteerd in het kader van de periodieke accreditatie. Hoewel het accreditatierapport pas in het voorjaar van 2015 wordt verwacht, is duidelijk dat de commissie nu kritischer was. Een van de saillante verbeterpunten die werden geformuleerd, was bijvoorbeeld de constatering dat op de Toneelacademie Maastricht het percentage docenten met een niet-westerse

\footnotetext{
${ }^{171}$ Er bestaat een geboekstaafde methode voor stem- en spraakonderwijs die in de loop van 35 jaar is ontwikkeld (Zwietink, 2000), en op het gebied van bewegingstraining krijgen studenten te maken met de uit Amerika afkomstige Viewpointtraining.
} 
achtergrond nog niet in de verste verte een afspiegeling is van de hedendaagse Nederlandse samenleving. ${ }^{172}$

In het visiedocument ten behoeve van deze laatste accreditatie, Over Grenzen (Kort \& Olaerts, 2014), wordt inhoudelijk veelvuldig gerefereerd aan het rapport Onderscheiden, verbinden, vernieuwen. De toekomst van het kunstonderwijs (Commissie Dijkgraaf, 2010).

'Behoud het goede en omarm de noodzakelijke en de gewenste vernieuwingen is het adagium voor de Toneelacademie die enerzijds schatbewaarder is van een rijke traditie en anderzijds jonge generaties opleidt voor hun toekomst. Die toekomst wordt meer en meer gekenmerkt door de combinatie van artistiek vakmanschap en zelforganisatie in een kunstenpraktijk die in wisselende ketens van samenwerkende professionals opereert en die minder en minder onderscheid maakt in de kwaliteiten die voor de autonome kunstpraktijk en die voor de toegepaste praktijk vereist zijn. De kunstenaar van de 21 e eeuw is als zzp'er een artistiek ondernemer die zijn talent en kwaliteit in stelling kan brengen in verschillende omgevingen. Hij schakelt tussen de toneelkunst, film/tv/nieuwe media, nationale en internationale context, multi- en interdisciplinaire projecten en maatschappelijke toepassingen in bijvoorbeeld de zorg, onderwijs en educatie en andere economische toepassingsgebieden. In al deze omgevingen is de bron van het artistieke theatrale vakmanschap de kern van waaruit de Toneelacademie haar studenten leert dansen op de 1000 podia die zich in potentie aandienen in de 21 e eeuw' (Kort \& Olaerts, 2014). ${ }^{173}$

Deze notie van verbreding van het werkveld van de kunstenaar is terug te vinden in meerdere recente beleid- en visiedocumenten van de Toneelacademie Maastricht en de Arts Faculty Maastricht waarvan de academie onderdeel uitmaakt. De algemene teneur van de laatste jaren is die van een discursieve verhouding tussen autonome en toegepaste kunst, tussen onderzoekskunst en publiekskunst. ${ }^{174}$ Hier openbaart zich nog steeds dezelfde discrepantie als die waar Van Kerkhoven in 1991 over schrijft, tussen een kleine onderzoeksklasse van grensverleggende kunstenaars en de

\footnotetext{
${ }^{172}$ Er is anno 2015 slechts één vaste docent met een niet-westerse achtergrond verbonden aan de Toneelacademie Maastricht.

${ }^{173}$ Directeur van de Arts Faculty Maastricht, Leo Swinkels, in het voorwoord van Over Grenzen (Kort \& Olaerts, mei 2014).

${ }^{174}$ In april 2012 verscheen Kunstonderwijs in de 21e eeuw bij Arts Faculty Maastricht van Zuyd Hogeschool (Arts Faculty Maastricht/Zuyd Hogeschool, 2012) als een strategisch beleidsdocument voor de periode 20122013; in mei 2014 Theater van de 21e eeuw: traditie en vernieuwing (Toneelacademie Maastricht, 2014), met strategische doelen tot 2016, en Over Grenzen. Kritische reflectie Toneelacademie Maastricht, ten behoeve van de accreditatieprocedure van 2014 (Kort \& Olaerts, 2014).
} 
samenleving als één groot publiek, alleen nu als deel van een veel breder kunstdiscours over de maatschappelijke rol van kunst en cultuur. Daar waar theoretici zich voornamelijk richten op veranderende theater- en performance-esthetiek in een theatervakdiscours, lezen we in de beleidsteksten en discussiestukken uit de theateropleidingssector zelf vooral een bekommernis om de meer praktische uitkomsten van de veranderende kunstenpraktijk, zoals de differentiatie van kunstopleidingen en kunstenaarspraktijken, inclusief bijbehorende debatten over arbeidsomstandigheden voor toekomstige kunstenaars en een zelfkritische reflectie op de rol van kunst in de samenleving.

\subsection{Conclusies}

Op theateropleidingen in Nederland werd het afgelopen decennium zorgelijk gekeken naar een krimpende arbeidsmarkt in de gesubsidieerde theatersector. Tegelijkertijd veranderde het performatieve aanbod, zich in een veelvoud verspreidend over een breder landschap. Deze ontwikkelingen hebben consequenties voor de opleidingen. De gevolgen voor de Toneelacademie zijn exemplarisch voor transitieprocessen op veel theateropleidingen en ze weerspiegelen interculturele, intermediale en internationale processen zoals die onder meer door Lehmann (1999) en Fischer-Lichte (2004) werden vertaald in een nieuwe theater- respectievelijk performance-esthetiek. Door de veranderende praktijk wordt niet alleen het opleiden van theaterprofessionals beïnvloed, het zorgt ook voor een andere positionering van de opleidingen. Waren ze in de hoogtijdagen van de literair dramatische traditie vooral faciliterend voor de gevestigde theaterpraktijk, we kunnen nu stellen dat door het vervagen van de grenzen tussen traditionele beroepsprofielen als acteur, regisseur, mediakunstenaar en performer, en de groeiende rol van onderzoek en zelfreflectie ten aanzien van deze muterende beroeps- en opleidingsprofielen, de theateropleidingen medeconstituerend aan het worden zijn voor de actuele performatieve praktijk.

Het postdramatische theater, het performancebegrip en mediakritisch professionalisme zijn manifest geworden issues voor alle opleidingsprofielen op de Toneelacademie. De actuele beroepspraktijk dwingt zo een transformatie af van de eenduidige toneelopleiding die de Toneelacademie eens was, naar een theater-, performance- en mediaopleiding met een professioneel gedifferentieerde uitstroom. De relatie van de opleiding met de beroepspraktijk toont een verschuiving van een zuivere gerichtheid op het Nederlands gesubsidieerde theater naar de internationale hybride kunstenwereld van theater, film, televisie, performancepraktijken en nieuwe media, en naar de productiepraktijken van festivals in Nederland en in het buitenland. Bovendien is er op de opleidingen ruimte vrijgemaakt voor onderzoek, waarbij practice based research en practice as research centraal staan. De implementatie van 
onderzoek in diverse gedaantes is nog niet op alle niveaus organisch vanzelfsprekend en zal de komende jaren nog veel aandacht vragen.

De Toneelacademie heeft de intentie om zich internationaal te profileren; ze toont dit door groeiende samenwerking en uitwisseling te zoeken met theater- en performancefaculteiten in het buitenland, door studenten te stimuleren zich op een internationale podiumkunsten- en mediapraktijk te richten en door op onderzoeksgebied buitenlandse partners te zoeken. ${ }^{175}$

De opleidingspraktijk van de Toneelacademie toont ook de invloed van interculturele ontwikkelingen. Er voltrekt zich een transitie van een hagelwitte Nederlandse populatie van theaterstudenten naar een diverse, gekleurde en internationale gemeenschap. Hierbij moet wel worden opgemerkt dat de uitstroom weliswaar inmiddels een substantieel aantal gekleurde acteurs kent maar dat de performers, regisseurs en vormgevers in dat opzicht achterblijven, mogelijk vanwege gebrek aan rolmodellen in Nederland en Vlaanderen. De Toneelacademie geeft daarbij zelf geen goed voorbeeld; er werken nauwelijks docenten met een niet-westerse achtergrond. Interculturaliteit werd tot voor kort vaak alleen in verband gedacht met interferenties tussen westerse en niet-westerse culturen. Interculturele ontwikkelingen zijn echter ook op te vatten als interacties tussen 'hoge' en 'lage' cultuur of tussen canoniek toneelrepertoire en film, televisie en digitale media. Het interculturele discours op deze meerduidige manier opgevat, manifesteert zich op de Toneelacademie en heeft invloed op de doorontwikkeling van de opleidingsprogramma's. Voorheen eenduidig theatraal vakmanschap is zich aan het verbreden tot een breed samengesteld palet van performatief vakmanschap. Afsplitsingen van het westerse theater tekenen zich af als organische vertakkingen van performatieve uitdrukkingsmogelijkheden en niet als definitieve breuken met een theatertraditie. Theateropleidingen zijn op een nomadische manier dit veranderend vakgebied in kaart aan het brengen en zich in een veranderend theater-, performanceen medialandschap aan het herpositioneren.

Theatervakmanschap wordt op theateropleidingen steeds vaker breed geformuleerd en gekoppeld aan het vervullen van mogelijke rollen in wisselende combinaties in plaats van aan het uitoefenen van een gekaderd eenduidig beroep; aan doorlopende reflectie op de eigen praktijk; aan practice based artistiek onderzoek en aan cultureel ondernemerschap (Netwerk Theater, 2009; Commissie Dijkgraaf, 2010; Arts Faculty Maastricht/Zuyd Hogeschool, 2012; Toneelacademie Maastricht, 2014). Deze transitie van een trainingsisolatie ter voorbereiding op een traditioneel

\footnotetext{
${ }^{175}$ In juni 2014 werd een internationale samenwerkingsintentie geïnitieerd door zeven Europese theaterscholen in Oslo, Helsinki, Warschau, Berlijn, Luik, Brussel en Maastricht. Deze theateropleidingsinstituten ondertekenden een intentieverklaring om de komende jaren als een Europese Theaterschool te gaan samenwerken en coproduceren.
} 
acteursmetier in Nederland naar een interculturele differentiatie van repertoire, speelstijlen, bronnen en werkwijzen betekent voor het gevestigde kunstvakonderwijs een paradigmaverschuiving die nog gaande is. Deze verschuiving toont zich minder in majeure revolutionaire koerswijzigingen, maar meer in geleidelijke evolutionaire bewegingen, in aanpassingen in curriculumonderdelen, in het initiëren van nieuwe opleidingstrajecten en in het aantrekken van andere specialisten en gastdocenten dan voorheen. 


\section{Hoofdstuk 6 Theaterbeleid in transitie}

'De wereld is in beweging. Globalisering, individualisering, veranderende internationale verhoudingen, informatisering, verstedelijking, vergrijzing, migratie en economische crisis: er wordt een deuk geslagen in ons vooruitgangsdenken, de mensen ervaren onzekerheid en er is wantrouwen tegen grote instituties. De grote maatschappelijke trends van deze tijd trekken ook hun sporen in de culturele wereld. Kunstenaars en cultuurinstellingen hebben ermee te maken, anticiperen en reflecteren erop. Als er in de wereld veel gebeurt, gebeurt er veel in de kunsten. Dat is niet altijd manifest. Maar zichtbaar zijn wel de opkomst van nieuwe kunstvormen, andere patronen in cultuurbezoek en vrijetijdsbesteding, nieuwe organisatievormen en onderstromen' (Raad voor Cultuur, 2014, p. 13).

\section{1}

Inleiding

In de voorgaande drie casestudiehoofdstukken hebben we gezien hoe zich bij gezelschappen, podia en theateropleidingen transformaties voordoen. In deze vierde casestudie vraag ik me af hoe het Nederlandse theaterbeleid zich verhoudt tot deze transformaties. Gezelschappen, podia en opleidingen bevinden zich niet in een vacuüm, de sector wordt voor een deel geordend en georganiseerd door het Nederlandse kunst- en cultuurbeleid. Na de Tweede Wereldoorlog is de overheid een richtinggevende partij geworden, een actor in de wereld van de kunsten, ook in die van het theater. Ondanks toenemende overheidsinvloed hebben Nederlandse kabinetten vanaf het begin van de jaren negentig getracht steeds meer concrete uitvoeringstaken van het landelijke kunst- en cultuurbeleid over te hevelen naar cultuurfondsen. Zo is een merkwaardige paradox ontstaan: aan de ene kant heeft de overheid zich verder willen terugtrekken uit de cultuursector, maar aan de andere kant is ze in werkelijkheid belangrijker geworden als regisseur.

Beleidsuitgangspunten van de overheid manifesteren zich in het waarom van theaterbeleid (verheffen, participatie), het hoe (subsidiesystematiek) en het wie (welke gezelschappen en podia). Veranderingen van uitgangspunten worden zichtbaar in verschuivingen in het discours van het theaterbeleid. Dit discours behelst niet alleen 
de manier waarop over theaterbeleid wordt gesproken, het heeft ook een constituerende werking voor het Nederlandse theatersysteem.

In dit hoofdstuk onderzoek ik het verschuivend taalgebruik van het theaterbeleid door een beknopte discoursanalyse uit te voeren. Beknopt, omdat een volledig uitgewerkte discoursanalyse meer ruimte vraagt dan mij hier ter beschikking staat. In het verleden zijn er al eerder studies uitgevoerd naar het Nederlandse theaterbeleid die kenmerken vertoonden van een discoursanalyse. ${ }^{176}$ De term discours duidt daarbij op een betekenisconstituerend vertoog waarbij verschillende actoren betrokken zijn, en wordt beschouwd als een geheel van min of meer samenhangende ensembles van ideeën, concepten en categoriseringen. Een discours is op te vatten als een krachtenspel dat verder gaat dan taal. De manier waarop gehandeld wordt in een bepaald vakgebied wordt gevormd, bestendigd en veranderd in en door taal. Taal weerspiegelt en bepaalt daarbij de machtsverhoudingen (Foucault, 2010; Hajer, 1995, 2000; Mills, 1997; Hall, 1997 \& Tonkiss, 1998).

Zo kunnen de taal van beleidsstukken, de kennis die daarmee geproduceerd wordt en de specifieke invloed daarvan in de culturele wereld met elkaar gecombineerd worden tot wat politicoloog Maarten Hajer een discursieve orde noemt (Hajer, 1995, 2000). Het Nederlandse theatersysteem is op te vatten als zo'n discursieve orde, een arena waarbinnen diverse actoren met elkaar de strijd aangaan om het systeem van instituties vorm te geven in een bepaalde richting. De instituties waaruit het systeem is opgebouwd, krijgen hun betekenis via een bepaald idee van wat theater is, wat het behoort te doen. Het idee van wat theater is, wordt andersom ook weer beïnvloed door wat er in de instituties gebeurt. In een beleidsdiscours wordt gediscussieerd met gebruikmaking van een specifiek vocabulaire (Hajer, 2000, p. 19). In het theaterbeleidsdiscours worden concepten als volksverheffing, horizontale- en verticale spreiding, cultuurparticipatie, maatschappelijke relevantie, theatercollectieven, culturele diversiteit, topkunst en cultureel ondernemerschap bewust ingezet om inhoud te geven aan beleidsprogramma's. De begrippen worden in de loop der tijd voor actoren die ze hanteren vanzelfsprekend. Ze geven de werkelijkheid van het moment vorm, maar kunnen in een andere periode door andere actoren anders opgevat of geproblematiseerd worden. Wanneer uiteenlopende actoren zich van dezelfde termen bedienen, vormen zich vertoogcoalities of verhaallijnen. De sleutelfunctie van verhaallijnen is dat ze samenhang bieden in de verzameling van verschillende discursieve onderdelen van een wijdlopig problematisch

\footnotetext{
${ }^{176} \mathrm{Ik}$ verwijs hier naar de masterscripties theaterwetenschap van Anneke van der Linden (Linden, 2007) en van Marieke Nooren (Nooren, 2006). Zij benoemen allebei het gebruik van het discoursanalytische instrumentarium bij hun onderzoek. Ook de dissertatie van Warna Oosterbaan Martinius, Schoonheid, Welzijn, Kwaliteit (Oosterbaan Martinius, 1990) heeft elementen in zich van een discoursanalyse zonder dat de schrijver dat expliciet benoemt.
} 
domein als een beleidsdiscours (Hajer, 1995, p. 56). Met veranderend beleid veranderen de richtinggevende verhaallijnen. Nieuwe verhalen kunnen dan botsen met het oude verhaal. Met een discoursanalyse kan de constitutie van zowel het gevestigde als het afwijkende onderzocht worden en kunnen controverses worden blootgelegd (Hajer, 1995, p. 54).

Het gaat er in dit hoofdstuk om te achterhalen hoe in het theaterbeleidsdiscours sommige elementen als kloppend worden ervaren en andere als problematisch. De vraag die hierbij centraal staat is: welke veranderingen hebben zich voorgedaan in de verhaallijnen van het theaterbeleidsdiscours? Hoe verhouden deze transformaties in het theaterbeleidsdiscours zich tot een veranderende theater- en performanceesthetiek en tot de transformaties die zijn waar te nemen bij gezelschappen, podia en opleidingen?

De belangrijkste bronnen voor dit onderzoek naar het theaterbeleidsdiscours zijn Nederlandse beleidsdocumenten en rapporten op het gebied van theater van de Raad voor Cultuur, van het Ministerie van Onderwijs, Cultuur \& Wetenschappen (OCW), van koepelorganisaties en sectorinstituten als de Boekmanstichting, het Theater Instituut Nederland (TIN), de Vereniging van Nederlandse Theatergezelschappen (VNT), de Vereniging van Schouwburg- en Concertgebouwdirecties (VSCD) en de Nederlandse Associatie voor Podiumkunsten (NAPK). De studies van het Nederlandse theaterbestel en het Nederlandse cultuurbeleid door Van Maanen (1997), Van Dulken (2002), Oosterbaan Martinius (1990) en Pots (2002) hebben me geholpen een historisch overzicht te krijgen. Ik heb de publicaties over de totstandkoming van de nota Kunst van Leven (Ministerie van OCW, 2007) bestudeerd, de tussentijdse evaluatie ervan door Van der Horst en Zoutman (Horst \& Zoutman, 2010), de voorstellen tot bezuinigingen op de kunst- en cultuursector van het gedoogkabinet-Rutte I in de vorm van de beleidsbrief Meer dan kwaliteit, een nieuwe visie op cultuurbeleid (Ministerie van OCW, 2011) van staatssecretaris Halbe Zijlstra, en reacties op deze herinrichting van het subsidiestelsel vanaf 1 januari 2013. Tot slot betrek ik in mijn onderzoek de publicatie door de Raad van Cultuur van juni 2014, De Cultuurverkenning.

Ontwikkelingen en trends in het culturele leven in Nederland (Raad voor Cultuur, 2014). Dit laatste document is geen advies van de Raad maar is bedoeld als aftrap voor een publiek cultuurdebat in de aanloop naar de advisering over het cultuurbeleid voor de periode 2017 - 2020. Het uitbrengen van dit advies staat gepland voor de lente van 2015.

Deze studie naar ontwikkelingen in het Nederlandse theaterbeleidsdiscours is gebaseerd op bovengenoemd bronnenonderzoek in combinatie met literatuurstudie en participerende waarneming. Ik zal in $\S 6.2$ de belangrijkste transities in het discours belichten door ze nader te beschouwen op specifiek taalgebruik in een opvolgende 
reeks richtinggevende Nederlandse beleidsdocumenten. ${ }^{177}$ In $\S 6.3$ analyseer ik met behulp van Hajers discoursanalyse de verhaallijnen die te destilleren zijn uit het gebezigde theaterbeleidsvocabulaire. In $\S 6.4$ trek ik conclusies ten aanzien van de veranderingen in het Nederlandse theaterbeleidsdiscours van de afgelopen decennia en de verhouding daarvan tot de transformaties van gezelschap, podium en opleiding.

\subsection{Het Nederlandse theaterbeleidsdiscours}

\section{Schoonheid, welzijn, kwaliteit en cultureel ondernemerschap}

De constitutie van het huidige cultuurbeleid, waaronder het rijksbeleid ten aanzien van theater, gaat terug tot net na de Tweede Wereldoorlog. ${ }^{178}$ Warna Oosterbaan Martinius onderscheidt in zijn proefschrift over legitimering en toewijzingsproblemen in het Nederlandse kunstbeleid van na de Tweede Wereldoorlog tot 1990 drie periodes. Hij typeerde die periodes in zijn titel door drie begrippen: Schoonheid, Welzijn, Kwaliteit (Oosterbaan Martinius, 1990); elk van deze begrippen kenmerkt een periode in het Nederlandse kunstbeleid. Het kunstbeleid stond van 1945 tot ongeveer 1965 in het teken van het stimuleren en verspreiden onder de bevolking van schone kunsten. Kunst werd per definitie gezien als schoonheid in de zin van het verhevene; dit werd op een dominante manier via confessionele en sociaaldemocratische zuilen uitgedragen. Vervolgens werd van 1965 tot in de tweede helft van de jaren zeventig het kunst- en cultuurbeleid gekenmerkt door de term welzijn, sterk gekleurd door de maatschappelijke reuring van emancipatoire democratiseringsbewegingen vanaf het midden van de jaren zestig. Kunst moest en zou maatschappelijk relevant zijn. Daarnaast waren de belangrijkste steekwoorden voor het cultuurbeleid van die periode toegankelijkheid en participatie. Toen begin jaren tachtig een artistieke luwte in de Nederlandse theaterwereld werd geconstateerd, na zoveel jaren maatschappelijke relevantie en politiek engagement, gooide de overheid het roer om en richtte zich met de nieuwe neoliberale wind in de rug op het ondersteunen van artistieke kwaliteit in de kunst (Maanen, 1997, p. 147). Voor elk van de periodes die door Oosterbaan Martinius met de termen schoonheid (1945-1965), welzijn (19651982) en kwaliteit (1982-1990) gekenmerkt werden, evenals voor de daaropvolgende

\footnotetext{
${ }^{177}$ Voor een overzicht van elkaar opvolgende cultuurbeleidsdocumenten vanaf de jaren zestig en hun betekenis voor de theatersector, zie: Sanering van de subsidiëring. Overheidsbemoeienis met monumentenzorg, film en toneel vanaf de jaren zestig (Dulken, 2002).

${ }^{178}$ Inspiratiebron voor het na de oorlog vormgeven van een coherent landelijk cultuurbeleid was het als één systeem te herkennen homogene landelijke cultuurbeleid van de bezetter (Kulturkammer en Departement voor Volksvoorlichting en Kunsten, 1940-1945). Daarnaast leidde de actieve rol die kunstenaars hadden gespeeld in het verzet ertoe dat de kunsten tot op zekere hoogte konden rekenen op draagvlak en steun onder de bevolking.
} 
periode vanaf het begin van de jaren negentig tot nu (1990 - 2015), een periode in toenemende mate gekenmerkt door termen als cultureel ondernemerschap en culturele diversiteit, zijn richtinggevende documenten aan te wijzen. In elk van die documenten vinden we een voor de tijd exemplarische terminologie die het discours voedt. Hierna zal ik een aantal kernbegrippen die deze documenten discursief gekleurd hebben, belichten.

Kernbegrippen in richtinggevende documenten 1945 - 2014

1945 - 1965 Het grijze boekje. De wet- en regelgeving op het gebied van kunst en cultuur leidde in de eerste helft van de twintigste eeuw nog niet tot enige financiële ondersteuning van de toneelsector; pas na de Tweede Wereldoorlog wordt die voor het eerst gegeven (Maanen, 1997). Voor het theater werd na de oorlog voor het eerst een en ander beleidsmatig vastgelegd in Ontwerp voor een regeling van het toneel na de oorlog (Defresne et al., 1944), vanaf 1946 beter bekend geworden als het Het grijze boekje. ${ }^{179}$ Er werd na 1945 niet als vanzelf aangenomen dat alle kunst en cultuur 'schoon' was en dus goed, en dat de totale Nederlandse bevolking daarvan diende kennis te nemen. Er werd uitgegaan van de traditionele schone kunsten, die werden als goed beschouwd. Aan deze goede kunsten werden beschavende en opvoedende eigenschappen toegedicht, ook aan de toneelkunst, zo mogen we lezen in Het grijze boekje. De functie van toneel werd daarin omschreven als:

'(...) het dienen van de geestelijke ontwikkeling van het volk, zij het in het voortbrengen en onderhouden van verscheidenheden, zij het in het ondersteunen en hechter maken ener eenvormigheid van denken en voelen, al of niet in religieus verband, mits deze eenvormigheid principieel in de volksziel leeft en groeit' (Defresne et al., 1944, p. 60).

De term volksziel in dit citaat uit 1944 is interessant. Blijkbaar ging men er op dat moment vanuit dat er zoiets bestond als één nationale eigenheid, of die nu bestond uit het koesteren van verscheidenheden van al of niet religieuze aard, of uit het verstevigen van eenvormigheid. Aandacht voor de volkseigen aard van groepen of van een gehele bevolking was voor dat moment niet nieuw maar had door de opkomst van het nationaalsocialisme in Europa een extra lading gekregen. Daarvoor, in 1918, werd in het Gereformeerd Theologisch Tijdschrift op geheel andere gronden dan die welke

\footnotetext{
${ }^{179}$ Ontwerp voor een regeling van het toneel na de oorlog (Defresne et al., 1944). Dit ontwerp werd nog tijdens de oorlog, in de illegaliteit, geschreven door de Commissie van Vijf, bestaande uit Guus Defresne, Ben Groeneveld, Hans van Meerten, Adolf Rijkens en Fred Sterneberg. Enkele jaren later werd het document besproken met meerdere Nederlandse toneelleiders en in een bescheiden oplage openbaar gemaakt. Het lag aan de basis van het eerste naoorlogse theaterbeleid van de Nederlandse overheid.
} 
de nazi's later zouden hanteren, de studie van de volksziel al bepleit voor mensen die ambtelijke arbeid verrichtten. Verrassend vrijzinnig werd hier zowel gewezen op de religieuze als de lokale eigenheden van mensen waarmee rekening gehouden diende te worden (Hoekstra et al., 1919).

Toneel was voor de oorlog aan de vrije markt overgelaten als vermaak voor een breed publiek, met voor een deel serieuze en voor een ander deel volkse segmenten. In tegenstelling tot de muzieksector, die ook vóór de Tweede Wereldoorlog al een zuilgestructureerd actief spreidingsbeleid van de overheid kende, werd toneel in die tijd artistiek niet hoog aangeslagen. De auteurs van Het grijze boekje spraken herhaaldelijk hun afschuw uit over de Nederlandse toneelpraktijk van voor de oorlog, waarin theater uitgevoerd en georganiseerd werd als bedrijf. Toneelleiders van dergelijke bedrijfsmatig opererende gezelschappen werden met bijna onverholen afschuw geen artistiek leiders maar exploitanten genoemd. ${ }^{180} \mathrm{Er}$ werd in scherpe bewoordingen afstand genomen van de praktijken van deze exploitanten en van de laisser faire-houding van diegenen die zich om het toneel zouden moeten bekommeren:

'Inderdaad, men was volkomen onverschillig en de angstvallig beschermde vrijheid gaf vrij spel aan de vulgaire speculaties op de wansmaak van een naar laag genot zoekend publiek, terwijl de geestelijke kernen zich machteloos hadden afgewend, de alle-lagen-des-volks-bindende functie van het toneel verloochenden en zich verscholen in eigen kringen, onder de leus van de beroemd geworden slagzin: soevereiniteit in eigen kring. Zij, die het toneel zouden moeten zien als een noodzakelijke geestelijke functie, lieten het wanhopig worstelen. En helaas, wanneer het in die strijd verloor, werd het des te erger verketterd, ondanks alle goede pogingen van particuliere zijde.(...) Wanneer een natie het nodig oordeelt voor zijn groei en instandhouding cultuur als een levensvoorwaarde te stellen, mag hij zich niet onttrekken aan een reële steun voor de kunst' (Defresne et al., 1944, p. 14).

Op deze manier werd gesteld dat het waardevolle en beschavende toneel dat gekoesterd diende te worden, ernstig in de steek was gelaten door de overheid en de 'geestelijke kernen', wat ik opvat als de verzamelde Nederlandse intelligentsia van die tijd en de toen nog invloedrijke religieuze organisaties. Het toneel was overgelaten aan de commercie en daardoor aan vulgariteit, zo werd gesteld. Er werd vanaf dat moment een sterk pleidooi gehouden om de exploitanten de artistieke leiding van toneelgezelschappen te ontnemen. Het plan steunde op twee gedachten: ten eerste

\footnotetext{
${ }^{180}$ In Het grijze boekje, een document van 133 pagina's, komt het woord exploitant in diverse combinaties 78 keer voor en het woord bedrijf 58 keer, in alle gevallen in negatieve zin.
} 
moest de commerciële basis van toneel verdwijnen en ten tweede moest het Nederlandse toneel vrij zijn en gedifferentieerd. De hergroepering van de toneelwereld moest hiervan een afspiegeling zijn en het herstel inluiden van zijn natuurlijke groei en cultuurhistorisch verband (Defresne et al., p. 58). Een nieuw discours begon zich af te tekenen. Twee opvattingen over de rol van kunst en cultuur kwamen tegenover elkaar te staan. De vooroorlogse podiumkunstensector en de opkomende populaire cultuur werden aan de ene kant gezien als een op publiek entertainment gericht commercieel vakgebied, waartegen aan de andere kant de beschavende werking van duizenden jaren oud westers cultureel erfgoed verdedigd diende te worden. De groeiende vrijheid van het individu in de wederopbouwperiode om zijn eigen vermaak vorm te geven stond tegenover het streven van de overheid om voor de gehele gemeenschap een 'goed en beschaafd' leven te waarborgen.

Wat opvalt aan het plan is dat voor het eerst een lans wordt gebroken voor de toneelkunst als betekenisvolle factor in het Nederlandse culturele leven. Het eerste hoofdstuk van Het grijze boekje heette 'Enkele opmerkingen over het toneel in verband met de samenleving'. Er werd dus een rol geformuleerd voor het toneel voor de gehele Nederlandse samenleving. Voor de argumentatie werd verwezen naar de wortels van de westerse theatertraditie in het Griekenland van de vijfde en vierde eeuw voor Christus en naar de rol van het theater bij de kerstening van Europa in de middeleeuwen. De schrijvers stelden zichzelf daarbij fundamentele vragen: hoe staat de Nederlander tegenover het toneel? Hoe is de verhouding van de Nederlandse beschaving tot het toneel? Wat is de werkelijke functie van toneel voor een natie, voor een samenleving, voor een volk? Men concludeerde dat 'de Hollander' spreekwoordelijk geen gevoel had voor toneel. Alleen het 'onbeschaafde deel mocht vanouds graag een gepeperde klucht zien' (Defresne et al., 1944, p. 10). Psychologisch gezien, zo dacht men, zou het Nederlandse volkskarakter zich niet kunnen uitdrukken in meer serieuze dramatische vormen en er daarom ook minder behoefte aan hebben. De praktijk van het platte consumptietoneel als commercieel vermaak was een van de redenen dat de kerkgemeenschappen in Nederland en hun politieke partijen zich al sinds jaar en dag uitspraken tegen het van overheidswege ondersteunen van toneel (Defresne et al., 1944, p. 10). Uiteindelijk deden de schrijvers voorstellen om te komen tot een drie- tot vijftal nieuw te formeren grote, landelijk opererende toneelgezelschappen onder een koepel van een centraal toneelorgaan dat hun belangen zou moeten gaan dienen. Er zou sprake moeten zijn van zowel een 'repertoiretheater' als van een 'volkstoneel'. Tekenend voor de periode is dat de beschouwingen in Het grijze boekje over de plannen voor het volkstoneel vijf en een halve pagina besloegen van het totale document van 133 pagina's. Hoe uitnodigend en inspirerend geformuleerd ook, de omvang van de passages over het volkstoneel toont 
dat het in 1945 niet anders dan als volkomen ondergeschikt aan het kunsttoneel gekwalificeerd kon worden.

De naoorlogse geschiedenis van het Nederlandse gesubsidieerde theater en de legitimering ervan ontrolden zich snel vanuit dit zuilgecontroleerde beschavingsoffensief tegen de commerciële verwildering van de goede zeden. Er werd gestreefd naar de landelijke spreiding van hoogstaand canoniek toneelrepertoire onder zo professioneel mogelijke omstandigheden. Dit streven werd gekoppeld aan de ambitie om dit repertoire toegankelijker te maken voor de gehele bevolking, als onderdeel van een beoogde volksverheffing in algemene sociaal-culturele zin. $\mathrm{Na}$ enkele decennia ging dit over in het streven om binnen een smallere opvatting van een specifiek cultuurbegrip kunst en cultuur te conserveren en te ontwikkelen. Het cultuurbeleid werd steeds minder aangestuurd vanuit levensbeschouwelijke zuilen en steeds meer vanuit een nationale zorg voor kunst en cultuur als merit goods. ${ }^{181}$ Het belang van kunst en cultuur werd gelegitimeerd als een onderdeel van het algemeen welzijn (Ministerie van CRM, 1972, p. 30). De legitimatie van overheidssteun aan cultuur 'verhuisde' zo tussen 1945 en 1965 geleidelijk van staatszorg voor de schone kunsten om culturele verwildering tegen te gaan en de bevolking beschaving bij te brengen, via gericht specifiek kunst- en cultuurbeleid als vormend nationaal belang, in de richting van de opvatting dat kunst en cultuur tot een breed sociaalmaatschappelijk welzijnsbegrip gerekend moesten worden. Als onderdeel van dit welzijnsbegrip zou kunst opgevat gaan worden als middel om de beschaving anders te zien dan voorheen. Beschaving kon steeds vaker meerduidig worden uitgelegd (Maanen, 1997, p. 125). Een in dit verband veelzeggende verschuiving op de golven van de toenmalige tijdgeest vond plaats in 1965. In dat jaar verhuisden de kunsten van het in 1918 ingestelde Ministerie van Onderwijs, Kunsten en Wetenschappen naar de opvolger van het Ministerie van Maatschappelijk Werk, dat voortaan verder ging als Ministerie voor Cultuur, Recreatie en Maatschappelijk Werk, met Marga Klompé (KVP) als een van de eerste ministers. ${ }^{182}$

1965 - 1982 De nota Kunst en kunstbeleid (1976) en de Nota Toneelbeleid (1976). Het rumoerige einde van de jaren zestig en de voor het Nederlandse theater zo belangrijke Aktie Tomaat in 1969) leidden tot de legitimering van een vernieuwings- en hervormingsdoctrine vanaf het begin van de jaren zeventig (Meyer, 1994). De Aktie Tomaat keerde zich tegen de bestaande toneelpraktijk, die naar haar mening slechts voor een kleine elite functioneerde en in het geheel niet bijdroeg aan sociale spreiding

\footnotetext{
${ }^{181}$ In Van Dale worden merit goods als volgt omschreven: 'diensten of goederen die de overheid zo nuttig vindt, dat zij het verstrekken ervan door middel van subsidies wil aanmoedigen' (Van Dale, 1999).

${ }^{182}$ In 1982 werd dit ministerie bij een reorganisatie van de overheid ontmanteld.
} 
(Pots, 2002, p. 311). Ligthart stelt het in 1988 in zijn analyse van het Nederlandse toneelbeleid nog scherper:

'De nieuwe generatie tonelisten is van mening, dat het vermolmde Nederlandse toneel moet kiezen voor maatschappelijk engagement. Toneel mag niet alleen tijdverdrijf voor de bourgeoisie zijn, maar kan bredere bevolkingslagen bewust maken van hun achtergestelde situatie. De toneelgezelschappen moeten zich betrokken voelen met die publieksgroepen, die door het verkalkte sterrensysteem buiten het theater worden gehouden. Een dergelijk engagement zal dan vanzelf resulteren in artistieke vernieuwing' (Ligthart, 1988, p. 12).

Kunst en dientengevolge ook theater diende voortaan maatschappelijk relevant te zijn, liefst in een directe verbinding met de dynamiek in de samenleving. Al in 1968 formuleerde Klompé als uitgangspunt van haar beleid als minister van Cultuur, Recreatie en Maatschappelijk Werk (CRM) dat zij het als haar taak zag om 'de kunstenaar en zijn kunst in contact met de samenleving te brengen...' (Pots, 2002, p. 294). ${ }^{183}$ Klompé-biograaf Gerard Mostert citeert in 2011 een tekenende uitspraak van haar uit een interview in het Algemeen Handelsblad van 23 november 1968:

'Wij moeten nieuwe, ook revolutionaire ideeën de gelegenheid geven tot ontwikkeling te komen. In die gekke wereld van ons is het van betekenis dat de hele sector van de kunsten kansen krijgt (...) De kunstenaar moet op de deur van de samenleving kunnen kloppen en roepen: hé mensen, het gaat de verkeerde kant op. Wat hij te zeggen heeft zal de ene keer verblijden, de andere keer choqueren. Die functie heeft de kunstenaar' (Mostert, 2011, p. 414).

Het legendarische Werkteater kreeg van de minister vanaf 1 september 1970 subsidie uit de experimentenpot om onderzoek te doen naar noodzakelijk geachte nieuwe vormen van toneelspelen. Het gezelschap bouwde zijn repertoire op door voor zijn voorstellingen en films zelf onderzoek te doen naar misstanden in bijvoorbeeld de gezondheidszorg, in de psychiatrie of in sociaal zwakkere wijken. De essentie van de koers van het gezelschap was: 'oog en oor hebben voor de positie van de gedepriveerde medemens' (Maanen, 1997, p. 145; Ogden, 1987; Schayk, 2001). Lid van het Werkteater van het eerste uur Shireen Strooker zegt in een interview voor de documentairereeks Allemaal Theater (Ditshuyzen, 2004) over dit besluit:

\footnotetext{
${ }^{183}$ Dr. Marga Klompé (wis- en natuurkundige), lid van de Katholieke Volks Partij (KVP), was minister van CRM in de centrumrechtse kabinetten Zijlstra (1966-1967) en De Jong (1967-1971).
} 
'Marga Klompé heeft met de subsidie die ze gegeven heeft, eigenlijk een heel verlicht besluit genomen. Ze heeft gezegd: Jullie krijgen een jaar (...) subsidie. Dat eerste jaar hoeven jullie geen voorstellingen te geven. Kijk, dát is de coup geweest!' (Mostert, 2011, p. 425).

Met de term coup verwijst Strooker naar het beladen moment van de toekenning van subsidie voor onderzoek en experiment en de vergaande gevolgen die Klompés besluit daarop kreeg voor de Nederlandse podiumkunsten in de daarop volgende decennia. In de brief waarin de minister haar besluit kenbaar maakte aan het Werkteater, schrijft ze letterlijk:

'Verder kan ik u berichten dat ik u uitzonderingsgewijs geen voorwaarden zal stellen ten aanzien van het aantal te spelen voorstellingen. Wel meen ik de verwachting te mogen uitspreken, dat u uw producties zoveel mogelijk zal vertonen en dan verspreid over de verschillende delen van het land' (Mostert, 2011, p. 425).

Klompé zette met de woorden 'dat ik u uitzonderingsgewijs geen voorwaarden zal stellen ten aanzien van het aantal te spelen voorstellingen' in feite de toon voor een periode van een nieuw soort legitimering van overheidssteun aan de kunsten. In het discours werd een andere machtsverhouding zichtbaar. In Het grijze boekje werd gesproken door de bestuurlijke elite over een te verheffen volk; het volk had zelf nauwelijks inbreng en werd bevoogd. Ten tijde van Klompé kwam het volk of, in de terminologie die in de veranderende politiek-maatschappelijke verhoudingen meer gangbaar werd, de maatschappij als actor centraler te staan. In plaats van beschavingsstrategieën op basis van de canonieke schone kunsten werd vanaf 1970 door de overheid ingezet op het experiment, de vernieuwing en de ontwikkeling van het toneel (Mostert, 2011, p. 425).

Wat er met het Werkteater gebeurde was exemplarisch voor een groot aantal kleine, professionele theatergezelschappen. In de slipstream van deze vernieuwingen ontstonden genres met benamingen als het vormingstoneel, jeugdtheater, margetheater, experimenteel toneel, muziektheater, bewegingstheater, beeldtheater en politiek theater; het waren verzamelnamen voor minder traditioneel esthetisch gerichte theatervarianten met vaak politiek geëngageerde doelstellingen. Deze gezelschappen stelden in buurthuis, fabriek of school, op festivals of in schouwburgzalen arbeidsverhoudingen, achterstelling en onderdrukking aan de kaak, of ontwikkelden nieuwe speelstijlen en grensverleggende theateresthetiek. (Maanen, 1997; Pots, 2002; Dulken, 2002; Lehmann, 1999; Krans, 2005). Solidariteit was daarbij een richtinggevend begrip. Theater dat zich profileerde als maatschappelijk relevant en 
vernieuwend, kon over het algemeen rekenen op steun door de diverse overheden met een in die tijd overwegend linkse signatuur. Theater dat gekenmerkt kon worden als commercieel entertainment, werd krachtig afgewezen evenals het in de ogen van velen burgerlijk gevonden kritiekloze literair dramatische repertoiretheater: '(...) ook naar het Grote Repertoire of de Deftige Wereldliteratuur verlangden deze theaterbezoekers niet bijzonder hevig' (Mostert, 2011, p. 423).

Klompé gaf eind jaren zestig het startschot, tegen de over het algemeen cultureel behoudende richting van haar eigen partijgenoten in, voor een cultuurbeleidsmatig innovatief tijdperk. Maar met haar persoonlijke betrokkenheid bij de sector en haar veelgeprezen tolerantie voor het vreemde en het andere dat zich in een roerige tijd aandiende, was het Nederlandse cultuurbeleid als geheel nog allerminst formeel geregeld. Onder haar opvolger, minister Piet Engels (KVP), verscheen in 1972 de Discussienota kunstbeleid. (Ministerie van CRM, 1972). In de geest van de tijd was dit geen gewone beleidsnota maar een discussiestuk. Men poogde recht te doen aan het groeiende besef dat besluitvorming niet meer van bovenaf diende te worden opgelegd, maar voorafgegaan diende te worden door brede maatschappelijke discussies over doelstellingen van overheidsbeleid ten aanzien van de kunsten (Pots, 2002, p. 297). Uit de conclusies van deze nota:

'Wil kunst werkzaam zijn, dan zal zij dus een maatschappelijke verschijning moeten bezitten, zich kunnen en moeten differentiëren in overeenstemming met de maatschappelijke differentiaties, deze volgend en tegelijk daaraan mede vormgevend. Tussen kunst en samenleving moet derhalve een diepe en fundamentele relatie bestaan, die als doelstelling voor elk kunstbeleid moet worden aanvaard. Daarmee is tegelijk gesteld dat een kunstbeleid noch alleen maatschappelijk noch alleen artistieke doeleinden kan hebben. Het moet als het ware meer gericht zijn op het te voorschijn roepen van de wisselwerking tussen kunst en samenleving, op welk niveau dan ook, dan op het oproepen van maximale prestaties' (Ministerie van CRM, 1972, p. 28-29).

Vier jaar later verscheen, op de vleugels van het linkse kabinet Den Uyl, een eerste echte beleidsnota, de Nota Kunst en kunstbeleid (Ministerie van CRM, 1976a). De nota kwam tot stand onder verantwoordelijkheid van de minister van CRM, Harry van Doorn. ${ }^{184}$ De drie belangrijkste uitgangspunten van het kunstbeleid werden daarin als volgt geformuleerd:

1. Het ontwikkelen en in stand houden van culturele waarden

2. Het toegankelijk maken van culturele objecten en manifestaties

\footnotetext{
${ }^{184}$ Van Doorn behoorde tot de progressieve Politieke Partij Radicalen [PPR]. Een groene, progressieve en aanvankelijk christelijke politieke partij. De kleine partij is later opgegaan in Groen Links.
} 
3. Het bevorderen van de mogelijkheden voor de bevolking om in culturele waarden te participeren (Ministerie van CRM, 1976a, p. 13)

Op basis van de Nota Kunst en kunstbeleid werden per sector deelnota's geschreven met vertalingen van deze algemene beleidsuitgangspunten in sectorale beleidsdoelen. In 1976 kwam zo de sectorspecifieke Nota Toneelbeleid (Ministerie van CRM, 1976b) uit. Overigens werden de concrete voorstellen in deze nota om het bestel te herijken uiteindelijk niet uitgevoerd omdat er te veel weerstand was in de Tweede Kamer en in de toneelwereld. In feite werd in deze nota verwoord wat in de eraan voorafgaande periode belangrijk gevonden werd voor de relatie tussen theater en samenleving. De nota bracht de actuele theaterwereld van dat moment in kaart (Maanen, 1997, p. 232). Hij ademde de emancipatoire geest van de periode 19691976, met accenten op formuleringen als 'participatie', 'culturele waarden', 'niet alleen volgen maar ook op actieve wijze sturen', 'aanbod' en 'vormingstoneel', in plaats van terminologie ontleend aan de 'schone kunsten'. Over het algemeen sprak uit de nota respect voor culturele verschillen. De overheid leek vanaf dat moment formeel uit te gaan van de pluralisering van haar waardesysteem.

In de Nota Toneelbeleid werden tevens bijzondere nieuwe bestuursafspraken gemaakt tussen de verschillende overheidslagen van het Rijk, de provincie en de gemeenten. Op basis van een nieuw onderscheid tussen open aanbod (canoniek westers repertoire en ontwikkelingstheater) en gericht aanbod (verschillende varianten van vormingstoneel) kwam de verantwoordelijkheid voor het vooral artistiek aangestuurde traditionele canonieke toneelaanbod te liggen bij het Rijk, en de verantwoordelijkheid voor de later vaak met doelgroepentoneel aangeduide sector bij de lagere overheden. De Nota Toneelbeleid (Ministerie van CRM, 1976b) is een document van 87 pagina's. Het begrip vormingstoneel komt er 62 keer in voor; aanbod 129 maal en maatschappelijk 41 maal.

De nota lezend kan niet anders dan geconcludeerd worden dat er tussen de regels door naar een oplossing gezocht werd voor een ideologisch probleem. In het vormingstoneel met zijn over het algemeen sterk polariserende politieke lading school een dubbelzinnigheid, zo concludeerde men in de nota. Het vormingstoneel eiste op basis van democratische beginselen subsidiëring op als verworven recht binnen een maatschappelijke ordening die men in feite afwees. Tevens werd door toenmalige vormingstoneelgroepen zoals het roemruchte Proloog uit Eindhoven, de gangbare toneelwereld afgewezen als te zeer ingebed in de gevestigde burgerlijke cultuur. Voor deze gezelschappen was de gevestigde theatercultuur daarmee eveneens onacceptabel (Ministerie van CRM, 1976b, p. 6). ${ }^{185}$ Door nu de verantwoordelijkheid voor de dicht op hun doelgroepen opererende gezelschappen te leggen bij plaatselijke

\footnotetext{
${ }^{185}$ Proloog wordt met naam en toenaam genoemd in de nota.
} 
overheden, verschoof de Rijksoverheid in feite het probleem maar elimineerde het daarmee allerminst. De problemen tussen weerbarstige gezelschappen en hun lokale, cultureel vaak conservatieve overheden werden er alleen maar groter door. Op het eind van de jaren zeventig groeide door deze versnippering en polarisatie van het theater (en de rest van de kunstenwereld) de afstand tussen drie discursieve werelden, draaiend rondom dezelfde materie. Ten eerste de emancipatoir ingestelde sociaaldemocratische politici van de kabinetten Den Uyl, die cultuurparticipatie in wensten te zetten om het individu en daarmee de gehele samenleving te emanciperen. Ten tweede de steeds beter georganiseerde, politiek geëngageerde kunstenaars, die hun artistieke zowel als hun politieke autonomie te vuur en te zwaard verdedigden op basis van democratische dan wel revolutionaire 'rechten'. Ten derde het overgrote deel van de bevolking, het publiek, dat uiteindelijk meer en meer ging kiezen voor de groeiende mogelijkheden van commercieel aanbod en populaire cultuur.

Met het gewicht dat de sociale legitimatie van kunstsubsidies in de jaren zeventig kreeg, groeide bij kunstenaars de behoefte om hun artistieke autonomie te verdedigen. Het maatschappelijk gewicht van de gesubsidieerde theatersector nam onder andere hierdoor steeds verder af tot zich een merkwaardige paradox aftekende. Eind jaren zeventig en begin jaren tachtig bleek het professionele gesubsidieerde theaterleven als nooit tevoren te bloeien in kringen van experts en ingewijden, terwijl de publieke belangstelling voor dit alles dramatisch terugliep (Pots, 2002, pp. 312313). ${ }^{186}$ Er was sprake van versnippering en fragmentatie van het aanbod op basis van een subsidiestelsel dat beargumenteerd ruimte gaf aan artistieke en politiek geëngageerde autonome theatergroepen en hun kleine deelpublieken van min of meer ingewijden. Het Grote Publiek werd zo onbedoeld echter min of meer buitengesloten en ging in toenemende mate kiezen voor een wereldwijd voor velen meer herkenbare populaire cultuur van commercieel entertainment, publieksfilms en televisie, musical, pretparken en een internationale popcultuur (Swaan, 2008). Begin jaren tachtig trokken ambtenaren, experts en ingewijden aan de bel. Steeds openlijker werd er gesproken van een malaise in de gesubsidieerde toneelwereld.

\footnotetext{
${ }^{186}$ Ter vergelijking: in 1947 werden er vijf toneelgezelschappen door de Nederlandse overheid gesubsidieerd, in 1983 waren er dertig gesubsidieerde theatergezelschappen. In seizoen 1949/1950 was het aantal bezoeken aan beroepstoneel in Nederland 2.4 miljoen, in seizoen 1970/1971 waren dat er voor het gesubsidieerde toneel 1.3 miljoen en in 1983/1984 waren dat er nog 860.000 (Ligthart, 1988, pp. 124-129). Des te opmerkelijker omdat in dezelfde periode (1947-1980) de Nederlandse bevolking groeide van 9,6 miljoen naar 14,9 miljoen inwoners en in 1980 tevens veel hoger opgeleid was dan aan het eind van de jaren veertig. Opleidingsniveau wordt al decennialang gehanteerd als een van de parameters voor aard en intensiteit van cultuurdeelname (Ligthart, 1988; Broek, Haan, \& Huysmans, 2009).
} 
1982 - 1995. Eindrapport Commissie Landelijk Toneelbestel (1984) en Notitie Cultuurbeleid (1985). Het aantal en de variatie van gesubsidieerde theatergezelschappen en podia was vanaf midden jaren zeventig onder de beschreven condities sterk toegenomen. De in de loop der tijd fors gegroeide uitgaven aan subsidies op alle beleidsterreinen, vormden voor de overheid een nauwelijks te dragen last. In het kader van grote politieke koersveranderingen om deze 'uit de hand gelopen' overheidsuitgaven te beperken, werd voor het cultuurbeleid begin jaren tachtig een periode ingeluid waarin de belangrijkste beleidsdoelstelling werd: het verbreden van het maatschappelijke en financiële draagvlak voor kunst en cultuur en het terugdringen van de afhankelijkheid van de sector van de overheid (Dulken, 2002, p. 28; Pots, 2002; Maanen, 1997). Vanaf begin jaren tachtig werd er over het cultuurbeleid steeds vaker gesproken in termen van efficiëntie, doelmatigheid, effectiviteit en beheersbaarheid van overheidsuitgaven. Economische motieven en marketingstrategieën vonden hun weg naar de sector (Hoeven, 2005, p. 35). Van Dulken noemt dit 'ontstatelijking door economische stagnatie' (Dulken, 2002, p. 147).

Opmerkelijk hoe in het begin van de jaren tachtig na veertig jaar de toon van het debat 180 graden draaide: na de afkeer van de vooroorlogse 'exploitanten' wordt in het neoliberale klimaat het meer economisch denken over cultuur nieuw leven in geblazen. Deze omslag in het cultuurbeleid is niet alleen een kwestie van pure bezuinigingsdrift geweest. Het ging ook om een fundamenteel andere, centrumrechtse of neoliberale houding van de overheid ten opzichte van overheidssubsidies in het algemeen en om een volledige stelselherziening van het kunst- en cultuurbeleid in het bijzonder. In het cultuurbeleidsdiscours voerden technocratisch instrumentele argumenten nu de boventoon ten koste van meer ideologisch substantiële argumenten rond de noodzaak van kunst in het openbare leven. Op 2 mei 1984 komt het Eindrapport Commissie Landelijk Toneelbestel (Commissie De Boer, 1984) uit, het resultaat van het werk van de door minister Eelco Brinkman ingestelde commissie-De Boer die richting moest geven aan een herijking van het Nederlandse toneelbestel. ${ }^{187}$ De bevindingen van de commissie waren:

Ten eerste dat Nederland bezien diende te worden als één samenhangend beleidsterrein voor kunst en cultuur.

Ten tweede dat theatergezelschappen niet meer voor langere tijd als vanzelfsprekend gesubsidieerd konden worden. Er kwam een categorie van zes grote toneelgezelschappen die de continuïteit moesten waarborgen, ${ }^{188}$ en een categorie van kleinere gezelschappen die zowel voor driejarige periodes gesubsidieerd konden worden als voor incidentele producties.

\footnotetext{
${ }^{187}$ De commissie werd genoemd naar haar voorzitter, H.A. de Boer.

${ }^{188}$ Het ging hier om de gezelschappen Publiekstheater (Amsterdam), Haagse Comedie, Ro Theater (Rotterdam), De Voorziening (Groningen), Globe (Eindhoven) en Theater (Arnhem).
} 
Ten derde werd min of meer onontkoombaar geacht dat de verantwoordelijkheid voor toneelproductie bij het Rijk moest komen te liggen. Daar was een zogeheten vereveningsoperatie, ook wel reshuffelingsoperatie genoemd, voor nodig van overheidsgeld; er werd 14 miljoen gulden uit het provincie- en gemeentefonds overgeheveld naar het Rijk (Maanen, 1997, p. 234).

Ten vierde werd geadviseerd om jeugd- en jongerentheater dat niet voor grote zalen produceerde, onder verantwoordelijkheid van lagere overheden te plaatsen.

Ten vijfde moesten gezelschappen in staat worden gesteld om bedrijfseconomisch efficiënter te werken; beperkende voorwaarden rond het genereren van eigen inkomsten dienden te verdwijnen.

Voorts pleit de commissie voor het versterken van de relatie tussen het gesubsidieerde toneel en de media, daarmee vooruitlopend op intermediale ontwikkelingen die vanaf het begin van de jaren negentig in een stroomversnelling kwamen. De belangrijkste media waren toen nog radio en televisie en die werden gezien als mogelijkheden om 'nieuwe vormen van televisietoneel te ontwikkelen vanuit de voor het podium producerende gezelschappen' (Commissie De Boer, 1984, pp. 5-6). De adviezen van de commissie-De Boer werden door Brinkman in 1985 verpakt in zijn Notitie Cultuurbeleid en daarna werd het toneelbeleid erop gebaseerd.

Op het Eindrapport Landelijk Toneelbestel (Commissie De Boer, 1984) en op de Notitie Cultuurbeleid (Ministerie van WVC, 1985) werd door de theaterwereld over het algemeen gematigd positief gereageerd, terwijl het toch vooral technocratische rapporten waren over het veranderen en herijken van subsidieregels. Discursieve spanningen bleven er overigens, zoals door Brinkman werd onderkend in zijn Brief over het kunstbeleid van april 1987 aan de Raad voor de Kunst (Ministerie van WVC, 1987a). Daarin rept hij over drie dynamische spanningsvelden: aanbod versus afname, Randstad versus regio en de ene kunstdiscipline versus de andere. Ondanks de ogenschijnlijk betere condities door de longitudinale subsidieperiodes van vier jaar, wordt de rol van de overheid in het theaterbeleidsdiscours steeds meer gedomineerd door vragen rond het hoeveel en voor wie. Brinkman bouwde overigens wat algemene uitgangspunten betreft voort op Kunst en kunstbeleid (Ministerie van CRM, 1976a) en op de Nota Toneelbeleid (Ministerie van CRM, 1976b); hij zette zich er in ieder geval niet tegen af. Pots gebruikte waar hij schreef over de periode Brinkman de term enkele koerscorrecties voor deze beweging (Pots, 2002, p. 325). Wel benadrukte Brinkman het beperkte karakter van het beleidsterrein voor 'specifieke' cultuur. Cultuurbeleid behelsde aldus kunst, musea, monumenten en archieven, radio, televisie en pers, en internationale betrekkingen. Hij nam afstand van het bredere cultuurbegrip als onderdeel van een welzijnsideaal en van de toetsing van het belang van kunst aan het begrip maatschappelijke relevantie: 
'Op dit moment bestaat niet langer de neiging de betekenis van kunst, betekenis ook in maatschappelijke zin, primair te toetsen aan het begrip «maatschappelijke relevantie». Die term is naar veler gevoelen te zeer getekend door de uitgesproken maatschappijhervormende opvattingen van een decennium en langer geleden, opvattingen die in een aantal opzichten op onderdelen vruchtbaar kunnen zijn geweest maar die haast onvermijdelijk moesten leiden tot nieuwe stellingnames' (Ministerie van WVC, 1985, p. 8).

Hij positioneerde kunst weer in het rijtje filosofie, religie en wetenschap, en bracht daarmee naar eigen zeggen, kunst en cultuur direct in verband met de kwaliteit van het bestaan. Uit de nota spreekt de notie van een pluriform samengestelde Nederlandse gemeenschap en dus van een culturele pluriformiteit (Maanen, 1997, p. 240). Brinkman is hierover weinig concreet, maar spreekt over bevolkingsgroepen met ieder een eigen culturele beleving. Voorts werd duidelijk geformuleerd dat het primaat voortaan zou komen te liggen bij het kwaliteitsbeginsel, niet elk initiatief zou alleen op basis van de geldende beleidsregels zonder meer geld tegemoet kunnen zien. Hij specificeerde zijn kwaliteitsbegrip als volgt:

'Kwaliteit [is] hierbij niet op te vatten als iets statisch, als een norm die bij voorbaat vastligt, maar meer als een richtsnoer voor het niveau waarnaar gestreefd moet worden. Kwaliteit op verschillende niveaus en van verschillende aard, maar steeds getoetst over de grenzen van sectoren aan meer algemene opvattingen met betrekking tot kwaliteit, waarbij het gaat om onder andere zeggingskracht, oorspronkelijkheid en ambachtelijk kunnen. Deze toetsing, zoal niet aan objectieve dan toch aan intersubjectieve kwaliteitsnormen, heeft op den duur iedere sector nodig om werkelijk tot ontwikkeling te komen. Dit impliceert een voortdurende discussie, die, zo is in het verleden vaak genoeg gebleken, niet altijd even gemakkelijk zal verlopen' (Ministerie van WVC, 1985, p. 7).

Deze formuleringen zijn op te vatten als indicatief voor het discours. Kwaliteit, zeggingskracht en ambachtelijk kunnen zijn termen die door de verschillende actoren op verschillende wijzen werden geïnterpreteerd. Brinkman zelf onderkende in zijn schrijven de strijd zoals die in de kunsten geleverd werd, als hij stelt dat het nieuwe, het niet gevestigde, snel geneigd zal zijn te roepen dat het niet voldoende kansen krijgt, omdat het gevestigde zijn belangen het meest effectief weet veilig te stellen' (Ministerie van WVC, 1985, p. 7). Uit de hierna volgende passage uit Brinkmans notitie blijkt de keuze die gemaakt werd voor een kunstenaarsbeleid, door bij subsidiëring nagenoeg eenduidig uit te gaan van de aanbodgedachte, waarbij de minister zich direct indekte tegen uitwassen die blijkbaar werden waargenomen in de periode 
voorafgaand aan zijn bewind. Hieruit is af te lezen dat er overduidelijk discursieve frictie bestond over de legitimiteit van overheidssubsidies aan bepaalde kunstvormen die aan iedereen ten goede moesten komen en de manier waarop daar door kunstenaars zelf vanuit een aanspraak op autonomie en strevend naar exclusiviteit volkomen anders over gedacht werd.

'De ervaring leert dat het oordeel en de belangstelling van het grote publiek niet altijd een zuivere graadmeter vormen voor de waarde van bepaalde kunst- en cultuuruitingen. Daarom kan het nodig zijn dat kunstenaars, kunstwerken, maar bij voorbeeld ook bepaalde televisieprogramma's de kans krijgen zich te bewijzen tegen de onverschilligheid of misschien zelfs aanvankelijke afwijzing van het publiek in. (...) De hierboven omschreven opvatting wordt wel aangeduid als de aanbodgedachte en is te beschouwen als één van de pijlers van het kunst- en cultuurbeleid. (...) Tevens echter ben ik van mening dat er reden is kritisch te kijken naar de mate waarin op deze aanbodgedachte een beroep wordt gedaan. Dit, omdat het aanvaarden van de aanbodgedachte niet betekent dat de kunsten cultuursector ontslagen is van de verplichting om met de factor van de publieke belangstelling rekening te houden en deze waar mogelijk te vergroten. (...) Als ooit in ernst verdedigd is dat juist het uitblijven van respons van de zijde van het publiek beschouwd diende te worden als zekere indicatie voor kwaliteit, en dus als grond voor subsidiëring vanwege de overheid, dan ligt die tijd nu wel definitief achter ons. Deze opvatting was stellig ingegeven door de wens om wanneer men zich met kunst en cultuur bezighield, men verder geen verantwoordelijkheid af te hoeven leggen tegenover wie dan ook' (Ministerie van WVC, 1985, p. 17).

Deze formuleringen vormen het afscheid van de vorige periode. Er werd actief ingegrepen om de discrepantie te lijf te gaan tussen het overheidsstreven om cultuur toegankelijk te maken en de gesloten wereld van artistiek autonome theaterkunstenaars. Tegelijkertijd werd een vorm van kunstenaarsbeleid min of meer voortgezet met het promoten van wat voortaan topkunst zou gaan heten. Na deze openingszetten door Brinkman aan het begin van een ideologisch anders gekleurde periode dan die van de jaren zestig en zeventig, werd vanaf 1988 ingezet op een nieuw en ingrijpend veranderd subsidiestelsel met langere looptijden. Het ging nog steeds overwegend niet over het waarom maar vooral over het hoe en hoeveel. Na het min of meer als proef gelanceerde Plan voor het kunstbeleid 1988-1992 (Ministerie van WVC, 1987b) werd vanaf 1992 structureel gesubsidieerd op basis van de zogeheten cultuurnotasystematiek: om de vier jaar werden alle gesubsidieerde gezelschappen, sectorinstituten en koepelorganisaties tegen het licht gehouden om vervolgens al of 
niet voor vier jaar gesubsidieerd door te kunnen werken. ledere vierjaarlijkse periode werd gekenmerkt door een combinatie van de kleur van de tijdgeest, de stand der dingen in de artistieke praktijk en de politieke wind van het moment.

Er hebben zich sinds 1992 vijf vierjarige cultuurnotaperiodes ontrold met elk hun tijdgebonden discursieve kleuren. Minister Hedy d'Ancona (1992-1995) ${ }^{189}$ vertaalde de tijdgeest in het begin van de jaren negentig in beleid met de veelzeggende 15 procentregeling. Door deze maatregel werden gezelschappen gedwongen 15 procent van hun inkomen te genereren door eigen inkomsten. Het verlaten van de strikte aanbodgedachte, ofwel het denken in markttermen, kreeg zijn vaste plek binnen de kunstensector. De staatssecretarissen Aad Nuis (1996-1999) en Rick van der Ploeg (2001-2004) bouwden dit strategisch en marktgericht denken uit en maakten werk van de mogelijkheden waarmee de overheid het aanboren van nieuw cultuurpubliek kon aanjagen. Van der Ploegs uitgangspuntennota Cultuur als confrontatie (Ministerie van OCW, 1999b) werd verder gekenmerkt door opmerkelijk veel ruimte voor diverse culturen van allochtone Nederlanders, voor een zich ontrollende urban culture en voor digitale media in een technologische cultuur. ${ }^{190}$ Allochtonen en jongeren werden in cultuurbeleidstermen niet meer voornamelijk als probleem gedefinieerd, wat voordien vaak gebeurde omdat als vanzelfsprekend verondersteld werd dat ze niet deelnamen aan kunst en cultuur. Zij werden nu gezien als kansen en hun cultuurbeleving als een mogelijke verrijking voor het culturele leven. Opmerkelijk daarbij is dat daartegenover stond dat in dezelfde periode de Raad voor Cultuur over veel vrouwelijke theatermakers negatief adviseerde, zo stelde Het Netwerk voor vrouwelijke theatermakers in een pamflet van september 2000, onder anderen ondertekend door Krizstina de Châtel, Mieke Kolk, Lidwien Roothaan en Annemarie Prins. Ze wezen erop dat de destijds gekende gezelschappen Axis, Bonheur, Caroussel, Independance en het filmcollectief Cinemien dreigden te verdwijnen (Netwerk, 2000). Het leek erop alsof de overheid onder verantwoordelijkheid van Van der Ploeg de ene culturele minderheid (vrouwelijke theatermakers) inruilde voor andere (allochtonen en jongeren). Bij elke nieuwe cultuurnota voor vier jaar ontstond er reuring en herhaalden zich dezelfde patronen: het traditionele en gevestigde roerde zich over gemaakte subsidiekeuzes en stond daarin tegenover het nieuwe en explorerende. Totdat op basis van groeiende onvrede vanaf het midden van de jaren negentig in en buiten de kunstenwereld er langzaam consensus begon te ontstaan over de noodzaak tot fundamenteel ingrijpen in de subsidiesystematiek van de overheid.

\footnotetext{
${ }^{189}$ Hedy d'Ancona was van 1989 tot 1994 minister van Welzijn, Volksgezondheid en Cultuur in het kabinetLubbers III.

${ }^{190}$ In opdracht van Van der Ploeg werd door Michiel Schwartz een aparte deelnota van Cultuur als confrontatie geschreven over de rol van de overheid in relatie tot een steeds meer gemediatiseerde cultuur (Schwartz, 1999).
} 
1995 - 2012. Kunst van Leven; hoofdlijnen cultuurbeleid (Ministerie van OCW, 2007a). Staatssecretaris Medy van der Laan pakte vanaf 2003 de handschoen op. In haar beleidsbrief Meer dan de som van november 2003, die de aanloop zou vormen tot de cultuurnota voor de periode 2005-2008, schreef ze dat ze naar een herziening van het cultuurnotasysteem toe wilde, door minder bureaucratie en meer eigen verantwoordelijkheid voor de instellingen, meer samenhang en wisselwerking in het culturele leven en een versterking van de culturele factor in de samenleving (Ministerie van OCW, 2003, p. 3). In haar daaropvolgende uitgangspuntennota Verschil maken, Herijking cultuurnota systematiek van september 2005 schreef ze op de eerste pagina's:

'Samenvattend kun je stellen dat de cultuurnota systematiek als beheersinstrument ruimschoots voldoet, maar als beleidsinstrument is verschrompeld tot een verbureaucratiseerde en ontzielde procedure. Het politieke gesprek gaat nog slechts over de vraag of voldoende recht wordt gedaan aan Thorbecke' (Ministerie van OCW, 2005, pp. 1-3).

Op basis hiervan werd door overheid en sector ingezet op structurele hervormingen van de overheidsbemoeienis met kunst en cultuur. De drie belangrijkste beleidsdoelen voor de daaropvolgende jaren werden als volgt geformuleerd.

Doel een was het bewerkstelligen van een nieuw evenwicht tussen cultuur en politiek. Doel twee was het kantelen van het subsidiegebouw: er werd een ontwikkelingstraject gestart om een verschuiving mogelijk te maken van uitsluitend verticale subsidiecarrières naar horizontale perspectieven voor diverse vormen van artistieke praktijken. Het belang van het groeiende aanbod van andere dan traditionele cultuuruitingen werd onderkend en er werden voorstellen gedaan om dat in de toekomst meer te ondersteunen. Doel drie was het bewerkstelligen van meer inhoudelijk en minder procedureel samenspel tussen de bewindspersoon van het ministerie en de partners in de sector. Met de uiteindelijke hoofdlijnen voor cultuurbeleid in Kunst van Leven; hoofdlijnen cultuurbeleid en het bijbehorende Subsidieplan 2009 - 2012 beoogde de overheid een innovatieve agenda voor het Nederlandse cultuurbeleid te ontwerpen (Ministerie van OCW, 2007a).

De procedures van aanvraag, advies en besluitvorming van de cultuurnota voor de periode 2009-2012 verschilden aanzienlijk van die van voorgaande edities. In 2007/2008 werd een nieuwe cultuurbeleidsagenda voor de toekomst gepresenteerd door de inmiddels aangetreden minister van OCW, Ronald Plasterk (PvdA), in de vorm van de cultuurnota Kunst van Leven; hoofdlijnen cultuurbeleid (Ministerie van OCW, 2007a), in combinatie met het iets later openbaar gemaakte subsidieplan voor de periode 2009-2012. Het subsidieplan bestond uit twee delen: de Basis Infra Structuur 
(BIS) en het NFPK+ (Nederlands Fonds voor de Podiumkunsten). Het laatste kan gezien worden als een pragmatische fusie van een aantal bestaande overheidsfondsen voor cultuur tot één 'superfonds'. ${ }^{191}$

De uitvoerende podiumkunstgezelschappen in de BIS werden verdeeld in twee categorieën: een deel kreeg een zogeheten langjarig perspectief, een ander deel kreeg een vierjarig subsidieperspectief. In de BIS werden de volgende aantallen instellingen met een langjarig subsidieperspectief opgenomen: 29 musea, negen sectorinstituten, tien orkesten, twee dansgezelschappen en twee operagezelschappen. Als instellingen met een vierjarig subsidieperspectief werden opgenomen: negen toneelgezelschappen, vijf dansgezelschappen, negen jeugdtheatergezelschappen, een operagezelschap, een internationaal festival per discipline, de productiehuizen voor de podiumkunsten, de postacademische instellingen, ontwikkelfuncties, presentatieinstellingen beeldende kunsten en ondersteunende instellingen op internationaal, educatief en intercultureel gebied.

In de aanloop erheen en in het eerste jaar van dit nieuwe stelsel zijn er begrijpelijkerwijs in het culturele veld vragen gesteld over het hoe en waarom van deze categorieën. Waarom werd er bijvoorbeeld geen enkel toneelgezelschap in de categorie langjarig gedacht? (Horst \& Zoutman, 2010). Hoe werden film en media gepositioneerd, die toch belangrijke cultuursectoren waren in dit door beeldcultuur en mediatisering getekende tijdvak? Als er inhoudelijk gerefereerd werd aan de ons omringende werkelijkheid, dan was dat aan e-cultuur, medianetwerken, urban culture, hiphopopera's en sociale media. Maar hoewel dit sociaal-culturele belang werd gezien, vervulden deze sectoren alleen bijrollen in de vernieuwde subsidiestructuur. Slechts 'ondergeschikte' paragrafen in Kunst van Leven; hoofdlijnen cultuurbeleid (Ministerie van OCW, 2007a) verwezen naar de nieuwe culturele arena's. De discussie werd, voor zover het theater betrof, hoofdzakelijk gevoerd in artistieke termen rondom de traditionele canon van het westers repertoire, aangevuld met een terminologie die rond cultureel ondernemerschap hangt.

De instellingen die in de BIS werden opgenomen, leken daarin dan ook te zijn terechtgekomen vanuit een grote mate van overeenstemming over het landelijk culturele belang. Het theaterbeleidsdiscours werd weliswaar gevoed door termen als herstructurering, herijking van het bestaande, herallocatie van middelen, subsidieprocedures, effectiviteit, marketing, eigen bijdrage, ondernemerschap en marktwerking, maar het inhoudelijke belang en het artistieke bestaansrecht van deze

\footnotetext{
${ }^{191}$ In het NFPK+ werden opgenomen: Nederlands Fonds voor de Podiumkunsten; Programmafonds Cultuurparticipatie; Fonds Beeldende Kunst, Vormgeving, en Bouwkunst; Nederlands Literatuur productie en Vertalingfonds; Fonds voor de Letteren; Mondriaan stichting; Stimuleringsfonds voor Architectuur; en het Nederlands Fonds voor de Film.
} 
grote gevestigde instellingen werden niet bevraagd of in twijfel getrokken. Sterker nog, er kwamen theatergezelschappen op die schaal bij. ${ }^{192}$

De gehanteerde economische terminologie bij het herijken van de procedures is voor een deel rechtstreeks overgewaaid uit het bedrijfsleven. Sinds de jaren tachtig en negentig werd zij in Nederland frequent gebezigd in het kunstendiscours. Het gaat daarbij om meer dan alleen om retorische verschuivingen, zoals kunstsocioloog Pascal Gielen concludeerde in zijn State of the Union bij de opening van het Vlaamse Theaterfestival 2011 in Brussel:

'De re-articulatie van cultuurparticipant tot klant en die van kunstenaar tot creatief ondernemer kende er al evenmin noemenswaardige weerstand. Voor vermeende neutrale observatoren van het Nederlandse cultuurbeleid zoals de Boekmanstichting of zelfs een erudiet beleidshistoricus als Roel Pots, was er geen vuiltje aan de lucht wanneer ze in hun studies en publicaties het woordje 'beleidsondersteuning' of 'cultuursubsidie' inruilden voor de notie 'overheidsbemoeienis'. Met de omarming van dit jargon lieten ze uitschijnen dat cultuurzorg door de overheid geen noodzaak, maar een noodzakelijk kwaad is, een oneigenlijke marktcorrectie waarvoor men zich in feite een beetje moet schamen. (...) Woorden genereren een symbolisch universum dat ons samenleven ook werkelijk vorm geeft' (Gielen, 2011).

Dat woorden en uitdrukkingen daadwerkelijk het discours vormgeven, is een belangrijk uitgangspunt van dit hoofdstuk. Ik ben het dan ook eens met de formulering van Gielen: de economische terminologie heeft het recente Nederlandse cultuurbeleid niet alleen gekleurd maar ook daadwerkelijk gevormd. Het is goed om ons hierbij te realiseren dat de beleidshervormers in het kielzog van staatssecretaris Van der Laan in de eerste plaats de subsidiesystematiek wensten te reorganiseren. Het hervormingsproces was destijds aanvankelijk een technocratische operatie die erop gericht was om het bestaande stelsel te verbeteren.

Op de eerste pagina van Kunst van Leven; hoofdlijnen cultuurbeleid (Ministerie van OCW, 2007a, p.3) zet Plasterk uiteen waarom de Nederlandse overheid cultuur subsidieert. Hij geeft daar vier argumenten voor. Ten eerste is er het argument van het collectief goed. Collectieve goederen zijn goederen die moeilijk aan mensen te ontzeggen zijn en die niet rivaliserend zijn bij consumptie. Daarbij valt te denken aan een leger of aan dijken, maar ook aan bijvoorbeeld het Rijksmuseum of bepaald theaterrepertoire. In de tweede plaats is er het argument van de externe effecten.

\footnotetext{
${ }^{192}$ Met ingang van de nieuwe cultuurnotaperiode op 1 januari 2009 werden drie nieuwe gezelschappen in de grootste categorie operationeel: Toneelgroep Maastricht te Maastricht, De Utrechtse Spelen in Utrecht, en het Friese theatergezelschap Tryater in Leeuwarden.
} 
Hierbij vallen termen als internationale uitstraling, toerisme en effect op de economie. Deze twee argumenten wonnen snel terrein in de jaren tachtig en negentig, en raakten in een stroomversnelling na het wereldwijde succes van de creative class-theorieën van Richard Florida (Florida, 2002, 2005). ${ }^{193}$ Het argument van het externe effect stond lang op gespannen voet met het aanbodgestuurde kunstenaarsbeleid van de overheid. In de derde plaats is cultuur volgens Plasterk een merit good; het wordt zo gunstig geacht voor iedereen in de gemeenschap dat de overheid zich er minstens voor een deel garant voor zou moeten stellen. Het vierde en laatste argument is dat van de conservering van cultureel erfgoed.

Tijdens het invoeren van het nieuwe stelsel ontstond onduidelijkheid, bijvoorbeeld over de verschillen tussen de twee soorten 'vierjarigen', die in de BIS en die in het NFPK. Ook werd in de sector gesproken over een vermeende hiërarchie tussen culturele instellingen in de BIS en in het NFPK. Bij een evaluatie na anderhalf jaar bleek er van deze onduidelijkheden en misverstanden al veel verdampt te zijn en was er in vakkringen sprake van een gematigd optimisme over de uitkomsten van de hervormingsoperatie (Horst \& Zoutman, 2010). Hierbij moet aangetekend worden dat de hervorming van de subsidiesystematiek een vrijwel gesloten vakdiscours geweest is van theatermakers, politici, critici en andere experts en dat voor de grote theaterinstellingen van de BIS gold dat de beoogde verbetering van het publieksbereik van gesubsidieerd theater in feite nergens substantieel tot stand gekomen was. Ook binnen het NFPK was een aantal fricties in die eerste twee jaren nog niet uitgekristalliseerd, maar daar werd constructief aan gewerkt, zoals geconstateerd werd door beschouwende experts (Berg, 2011).

In de loop van 2010 dook door de electorale aardverschuiving in het Nederlandse politieke landschap een veel groter probleem op voor de theatersector dan men aanvankelijk had voorzien. Hiermee diende zich een ander soort hervormers aan dan die in de slipstream van Van der Laan en Plasterk. Daarmee werd een andere manier van beleidsmatig reageren op de vernetwerkte nieuwe tijd zichtbaar naast die van de geproclameerde hervormers van de cultuurnotasystematiek. De twee reacties kwamen openlijk met elkaar in botsing in de sociaaleconomische, culturele en politieke arena van de jaren na de Nederlandse verkiezingen van de zomer van 2010. De hervormers van Kunst van Leven opereerden nog enigszins in de lijn zoals ingezet in de jaren

\footnotetext{
${ }^{193}$ In 2002 werd Florida's boek The Rise of the Creative Class een wereldwijde bestseller. Hij schetst daarin het belang van een creatieve klasse (kunstenaars, ICT-professionals, modeontwerpers, homo's en lesbiennes, musici, dansers en 'hedendaagse bohemiens') voor stedelijke ontwikkeling en economie. Belangrijkste factoren daarbij zijn volgens hem technologie, talent en tolerantie (Florida, 2002, p. 249). In 2005 schetst hij in The Flight of the Creative Class dat aan de ene kant de creative class een hoge vlucht heeft genomen en wereldwijd groeit als belangrijke economische factor. Maar aan de andere kant constateerde hij dat er in die jaren een vlucht van creatieven uit de VS op gang kwam, vanwege een afnemende openheid en tolerantie ten aanzien van minderheden en buitenstaanders.
} 
zeventig, met een combinatie van sociaaldemocratische en neoliberale strategieën. Door de verkiezingswinst van de populistische PVV, die daarna sterk werd gepositioneerd in het gedoogkabinet-Rutte I, hadden zowel sociaaldemocraten als neoliberalen zich opeens te verhouden tot een radicale afwijzing van differentiering en vernetwerking van de samenleving. Waar de hervormingspogingen van Kunst van Leven nog uitgingen van een sturende rol van de overheid, wensten de nieuwe populistische hervormers alleen maar minder overheid en meer individuele vrijheid.

2012 - 2016. Meer dan kwaliteit: een nieuwe visie op cultuurbeleid (Ministerie van OCW, 2011). ${ }^{194}$ In juni 2010 werd het CDA, de partij van de zittende premier Jan-Peter Balkenende, nagenoeg volledig geëlimineerd. De PVV van Geert Wilders won vijftien zetels en kwam daarmee op 24 zetels in de Tweede Kamer. Staatssecretaris Halbe Zijlstra (VVD) kreeg cultuur in zijn portefeuille en was, in lijn met het kabinet-Rutte, groot voorstander van substantiële bezuinigingen op kunst en cultuur, als onderdeel van een grote bezuinigingsoperatie die 18 miljard euro moest gaan opleveren.

In zekere zin zou men kunnen zeggen dat door het electorale succes van de PVV het publiek dat door het gesubsidieerde theater niet of nauwelijks bereikt was, nu een invloedrijke stem kreeg. Waar het decennialang nauwelijks een rol speelde bij de inrichting en de waardering van het gesubsidieerde theater, anders dan door er om wat voor reden dan ook weg te blijven, liet het nu van zich horen. In de theatersector zowel als in aanpalende sectoren werd met verbijstering, woede en onbegrip gereageerd op de bezuinigingsplannen van 200 miljoen euro op een totaalbedrag van 900 miljoen euro aan kunstensubsidies. Vergeleken met andere sectoren (zorg, onderwijs, defensie) was het opmerkelijk dat het kabinet zo fors bezuinigde op de relatief kleine, kwetsbare sector van de kunst en cultuur. De publieke opinie, in een paar jaar tijd vertaald in stemgedrag en kabinetsplannen, werd gekleurd door een terminologie die uitdrukking gaf aan de gedachte dat in de kunst- en cultuursector lange tijd op een onverantwoorde manier gemeenschapsgelden bij elkaar gegraaid en opgesoupeerd werden; er werd veelvuldig met dédain gesproken over subsidies/urpers, over de overheid als een subsidie-infuus voor kunstenaars en over subsidieverslaving. Het taalgebruik in de media over de bezuinigingen op kunstsubsidies liet zien dat openlijke afwijzingen van kunst en cultuur waar te weinig publiek voor was, door een groot deel van de Nederlandse bevolking min of meer werden geaccepteerd. ${ }^{195}$ De oppositie en de cultuursector zelf spraken daarentegen van een desastreuze culturele kaalslag, disproportionele bezuinigingen en afbraak van de beschaving. Wat ooit

\footnotetext{
${ }^{194}$ In juni 2011 biedt staatssecretaris voor Cultuur in het kabinet-Rutte, Halbe Zijlstra, de kamerbrief Meer dan Kwaliteit: een nieuwe visie op cultuurbeleid aan het kabinet aan (Ministerie van OCW, 2011).

${ }^{195}$ Een eigen onderzoek door NRC Handelsblad in september 2011 liet zien dat 60 procent van de Nederlandse bevolking het eens was met de cultuurbezuinigingen door het kabinet-Rutte (Dool, 2011).
} 
verheven was en waartoe zelfs de gehele bevolking lange tijd verheven diende te worden door middel van een landelijk cultuurbeleid, werd door dit soort terminologie bijna gecriminaliseerd. Kunst en cultuur en mensen die in deze sectoren werkzaam waren, werden in de ogen van grote delen van de bevolking verdacht. Kunstenaars, cultuurbeleidsmakers en het Nederlandse publiek bedienden zich niet meer van hetzelfde vocabulaire in de discussie over de plaats van kunst in de samenleving en over de rol van de overheid in dat verband.

De keuzes die in eerste instantie gemaakt werden door de staatssecretaris lieten zien dat hij het advies van de Raad voor Cultuur om de 200 miljoen bezuinigingen gespreid in te voeren nagenoeg volledig naast zich neer legde (Ministerie van OCW, 2011, p. 2). De toenmalige voorzitter van de Raad voor Cultuur, Els Swaab, trok haar conclusies en stapte per 1 juli 2011 op. De Tweede Kamer nam vervolgens de plannen van Zijlstra eind juni 2011 over. De staatssecretaris koos voor het ondersteunen van een cultureel topsegment dat zich landelijk zowel als internationaal bewezen had. Het segment dat zo zou worden ontzien, werd wel de culturele eredivisie genoemd. Criteria voor rijksondersteuning waren: publieksbereik, ondernemerschap, participatie en educatie. Collecties dienen te behoren tot rijkscollecties van (inter)nationale betekenis en de focus lag op hoogwaardige kernpunten in het land (Amsterdam, Rotterdam, Den Haag, Utrecht, Groningen, Arnhem, Maastricht, Tilburg). Alle kunstensectoren werden geraakt door de plannen, maar de theatersector, met daarbinnen de experimentele kunst, de productiehuizen, de festivals en culturele instituten in de provincie in het bijzonder, leek de meeste subsidies te moeten gaan inleveren. Tevens werd gehandeld naar de stelling productie gaat voor ondersteuning, wat wilde zeggen dat er bezuinigd werd op sectorondersteunende instituten als het Theater Instituut Nederland. Wel werd er ingezet op ondersteuning van de creatieve industrie vanwege het groeiende belang ervan voor de economische ontwikkeling. ${ }^{196}$ In de kamerbrief van Zijlstra is in lijn met dit denken een accent op de economische betekenis van kunst en cultuur en een rol voor de markt te herkennen. In dit document van 42 pagina's komt 38 maal het begrip ondernemen voor in diverse combinaties (ondernemerschap, cultureel ondernemen). Voorts wordt het gekenmerkt door termen als economisch belang, internationale betrekkingen, omzet, vrije markt, marktpositie, creatieve industrie, economisch oogpunt, winstgevend; letterlijk is er te lezen: 'Uitgangspunt van het kabinet is om het economisch belang meer centraal te stellen. Het internationaal cultuurbeleid sluit hierbij aan' (Ministerie van OCW, 2011, p.5).

Veel reacties op de koersverandering van het cultuurbeleid van het kabinet-Rutte I gingen begrijpelijkerwijs over het hoeveel nog voor wie na 1 januari 2013. In meer

\footnotetext{
${ }^{196}$ De creatieve sector blijkt harder te groeien dan andere economische sectoren. In 2010 berekende onderzoeksbureau Berenschot dat de directe en indirecte opbrengsten van de creatieve industrie in breder economisch perspectief uitkwamen op zo'n 70 miljard euro per jaar (Vinkenburg, 2010).
} 
reflectieve artikelen zijn verschillende denkrichtingen te onderscheiden over het belang van kunst en cultuur, het waarom. In kringen van PVV-stemmers leek volgens verdedigers van traditionele cultuur (die door diezelfde PVV-stemmers 'elitair' werden genoemd) sprake van een rancuneuze ontlading jegens linkse bewoners van de grote stad in het algemeen en jegens de bewoners van de Amsterdamse grachtengordel in het bijzonder. Binnen de liberalen van de VVD vond een richtingenstrijd plaats tussen degenen die ervan uitgaan dat kunst als een democratische noodzaak het algemeen belang hoort te dienen en dus ruimhartig zou moeten worden gesteund door de overheid, en anderen die vinden dat kunst vooral een individueel belang dient. De eerste categorie liberalen had het moeilijk omdat binnen de coalitie rekening moest worden gehouden met de gedoogpartner, de PVV. Degenen die stonden voor eigen verantwoordelijkheid voor wat betreft cultuurbeleving, leken met de plannen het meest gediend.

De ontwerpen van Zijlstra wezen in de richting van een teruggang naar een rol voor de kunst als ornament, herkenbare kunst als veraangenamend en niet ontregelend, onderzoekend of bevragend. De keuze voor topkunst wees op het ondersteunen van traditionele instituten die zich in binnen- en buitenland ruimschoots bewezen hebben. De hele operatie werd in de gevestigde cultuursector beleefd als een hoofdzakelijk technocratische en bureaucratische ingreep zonder al te veel visie of substantiële onderbouwing. De oppositiepartijen verdedigden het veelgeprezen fijnmazige subsidiesysteem dat in de loop van de afgelopen zestig jaar was ontstaan, met de kanttekening dat daar uiteraard op gezette tijden kritisch naar gekeken zou moeten worden. Maar kritisch tegen het licht houden, scherp toetsen en daar dan vervolgens verantwoord naar handelen, is nog iets anders dan er met de botte bijl op inhakken, zoals de nieuwe plannen door menigeen werden gekenschetst. Er werd veelvuldig gewezen op het disproportionele percentage van de bezuinigingen op de kunsten in vergelijking met andere sectoren.

De Tweede Kamer nam in eerste instantie de bezuinigingsplannen over, behoudens bescheiden wijzigingen voor enkele regionale culturele instellingen. $\mathrm{Er}$ werd met verbijstering en woede gereageerd vanuit de sector. In de nacht van zondag 26 op maandag 27 juni, de dag van de stemming in de Tweede Kamer, vond de zogeheten Mars der Beschaving plaats. Op het Malieveld in Den Haag verzamelden zich enige duizenden hoofdzakelijk direct betrokkenen: beeldend kunstenaars, musici, filmers, kunstvakstudenten, theatermakers, dansers, acteurs en actrices. ${ }^{197}$ Het feit dat het protest hoofdzakelijk gevormd leek door direct of indirect betrokkenen, voedde de publieke opinie als zou het vooral gaan om het behoud van kunst- en cultuurbanen. Een veelgehoorde vraag was: waar was het publiek voor wie kunst en

\footnotetext{
${ }^{197}$ Op maandag 27 juni 2011 werden de plannen in de Tweede Kamer aangenomen. Schattingen van het
} aantal demonstranten dat deelnam aan de protestmars liepen uiteen van vijfduizend tot achtduizend. 
cultuur zo belangrijk zou zijn? Er werd op diverse plekken publiekelijk geconcludeerd dat de noodzakelijke structurele ideologische onderbouwing van overheidsondersteuning aan kunst en cultuur te lang verwaarloosd was geweest (Oosterbaan Martinius, 2011).

De cultuursector reorganiseerde zich na de invoering van de nieuwe structuur, met als meest opmerkelijke ontwikkeling de innovatieve flexibiliteit waarmee veel kunstenaars alsnog hun weg zochten met minder overheidssteun. In juni 2014 verscheen als opmaat voor het debat over de inrichting van het kunst- en cultuurbeleid voor de periode 2017 - 2020 een schets van trends en ontwikkelingen in het culturele leven in Nederland waartoe beleidsmakers zich zouden moeten gaan verhouden. De belangrijkste conclusies in De Cultuurverkenning. Ontwikkelingen en trends in het culturele leven in Nederland (Raad voor Cultuur, 2014, p. 41-42) waren:

- De gedrevenheid van kunstenaars in tijden van crisis en bezuinigingen is enorm, maar maskeert tegelijkertijd een grote verborgen werkeloosheid. Private financiering om beperkte publieke middelen te compenseren is achterwege gebleven.

- Verstedelijking zet door. De stad is de thuisbasis voor kunst en cultuur en de wereld het speelveld. Kunstenaars richten zich op de wereld vanuit de stad. Dit is nog nauwelijks te herkennen in een tot nu toe nog landelijk georganiseerd cultuurbeleid.

- Digitalisering is een structurele game changer en heeft enorme invloed op cultuurproductie en -consumptie; nieuwe verdienmodellen dienen zich aan. De overheid is terughoudend terwijl nieuwe vormen van financiering de aandacht vragen.

- De canonieke kunsten, waar nu de meeste overheidssteun naartoe gaat, verliezen terrein; het culturele leven differentieert sterk.

- Talentontwikkeling versplintert terwijl tegelijkertijd veel vernieuwingen verankering in een duurzame ontwikkeling missen.

Wat de uitkomsten van het debat dat hiermee ingezet wordt zullen zijn, is nog niet te zeggen. Opmerkelijk is wel dat er door het adviescollege van de overheid gepreludeerd wordt op een fundamentele reflectie op kunstenaarschap, op de positie van de canonieke kunsten en op de rol van de landelijke overheid.

In het theaterbeleidsdiscours van de periode $1970-2014$ hebben we een verscheidenheid aan vocabulaire de revue zien passeren en hebben we veranderingen daarin kunnen waarnemen. In de hiernavolgende analyse zal ik verhaallijnen trachten te destilleren op basis van specifiek taalgebruik zoals dat gangbaar was in bepaalde, van elkaar te onderscheiden periodes. 


\subsection{Het theaterbeleidsdiscours, een analyse in verhaallijnen}

Als we kijken naar verschuivingen die zich hebben voorgedaan met betrekking tot het hoe, het wie en het waarom van het theaterbeleid, zien we een complex discours. In verschillende tijdvakken worden verschillende antwoorden geformuleerd op deze vragen en wordt daardoor verschillend gesproken over wat we goed of slecht theater vinden en waarom. In elk van de periodes is bij het formuleren van beleid en van de legitimatie ervan gezocht naar een specifieke taal die de culturele orde van het moment het best uitdrukte en daarmee tegelijkertijd vormgaf. Belangrijk bij een discoursanalytische benadering van het theaterbeleidsdiscours is het besef dat schijnbare vanzelfsprekendheden niet voor de eeuwigheid vanzelfsprekend zijn. Ze worden in het discours voortdurend bevraagd en zelfs bevochten. Moet de overheid onderzoekstheater ondersteunen of theater faciliteren op basis van het grootst mogelijke publieksbereik, met de grootste gemene deler als richtsnoer? Dient gesubsidieerd theater het algemeen belang of is het slechts entertainment van een bepaalde bevolkingsgroep met een voorbeeldfunctie? Moet cultureel ondernemerschap in de theatersector ondersteund worden of is dat afhankelijk van de manier waarop dit begrip wordt uitgelegd? Dergelijke argumentatieve interacties zijn sleutelmomenten binnen een discursieve orde als die van het theaterbeleid. Tegenover het verhaal dat de overheid vertelt om haar beleidskeuzes te legitimeren, kiezen andere actoren in het discours positie.

De Nederlandse politicoloog en planoloog Maarten Hajer onderstreept in The Politics of Environmental Discourse: Ecological Modernization and the Policy Process (Hajer, 1995) het belang van verhaallijnen in een beleidsdiscours. Verhalen of storylines ${ }^{198}$ geven volgens Hajer richting aan het denken en scheppen orde in de complexiteit van een discours. Ze bepalen tegelijkertijd wat de inzet is van een conflict. Als verschillende actoren zich van eenzelfde verhaal bedienen reduceert dat potentieel problematische complexiteit. Discursieve macht wordt volgens Hajer manifest in de mate waarin actoren gedwongen zijn om zich te conformeren aan een bepaalde taal of onmachtig zijn om met eigen verhalen de gebreken van het geldende beleidsverhaal naar voren te halen. (Hajer, 2000, p. 19)

In het theaterbeleidsdiscours in Nederland konden de betrokken actoren (kunstenaars, beleidsmakers en publiek) elkaar gedurende kortere of langere perioden vinden in gedeelde verhaallijnen over bijvoorbeeld het experiment van het onderzoekstheater, over het onomstotelijke belang van gesubsidieerde repertoiretheater of over de noodzaak van diversiteit van het aanbod. Maar er waren ook botsende verhaallijnen, zoals die over de dwingende noodzaak van cultureel

\footnotetext{
${ }^{198}$ Hajer verwijst daarbij naar Bronwyn Davies en Rom Harré die het concept van storylines introduceerden (Hayer, 1995).
} 
ondernemerschap tegenover die van de verdediging van de autonomie van de kunsten. In deze paragraaf ga ik enkele van deze verhaallijnen belichten. Ik zal ze daarbij in verband trachten te brengen met cultuurcontextuele ontwikkelingen zoals die in deze studie centraal staan.

\section{Verhalen van goede en slechte kunst}

Vanaf de Tweede Wereldoorlog hebben zich grofweg zes achtereenvolgende verhaallijnen gevormd die richting hebben gegeven aan het theaterbeleidsdiscours, een zevende is in ontwikkeling.

De eerste verhaallijn was die van de verheffing van het volk. Vanaf 1945 werd op basis van ideologische beleidsuitgangspunten een theatersysteem van gezelschappen, podia en opleidingen opgezet, als onderdeel van een breder nationaal cultuurbeleid. Gezien hebbende hoe de Duitsers tijdens de bezetting categorieën hanteerden van 'goede (nationaalsocialistische) kunst' en 'slechte (entartete) kunst', droeg de Nederlandse overheid na de oorlog uit dat de samenleving het best gediend zou zijn met goede kunst in de zin van de schone kunsten voortkomend uit de canonieke westerse traditie. Wat daar niet onder viel, werd beschouwd als slechte kunst, geen kunst of in ieder geval minderwaardige kunst. Deze categorisering gold voor muziek, voor literatuur, voor veel beeldende kunst en ook voor het theater. De beleidsstrategie was om in woord en daad het Nederlandse volk cultureel te verheffen door het spreiden van de schone kunsten over alle lagen van de bevolking en in alle delen van het land. De overheid richtte zich hiermee sturend op de samenleving en het gesubsidieerde theater was daarbij een van de instrumenten (naast orkesten, dansgezelschappen, etc.). Dit denken in termen van verheffing van laagcultureel naar hoogcultureel hield stand tot ongeveer de helft van de jaren zestig, toen een andere interpretatie van de term verheffen gemeengoed werd.

Het nieuwe verheffen ging minder over laag- en hoogcultureel, maar meer over kritiek op de wederopbouw, over emancipatie, over sociale en internationale solidariteit en over andere culturele en politieke kleuren dan de door ingewijden als vanzelfsprekend veronderstelde. Jonge maatschappijkritische actoren binnen de theatersector resoneerden mee met bredere maatschappijkritische stromingen in een opstandige samenleving en voedden daarmee een ander verhaal dan dat van het belang van spreiding van canoniek toneelrepertoire. In deze veranderende culturele context botste het harmoniemodel van een nationale westerse monocultuur op een relatief nieuwe verhaallijn van het ruimte scheppen voor het verschil, voor kritiek, voor emancipatie en solidariteit. Vanuit de sector klonk een roep om ander repertoire, andere werkwijzen en een andere verhouding tot het publiek; beleidsmakers van de overheid werden hiermee stelselmatig geconfronteerd. Parameters voor wat in de 
driehoeksverhouding overheid, theatersector en samenleving beschouwd werd als goed theater veranderden daarmee in de richting van het nieuwe verhaal: traditioneel repertoiretoneel werd achterhaald bevonden en experiment en vernieuwing gingen de koers bepalen. Tegen deze achtergrond werden cultuurbeleidsuitgangspunten op scherp gezet en herijkt. Het eenduidige verheffingsverhaal werd in de loop van de jaren zeventig geleidelijk aan vervangen door een verhaal rond de noodzaak van kunsten cultuurvernieuwing, experiment en het leggen van een bredere relatie tussen kunst en samenleving op basis van toegankelijkheid en maatschappelijke relevantie (Ministerie van CRM, 1976a). Dat de overheid (Klompé) het Werkteater subsidie gaf voor het onderzoek naar nieuw repertoire en nieuwe werkwijzen was tekenend voor de normverschuiving.

De derde verhaallijn kreeg vorm in het begin van de jaren tachtig, toen het vernieuwingstheater in een bedenkelijk daglicht kwam te staan. De experimenteerdrift had met name in de peer group van de sector zelf zijn vruchten afgeworpen; het Nederlandse theater werd geroemd in binnen- en buitenland, ongebreidelde artistieke vrijheid leverde voor ingewijden goed theater op. De andere kant van de medaille was dat het grote publiek het steeds meer liet afweten en koos voor massacultuur en entertainment in plaats van voor de gesubsidieerde kunst. Het verhaal van experiment, vernieuwing en artistieke autonomie werd ook niet meer door alle cultuurbeleidmakers op dezelfde manier gedeeld. De in die periode van kleur veranderende politiek reageerde door te vragen naar het rendement van het cultuurbeleid. Dit denken in efficiëntietermen was deel van een grotere beweging in de politieke en bestuurlijke wereld en paste bij een over de gehele linie terugtredende overheid. Het leidde op dat moment nog niet tot concrete cultuurbezuinigingen, wel tot herijkingen; al een aantal decennia zwakte de Nederlandse overheid voorgenomen bezuinigingen voor de cultuursector af, niemand wilde blijkbaar zijn vingers branden aan een relatief kleine begrotingspost. In de in toenemende mate neoliberaal kleurende samenleving traden cultuurbeleidsmakers rond 1985 corrigerend op door de subsidiesystematiek voor kunst en cultuur te herzien. Het verhaal dat daarbij hoorde was dat van het belang voor cultuur en samenleving van concepten als kwaliteit en topkunst. Hiermee werd zowel de verhaallijn van de artistieke autonomie, zoals die vooropstond in de theatersector zelf, als de verhaallijn van maatschappelijke relevantie van het experiment, die voorheen het cultuurbeleid kleurde, opengebroken. Met het label topkunst werden kunst en cultuur in zekere zin weer ornamentaal, als vormen van verfraaiing van economische, politieke en maatschappelijke processen. De sector reageerde pragmatisch calculerend op deze herschikking. Experimentelen en vernieuwers van weleer zetten vanaf eind jaren tachtig hun werkzaamheden als een nieuwe generatie theaterleiders voort, maar dan met grotere budgetten, in de grote schouwburgzalen, aan het hoofd van gereorganiseerde grote gesubsidieerde 
theatergezelschappen. Regisseurs en artistiek leiders als Gerardjan Rijnders, Theu Boermans, Johan Simons, Ivo van Hove en Guy Cassiers konden zich met een hernieuwd elan vestigen als bespelers van de traditionele grote theaterzalen waartegen ze zich eerder afzetten. Deze beweging werd op meerdere manieren uitgelegd. Een uitleg is dat deze generatie het experiment vanaf dat moment verlegde van de kleine vlakkevloerzalen naar de grote schouwburgzalen en de internationale kunstenwereld, en dat ze daarmee baanbrekend is geweest; een andere lezing is dat deze generatie zich met deze verhuizing geconformeerd heeft aan de traditionele werking van grote schouwburgzalen en hun traditionele publiek.

In de loop van de jaren negentig drongen, gevoed vanuit explosief groeiende sociale en culturele domeinen buiten die van de gecanoniseerde westerse theatercultuur, concepten als hip hop, urban culture, digitale cultuur, e-cultuur, allochtonenkunst, gaming en internetkunst binnen in het kunst- en cultuurdiscours. Het grote publiek mocht zich dan van de officiële kunst hebben afgekeerd, het wendde zich in groten getale tot deze andere vormen van culturele beleving. Onder verantwoordelijkheid van staatssecretaris Van der Ploeg (PvdA) werd een cultuurbeleid uitgezet dat ruimte bood aan deze tot dan toe niet officieel erkende kunst- en cultuurvormen, opkomend vanuit domeinen van stadscultuur, jongerencultuur, digitale cultuur, massacultuur en migrantencultuur. Hij koppelde aan deze nieuwkomers en aan de bestaande gesubsidieerde kunsten een niet onomstreden verplichting tot een grotere eigen verantwoordelijkheid in de vorm van cultureel ondernemerschap. Daarmee zette hij naast het verhaal van de gevestigde en beschermde canonieke monocultuur een nieuw verhaal van een opkomende, ondernemende diversiteitscultuur (Ministerie van OCW, 1999b, p.11).

De vijfde verhaallijn verantwoordde de hervorming van de subsidiesystematiek die door staatssecretaris Van der Laan (D66) in 2003 werd ingezet en door haar collega Plasterk (PvdA) vanaf 2007 werd bestendigd. Voor de derde maal sinds eind jaren zestig werd zowel door beleidsmakers als door de theatersector zelf gezocht naar oplossingen om de opnieuw vastlopende verhoudingen tussen kunst, overheid en samenleving weer vlot te rekken. ${ }^{199}$ Van der Laan heropende in 2003 het gesprek over de cultuurnotasystematiek, die als beleidsinstrument volgens haar was 'verschrompeld tot verbureaucratiseerde en ontzielde procedure' (Ministerie van OCW, 2005, p. 1). De bestaande subsidieprocedure leidde tot versnippering in de sector en een moeizame relatie tussen officiële (goede) kunst en samenleving. De overheid wenste zich weer sterker sturend te richten op de relatie tussen kunst en samenleving en toonde zich in het hervormingstraject dat werd ingezet zowel gevoelig voor excellentie (topkunst), als voor cultuurparticipatie alsook voor een veranderende samenleving inclusief

\footnotetext{
${ }^{199}$ De eerste maal liep het systeem vast aan het eind van de jaren zestig, de tweede maal in het begin van de jaren tachtig.
} 
veranderende kunstpraktijken. Ze leek zich opnieuw inhoudelijk te willen verhouden tot een nieuwe tijd en beleidsuitgangspunten van zo'n dertig jaar cultuurbeleid te willen samenvatten: cultuurparticipatie droeg de verheffingsambitie van 1945 tot in de jaren zestig en zeventig in zich; oog hebben voor een veranderende samenleving doet sterk denken aan de periode vol vernieuwingsdrift van na Klompé en excellentie verwees naar het maatschappelijk geachte belang van topkunst en topkwaliteit vanaf de jaren tachtig. Dit vijfde verhaal was geen lang leven beschoren; de hervormingsgezinde beleidskoers strandde na de invoering per januari 2009 al vroegtijdig in de loop van 2010, toen de grote verkiezingsoverwinning van centrumrechtse partijen een aardverschuiving veroorzaakten in de Nederlandse politieke verhoudingen.

Belangrijk voor de nieuwe verhaallijn na de omslag in het cultuurbeleid door de kabinetten-Rutte I en II, die de kunstenwereld 200 miljoen euro bezuinigingen oplegden, was de stilzwijgende steun hiervoor van veel Nederlanders. Na decennialang méér geld voor kunst en cultuur te hebben uitgetrokken, verwees de overheid de kunstenwereld in feite voor een belangrijk deel naar de markt en grote delen van de bevolking gingen mee met dat verhaal. Staatssecretaris Zijlstra (VVD) stelde in lijn met het regeerakkoord het economisch belang centraal (Ministerie van OCW, 2011, p. 5): publiekscijfers en rendement werden richtinggevende concepten voor de zesde verhaallijn in het cultuurbeleidsdiscours. De gedifferentieerde aanbodgedachte als basis van cultuurbeleid brokkelde hiermee af; kunstenaars, kunstexperts en ook ingewijden bij de overheid werden als het ware ter verantwoording geroepen door een steeds mondiger publiek en zijn politieke vertegenwoordigers. Tegenover het 'niet van onze centen-adagium' van Henk en Ingrid ${ }^{200}$ hadden noch de sector, noch cultuurspecialisten in de Kamer een adequaat verhaal paraat om cultuursubsidies te verdedigen (Oosterbaan Martinius, 2011).

Het vervolg hierop, verhaallijn nummer zeven, is in ontwikkeling. Betrokken actoren reageren op de positie van de theatersector die zich sinds januari 2013 met minder overheidsmiddelen staande probeert te houden en op die van de overheid die zich probeert te verhouden tot een veranderende culturele sector. Er wordt zowel gesproken over een opmerkelijke flexibiliteit en overlevingsdrift in de theatersector, als over de noodzaak tot hersteloperaties na de ingrijpende bezuinigingsrondes. Een van de gebieden van waaruit zich een nieuwe verhaallijn lijkt te ontwikkelen, is het segment van de talentontwikkeling. Volgens sommigen is dit door de bezuinigingen op de productiehuizen veel te hard getroffen, volgens anderen is er in de huidige constellatie juist een creatieve herstructurering gaande. In de lopende

\footnotetext{
${ }^{200}$ Henk en Ingrid vormen een fictief echtpaar dat vaak wordt aangehaald in de communicatie over de Nederlandse politicus Geert Wilders en het partijprogramma van zijn partij, de PVV. Het staat voor een archetypisch en doorsnee Nederlands gezin dat de 'Hollandse waarden' hoog in het vaandel heeft.
} 
cultuurnotaperiode (2013-2016) is talentontwikkeling voor wat betreft het theater in hoofdzaak ondergebracht bij de grotere gezelschappen in de basis infrastructuur (BIS). De BIS-gezelschappen zijn wat hun positie en taakomschrijving betreft te omschrijven als residual, zich bezighoudend met klassiek en modern canoniek westers theaterrepertoire. Veel jonge aanstormende theaterprofessionals richten zich echter op ander repertoire, op andere dan de klassieke theaterpodia, of op een andere dan de gebruikelijke relatie tussen performers en hun publiek (emergent). In de omgang met hun podiumkunsten en met hun visie op de relatie tussen theaterkunst en samenleving, zijn ze vaak veel breder georiënteerd dan alleen op de gevestigde Nederlandse theatersector en richten ze zich op performatieve werelden buiten de BIS, waar zaken als community art en social design, onderzoekstheater, intermedialiteit, film en televisie, performances en media tout court veel meer dominant zijn dan het canonieke repertoire en de bijbehorende productiewijze waarbinnen ze zich als talent op basis van de afspraken in de huidige constellatie dienen te ontwikkelen. Met andere woorden, het verhaal van de goede kunst zoals de overheid dat vertelt, herkennen velen van de aanstormende talenten niet als hun verhaal; zij kennen een ander, breder verhaal.

\section{De driehoek overheid - kunst - samenleving}

Als we naar de opeenvolgende verhaallijnen kijken die het Nederlandse theaterbeleid legitimeren, zien we dat die in bepaalde periodes gaan over veranderende verhoudingen tussen kunst en samenleving in relatie tot de culturele context. Klompé gaf met het verhaal van de maatschappelijke relevantie ruimte aan noodzakelijk geacht onderzoek naar nieuw theaterrepertoire en nieuwe werkwijzen; ze zocht daarmee binding met wat er op dat moment contextueel in de samenleving gebeurde (emancipatie, experiment). Dat geldt later evenzeer voor de beleidsperiode van Van der Ploeg, waarin de overheid het subsidiëren van relatief nieuwe cultuuruitingen (urban, digitaal, intercultureel) verantwoordde met het verhaal van de diversiteitscultuur. Op andere momenten gaan de verhaallijnen juist weer niet over het zoeken van aansluiting met contextuele culturele reuring, maar over het ondersteunen van zich bewezen hebbende canonieke dan wel experimentele kunsten, met het oog op het bestendigen van neoliberaal gekleurd denken in termen van rendement, publiekscijfers en economische efficiëntie. In Williams' terminologie kunnen we voor wat betreft het bevragende onderzoekstheater spreken van een emergente categorie en voor wat betreft het repertoiretheater van een residuale. Afhankelijk van de politieke wind en de tijdgeest is in de afgelopen veertig jaar dan weer het een dominant geweest (onderzoekstheater onder Klompé en diversiteit onder Van der Ploeg), dan weer het ander (repertoiretheater onder Zijlstra). Klompé 
en Van der Ploeg stonden in verschillende tijdvakken als het ware bepaalde elementen toe om, in termen van Even-Zohar, een beweging te maken vanuit de periferie van het culturele leven naar het centrum van de gesubsidieerde podiumkunsten; het Werkteater werd van een aanvankelijk marginaal clubje een decennialang toonaangevend gezelschap met in zijn kielzog een veelvoud aan zich op een vergelijkbare manier ontwikkelende gezelschappen en collectieven. Het recente gebruik van economische terminologie in relatie tot de gevestigde cultuur kan ook gezien worden als het toestaan van een nieuw element, het element van het marktdenken, vanuit de periferie naar het centrum, maar dan ontstaan vanuit een ander wereldbeeld.

In de heen-en-weerbewegingen van de overheid manifesteert zich de paradox van het beleidsdiscours: de overheid intervenieert door subsidiering in de relatie theaterkunst en samenleving, maar het publiek keert zich tegelijkertijd grotendeels af van theaterkunst die door overheidssteun wordt aangestuurd. In beide hierboven genoemde periodes waarin de overheid beleidsmatig aansluiting zocht met wat er in de samenleving speelde, bloeide weliswaar de theatersector bovengemiddeld op, maar een groot deel van het publiek reageerde op zijn minst terughoudend of zelfs afkerig op deze overheidsvoorkeuren. In juni 2010 stond een nieuwe cultuurbeleidsperiode net in de steigers, Kunst van Leven en de subsidienota die daarbij hoorde waren per 1 januari 2009 ingegaan en een tussentijdse meting van de bevindingen in de sector liet zelfs een milde tevredenheid zien (Horst \& Zoutman, 2010). De overweldigende overwinning van de populistische PVV bij de verkiezingen strafte in zekere zin de culturele zelfgenoegzaamheid en vanzelfsprekendheid van de verhalen van de gevestigde theatertraditie, canoniek dan wel experimenteel, af. Actoren in beleidsgremia en in de theatersector zelf kregen de rekening gepresenteerd voor het feit dat er in het discours te weinig binding was geweest met de culturele en maatschappelijke context; je zou kunnen zeggen dat wat er in die context gebeurde, te weinig serieus genomen was. Dit gebrek aan binding tussen de peer group van de cultureel ingewijden binnen het theatersysteem en de maatschappelijke context was in de jaren daarvoor al enkele keren gesignaleerd door cultuurexperts en publicisten.

Cultuurcriticus Paul Kuypers stelde in 2005 al dat de discussie rond subsidiëring en de legitimering ervan te weinig binding heeft met de maatschappelijke context. Het theaterdiscours ontbeert volgens hem de connectie met veel bredere waardeschalen dan alleen die van het puur artistieke of theatrale. Hij schrijft:

'Het toneel is daardoor niet in staat de grenzen van het "voorstellende" te overschrijden. Het blijft gevangen in de taal en de codes van de bestaande systemen en het blokkeert daarmee voor zichzelf de toegang tot een ander discours en tot dat wat men de "materialiteit van de werkelijkheid" zou kunnen 
noemen." (...) Er ontstaat ondercomplexiteit door een tekort aan verwerkingscapaciteit. Het [theater. $\mathrm{HH}$ ] systeem is te veel naar binnen gekeerd. Het refereert vooral aan eigen thema's en behoeften en is te weinig responsief ten opzichte van stromen en bewegingen in de buitenwereld' (Kuypers, 2005).

Kuypers beschuldigde de toenmalige toneelsector van conceptuele armoede. Een vergelijkbare kritiek op het gevestigde deel van de sector kunnen we lezen in De grens als spiegel. Een vergelijking van het cultuurbestel in Nederland en Vlaanderen van Quirine van der Hoeven uit dezelfde periode. ${ }^{201}$ In haar vergelijking van het Nederlandse cultuurbestel met dat van Vlaanderen beschrijft ze die afstand tussen de gevestigde cultuurwereld en de maatschappelijk context in de Nederlandse situatie als volgt:

'Het Nederlandse gesubsidieerde culturele bestel doet denken aan een spiegel, niet de spiegel van de maatschappij die de Raad voor Cultuur voor ogen heeft, maar eerder een spiegelpaleis. In dit paleis huist het gesubsidieerde cultuurwereldje van adviseurs, culturele instellingen, ambtenaren en politici. Zij zien zichzelf en elkaar in het paleis tot in het oneindige gereflecteerd, waardoor het lijkt alsof er niets is buiten dat paleis, wat uiteraard niet het geval is. In de wereld buiten de paleismuren doen zich belangrijke ontwikkelingen voor, die uiteindelijk ook hun weerslag zullen hebben op het leven in het paleis' (Hoeven, 2005, p. 145).

De noties van Kuijpers en Van der Hoeven komen in de buurt van wat Warna Oosterbaan Martinius in juli 2011 de ideologische armoede van de sector noemde:

'De staatssecretaris schreef maandag geschiedenis. Niet alleen door het ongekend hoge bedrag dat hij van de kunstbegroting afhaalde. Van nog groter betekenis is dat zijn optreden duidelijk maakte hoe wankel het ideologische fundament onder de kunstsubsidie is. Ook de oppositie bleek niet meer te weten waarom de staat kunst zou moeten steunen. (...) Een overtuigend weerwoord ontbreekt en het gekerm dat opstijgt uit de oppositiebanken verraadt vooral één ding: ideologische armoede' (Oosterbaan Martinius, 2011).

\footnotetext{
${ }^{201}$ Van der Hoeven promoveerde in februari 2012 aan de Universiteit Utrecht op het proefschrift Van Anciaux tot Zijlstra. Cultuurbeleid en cultuurparticipatie in Nederland en Vlaanderen (Hoeven, 2012). Als basis voor haar onderzoek diende haar publicatie uit 2005, De Grens als spiegel. Een vergelijking van het cultuurbestel in Nederland en Vlaanderen (Hoeven, 2005). Deze publicatie zowel als haar proefschrift werden uitgegeven door het Sociaal Cultureel Planbureau (SCP) waar de auteur tijdelijk werkzaam was.
} 
Oosterbaan schrijft voorts dat populaire cultuur wat hij noemt een statusstijging aan het doormaken is, maar dat hiervan weinig terug te zien is in het subsidiestelsel, wat overigens volgens hem voor de hand ligt omdat de meeste segmenten van populaire cultuur zichzelf kunnen bedruipen. Toch tast die statusstijging onvermijdelijk ook de exclusiviteit van de hoge kunsten aan en daarmee de legitimiteit van hun subsidiëring (Oosterbaan, 2011). Thije Adams sprak eerder in dit verband van een vorm van 'ontkerkelijking' van de kunst; het grote publiek kiest voor andere cultuursegmenten dan de door de overheid beschermde canonieke kunst of voor nieuwe vormen van cultuurbeleving of van self design (zelf doen). Het publiek laat zich hoe dan ook steeds minder kunst als goede kunst voorschrijven door overheid en ingewijden, terwijl de overheidsfinanciering zich onverminderd blijft richten op deze officiële 'culturele kerk' (Adams, 2010).

Anno 2015 blijkt er inmiddels in de theatersector en in aanpalende kunst- en cultuurdomeinen wel oog voor de noodzaak van meer externe relaties in de richting van de maatschappelijke context en voor een zekere connectiviteit met andere dan gevestigde cultuursectoren, maar dat is nog iets anders dan van overheidswege structureel en radicaal innovatief mede vormgeven van een dergelijke betrokkenheid van de cultuursector bij een 'wereld buiten de paleismuren' (Hoeven, 2005, p. 145), bij de cultureel dynamische context buiten de gevestigde sectorgrenzen.

Het wordt interessant om te bezien welke ideologische positie de Nederlandse overheid de komende jaren in gaat nemen in het kunstendiscours in het algemeen en in de relatie tussen theater en het bredere performatieve in het bijzonder. Kiest zij voor voortzetting van de ondersteuning van traditionele, gekende, canonieke, herkenbare en economisch te verantwoorden cultuur inclusief het theater, zoals onder leiding van Zijlstra ingezet door het kabinet-Rutte II of ontwikkelen zich in de artistieke praktijk, in de samenleving en in het politiek bestuurlijke circuit nieuwe verhaallijnen die de komende jaren richtinggevend gaan worden? De terminologie in de recente publicatie De Cultuurverkenning (Raad voor Cultuur, 2014) van de Raad voor Cultuur toont in ieder geval dat het besef groeit dat er meer aan de hand is rond culturele beleving dan alleen een politieke stammenstrijd tussen populistische, liberale en sociaaldemocratische uitleg van wat overheidsbeleid ten aanzien van kunst- en cultuuruitingen zou moeten zijn. De kaders van het strijdperk lijken mede te worden gevormd door grenzen en verbindingen tussen de stad en de wereld, tussen de digitale en de analoge wereld, tussen het gevestigde traditionele en het opkomend hybride kunstenaarschap. Deze beweging zou uitgelegd kunnen worden als een herpositionering van zowel de overheid als van theater, performance en media ten opzichte van elkaar en ten opzichte van de samenleving, een verschuiving van ideologisch gekleurde posities in het discours, van hiërarchisch (canoniek) en lineair 
(ketengedacht) gekaderde posities naar posities binnen een vlakker en meer modulair geordend spectrum.

\subsection{Conclusies}

In dit hoofdstuk zijn in grote lijnen de discursieve bewegingen van het Nederlandse theaterbeleid en het specifieke taalgebruik dat daarbij hoorde voorbij gekomen, van 1945 tot in 2015 . Als we kijken naar verschuivingen die zich hebben voorgedaan met betrekking tot het hoe (subsidies, cijfers, procedures), het wie (soorten gezelschappen, podia, publiek) en het waarom (verheffen, sociaal-maatschappelijke reflectie, ornamentrol, culturele diversiteit, rendement) van het theaterbeleid, afgezet tegen verschillende tijdvakken, zien we een complex beweeglijk discours. De drie vraagstellingen hebben betrekking op de complexe driehoeksverhouding tussen het theater, de samenleving of het publiek, en de Nederlandse overheid in de vorm van een theaterbeleid met bijbehorend subsidies. In verschillende tijdvakken worden verschillende antwoorden gegeven op deze vragen en wordt daardoor verschillend gesproken over wat we goed of slecht theater vinden.

In de periode 1945-2015 werd in het theaterbeleidsdiscours in een aantal periodes gesproken over crises waarin het Nederlandse theater zich bevond en werd er door overheid, Raad van Cultuur, theatersector en theoretici gezocht naar oplossingen om die crises het hoofd te bieden. Tot aan de jaren zeventig veranderde er relatief weinig aan de koers van het cultuurbeleid van de overheid, ingezet na 1945: de schone kunsten dienden te worden gespreid over de totale bevolking en er bestond geen twijfel over wat goede kunst was en wat niet. Dat begon te veranderen vanaf de tweede helft van de jaren zestig. In de jaren zeventig en eind jaren negentig sprak men onder invloed van centrumlinkse kabinetten interdiscursief vol vuur over maatschappelijke relevantie, experiment en diversiteitscultuur, terwijl dat niet op een evenredig succesvolle manier terug te zien was in de publieke beleving. Begin jaren tachtig en vanaf 2010 vond er onder invloed van centrumrechtse kabinetten een herschikking naar meer traditionele waarden plaats en een sanerende bezuinigingsoperatie, en werd het discours gedomineerd door verhalen over topkunst, cultureel ondernemerschap en publieksbereik terwijl een groot deel van de peer group kritisch stond tegenover dit denken in markttermen. Anno 2015 heeft gevestigde mainstream podiumkunst zich geconsolideerd, redden delen van het experimentele en kritische theatersegment zich na de bezuinigingsrondes nog enigszins door creatieve financieringsmodellen onder nieuwe omstandigheden en verbreedt het performatieve spectrum zich opmerkelijk vaak buiten de officiële kunstcircuits.

Lehmann spreekt in 1999 in zijn Postdramatisches Theater over een nieuwe theateresthetiek zoals die vorm kreeg in een internationale context en over het 
postdramatische in Duitsland als over een theateravant-garde naast de mainstream van de grote Duitse stadtheaters. Hij betrekt in zijn analyse niet expliciet het Duitse cultuur- of theaterbeleid. In Nederland en Vlaanderen is de situatie vanaf het begin van de jaren zeventig anders geweest dan die in Duitsland. Het Nederlandse subsidiebeleid van de jaren zeventig, tachtig en negentig leverde een door vakgenoten en ingewijden veelgeprezen artistieke vrijheid voor het theater op. Het verhaal van het experiment, het postdramatische, is vanaf de jaren zeventig door de Nederlandse overheid gedeeld, waardoor zij een innovatief medeconstituerende actor werd. Veel van de gevestigde gezelschappen in het gesubsidieerde theatersysteem belichaamden in feite met hun artistieke werking in meer of mindere mate de door Lehmann beschreven postdramatische theateresthetiek. Het sanctioneren van deze innovatieve artistieke praktijk door middel van beleid veranderde niet toen de verhaallijn begin jaren tachtig verschoof naar een meer neoliberaal perspectief; er werd alleen formeel afstand genomen van een al te grote nadruk op experiment en vernieuwing. Het cultuurbeleid van de overheid werd voortaan aangestuurd vanuit de concepten topkwaliteit en kwaliteitskunst maar bleef aanbodgestuurd en veranderde alleen inhoudelijk nog een keer van kleur toen Van der Ploeg rond de millenniumwissel inzette op een groter aandeel voor urban culture, digitale media, jongeren en nietwesterse cultuuruitingen. Met de ideologische omslag in Nederland na de verkiezingen van 2010 veranderde er iets wezenlijks. Er werd door het nieuwe kabinet voor het eerst sinds 1945 rigoureus gekapt in het kunstenbudget, met name in de budgetten voor experiment, talentontwikkeling en artistiek onderzoek. Het accent in het theatersysteem kwam nagenoeg volledig te liggen bij gevestigde gezelschappen, bij het stimuleren van marktwerking en cultureel ondernemerschap; een expliciete relatie met een onverminderd veranderende culturele context was verder te zoeken dan ooit. Markt, marketing en publiekscijfers zijn daarmee gewone parameters geworden voor gevestigde canonieke spelers in het Nederlandse theatersysteem. Het gewicht van beleidsdoelen en uitgangspunten van overheidssteun is in enkele decennia verschoven van de artistieke prioriteiten van innovatieve kunstenaars, via een accent op gevestigde topkunst, naar een grote nadruk op marktwerking, rendement, publiekscijfers en efficiëntie.

Als we kijken naar de driehoek overheid-kunst-samenleving, met de uitspraken van Kuypers, Van der Hoeven, Oosterbaan Martinius en Adams bij de hand, zouden we kunnen zeggen dat in het theaterbeleidsdiscours de overheid vooral met gevestigde partners uit de sector in gesprek is en dat het discours binding met de culturele en maatschappelijke context ontbeert. We kunnen zeggen dat het overheidsbeleid in zijn totaliteit residual is. De overheidsgesubsidieerde theatergezelschappen anno 2015 behoren tegen de achtergrond van een veel breder geformuleerd performatieve spectrum tot een traditioneel gekaderde achterhoede. We zien dat de overheid stuurt 
in de relatie tussen kunst en samenleving maar dat het publiek zich juist vaak afkeert van de officiële 'culturele kerk', van het gesubsidieerde canonieke dan wel experimentele theateraanbod. De samenleving definieert 'het theater' en 'het performatieve' breder en verhoudt zich anders dan de overheid tot de totaliteit van het performatieve spectrum. De vraag die boven de markt hangt is hoe de overheid omgaat met de verhouding die zich in dit tijdvak vormt tussen aan de ene kant story driven games, immersive media, community art-projecten en de vlucht voorwaarts die de betere dramaseries aan het maken zijn, en aan de andere kant de huidige dominante gesubsidieerde theater- en muziekpraktijken. De statusstijging die populaire cultuur doormaakt, heeft zich nog niet vertaald in het beleidsdiscours. Daarmee zouden we kunnen zeggen dat ondanks transformaties in het beleidsdiscours, de overheid nog geen antwoord heeft op het verhaal van het publiek. Het zwaar aangezette accent op marktwerking en op veronderstelde onmiddellijke verkoopbaarheid van uitgekristalliseerde topkunst in de lopende cultuurnotaperiode (2013-2016) heeft tot gevolg dat er weinig oog is voor de culturele en maatschappelijke betekenis van buitenterritoriale verschijnselen van kunst en cultuur en daarmee voor het potentiële sociale, culturele en maatschappelijke gewicht van wezenlijk veranderende theater-, performance- en mediapraktijken en hun samenhang in nieuwe kunst- en culturele kaders. In de notitie De Cultuurverkenning (Raad voor Cultuur, 2014) kijkt de Raad voor Cultuur echter al nadrukkelijk vooruit door te wijzen op de noodzaak om deze buitenterritoriale verschijnselen serieus te gaan nemen, als onder meer gesteld wordt dat digitalisering een structurele game changer is, dat de canonieke kunsten terrein verliezen en dat vernieuwingen duurzame ontwikkeling missen. 


\section{Hoofdstuk 7 Conclusies}

'Kunst helpt ons om de wereld beter te begrijpen' (Ruth Mackenzie) ${ }^{202}$

Theater: crisis of herpositionering?

Dit onderzoek startte vanuit mijn fascinatie voor de beweeglijkheid van het theater-, performance- en mediadiscours. Ik vroeg me af of het Nederlandse theater de afgelopen decennia nu werkelijk de ene crisis na de andere beleefde of dat er vanuit een ander perspectief gesproken kan worden van een herpositionering van het gevestigde theater. Hoe verhoudt zich de reeks vermeende crises van het gevestigde theater tot de waarneembare intermediale, interculturele en internationale culturele dynamiek, waarbinnen zich in de loop der tijd een performatief spectrum heeft gevormd? Om een antwoord op deze vraag te formuleren heb ik de afgelopen jaren de werking van vier institutionele actoren in het theatersysteem nader bestudeerd en heb ik me afgevraagd of er steekhoudende uitspraken te doen zijn over de verhouding tussen bestaande theaterinstituties en een expanderende culturele context.

Practice based research

Deze studie naar transformaties van theaterinstituties is een bijdrage vanuit de praktijk aan het discours dat ontstond rond het postdramatische theater na de publicatie van Lehmanns studie in 1999 (Lehmann, 1999). Na de onderkenning van het postdramatische als innovatieve theateresthetiek en na de doorontwikkeling van het discours in een overlap met gelieerde domeinen van performance- en mediastudies, heb ik de gevolgen daarvan op theaterinstitutioneel niveau willen traceren. Ik heb Lehmanns vocabulaire als vertrekpunt genomen en onderzocht wat er concreet aan transformaties zichtbaar is geworden in de theaterpraktijk van gezelschappen, podia, opleidingen en beleidsgremia.

\footnotetext{
${ }^{202}$ Ruth Mackenzie is sinds 2014 directeur van het Holland Festival. Dit citaat was een uitspraak van haar in een interview voor NRC Handelsblad (Spel \& Wensink, 2015) en werd gebruikt als de kop boven het artikel over de door haar geambieerde koers met het festival.
} 
Bij mijn 'dialoog' met Lehmann dient in acht genomen te worden dat ik met mijn onderzoek niet in de eerste plaats een academisch debat met Lehmann en andere theaterwetenschappers heb willen voeren. De context van mijn onderzoek wordt gevormd door de dagelijkse praktijk van een Nederlandse theateropleiding en haar operationele verbindingslijnen met de actuele praktijk van gezelschappen, podia, opleidingen en beleidsgremia. Om die reden kan mijn onderzoek opgevat worden als practice as research. Dat heeft qualitate qua geleid tot een ander type conclusies dan die welke een puur academische studie mogelijkerwijs opgeleverd zou hebben. Mijn conclusies zijn op te vatten als aanbevelingen om de inrichting, de beoogde werking en de structuur van de Nederlandse theater-, performance- en mediapraktijk te heroverwegen.

In de hierna volgende paragrafen zal ik eerst de opbrengsten van de casestudies beschrijven, vervolgens ingaan op die uitkomsten in dialoog met Lehmann en andere actoren in het discours dat volgde op zijn werk. Dan formuleer ik concluderende aanbevelingen voor de praktijk van de theaterinstituties, om af te ronden met een beschouwing over de rol van kunst in de samenleving gekoppeld aan de werking en de betekenis van theater en het performatieve spectrum in een netwerksamenleving.

\section{De opbrengst van de casestudies}

Als we kijken naar de opbrengsten van de casestudies, dan kunnen we de volgende inzichten formuleren over de hedendaagse praktijk van een gezelschap, een podium, een theateropleiding en een theaterbeleid.

Bij Toneelhuis Antwerpen zien we dat de contouren, de constructie en de werking ervan niet meer helemaal overeenkomen met wat we traditioneel verstaan onder een grootschalig gesubsidieerd theatergezelschap. Het gespeelde repertoire is gedifferentieerder dan alleen werk dat gebaseerd is op het canoniek literair dramatische en dat levert een andere theateresthetiek op. Ten gevolge daarvan veranderen de samenstelling, organisatie en werkwijze van het gezelschap. Een belangrijke transformatie is dat technologie in veel voorstellingen van het gezelschap thematisch, vormgevingstechnisch en dramaturgisch van grote invloed is; de technologie is niet meer alleen dienstbaar maar in veel gevallen artistiek medeconstituerend. Dit heeft onder meer bijgedragen aan de artistieke emancipatie van de theatertechnicus. Naast deze invloed van technologie is het ontslaan van het aanvankelijke spelersensemble in $\mathbf{2 0 0 6}$ en het aanstellen van een divers samengestelde en wisselende kunstenaarsstaf van individuele kunstenaars en collectieven, een radicale transformatie geweest die het toenemende gewicht van onthiërarchiserende intermediale, interculturele en internationaliserende ontwikkelingen tekent. 
De Verkadefabriek is in relatief korte tijd een rol van betekenis gaan spelen als intercultureel podium voor de stad's-Hertogenbosch en verre omgeving. Het gebouw en de organisatie 'performen' als het ware het samengaan van en onderling schakelen tussen uiteenlopende culturen. Deze performativiteit van het gebouw belichaamt een streven naar interculturele ontmoetingen. De groeiende diversiteit van dit soort podia problematiseert de werking van gevestigde theaterpodia. Traditionele stadsschouwburgen en aanverwante podia zijn met hun gesubsidieerde programmering niet meer de centrumpodia van het culturele leven, terwijl ze daar voor een groot deel nog wel hun status aan ontlenen. Hun positie is daarmee, anders dan die van emergente hybride podia als de Verkadefabriek, hoofdzakelijk residueel geworden. Het is voor traditionele theaterpodia ingewikkelder om nieuwe publiekstrategieën te ontwikkelen in een substantieel veranderde culturele constellatie dan voor relatief nieuwe fysieke dan wel virtuele podiumvarianten. Podia als de Verkadefabriek zijn meer ingesteld op modulair schakelen tussen interculturele, intermediale en internationale cultuuruitingen en interessegroepen. De transformatie van theaterpodia naar deze hybride centra waar diverse soorten publiek de mogelijkheid hebben om te schakelen tussen verschillende soorten van cultuurbeleving, draagt bij aan de toenemende differentiatie van het performatieve spectrum.

Het veranderen van het theaterlandschap in een spectraal samenhangend theater-, performance- en medialandschap heeft vergaande consequenties voor een theateropleiding als de Toneelacademie Maastricht. Niet alleen het opleiden van theaterprofessionals verandert, maar ook de positionering van de opleiding in het theaterlandschap. Was de opleiding voorheen vooral faciliterend voor de gevestigde theaterpraktijk, nu is ze - mede door vervagende grenzen tussen de beroepsprofielen van acteurs, regisseurs, mediakunstenaars en performers, en door een toenemende gerichtheid op practice based onderzoek en zelfreflectie - medeconstituerend geworden voor de actuele performatieve praktijk. De relatie van de Toneelacademie met de beroepspraktijk toont een verschuiving van een gerichtheid op het Nederlandse gesubsidieerde theater naar de internationale hybride theater-, performance- en mediapraktijk. Tevens voltrekt zich aan de Toneelacademie een interculturele transitie, van 'hagelwit' naar een gekleurde en internationale gemeenschap van studenten met zeer diverse achtergronden. Interculturele ontwikkelingen manifesteren zich op de opleiding niet alleen tussen westers en nietwesters georiënteerden, ook interacties tussen 'hoge' en 'lage' cultuur, tussen analoge en digitale cultuurbeleving, tussen canoniek toneelrepertoire en televisie en film zijn manifest geworden. Voorheen eenduidig theatraal vakmanschap is zich op de Toneelacademie aan het uitkristalliseren tot een breed palet van performatief vakmanschap. 
De casestudie naar het Nederlandse theaterbeleid laat zien dat het theaterbeleid van de overheid wordt gekenmerkt door een sterke afhankelijkheid van de politieke situatie van het moment. Het belang van het experiment, het postdramatische, werd vanaf de jaren zeventig door de Nederlandse overheid gedeeld, waardoor zij in die periode een innovatief medeconstituerende actor werd. Door het meer neoliberaal perspectief vanaf het begin jaren tachtig vond er een herschikking naar meer traditionele waarden plaats. Met de ideologische omslag in Nederland na de verkiezingen van 2010 veranderde er iets wezenlijks. Voor het eerst sinds 1945 werd het kunstenbudget gekort, met name het budget voor experiment, talentontwikkeling en artistiek onderzoek. Het accent van het overheidsbeleid kwam te liggen bij gevestigde gezelschappen, marktwerking en cultureel ondernemerschap. In het theaterbeleidsdiscours is de overheid mede daardoor vooral met gevestigde partners uit de sector in gesprek en mist het binding met de dynamische culturele en maatschappelijke context. We kunnen zeggen dat het overheidsbeleid daarmee in zijn totaliteit residual is. De samenleving definieert 'het theater' en 'het performatieve' breder en verhoudt zich anders dan de overheid tot de totaliteit van het performatieve spectrum. De statusstijging die populaire cultuur doormaakt, heeft zich nog niet vertaald in herschikkingen van posities en werkwijzen van de belangrijkste actoren in het theaterbeleidsdiscours. Het zwaar aangezette accent op marktwerking en op veronderstelde onmiddellijke verkoopbaarheid van uitgekristalliseerde topkunst in de lopende cultuurnotaperiode (2013-2016) heeft tot gevolg dat er weinig oog is voor de culturele en maatschappelijke betekenis van buitenterritoriale verschijnselen van kunst en cultuur en daarmee voor het potentiële sociale, culturele en maatschappelijke gewicht van veranderende performatieve praktijken en hun samenhang in nieuwe kunst- en culturele kaders.

\section{Voorbij Lehmanns theateresthetiek}

Lehmann schetste in Postdramatisches Theater (Lehmann, 1999) een differentiatie van het westerse theaterrepertoire, een onthiërarchisering van theatrale middelen en een toename van intermediale productiewijzen. Volgens Lehmann loopt er een doorgaande lijn van theateresthetische ontwikkelingen vanaf de historische avantgarde van begin twintigste eeuw, via het werk van Brecht en de postdramatische vernieuwers vanaf 1970 tot aan eind twintigste-eeuwse theatergezelschappen. Met name in de periode vanaf 1970 kristalliseerde zich volgens hem een nieuwe theateresthetiek uit die vooruitwees naar een theater van de toekomst. We zijn nu, vijftien jaar later, in Lehmanns toekomst van toen. Wat kunnen we opmerken als we tegen deze achtergrond de opbrengsten van de casestudies nader beschouwen? 
We kunnen in ieder geval zeggen dat het intermediale een vlucht heeft genomen die groter is dan verwacht, gepaard gaand met interculturele en internationale ontwikkelingen in een meer en meer interdisciplinair wordende podiumkunstenpraktijk. Het is een logisch gevolg van de digitale communicatie waarmee ons huidige culturele en maatschappelijke leven volledig doordesemd is: alles is met alles te verbinden in de netwerksamenleving. Lehmanns noties voor het theater en het vervolg erop in het discours rond de dichotomieën woord - beeld, theater - performance, theater - media en betekenis - ervaring, kunnen doorgetrokken worden tot in elkaar overlappende grensgebieden (Peters, 2009) tussen theater en andere kunstendisciplines (beeldende kunst, immersieve media, film, televisiedrama, dans, muziek, literatuur), evenals tot in aangrenzende cultuur- (festivals, massacultuur, mode, design) en kennisdomeinen (media- en performancestudies, geesteswetenschappen). Voor theaterproducenten is het een vanzelfsprekendheid geworden om digitale media in te zetten, om samen te werken met beeldende kunstenaars of dansers en om theatervoorstellingen niet meer louter te baseren op canonieke toneelteksten; op theateropleidingen opgeleide acteurs, regisseurs, performers en scenografen werken net zo vaak zo niet vaker na hun opleiding bij de film, in een zelf opgezette kunstpraktijk of voor televisiedrama; het begrip podium kent vele varianten inclusief digitale. Alleen is het podiumkunstenbeleid afhankelijk van de politieke actualiteit van het moment, wat wil zeggen dat er in de ene periode meer oog is voor bovenstaand grensverkeer en in andere periodes minder.

Het onderzoek heeft het inzicht opgeleverd dat de wereldwijde opkomst van de digitale netwerksamenleving en de vaktechnische en thematische gevolgen daarvan voor de praktijk van het theater nog niet in hun volle omvang werden voorzien door Lehmann ${ }^{203}$. Veel van de toentertijd waargenomen transformaties werden door hem voornamelijk gezien als theaterextensies, als veranderingen binnen een nog steeds als theater gekaderd kunstdomein. Lehmanns betoog was hoofdzakelijk gericht op de doorontwikkeling van drama als referentiepunt, op dramatische categorieën en mutaties daarvan binnen het theater als kunstdiscipline. Het theater bleef daarmee voor hem nog voor een groot deel als representerend medium tegenover of naast het momentane presenterende van veel eigentijdse cultuuruitingen staan. Technologische ontwikkelingen hebben echter op grote schaal van woord beeld, van beelden soundscapes, van poëzie film en van betekenis ervaring gemaakt (Fischer-Lichte, 2004, 2006; Chapple \& Kattenbelt, 2006; Bay-Cheng, Kattenbelt, Lavender, \& Nelson, 2010; Salter, 2010). Het theatrale kan zich door deze connectiviteit inmiddels intercultureel,

\footnotetext{
${ }^{203}$ Hier doel ik met name op de concrete omvang van de digitale ontwikkelingen: nagenoeg alle communicatie is tegenwoordig digitaal; de alom beschikbaarheid voor nagenoeg iedereen van digitale video-, audio- en communicatieapparatuur; de gevoeligheden die afgelopen jaren zijn komen bovendrijven rond privacy, big data en internationale dimensies aan openbaar dataverkeer.
} 
intermediaal en internationaal als sterk verbonden beschouwen met diverse andere culturele, performatieve domeinen. De resultaten van mijn casestudies wijzen erop dat deze verbindingsbewegingen zich niet meer alleen beperken tot esthetische categorieën van de theaterkunst, gehanteerd door regisseurs of uitvoerenden binnen de productie van theater, maar zich ook hebben uitgestrekt tot op het niveau van de concrete bedrijfsvoering en werking van vakinstituties als de gezelschappen, de podia, de opleidingen en - in mindere mate - de beleidsgremia, en hiermee tot op het niveau van het theatersysteem in zijn totaliteit. Op deze manier beschouwd is Lehmanns postdramatische gedachtegoed te beperkt gebleken om de reikwijdte van interculturele, intermediale en internationale ontwikkelingen in hun volle omvang te duiden. Zijn nieuwe theateresthetiek is tegen deze achtergrond slechts een van de onderdelen in het theater-, performance- en medialandschap gebleken. Niet alleen voorstellingen en werkwijzen van theatermakers zijn de afgelopen decennia in transitie geweest, het theatersysteem resoneerde in zijn totaliteit mee in de cultureel dynamische context. We kunnen zeggen dat Lehmanns beschrijving van wat hij performancetekst noemde (Lehmann, 1999, pp. 145-178), zich anno 2015 veel verder uitstrekt dan de gevestigde kunstcategorieën van theater en performance; wat hij toentertijd performancetekst noemde raakt inmiddels ook de vorm, organisatie en werking van alle vakinstituties die zich begeven op het gebied van het performatieve.

In de huidige theaterpraktijk treffen we de onthiërarchisering van theatrale middelen aan die Lehmann schetste als blauwdruk voor het theater van de toekomst. Dat wil niet zeggen dat nu bijvoorbeeld de rol van taal en tekst volledig uitgespeeld is en het wil evenmin zeggen dat er nu geen sprake meer is van bijvoorbeeld sturend leiderschap. In een theatersysteem zonder een gestandaardiseerde hiërarchie van middelen en organisatiestructuur zijn allerlei vormen van artistiek leiderschap en van tekstuele aansturing vandaag de dag echter mogelijkheden geworden in plaats van door een dwingende traditie voorgeschreven werkvormen of vanzelfsprekende kenmerken van kwaliteit. Toneelhuis Antwerpen wordt op een andere manier geleid dan het Nederlandse theatergezelschap De Warme Winkel; tekstmateriaal voor de TGA-voorstelling The Fountainhead (2014) kent een andere basis dan de gemiddelde voorstelling van Benjamin Verdonck; de research voor een voorstelling gebeurt bij Tryater totaal anders dan voor een theaterproductie van CREW, voor een performance op Oerol of voor het maken van een korte televisiefilm bij de VPRO. Bovendien kunnen story- of character driven games of een televisieserie een minstens even groot cultureel gewicht hebben als een toneeltekst van Shakespeare of als een film van Michelangelo Antonioni , Quentin Tarantino of Xavier Dolan. Het gaat anno 2015 om probleemloos naast elkaar bestaande en geaccepteerde mogelijkheden voor het inzetten van als dominant, residual of emergent beleefde theater-, performance- of mediamiddelen, van productiestrategieën of manieren van werken in een breed 
gedefinieerde artistieke praktijk. Er is daarbij nauwelijks nog sprake van een scherp gekaderde nationale canon of van een gekaderd specifiek toneelrepertoire. Gezelschappen en individuele kunstenaars zijn net als hun publiek meer of minder wereldwijd georiënteerd, meer of minder ingevoerd in het interculturele; ze zijn digital natives of digital immigrants (Prensky, 2001) ${ }^{204}$, maar in ieder geval hebben ze alle mogelijkheden binnen handbereik voor een wereldwijd perspectief op culturele ontwikkelingen. Meer mensen in Nederland en Vlaanderen zullen tegenwoordig weten dat HBO een Amerikaanse televisiezender is en welke series er door dit bedrijf zijn geproduceerd dan wat de laatste producties zijn van grote gesubsidieerde Nederlandse BIS-gezelschappen als TGA, Oostpool of het Ro Theater ${ }^{205}$. Dit heeft alles te maken met een substantiële verbreding van het culturele landschap zoals dat in de netwerksamenleving vorm krijgt. Lehmann sprak nog vrijwel uitsluitend over een nieuwe theateresthetiek voor gekaderde westerse theaterkunst, vijftien jaar later is deze gekaderde theaterkunst meer nog dan toentertijd een niche geworden in een grootschalig opgerekt en samenhangend hybride speelveld van het performatief spectrum. Daarbij moet worden aangetekend dat de regels en uitgangspunten op dit speelveld niet uitsluitend geformuleerd worden door theaterkunstenaars, maar evengoed door organisaties en instituties die naast deze producerende kunstenaars deel uitmaken van een samenhangend systeem: de diverse soorten podia en hun publiek, de gedifferentieerde kunstvakopleidingen en hun groeiende onderzoeksgerichtheid en het kunst- en cultuurbeleid van de overheid.

Uit mijn onderzoek naar de vier cases kunnen we de conclusie trekken dat drie van de vier theaterinstituties de afgelopen vijftien jaar transformaties ondergingen die opgevat kunnen worden als voortzetting en tevens verruiming van wat Lehmann in 1999 postdramatisch theater noemde. Hierbij dient opgemerkt te worden dat in het lopende discours noch door Lehmann, noch door Fischer-Lichte expliciet is ingegaan op de medeconstitutieve rol die opleidingen en beleidsgremia spelen bij het vormgeven van de professionele theater-, performance- en mediapraktijk. Ik heb dat nadrukkelijk wel gedaan. In mijn casestudies is zichtbaar geworden dat het incorporeren van het postdramatische niet beperkt bleef tot artistieke scheppingsprocessen in repetitielokalen, waar Lehmann voornamelijk over sprak, maar dat het ook doordrong tot in de praktische werkwijzen en organisatiestructuren van de vakinstituties: de

\footnotetext{
${ }^{204}$ Marc Prensky sprak in 2001 voor het eerst over digital natives. Hij definieerde daarmee mensen die geboren zijn na 1980 en wiens dagelijks leven voor het grootste deel gedigitaliseerd/gemediatiseerd is. Ze hebben nooit een andere (meer analoge) leefomgeving gekend. Mensen die voor 1980 geboren zijn en die Prensky digital immigrants noemt, kunnen wel enigszins overweg met digitale apparatuur, maar ze leven voor een deel vaak ook nog in de analoge wereld. Het digitale is voor hen niet de natuurlijke habitat die het is voor de natives.

205 Dit geldt evenzeer voor de Vlaamse situatie, al zullen daar de grote gezelschappen (NTGent, Toneelhuis Antwerpen en KVS Brussel) procentueel bij een groter publiek bekend zijn dan in Nederland (Hoeven, 2012).
} 
software (theateresthetiek) veranderde gaandeweg ook de hardware (theaterbedrijf, podium, opleiding). Bij de vierde casestudie, die van het overheidsbeleid ten aanzien van theater, zien we een minder eenduidig transformatiepatroon dan bij de andere drie. Op basis van de achtereenvolgende verhaallijnen waarlangs het Nederlandse theaterbeleidsdiscours zich heeft ontwikkeld, zijn periodes te traceren waarin de overheid zich gevoelig toont voor theatertransities en periodes waarin sprake lijkt van stagnatie in de relatie met een veranderende culturele context en samenleving. Daar waar bij de drie andere casestudies sprake is van incorporatie van nieuwe theateresthetische inzichten, is er in het theaterbeleidsdiscours sprake van een heenen-weerbeweging, sterk afhankelijk van de politieke kleur van de elkaar opvolgende kabinetten. De rizomatische verbindingen tussen verschillende kunstdisciplines (Deleuze \& Guattari), de polysystematische bewegingen tussen periferie en centrum (Even-Zohar) en de dynamische verhouding tussen emergente, dominante en residuele cultuuruitingen (Williams), raken drie van de vier theatersysteempijlers. De systeempijler van het Nederlandse theaterbeleid wordt er slechts sporadisch en zeker niet systematisch door geraakt.

Er is in de afgelopen decennia in diverse cultuurnota's van de overheid geschreven over interculturaliteit en diversiteit, over de groeiende rol van digitale cultuur en over een internationaal cultureel landschap dat belangrijk wordt naast een nationaal toneelbestel. Op het niveau van het theatersysteem als geheel echter, wordt er door dezelfde overheid nauwelijks of niet afgeweken van de bestaande theaterinfrastructuur, waarvan een belangrijk deel nog hoofdzakelijk ingericht is om zich vooral te wijden aan het conserveren van cultureel erfgoed. Dit, terwijl een groot deel van het publiek zich min of meer afkeert van het gesubsidieerde theateraanbod en zich juist verhoudt tot de gehele breedte van het hybride performatieve spectrum. We zouden kunnen zeggen dat de overheid structureel nog niet echt steekhoudende antwoorden heeft weten te formuleren op de statusstijging van populaire performatieve cultuuruitingen, die de lang als vanzelfsprekend geachte legitimering van subsidiering van het gevestigde theater onder druk zet.

\section{Discussie en aanbevelingen}

Wat zouden de onderzoeksresultaten kunnen betekenen voor de theaterpraktijk van de nabije toekomst? I formuleer hierna een aantal overwegingen en aanbevelingen op basis van de opbrengsten van het onderzoek.

Naast theatergezelschappen als Toneelhuis Antwerpen die zich trachten te verhouden tot een veranderende culturele context, ziet nog een deel van de geïnstitutionaliseerde gezelschappen het niet als strategisch van levensbelang om serieuze artistieke contacten te leggen op het spectrum buiten de traditionele 
theatersector. Op basis van de onderzoeksresultaten verdient het aanbeveling dat gesubsidieerde gezelschappen bijvoorbeeld coproducent worden van een Nederlandse filmproductie of spelerskapitaal aanleveren voor een Nederlandse of internationaal geproduceerde televisieserie dan wel bijdragen aan de research of scenarioontwikkeling daarvan. Theatergezelschappen zouden daarnaast de komende jaren, gekoppeld aan relevante onderzoeksprogramma's van lectoraten of op technische universiteiten, partner kunnen worden in practice based onderzoek naar immersieve media, gaming of naar toepassingen van 3D-technologie in de kunsten. In deze samenwerkingsscenario's zou het vergroten van intermediale en interculturele kennis en begrip meer gewicht moeten hebben dan het produceren van theatervoorstellingen tout court. Het moet voor theaterkunstenaars de komende decennia een uitdaging zijn om samenwerkingsverbanden op te zoeken met tot nu toe sectorvreemde partners op het performatieve spectrum en in diverse maatschappelijke sectoren (wetenschap, bedrijfsleven, zorg).

Podia als film, catwalk, poppodia, televisie, sociale media, festivals, dance events, community art-podia en hybride podia als de Verkadefabriek zijn in de samenleving normale podia geworden. Ze zijn in toenemende mate van belang voor ons culturele leven, maar worden formeel door veel van de betrokken actoren (theatergezelschappen, overheid, adviescolleges, koepelorganisaties, opleidingen) nog nauwelijks serieus genomen als potentiële bondgenoten binnen de discursieve orde van het theatersysteem. Veel van de traditionele theaterpodia hebben bovendien een minder geschikte vorm of organisatie, zijn vaak niet voldoende geëquipeerd of hebben een te afwijkende symbolische lading om voor bovengenoemde innovatieve allianties open te kunnen staan. Herijking van de rol van invloedrijke traditionele brancheorganisaties als bijvoorbeeld de Vereniging van Schouwburg- en Concertgebouwdirecties is tegen deze achtergrond noodzakelijk; er dienen zich aan de horizon andere serieuze gesprekspartners aan.

Tegen de tijdgeest in worden nog relatief veel conventionele podiumprojecten gerealiseerd. De exemplarische discussies over prestigieuze nieuw te bouwen schouwburgen in Den Bosch, Den Haag en andere Nederlandse steden gaan over grondprijzen, uitstraling, uitgaanscircuits, over verdienmodellen en over city branding, terwijl ze zouden moeten gaan over een veranderende tijd, over onder invloed daarvan veranderend menselijk gedrag, over intermedialiteit en interculturaliteit, en over de maatschappelijke rol van kunst.

Eigentijdse theateropleidingen dragen er zorg voor dat studenten zich mediakritisch kunnen verhouden tot de eigen sector, de culturele context en de samenleving. Zij dienen het belang en de veelzijdigheid van artistieke strategieën in te 
zien en zich het vermogen om deze te ontwikkelen eigen te maken. ${ }^{206}$ Het brede performatief spectrum biedt ze daar meer kansen toe dan de gekaderde smalle traditionele theatersector. Naast het verbreden van het beroepsperspectief is er voor theateropleidingen een rol weggelegd als kenniscentra en bondgenoten van de wetenschap in het onderzoek naar nieuwe kunstvormen en naar de maatschappelijke betekenis van de veelheid aan producenten en podia op het performatief spectrum. De academische wereld zou, meer dan nu het geval is, in kunstenopleidingen potentiële onderzoeksbondgenoten kunnen zien bij het ontrafelen van vraagstukken die opgeroepen worden door de nieuwe tijd. Het is zaak er daarbij op toe te zien dat toekomstig onderzoek op dit vlak zich niet eenzijdig laat leiden door instrumentele vernieuwing van productiemethoden of marketingtechnieken rond het traditionele theater (cultureel ondernemerschap), maar ook door artistieke strategieën in de richting van het blootleggen van structuurveranderingen van het performatieve. De contacten tussen de lectoraten binnen de theater-, performance- en mediasector, en de geesteswetenschappen, neurowetenschappen en technologische faculteiten zouden daartoe in het komende decennium aangetrokken kunnen worden.

Het paradoxale aan het systeem van culturele sturing door middel van subsidies dat het theaterbeleid van de overheid over een periode van zeventig jaar heeft gekenmerkt, is dat hoe explicieter de overheid stuurde, hoe meer de samenleving ervoor koos om dit stimuleren te negeren en te kiezen voor andere, vaak meer populaire, vormen van cultuurbeleving. Het grote publiek keerde zich als het ware af van de smalle gevestigde 'theaterkunstkerk' waartoe de overheid het met goede bedoelingen probeerde te verleiden. Herstel van de dialoog met de samenleving vraagt om een drietal veranderingen. Door een bredere visie op kunst- en cultuurbeleving te ontwikkelen kan de overheid recht doen aan het culturele gewicht dat het performatief spectrum in zijn totaliteit heeft in de samenleving. Daarnaast zal de overheid een nieuw beleidsinstrumentarium dienen te ontwikkelen; voor nieuwe vormen van cultuurbeleving is financiering door subsidie niet meer op dezelfde manier nodig als in het verleden voor de traditionele kunstensectoren. Tenslotte zou de overheid ook andere partners actief bij het nieuwe beleidsdiscours moeten gaan betrekken dan alleen die van de gevestigde canonieke kunsten. We kunnen bij dit alles spreken over de noodzaak van een overheid die het weer aan zou durven om meerdere actoren in het theatersysteem een onderzoeksopdracht mee te geven, te

\footnotetext{
${ }^{206}$ Met studenten dienen niet alleen hun kansen op een sectorgebonden arbeidsmarkt voor acteurs, regisseurs, theaterdocenten en theatervormgevers besproken te worden, maar ook artistieke strategieën in bredere zin. De lessen ethiek en moraal die de makers verpakten in de Deense televisieserie Borgen, of de keuzes van artistiek leider Theu Boermans van het Nationaal Toneel bij het vormgeven van musicals als Soldaat van Oranje en Anne, zouden in dit verband als interessante casestudies onder hun aandacht gebracht kunnen worden.
} 
vergelijken met de beweging die minister Klompé maakte in het begin van de jaren zeventig; Marga Klompé revisited. Zij stelde toentertijd de vraag: om wat voor soort theater vraagt deze tijd? Het is ook nu een uitgelezen en verantwoordelijke rol voor de overheid om de complexe relatie tussen populaire culturen en de traditionele canonieke theatersector te exploreren, om zo in dialoog met de samenleving en met het brede performatief spectrum te trachten achter het 'soortelijk gewicht' te komen van games, van het werk van André Rieu, van televisiedramaseries, van immersieve media, van videokunst, van multimediale theaterervaringen, van mode en popmuziek.

Passend in het concept van de netwerksamenleving zou door betrokken actoren niet meer alleen gedacht moeten worden aan het overeind houden van de gevestigde theatersector als conserveringsmachine van canoniek cultureel erfgoed, maar vooral ook aan het ontrafelen en verhelderen van de samenhang van dat erfgoed met performatieve aspecten in nieuwe, emergente kunstdomeinen. De door de overheid te faciliteren gezelschappen zouden in het licht van het bovenstaande in veel gevallen structureel iets anders kunnen zijn dan wat voorheen traditionele toneelgezelschappen waren. Maar ook gevestigde gezelschappen zouden door wisselende allianties en assemblages steeds korter of langer gelieerd kunnen worden aan het niet-theatrale, aan niet per definitie artistieke partners of werkterreinen. ${ }^{207}$ Van groot belang is dat er in ieder geval bij voorkeur voorbij gangbare theatergezelschapscategorieën gedacht gaat worden en meer in termen van laboratoria, die de relatie tussen samenleving en performatief spectrum gaan exploreren. Net zoals Apple en Google 14-jarige digital natives beschouwen als serieuze gesprekspartners ${ }^{208}$ en in hen investeren, zou de overheid meer kunnen investeren in laboratoria of werkplaatsen waar wordt nagedacht over artistieke toepassingen van data-analyse en 3D-printen, over opschaling van het scenarioschrijven, over researchprocessen voor film, documentaires en televisiedrama, over story driven games, beeldanalyse en technology driven art, en dit alles bij voorkeur op het niveau van de BIS-instellingen en in samenspraak met bestaande

\footnotetext{
${ }^{207}$ Er vinden wat dat aangaat al diverse inspirerende initiatieven plaats, eerder ondanks dan dankzij een genereuze overheid. Ik wijs hier op recent werk van het Vlaams-Nederlandse acteurscollectief Wunderbaum. In februari 2013 startten zij een vierjarig project, The New Forrest. In het project wordt toegewerkt naar de constructie van een nieuwe samenleving, waarbij afscheid genomen wordt van de democratie zoals wij die kennen. Het collectief werkt hierin samen met CEO' s uit het bedrijfsleven, met communicatiebureau KesselsKramer, met wijkagenten, gentechnologen, architectenbureau ZUS, dansers, filmers, en diverse wetenschappers waaronder de socioloog Willem Schinkel.

${ }^{208}$ Google en Apple nodigen regelmatig zeer jonge talenten uit van over de gehele wereld om mee te denken over nieuwe digitale ontwikkelingen. In oktober 2014 was er veel aandacht in de media voor het 15-jarige programmeertalent Puck Meerburg uit Delft, die al vanaf zijn elfde conferenties toespreekt over zelfontwikkelde apps en digitale oplossingen voor programmeerproblemen.
} 
theaterinstituties, stakeholders op het performatief spectrum, relevante onderzoekscentra en faculteiten.

\section{De rol van kunst en het performatief spectrum}

In de cultureel dynamische context van de netwerksamenleving hebben theaterinstituties, zoals we hebben gezien, transformaties ondergaan in de richting van een performatief spectrum. Ik wil deze studie besluiten met een beschouwing over de werking en de maatschappelijke betekenis van dit performatieve spectrum zoals ik die zie. Om mijn kijk op de relatie tussen kunst en samenleving te verhelderen, maak ik hier graag gebruik van de visie van de Britse auteur Jeanette Winterson. Zij definieerde vier manieren waarop kunst relevant zou kunnen zijn en gebruikt daarbij vier metaforen: de kunst als beker, als jas, als remedie en als mes (Winterson, 2007). ${ }^{209}$ De beker staat voor het koesteren van de herinnering, van belangrijk cultureel erfgoed bijvoorbeeld, en van ruimte voor bespiegeling en contemplatie. De jas staat voor alles wat een mens in de loop van zijn leven opdoet aan kunstzinnige ervaringen, die daarmee een deel van zijn persoonlijkheid worden. Winterson spreekt tevens over kunst als een remedie tegen een wereld die al te zeer wordt bepaald door markt, munt, machine en management; de remedie is als het wakker schudden, zodat mensen anders, bewuster gaan leven. Als vierde staat bij haar het mes voor kunst als wapen tegen al te opdringerige oppervlakkigheid van popular culture. Met de kunst als mes kan de hedendaagse mens zich volgens Winterson een weg banen door de Google-, CNN- en Wikipediajungle en onderscheid leren maken tussen wat waardevol is en wat niet (Winterson, 2007).

In de manier waarop Winterson de relevantie van kunst normatief definieert ga ik ver mee, de eerste drie functies onderschrijf ik onmiddellijk. Ik kan het echter niet eens zijn met haar metaforisch gebruik van een mes om alles wat popular culture is ondubbelzinnig af te wijzen. In mijn onderzoek constateer ik dat het vormgeven van een geëngageerd openbaar leven zich tegenwoordig voor heel veel mensen minstens net zo vaak laat verpakken in een muziekclip op YouTube, in een computergame, in een televisieserie, in een film of in een community art-project, als in een Shakespeareenscenering door een gevestigd theatergezelschap. Al deze categorieën, inclusief de Shakespeare-enscenering overigens, en hun publiek, kunnen in mijn perspectief opgevat worden als één grote rizomatische performatieve verzameling. Dit is hoe de samenleving zich langzaam aan het verhouden is tot kunst en cultuur. Aanvankelijk perifere cultuuruitingen zijn zich een weg aan het banen naar het centrum van de cultuurbeleving. Winterson lijkt daar blind voor. Ik ben niet mordicus tegen een

\footnotetext{
${ }^{209}$ Op donderdag 13 december 2007 sprak de Britse schrijfster Jeanette Winterson haar visie op de maatschappelijke rol van kunst uit in de derde Belle van Zuylen lezing te Utrecht.
} 
mesfunctie voor kunst, maar waar ik in Wintersons redenering een ongenuanceerd groot slagersmes vermoed, denk ik meer aan een uiterst genuanceerd gebruik van een precisie-instrument als een gamma knife. ${ }^{210}$

Er vinden, zoals we in de casestudies gezien hebben, voortdurend allianties plaats tussen verschillende traditionele en populair culturele ensceneringpraktijken waardoor het gevestigde theatrale assembleert met andere culturele tradities. Dit levert ander repertoire op dan het voorheen nationaal of canoniek gekaderd theaterrepertoire, een ander dan traditioneel theaterpubliek en andere dan voor de gevestigde theaterinstituties gangbare werkwijzen en publieksbenaderingen. De betekenis die kunst in onze netwerksamenleving kan hebben, wordt door deze spectrale verbreiding volgens mij sterk vergroot. Want juist met een kunst die zich bij het bevragen van de tijd verbonden weet met een breed spectrum, inclusief populaire cultuur, kan het publiek zich het onderscheid eigen maken tussen datgene wat als duurzaam en waardevol beleefd kan worden en wat niet. Juist een kunst die gerelateerd is aan de veelzijdigheid van de hedendaagse samenleving, zou een remedie kunnen zijn tegen kwalijke kanten van diezelfde samenleving en zou mensen bewuster kunnen doen leven. Van de actoren in het theatersysteem is het met name de overheid, die een rol zou kunnen spelen in het onderzoek naar kunst als remedie, met de inzet van een beleidsmatig equivalent van een gamma knife als cultuurbeleidsstrategie om de relatie tussen kunst en samenleving te herdefiniëren.

De beschreven nieuwe verbanden in het culturele veld veranderen de facto de werking, positie en de structuur van de gevestigde gesubsidieerde theatersector als (voormalige) culturele hoofdrolspeler (Oosterbaan Martinius, 2010). Uit de resultaten van de gevalstudies trek ik de conclusie dat 'Het Theater' als culturele hoofdsector in feite niet meer bestaat; de theatersector is in zijn geheel een niche of subcultuur geworden binnen een spectrum van meerdere performatieve subculturen. Het performatief spectrum is in zijn totaliteit de kritische en reflectieve rol gaan vervullen die voorheen de traditioneel gekaderde kunsten vervulden. Ik beschouw dit opgaan van theater in een verzameling genetwerkte subculturen als een organische ontwikkeling die bij een netwerksamenleving hoort en waar we ons toe hebben te verhouden. Dit netwerk van bondgenoten heeft door zijn hybride culturele veelzijdigheid potentieel een veel groter bereik in de openbaarheid dan wat het theater als standing alone kunstendiscipline ooit heeft gehad. Om mee te kunnen gaan in een dergelijk perspectief is het voor gevestigde theaterinstituties noodzakelijk om de blikrichting te draaien: van een aansturing door premissen uit het verleden naar een onderzoeksmatige nieuwsgierigheid naar wat zich op dit moment aan het voltrekken is. Een dergelijke wisseling van blikrichting zou voor het Nederlandse

\footnotetext{
${ }^{210}$ Een gamma knife is een nucleair bestralingstoestel met de nauwkeurigheid van een chirurgisch mes, dat kan worden ingezet voor de radio-chirurgische precisiebehandeling van uiteenlopende aandoeningen.
} 
cultuurbeleidsdiscours betekenen dat er een heel andere interpretatie gegeven wordt aan het begrip cultureel ondernemerschap.

Kunstsocioloog Pascal Gielen beschrijft in zijn essay 'Artistieke praxis en de neoliberalisering van de onderwijsruimte' (Gielen, 2012) hoe een groot deel van de huidige theatersector inclusief de overheid geobsedeerd is door dat begrip. ${ }^{211} \mathrm{We}$ hebben dat ook gezien in hoofdstuk 6. Cultureel ondernemerschap wordt daarbij eenzijdig economisch geïnterpreteerd, als gericht op winstmaximalisatie. Als winst in de cultuurbeleidscontext opgevat zou worden in termen van een rijker cultureel leven, het verspreiden van kritisch en reflectief vermogen, de optimalisatie van intermenselijke vrijheid, van gemeenschapszin, van begrip voor de ander, van engagement en van schoonheid, dan zou dat begrijpelijkerwijs een groot goed zijn voor welke gemeenschap dan ook. Het al of niet gunstig zijn van de omstandigheden waarin dit rijkere culturele leven tot stand zou kunnen komen, heeft alles te maken met het al of niet omarmen van de ambitie om het performatief spectrum te begrijpen, om de samenhang tussen canoniek en experimenteel theater en andere, emergente vormen van performatieve uitingen te doorgronden. Daarbij zou, gelet op de uitkomsten van dit onderzoek, het accent kunnen liggen bij het investeren in onderzoek naar diepte, betekenis en samenhang op het spectrum, meer dan bij het geprivilegieerd ondersteunen van een selectie van canonieke dan wel experimentele kunstvormen. Overheden op het gebied van kunst en cultuur zullen, als ze interculturele, intermediale en internationale signalen serieus nemen, op zoek moeten naar andere dan de gevestigde gesprekspartners in het huidige theatersysteem. Om de relatie tussen kunsten en samenleving te herstellen, zou het moeten gaan om nieuwe serieuze culturele gesprekspartners op het spectrum, die de door Winterson geschetste rollen voor de kunst mogelijk nu al vervullen. Dit gaat niet over het inruilen van het canonieke traditionele theatersegment voor alles wat nieuw is, dit gaat over het uitbouwen van de ambitie om overeenkomsten en verschillen te definiëren tussen het gevestigde theater en de rest van het spectrum. Het gaat erom dat we ons weer fundamenteel af moeten durven vragen hoe theater- , performance- en mediatalen in 2015, 2017 of 2020 zouden kunnen werken en hoe ze nodig zijn in de samenleving. De gevalstudies tonen ons welke transformaties de gezelschappen, de podia en de opleidingen op dit moment ondergaan. Gezelschappen laten zich in toenemende mate in met gedifferentieerd repertoire inclusief performances en media, hun organisatiestructuur en werkwijze verandert hierdoor ingrijpend. Podia zijn niet meer uitsluitend gemodelleerd naar negentiende-eeuwse podiumkunstenconventies en

\footnotetext{
${ }^{211}$ Gielen (2012, pp. 86-103) beschrijft de biotoop van een kunstenaar als samengesteld uit vier domeinen: de domestieke ruimte; de ruimte van de beroepsgemeenschap of peer group; de ruimte van de markt; en de civiele ruimte. Volgens Gielen is het voor kunstenaars zaak om een zekere balans in stand te houden tussen deze vier ruimtes.
} 
zullen dat steeds minder zijn. Theateropleidingen bedienen niet alleen het gevestigd theater maar houden zich over de gehele breedte van het performatief spectrum gericht bezig met theater, performance en media, met onderzoek op deze terreinen en hun onderlinge samenhang. Een op de toekomst gericht theaterbeleid zou vanuit een bredere visie op kunst en cultuur en met herijkte beleidsdoelstellingen kunnen bijdragen aan het begrijpen van de omvang, de samenhang en de diversiteit van het performatief spectrum. Daarmee zou de overheid de rol spelen die haar past in het onderzoek naar de betekenis van kunst voor de hedendaagse netwerksamenleving: het onderscheiden van wat waardevol is en wat niet. 



\section{Referenties en literatuur}

\section{Primaire bronnen}

Arts Faculty Maastricht/Zuyd Hogeschool (2012). Kunstvakonderwijs van de 21 eeuw. Maastricht: Auteur.

Commissie Alons (2006). Naar een fonds voor muziek, dans en theater. Advies over een nieuwe landelijke fondsenstructuur voor de podiumkunsten. Utrecht: Auteur.

Commissie De Boer (1984). Eindrapport van de Commissie Landelijk Toneelbestel.

Rijswijk: Staatsuitgeverij.

Commissie Dijkgraaf (2010). Onderscheiden, verbinden, vernieuwen, de toekomst van het kunstonderwijs. Advies van de Commissie Dijkgraaf voor een sectorplan kunstonderwijs. Den Haag: Koninklijke De Swart.

Defresne, G., Groeneveld, B., Meerten, H. van, Rijkens, A., \& Sterneberg, F. (1944). Ontwerp voor een regeling van het toneel na de oorlog. (z.p).

Desmet, Y. (juni 2007). De regisseur als DJ. In E. Jans (red.), Toneelg(e)ruis, 1(2), $125-$ 140.

HBO-raad (2003). Eindrapport van de visitatiecommissie Theater. Den Haag: Auteur. Horen, L. van (2007). De Verkadefabriek. 's-Hertogenbosch: Verkadefabriek.

Jans, E. (red.). (2006b). Toneelg(r)uis, 1(0). Antwerpen.

Jans, E. (2006c). Theatermaken: een permanent proces van herschikken. Interview met Guy Cassiers. In E. Jans (red.), Toneelg(e)ruis, 1(0), 25-33.

Jans, E. (2007). Een geschiedenis van de wereld in $101 / 2$ hoofdstuk. Een verslag van het werkproces door Valentine Kempynck in gesprek met Erwin Jans. In E. Jans (red.), Toneelg(r)uis, 2(2), 165-171.

Jans, E. (2008). Een beginpunt, een eindpunt, in elk geval een keerpunt. Een vraaggesprek met Lotte van den Berg. In E. Jans (red.), Toneelg(e)ruis, 3(3), 9297.

Kort, P. de, \& Olaerts, A. (2014). Over Grenzen. Kritische reflectie Toneelacademie Maastricht. Maastricht: Toneelacademie Maastricht.

Ministerie van CRM (1972). Discussienota Kunstbeleid. 's-Gravenhage: Staatsuitgeverij. Ministerie van CRM (1976a). Nota Kunst en kunstbeleid. 's-Gravenhage:

Staatsuitgeverij. 
Ministerie van CRM (1976b). Nota Toneelbeleid. 's-Gravenhage: Staatsuitgeverij.

Ministerie van OCW (1999a). Zicht op kwaliteit. Ontwikkeling van artistiek talent in het kunstonderwijs. Den Haag: Ministerie van OCW.

Ministerie van OCW (1999b). Cultuur als confrontatie. Uitgangspunten voor het cultuurbeleid 2001-2004. Den Haag: Sdu.

Ministerie van OCW (1999c). Schwartz, M. Digitale media in de technologische cultuur. Perspectieven voor een kunst- en cultuurbeleid. Den Haag: Sdu.

Ministerie van OCW (2002). Cultuurbeleid in Nederland. Den Haag: Sdu.

Ministerie van OCW (2003). Meer dan de som. Den Haag: Sdu.

Ministerie van OCW (2005). Verschil maken. Herijking cultuurnotasystematiek. Den Haag: Sdu

Ministerie van OCW (2007a). Kunst van Leven; hoofdlijnen cultuurbeleid. Den Haag: Koninklijke De Swart.

Ministerie van OCW (2007b). Wijziging Regeling subsidies en uitkeringen cultuuruitingen. Den Haag: Auteur

Ministerie van OCW (2010). Kunst in Cijfers. Den Haag: Koninklijke De Swart.

Raad voor Cultuur (2010). Netwerken van betekenis. Netwerktaken in digitale cultuur en media. Advies van de Raad voor Cultuur aan Staatssecretaris van OCW, Mevr. M. Van Bijsterveld-Vliegenthart. Den Haag: Auteur.

Ministerie van OCW (2011). Meer dan kwaliteit: een nieuwe visie op cultuurbeleid. Den Haag: Auteur.

Ministerie van WVC (1982). Eindrapport van de Werkgroep Koppelsubsidies. Den Haag: Staatsuitgeverij.

Ministerie van WVC (1985). Notitie Cultuurbeleid. Rijswijk: Staatsuitgeverij. Ministerie van WVC (1987a). Brief over het kunstbeleid. Rijswijk: Auteur. Ministerie van WVC (1987b). Plan voor het kunstbeleid 1988-1992. Rijswijk: Auteur. Mostert, P. \& Van Bakelen, M. (1999). Profiel van de sector theater/drama. Beroepsprofielen en startkwalificaties. Utrecht: Projectorganisatie Kunstvakonderwijs.

Netwerk Theater - Werkgroep Opleidingsprofiel Theater (2002). Opleidingsprofiel Theater. Uitstroomprofielen Acteur en Theatermaker. Utrecht: Auteur.

Netwerk Theater (2007). Herziening Opleidingsprofiel Theater - Uitstroomprofiel Acteur en Theatermaker. Notitie ter bespreking met de beroepspraktijk. Utrecht:

Auteur.

Netwerk Theater (2009). Hier en Nu. Position Paper Nederlandse theaterscholen 2009. Utrecht: Auteur.

NVAO (2008). Accreditatierapportage NQA/visitatiedata. Utrecht: Auteur.

NWO (2007). Culturele Dynamiek. Onderzoeksprogramma 2007 - 2013.

Programmanotitie. Den Haag: Auteur. 
Projectorganisatie Kunstvakonderwijs (1999). Beroep Kunstenaar. Rapport van de projectorganisatie kunstvakonderwijs. Voorstellen voor inhoud en organisatie van het kunstvakonderwijs in Nederland. Utrecht: Auteur.

Putten, J. van der (2008). Analyse theaterprogrammering en marketing. Den Bosch: Verkadefabriek.

Raad voor Cultuur (2008). Basisinfrastructuur 1.0. Advies vierjaarlijkse cultuursubsidies voor instellingen, sectorinstituties en fondsen voor de Basisinfrastructuur. Den Haag: Auteur.

Raad voor Cultuur (2014). De Cultuurverkenning. Ontwikkelingen en trends in het culturele leven in Nederland. Den Haag: Auteur.

Toneelacademie Maastricht (2000). De Toneelacademie Maastricht: 2000 en verder. Maastricht: Auteur.

Toneelacademie Maastricht (2008). De Kleur van Maastricht. Opleidingsvisie Toneelacademie Maastricht. Maastricht: Auteur.

Toneelacademie Maastricht (2014). Theater van de 21e eeuw: traditie en vernieuwing. Maastricht: Auteur.

Toneelacademie Maastricht (2015). Leerplan Theater-Uitstroomprofiel ActeurAfstudeerrichting Performer. Maastricht: Auteur.

Toneelhuis Mission Statement (n.d.). Retrieved Oktober 14, 2014, from http://toneelhuis.be/\#!/nl/page/toneelhuis-mission-statement

Toneelhuis (2008) Aanvraag voor een vierjarige subsidie voor het geheel van de werking door Toneelhuis Antwerpen bij het Vlaams Ministerie voor Cultuur, Jeugd, Sport en Media. Antwerpen: Auteur.

Toneelhuis (2011). Aanvraag van een meerjarige subsidie voor het geheel van de werking (periode 2013-2016). Antwerpen: Auteur.

Verkadefabriek (2008). Bedrijfsplan Verkadefabriek. 's-Hertogenbosch: Auteur. Verkadefabriek (2009). Bedrijfsplan Verkadefabriek. 's-Hertogenbosch: Auteur. Verkadefabriek (2010). Bedrijfsplan Verkadefabriek. 's-Hertogenbosch: Auteur. Verkadefabriek (2011). Toekomstvisie Verkadefabriek [\& Gemeente's-Hertogenbosch] 's-Hertogenbosch: Auteur.

Verkadefabriek (2012). Bedrijfsplan Verkadefabriek. 's-Hertogenbosch: Auteur. Verkadefabriek (2012). Programma 2012 - 2013. 's-Hertogenbosch: Auteur. 


\section{Interviews}

Tussen de zomer van 2007 en die van 2012 heb ik in het kader van de vier gevalstudies voor dit boek een aantal interviews afgenomen van belangrijke actoren binnen de organisaties die ik heb bestudeerd. Met sommigen van hen heb ik meerdere malen gesproken. Naast deze formeel georganiseerde interviews heb ik veel informele gesprekken gevoerd met collega's en studenten van de Toneelacademie, van andere kunstvakopleidingen en faculteiten, met mijn collegaonderzoekers van het lectoraat Autonomie en Openbaarheid in de Kunsten, en met diverse professionals uit de hedendaagse theater-, performance- en mediapraktijk. In dit korte overzicht neem ik echter alleen formeel afgenomen interviews op, in chronolische volgorde.

Guy Cassiers en Erwin Jans, respectievelijk artistiek directeur en dramaturg van Toneelhuis Antwerpen, werden in Antwerpen door Havens geïnterviewd op 7 februari, 4 april en 13 juni 2008.

Peter Missotten, toentertijd lid van de artistieke staf van Toneelhuis Antwerpen, werd in Maastricht door Havens geïnterviewd op 13 februari 2008.

An-Marie Lambrechts, artistiek coördinator van Toneelhuis Antwerpen, werd door Havens geïnterviewd in Antwerpen op 13 juni 2008.

Emile Zeldenrust en Mustafa Duygulu, van 2005-2009 studenten op de performanceopleiding in Maastricht en betrokken bij een project bij KesselsKramer, werden door Havens geïnterviewd in Maastricht op 16 juni 2008.

Jan van der Putten, algemeen directeur van de Verkadefabriek in 's-Hertogenbosch, werd door Havens geïnterviewd in 's-Hertogenbosch op 9 september 2008 en 5 november 2008.

Arjen Klerkx, video-ontwerper bij de producties van Guy Cassiers, werd door Havens geïnterviewd in Amsterdam op 18 oktober 2008.

Mustafa Duygulu, afgestudeerd als performer en actief filmer/acteur, werd door Havens geïnterviewd in Amsterdam op 11 mei 2009.

Joram Lürsen, Nederlands filmregisseur, werd door Havens geïnterviewd in Den Bosch op 9 juni 2009.

Rodney Weterings, van 2006 tot 2011 wethouder (PvdA) Cultuur van de Gemeente Den Bosch, werd door Havens geïnterviewd in 's-Hertogenbosch op 7 december 2010.

Madeleine Matzer, artistiek leider van Matzer theaterproducties te 's-Hertogenbosch, huisgenoot/gebruiker in de Verkadefabriek, werd door Havens geïnterviewd in 's-Hertogenbosch op 11 februari 2010. 
Theo van Dooremalen, zakelijk directeur van het festival November Music,

huisgenoot/gebruiker in de Verkadefabriek, werd door Havens geïnterviewd in

's-Hertogenbosch op 11 februari 2010.

Piet-Jan Dusee, artistiek leider van Productiehuis Brabant, huisgenoot/gebruiker in de Verkadefabriek, werd door Havens geïnterviewd in 's-Hertogenbosch op 11 februari 2010.

\section{Literatuur}

Abbing, H. (2009). Van hoge kunst naar nieuwe kunst. Groningen: Historische Uitgeverij Groningen.

Ackerman, V., \& Hendriks, R. (2010). Speciaal nummer: Industrieel Erfgoed - Zes thema's voor hergebruik. DAAD - Cahier \# 7.

Adams, T. (2010, 9 oktober). Het publiek staat op steeds meer afstand van de kunst. NRC Handelsblad, p. O\&D9.

Adriaanse, A., Nieuwenhuis, C., Oosten, M. van, \& Wijnhoud, G. (2006). Nieuw. 20 Jaar Multicultureel Theater. Amsterdam: Uitgeverij International Theatre and Film Books.

Appadurai, A. (1996). Modernity at Large, Cultural Dimensions of Globalization. Minneapolis and London: University of Minnesota Press. [terugplaatsen??]

Auslander, P. (1999). Liveness. Performance in a mediatized culture. London/New York: Routledge.

Austen, S. (red.). (1980). Margetheater in Nederland, Utrecht: Spectrum.

Austin, J.L. (1955). How to Do Things with Words. Cambridge, MA: Harvard University Press.

Baricco, A. (2010). De Barbaren. (M. Smits, vert.). Amsterdam: Uitgeverij De Bezige Bij. (Oorspronkelijke uitgave 2006)

Barnes, J. (1991). Een geschiedenis van de wereld in 10 1/2 hoofdstuk. (E. Hoog, vert.). Amsterdam: Uitgeverij De Arbeiderspers. (Oorspronkelijke uitgave 1989)

Bay-Cheng, S., Kattenbelt, C., Lavender, A., Nelson, R. (Eds.). (2010). Mapping Intermediality in Performance. Amsterdam: Amsterdam University Press.

Benjamin, W. (1985). Het kunstwerk in het tijdperk van zijn technische reproduceerbaarheid, en andere essays (H. Hoeks, vert.). Nijmegen: SUN. (Oorspronkelijke uitgave 1936)

Benschop, R. (2011a). I'll be Gone Again, Documenting the Virtual Body. Retrieved January 6, 2015, from http://www.researchcatalogue.net/view/5496/5497

Benschop, R. (2011b). Wij die fluiten in de stilte als kristallen glazen. Virtualiteit, theatraliteit, radicaliteit. Retrieved January 6, 2015, from http://www.thevirtualbody.org/downloads/files/WijdieCrewBrussels.pdf 
Berg, N. van den, Marlet, G., Ponds, R., \& Woerkens, C. van (red.). (2011).

Podiumpeiler. Een monitor voor podiumkunsten en muziekindustrie in Nederland. Utrecht: Uitgevoerd door 'Atlas voor Gemeenten' in opdracht van Muziek Centrum Nederland en Theater Instituut Nederland.

Berg, S. van den. (2009). Stille crisis in de kleine zaal. TM, 13(4), 36-39.

Berg, S. van den (2011). Risicovol theater. Boekman, tijdschrift voor kunst, cultuur en beleid, 23(nr.89), 78-82.

Bertsch, Y. \& Filz, F. (2003). Verder mag alles. Een handboek voor ensembleimprovisatie. Amsterdam: International Theatre \& Film Books.

Boletsi, M. (2010). Barbarism, Otherwise. Studies in Literature, Art, and Theory (proefschrift Universiteit Leiden). Leiden: Universiteit Leiden.

Boorsma, M. (1998). Marketing van theater en andere kunsten. Vergroting van publieksdeelname in theorie en praktijk. Amsterdam: Boekmanstudies.

Boorsma, M. (2001). A Network approach to art markets. In Nordic Theatre Studies 14, 92-108.

Borgdorff, H. (2009). Artistiek onderzoek in het geheel der wetenschappen. Krisis. Tijdschrift voor actuele filosofie, Issue 1. Retrieved May 29, 2013, from http://www.gu.se/digitalAssets/1322/1322693_artistiek-onderzoek-in-hetgeheel-der-wetenschappen.pdf

Borgdorff, H. (2012). The Conflict of the Faculties. Perspectives on Artistic Research and Academia (proefschrift Universiteit Leiden). Leiden: Leiden University Press.

Bork, R. van. (2012). Popmuziek hoor je overal. Vijftig jaar popmuziek in Nederland. In W. Rosenboom (red.), Erfgoed Amateurkunst en maatschappij 1950 - 2010. Maatschappelijke ontwikkelingen en hun invloed op de amateurkunst (pp. 2024). Utrecht: Kunstfactor.

Bourriaud, N. (2009). Altermodern. Retrieved May 27, 2013, from http://www.kunstgeschichte.tuberlin.de/fileadmin/user_upload/ArTUs/Materialien\%20SoSe\%202013/Franke/ bourriaud\%20altermodern.pdf

Broek, A. van den., Haan, J. de., \& Huysmans, F. (2009). Cultuurbewonderaars en cultuurbeoefeniaars. Trends in cultuurparticipatie en mediagebruik. Den Haag: Cociaal Cultureel Planbureau.

Bruijn, P. de (2008, 8 oktober). De schoonheid van een onttakeld mannenlijf. NRC Handelsblad. Retrieved December, 12, 2008, from http://vorige.nrc.nl/film/article2014717.ece/Hunger

Buijs, M. (1994, 14 oktober). Het publiek nam zelf de stoelen mee. de Volkskrant. Buijs, M. (1996, 15 juni). Passie voor kunst. de Volkskrant. Retrieved May 21, 2013, from http://www.volkskrant.nl/dossier-archief/passie-voor-kunst $\sim a 440200 /$ 
Buikema, R. \& Meijer, M. (red.). (2004). Kunsten in Beweging, Cultuur en migratie in Nederland. 1980-2000. Den Haag: Sdu Uitgevers.

Callon, M. (1986). Some elements of sociology of translation: domestication of the scallops and the fishermen of St. Brieuc Bay. In J. Law (Ed.), Power, Action and Belief: A New Sociology of Knowledge? (pp. 169-223). London: Routledge.

Carlson, M. (2003) What is Performance? In M. Huxley \& N. Witts (Eds.), The Twentieth Century Performance Reader (pp. 146-153). London and New York: Routledge. (Original work published 1996)

Carvalho, H. (2011, 29 september). Ik wil zingen als virus en kristal. NRC Handelsblad, p. 2 CS.

Castells, M. (1996). The Information Age: Economy, Society and Culture. Vol. I: The Rise of The Network Society. Oxford: Blackwell.

Chapple, F. \& Kattenbelt, C. (2006). Key Issues in Intermediality in theatre and performance. In F. Chapple \& C. Kattenbelt (Ed.), Intermediality in Theatre and Performance. Amsterdam and New York: Rodopi.

Cherkaoui, S.L. (2008). State of the Union. Retrieved December 12, 2011, from http://www.dansendansen.be/ckfinder/userfiles/files/State-of-the-Union--08--Sidi-Larbi-Cherkaoui.pdf

Cherkaoui, S.L. (2008). State of the Union [Video opname]. Retrieved December 12, 2011, from https://www.youtube.com/watch?v=OSHGFEZ7EP4

Daamen, M. \& Meijler, J. (red.). (2012). Tien jaar Expanding Theatre. Amsterdam: Stadsschouwburg Amsterdam

Debord, G. (1976). De Spektakelmaatschappij. (J. Kloosterman \& R. van der Kraats, vert.) Baarn: Het Wereldvenster. (Oorspronkelijke uitgave 1971).

De Wit, D. (2002). De ontwikkeling van nieuwe artistieke praktijken. Etcetera. Tijdschrift voor Podiumkunsten, 20(82), 26-28.

Deleuze, G., \& Guattari, F. (2004). Rizoom (R. Sanders, vert.). Utrecht: Spreeuw, libertaire uitgeverij. (Oorspronkelijke uitgave 1976)

Deleuze, G., \& Guattari, F. (2007). A thousand plateaus: vol. 2 of capitalism and schizophrenia. (B. Massumi, Trans.). Minneapolis: University of Minnesota Press. (Original work published 1980)

De Somviele, C. (2011). Lexicon. In C. Swyzen \& K. Vanhoutte (red.), Het Statuut van de taal in het post-dramatische theater (pp. 193-208). Antwerpen: University Press Antwerpen.

Ditshuyzen, I. van (Producent), \& De Boer, L. de., Holtman, N., Pool, H. \& Poppelaars, G. (Regie). (2004). Allemaal Theater. Van 1945 tot nu. [4-DVD's]. Amsterdam: VandenEnde Foundation/AVRO/IDTV-DITS/TIN.

Dixhoorn, M, van (2014, 17 oktober). Steeds meer acteurs worden freelancer. de Volkskrant, p. 7. 
Dixhoorn, M, van (2014, 17 oktober). Contracteren. de Volkskrant, p. V6-7.

Dixon, S. (2007). Digital Performance. A History of New Media in Theater, Dance, Performance Art, and Installation. Cambridge, MA: MIT Press.

Dodemont, H. (1998). Talent in stilte bloeyende. Ontwikkeling van het acteeronderwijs tussen 1960 en 1995 (doctoraalscriptie Universiteit van Amsterdam).

Amsterdam: Universiteit van Amsterdam.

Donker, J. (1996). De School voor Bewegingstheater geopend. Mime en bewegingstheater in Nederland. In Erenstein, R., Coigneau, D., Van Gaal, R., Peeters, F., Pleij, H., Porteman, K., et al. (red.), Een theatergeschiedenis der Nederlanden. Tien eeuwen drama en theater in Nederland en Vlaanderen (pp. 730-736). Amsterdam: Amsterdam University Press.

Dool, P. van den (2011, 3 september). Onderzoek NRC: brede steun voor kunstbeleid Zijlstra. NRC Handelsblad. Retrieved December 7, 2011, from http://www.nrc.nl/nieuws/2011/09/03/onderzoek-nrc-brede-steun-voorkunstbeleid-zijlstra/

Dooremalen, T. van (2001). Ketenstrategieën in de podiumkunsten (doctoraalscriptie Universiteit van Tilburg). Tilburg: Universiteit van Tilburg.

Doorman, M. (1994). Steeds mooier. Over vooruitgang in de kunst. Amsterdam: Uitgeverij Bert Bakker.

Dulken, H. van den (2002). Sanering van de subsidiëring. Overheidsbemoeienis met monumentenzorg, film en toneel vanaf de jaren zestig. Amsterdam:

Boekmanstudies.

Eggermont, P., Sonnen, A., Richter, D., Rosingh, K., \& Knebel, X. (red.). (2007). Blokboek, Blokschijf. Tom Blokdijk over theater, 1970-nu. Amsterdam: Theater Instituut Nederland.

Ende, I. van der (2012). Stellar Sound Show. The Story behind the performance. Maastricht: Toneelacademie Maastricht.

Eisenstein, S. M. (1981). Montage, het constructieprincipe in de kunst (W. Oranje, vert.). Nijmegen: SUN. (Oorspronkelijke uitgave tussen 1923/1946)

Epskamp, K. \& Schra, E. (2002). Richard Schechner en het theater in de 21e eeuw. In K. Epskamp \& E. Schra (red.), Interculturele puzzels. Utrecht: Passe-partout Publications.

Erp, J.B.F. van (2007). Tactile displays for navigation and orientation: perception and behavior (proefschrift Universiteit Utrecht). Utrecht: Utrecht University Press

Even-Zohar, I. (1978/2005). Polysystem Theory (Revised). In I. Even-Zohar, Papers in Culture Research. Retrieved May 28, 2013, from http://www.tau.ac.il/ itamarez/works/books/EZ-CR-2005_2010.pdf

Fischer-Lichte, E. (2004). Ästhetik des Performativen. Frankfurt am Main: Suhrkamp Verlag. 
Fischer-Lichte, E. (2008). The Transformative Power of Performance. A New Aesthetics.

(S. I. Jain, Trans.). London and New York: Routledge. (Original work published 2004)

Fischer, N. (2006). Uri Rapaport's kleine manifest voor het theater van de toekomst. In H. Havens, C. Kattenbelt, E. de Ruijter \& K. Vuyk (red.), Theater \& Technologie (pp. 229-237). Amsterdam: Theater Instituut Nederland.

Florida, R. (2002). The Rise of the Creative Class. New York: Basic Books.

Florida, R. (2005). The Flight of the Creative Class. New York: Harper Collins Publishers Inc.

Foucault, M. (2010). The Archaeology of Knowledge (A. Sheridan, Trans.). Oxford an New York: Routledge. (Original work published 1972)

Frissen, P. (2007a). Allemaal anders. Een lofzang op verschil en ongelijkheid. Rotterdam: Uitgeverij Godoy \& Godoy.

Frissen, P. (2007b). De Staat van verschil. Een kritiek van de gelijkheid. Amsterdam: Van Gennep.

Frissen, V. (2009). Digitalisering in het culturele domein: van e-cultuur naar zwart gat? In B. Heine, V. Frissen, F. Laroui, S. Selwood \& P. Schnabel (red.), Cultuur en Media in 2015. Amsterdam: Boekmanstudies.

Fuchs, E. (2008). [Review of H.T. Lehmann. Postdramatic Theatre (K. J. Jürs-Munby, Trans.). London and New York: Routledge (2006)]. The Drama Review, 52(2), 178-183.

Gallois, C. (2009). Een archipel van lokale reacties. Nicolas Bourriad over het altermoderne. Metropolis $M$, (1), 30-36.

Geertz, C. (1973). The Interpretation of Cultures. New York: Basic Books.

Géricault, T. (1818). Le Radeau de la Méduse [Schilderij]. Parijs: Louvre.

Gielen, P. (2003). Kunst in netwerken. Artistieke selecties in de hedendaagse dans en de beeldende kunst. Leuven: Lannoo Campus.

Gielen, P. (2011). Misschien wordt het tijd om te acteren. Over de naakte 'onmaat'. Etcetera. Tijdschrift voor podiumkunsten, 29(127), 3-8.

Gielen, P. (2012). Artistieke praxis en de neo-liberalisering van de onderwijsruimte. In H. Borgdorff, \& P. Sonderen (red.), Denken in de kunst. Theorie en reflectie in het kunstonderwijs (pp. 86 - 103). Leiden: Leiden University Press.

Gielen, P. (2013). Repressief Liberalisme. Opstellen over creatieve arbeid, politiek en kunst. Amsterdam: Valiz.

Goodman, N. (1976). Languages of art. An approach to a theory of symbols. Indianapolis/Cambridge: Hackett Publishing Company, Inc.

Goudsblom, J. (1990). Balans van de sociologie (3e dr.). Nijmegen: SUN. 
Gravas, R. (Director), M.I.A. and Switch (Production), Maya "M.I.A." Arulpragasam, Dave "Switch" Taylor, Alan Vega and Martin Rev (Writers and composers) (2010). Born Free [Music Video]. Retrieved January 18, 2013, from http://vimeo.com/11219730

Hajer, M. (1995). The Politics of Environmental Discourse: Ecological Modernization and the Policy Process. Oxford: Clarendon Press.

Hajer, M. (2000). Politiek als vormgeving (inaugurale rede Universiteit Amsterdam). Amsterdam: Amsterdam University Press.

Hall, S. (Ed.). (1997). Representation, Cultural Representations and Signifying Practices. London: SAGE Publications Ltd.

Hardt, M., \& Negri, A. (2004). Multitude, War and Democracy in The Age of Empire. New York: The Penguin Press.

Havens, H. (1991). Het gaat niet om smaak maar om begrip. Toneel Theatraal, 112(9), 42-43.

Havens, H., \& Dujardin, M. (1998). Gesubsidieerd toneel behoeft speelruimte. Boekmancahier, 10(38), 357-364.

Havens, H., \& Mineur, F. (1999). Alles ist schon da! Theatermaker, 119(5), 30-32.

Havens, H. (2004). Interdisciplinariteit en technologie. In C. Kattenbelt, P. de Kort \& D. Mesker (red.), Zoekboek 1 (pp.88-93). Maastricht: Hogeschool Zuyd.

Havens, H. (2006). Van Eboman tot technolab, technologie en vernieuwingen in het theateronderwijs. In H. Havens, C. Kattenbelt, E. de Ruijter \& K. Vuyk (red.), Theater \& Technologie (pp. 78-91). Amsterdam: Theater Instituut Nederland.

Havens, H., Kattenbelt, C., Ruijter, E. de, \& Vuyk, K. (red.) (2006). Theater \& technologie. Amsterdam: Theater Instituut Nederland.

Havens, H. (2009). Zwischen Technolab und Bühnen-Rampe. Theater der Zeit/Double. 11-2009, 8-11.

Havens, H. (2010). The Intermedial Performer Prepares. In S. Bay-Cheng, C. Kattenbelt, A. Lavender \& R. Nelson (Ed.), Mapping Intermediality in Performance (pp. 230236). Amsterdam: Amsterdam University Press.

Heide, A. van der (regisseur), Tabbers, L. (scenario), \& Eyeworks (producent) (2007). MissiePoo16 [Speelfilm]. Nederland: Eyeworks

Heinink, S. (1994). Licht aan! Discussie. 'Aktie Tomaat' of de geschiedenis van een bewustwording. In D. Meyer (red.), Tomaat in perspectief.

Theatervernieuwingen in de jaren '60 en '70 (pp. 7-23). Amsterdam: Theater Instituut Nederland.

Hoekstra, T., et al. (1919). De studie van de 'volksziel, noodig voor ambtelijken arbeid. Gereformeerd Theologisch Tijdschrift. Retrieved October 12, 2011, from http://www.neocalvinisme.nl/dv/jw/jwgtt190910.html 
Hoeven, Q. van der (2005). De grens als spiegel. Een vergelijking van het cultuurbestel in Nederland en Vlaanderen. Den Haag: Sociaal Cultureel Planbureau.

Hoeven, Q. van der (2012). Van Anciaux tot Zijlstra. Cultuurbeleid en cultuurparticipatie in Nederland en Vlaanderen. Den Haag: Sociaal Cultureel Planbureau.

Horst, A. van der, \& Zoutman, R. (2010). Verschil maken, een terugblik. Evaluatie subsidiesystematiek OCW. Amsterdam: DSP-groep.

Hospers, G.J., \& Timmerman, P. (2001). De metamorfose van het Ruhrgebied. Geografie, 10(2), 41-43.

Idema, J., \& Grievink, H.J. (2007). Datascape Cultuur. Amsterdam: LA Group.

Jans, E. (2006a). Interculturele intoxicaties. Over kunst, cultuur en verschil. Berchem: Uitgeverij EPO.

Janssen, H. (2008, 29 mei). Molière is voor mij een dodendans. de Volkskrant. Retrieved October 3, 2014, from http://www.volkskrant.nl/recensies/moliereis-voor-mij-een-dodendans a912317/

Janssen, S. (2005). Het soortelijke gewicht van kunst in een open samenleving. De classificatie van cultuuruitingen in Nederland en andere landen na 1950 (Inaugurale rede Erasmus Universiteit Rotterdam). Rotterdam: Erasmus Universiteit Rotterdam.

Jauss, H. R. (1982). Towards an Aesthetic of Reception. (T. Bahti, Trans.). Brighton: The Harvester Press Limited.

Jong, M. de (2014). Festivals weer in de lift door aanboren nichemarkt. Retrieved August 1, 2014, from http://www.nu.nl/weekend/3842650/festivals-weer-inlift-aanboren-nichemarkt.html

Kammer, C., \& Van Lent, D. (2014, 15 mei). Theaters: bouwen ondanks crisis. NRC Handelsblad, p. C3.

Kattenbelt, C. (2006). Theatre as the Art of the Performer and the Stage of Intermediality. In F. Chapple \& C. Kattenbelt (Eds.), Intermediality in Theatre and Performance (pp. 29-39). Amsterdam and New York: Rodopi.

Kattenbelt, C. (2010). Intermediality in Performance and as a Mode of Performativity. In S. Bay-Cheng, C. Kattenbelt, A. Lavender \& R. Nelson (Eds.), Mapping Intermediality in Performance (pp. 27-37). Amsterdam: Amsterdam University Press.

Kerkhoven, M. van (1992). Aan de onverschilligheid voorbij. Theaterschrift 1(1), 1-33. Kerkhoven, M. Van (2002). Niet meer spelen, maar gespeeld worden. Bedenkingen omtrent het acteren vandaag. In M. van Kerkhoven, Van het kijken en van het schrijven. Teksten over theater (pp. 81-94). Leuven: Uitgeverij Van Halewyck. (Oorspronkelijke uitgave 1991) 
Kerkhoven, M. van (2007). Guy Cassiers (Electronic Version). Kaaitheater Bulletin.

Retrieved January 4, 2013, from

http://www.kaaitheater.be/page.jsp?id=212\&lang=nl

Keulemans, C, Nekuee, S., \& Top, B. (2004). Een staalkaart van hybride theater. In R.

Buikema \& M. Meijer (red.), Kunsten in Beweging, Cultuur en migratie in

Nederland Deel II 1980-2000 (pp. 365-380). Den Haag: Sdu Uitgevers.

Kleinout, G. W. H. (2006). Jazz als probleem. Receptie en acceptatie van de jazz in de wederopbouwperiode van 1945 - 1952. Utrecht: Universiteit Utrecht.

Klinkenberg, R. (2005). Drie kluiten op een hondje, klein lexicon van het theater. Amsterdam: Uitgeverij International Theatre \& Film Books.

Konijn, E. (1994). Acteurs spelen emoties. Vorm geven aan emoties op het toneel. Amsterdam: Boom.

Kouters, V. (2014, 17 februari). Wonderbaarlijke schizo-solo. de Volkskrant, p. V6

Kraak, H. (2014, 6 oktober) De jacht op jong techtalent is geopend. de Volkskrant, Media.

Krans, A. (2005). Vertraagd Effect. Hedendaags theater in 1 inleiding en 18 interviews. Amsterdam: Theater Instituut Nederland.

Kuhn, T. (2003). De structuur van wetenschappelijke revoluties (B. Willink, vert.). Amsterdam: Uitgeverij Boom. (Oorspronkelijke uitgave 1962)

Kuyper, E. de, Cassiers, G., Jans, E. (red.). (2003). Op zoek naar de verloren tijd. Proust 1: De kant van Swann, script \& werkboek. Amsterdam: Uitgeverij International Theatre \& Film Books.

Kuypers, P. (2005). Agenda voor het denken over theater. In P. Eggermont, I. van Hamersveld, P. Kuypers, C. Smithuijsen, M. van Steen \& K. Vuyk (red.), Theater moet schuren. Essays over de maatschappelijke opdracht van het theater (pp. 15-32). Amsterdam: Boekmanstudies.

Laere, K. van (regisseur-ontwerper), Laere \&Toneelacademie Maastricht (producenten). (2009). Peak Oil [fashion performance]. Maastricht: Toneelacademie. Retrieved May 29, 2013, from www.YouTube.com/watch?v=ZCpyF7ZEPnl

Latour, B. (1990). Postmodern? No, simply amodern! Steps towards an anthropology of science. Studies of history and philosophy of science, Volume 21, 145-171.

Latour, B. (1993). We have never been modern (C. Porter, Trans.). Cambridge: Harvard University Press. (Oorspronkelijke uitgave 1991).

Latour, B. (1999). On recalling ANT. In J. Law \& J. Hassard (Eds.), Actor Network Theory and after (pp. 15-25). Oxford: Blackwell Publishers.

Latour, B. (2005). Reassembling the Social. An Introduction to Actor-Network-Theory. Oxford and New York: Oxford University Press.

Latour, B. (2008). What is the Style of Matters of Concern? Assen: Van Gorcum. 
Law, J., \& Hassard, J. (Eds.). (1999). Actor Network Theory and After. Oxford: Blackwell Publishers.

Law, J. (2007). Actor Network Theory and Material Semiotics. Retrieved May 28, 2013, from

http://heterogeneities.net/publications/Law2007ANTandMaterialSemiotics.pdf

Lehmann, H.T. (1997). From Logos to Landscape: Text in Contemporary Dramaturgy. Performance Research 2.1 (pp. 55-60).

Lehmann, H.T. (2011) Van Logos naar landschap: tekst in hedendaagse dramaturgie (I. Goerlandt, vertaling uit het Engels). In C. Swyzen \& K. Vanhoutte (red.), Het Statuut van de tekst in het post-dramatisch theater (pp. 27-37). Antwerpen: University Press Antwerpen. (Oorspronkelijke uitgave 1997)

Lehmann, H.T. (1999). Postdramatisches Theater. Frankfurt am Main: Verlag der Autoren.

Lehmann, H.T. (2006). Postdramatic Theatre (K. J. Jürs-Munby, Trans.). London and New York: Routledge. (Original work published 1999)

Lent, D. van (2013, 4 januari). Het doek valt voor de vaste acteur. NRC Handelsblad, p. C22.

Ligthart, P. (1988). Toneelbeleid in Nederland, subsidiering en advisering vanaf 1950. Amsterdam: Boekmanstichting.

Linden, A. van der (2007). Dialoog? Het discours rondom de cultuurnota systematiek in kaart gebracht (masterscriptie Universiteit Utrecht). Utrecht: Universiteit Utrecht.

Maanen, H. van (1997). Het Nederlandse Toneelbestel van 1945 tot 1995. Amsterdam: Amsterdam University Press.

Maanen, H. van (2001). Van podia naar dépodia. In R. Engelander (red.), Theater als systeem (pp. 23-40). Amsterdam: Theater Instituut Nederland.

Maanen, H. van (2008). A world of independents in the Dutch theatre system. In I. van Hamersveld \& C. Smithuijsen (Eds.), State on Stage. The impact of public policies on the performing arts in Europe (pp. 122-138). Amsterdam: Boekmanstichting.

Maanen, H. van (2009). How to study Art Worlds. On the Societal Functioning of Aesthetic Values. Amsterdam: Amsterdam University Press.

Manovich, L. (2001). The Language of New Media. Cambridge MA: MIT Press.

McKenzie, J. (2001). Perform or else: from discipline to performance. Londen \& New York: Routledge.

Meijer, M. (1988). De lust tot lezen. Nederlandse dichteressen en het literaire systeem. Amsterdam: Van Gennep/Sara.

Meijer, M. (1996). In tekst gevat. Inleiding tot een kritiek van representatie. Amsterdam: Amsterdam University Press. 
Merx, S. (2006). Verdubbeling en transformatie. De rol van video in de Proustcyclus van Guy Cassiers. In H. Havens, C. Kattenbelt, E. de Ruijter \& K. Vuyk (red.), Theater \& Technologie (pp. 48-61). Amsterdam: Theater Instituut Nederland.

Merx, S. (2009). Beelden van tijd. Op zoek naar de tijdsdramaturgie in de 'Proustcyclus' van Guy Cassiers (proefschrift Universiteit Utrecht). Utrecht: Universiteit Utrecht.

Metz, T. (2010, 19 februari). Een groggy jongetje en een bijtende baby. NRC Handelsblad, p. K09.

Meyer, D. (red.). (1994). Tomaat in perspectief. Theatervernieuwing in de jaren '60 en '70. Amsterdam: Theater Instituut Nederland.

Mijndelts, W. (2008, 8 februari). Is het een roman? Is het een film? Nee, het is een strip! NRC Handelsblad, p. B10.

Mik, A. (2000). Primal gestures, minor roles. Rotterdam: Nai Uitgevers.

Mik, A. (2002). Echt Onecht, over de verhouding tussen de realiteit van zijn werk en beelden uit de realiteit en de media. Enschede: Heineken Lecture, Universiteit Twente. Retrieved May 12, 2011, from

http://www.google.nl/url?sa=t\&rct=j\&q=\&esrc=s\&source=web\&cd=3\&ved=0CC wQFjAC\&url=http\%3A\%2F\%2Fwww.knaw.nl\%2Fen\%2Fnews\%2Fpublications\%2 Fheineken-lectures-

2002\%2F\%40\%40download\%2Fpdf_file\%2F20021146.pdf\&ei=ZokOVe2JGobjaK nlgoAC\&usg=AFQjCNHHV3mUIwnRwB5SHJwD64yZu5m1vA\&bvm=bv. 88528373 ,d.d2s

Mills, S. (1997). Discourse. London: Routledge.

Missotten, P. (2014). Intermedialiteit. Maastricht: Toneelacademie Maastricht.

Mostert, G. (2011). Marga Klompé 1912-1986. Een biografie. Amsterdam: Uitgeverij Boom.

Mul, J. de (2002). Cyberspace Odyssee. Kampen: Uitgeverij Klement.

Munster, O. van (1995). De Podiumkunsten na 2000, naar een nieuw beleid. Utrecht: Berenschot Groep BV

Nederveen Pieterse, J. (2004). Globalization \& Culture: Global Mélange. Lanham (US) and Oxford (UK): Rowman \& Littlefield Publishers.

Nelson, R. (2013). Practice as Research in the Arts. Principles, Protocols, Pedagogies, Resistances. London and New York: Palgrave Macmillan

Netwerk voor vrouwelijke theatermakers. (2000). Hee! Een Pamflet. Amsterdam: Auteur.

Nooren, M. (2006). It's Time To Meet The Real You. Het hedendaagse discours over maatschappelijk engagement binnen het Nederlandse theater in kaart gebracht (masterscriptie Universiteit Utrecht) Utrecht: Universiteit Utrecht. 
Ogden, D. (1987). Performance dynamics and the Amsterdam Werkteater. Berkeley: University of California Press.

Oosterbaan Martinius, W. (1990). Schoonheid, Welzijn, Kwaliteit. Kunstbeleid en verantwoording na 1945. 's-Gravenhage: Sdu.

Oosterbaan Martinius, W. (2011, 1 juli). Waarom nog geld voor de kunsten? de Volkskrant, p. V12-13.

Oostveldt, B. van (2014). Neem een voorbeeld aan Anne Teresa De Keersmaeker. Theatermaker, 18(6), 30-31.

Parker, A. \& Kosofsky-Sedgwick, E. (Eds.). (1995). Performativity and Performance. New York and London: Routledge.

Paumen, M. (2000). Toneel, toneel, altijd toneel. Maastricht: Toneelacademie Maastricht.

Peters, P.F. (2006). Time, Innovation and Mobilities. Travel in technological cultures. London: Routledge.

Peters, P.F. (2009). Grensverkeer. Over praktijkonderzoek voor de kunsten (inaugurale rede Zuyd Hogeschool). Maastricht: Zuyd Hogeschool.

Petty, A. (Director), Beyoncé Knowles, Shea Taylor, Cainon Lamb (Producers), Terius Nash, Shea Taylor, Knowles, Ester Dean, Cainon Lamb, Julie Frost, Michael Bivins, Nathan Morris \& Wanya Morris (Writers). (2011). Countdown [Music Video]. Retrieved December 27, 2012, from http://www.YouTube.com/watch?v=PDT0m514TMw

Pisters, P. (2009). Micropolitiek In E. Romein, M. Schuilenburg, S. van Tuinen (red.), Deleuze Compendium (pp. 224-236). Amsterdam: Uitgeverij Boom.

Pots. R. (2002). Cultuur, koningen en democraten: overheid \& cultuur in Nederland. Nijmegen: SUN.

Prensky, M. (2001). Digital Natives, Digital Immigrants. On the Horizon, 9(5). Retrieved June 15, 2012, from http://www.marcprensky.com/writing/Prensky\%20\%20Digital\%20Natives,\%20Digital\%20Immigrants\%20-\%20Part1.pdf

Raessens, J. (2001). Cinema and beyond. Film en het proces van digitalisering. uvt.nl, Eview 01(1). Retrieved September 16, 2008, from http://comcom.uvt.nl/eview/01-1/raes.htm

Raessens, J. (2012). Picasso maakt nu games. NEWMEDIAstudies. Retrieved Oktober 25, 2012, from http://www.newmediastudies.nl/magazine/picasso-maakt-nugames

Rahmani, M. (2014). Representatie van noord Afrikaanse en midden Oosterse allochtonen in de Nederlandse populaire film tussen 2001 en 2014. Maastricht: Toneelacademie Maastricht.

Rancière, J. (2010). De toekomst van het beeld (W. van der Star, vert.). Amsterdam: Octavo publicaties. 
Rajewski, I. (2005). Intermediality, Intertextuality, and Remediation: A Literary

Perspective on Intermediality. Retrieved December 22, 2014 from

http://cri.histart.umontreal.ca/cri/fr/intermedialites/p6/pdfs/p6_rajews

ky_text.pdf

Rajewski, I. (2010). Border Talks: The Problematic Status of Media Borders in the

Current Debate about Intermediality. In L. Elleström (Ed.), Media Borders,

Multimodality and Intermediality (pp. 51-68). London \& New York: Palgrave

Macmillan.

Romanek, M. (Director) \& Red Hot Chili Peppers (Composers, Performers). (2002).

Can't stop [Music Video]. Retrieved December 27, 2012, from

http://vimeo.com/27948543

Romein, E., Schuilenburg, M., \& Tuinen, S. van (red.). (2009). Deleuze Compendium.

Amsterdam: Uitgeverij Boom.

Salter, C. (2010). Entangled. Technology and the Transformation of Performance.

Cambridge MA: The MIT Press.

Schaap, W. (2008). Het Antwerps Model. Theatermaker, tijdschrift over theater, muziek \& dans, 12(1), 33-45.

Schayk, M. Van (2001). Hallo Medemens. Geschiedenis van Het Werkteater.

Amsterdam: Theater Instituut Nederland.

Schechner, R. (1992). A New Paradigm for Theatre in the Academy. The Drama Review, 36(4), 7-10.

Schechner, R. (2000). Theatre Alive in the New Millennium. The Drama Review, 44(1), 5-6.

Schechner, R. (2002a). Is er nog behoefte aan theater in de 21e eeuw? In K.Epskamp en E. Schra (red.), Interculturele puzzels, Richard Schechner en het theater in de 21e eeuw. Utrecht.

Schechner, R. (2002b). Performance Studies. An introduction. London and New York: Routledge.

Scheffer, P. (2000, 29 januari). Het multiculturele drama. NRC Handelsblad. Retrieved February 5, 2009, from http://retro.nrc.nl/W2/Lab/Multicultureel/scheffer.html

Scheffer, P. (2007). Het Land van aankomst. Amsterdam: Uitgeverij De Bezige Bij.

Schinkel, W. (2008). De gedroomde samenleving. Kampen: Uitgeverij Klement.

Schnabel, P. (2009). Continu Onderzoek Burgerperspectieven. Een periodiek onderzoeksverslag van het Nederlandse SCP. Den Haag: Sociaal Cultureel Planbureau.

Schön, D. A. (1983). The Reflective Practitioner: How Professionals Think in Action. Aldershot: Ashgate Publishing Limited.

Schwartz, M. (1999). Digitale media in de technologische cultuur. Perspectieven voor een kunst- en cultuurbeleid. Den Haag: Sdu. 
Seale, C. (Ed.). (1998). Researching Society and Culture. London: SAGE Publications.

Sennett, R. (2008). De ambachtsman. De mens als maker (W. van Paasen, vert.).

Amsterdam: Meulenhoff. (Oorspronkelijke uitgave 2008)

Sloterdijk, P. (2006). Het Kristalpaleis (H. Driessen, vert.). Amsterdam: Uitgeverij Boom/SUN. (Oorspronkelijke uitgave 2005).

Sloterdijk, P. (2009). Sferen III: Schuim, plurale sferologie (vert. H. Driessen).

Amsterdam: Uitgeverij Boom. (Oorspronkelijke uitgave 2004)

Sonnen, A. (2008). Een voorstelling uit het hiernamaals. In E. Jans (red.), Toneelg(e)ruis, $3(3), 98-102$.

Spel, M., \& Wensink, H. (2015, 8 januari). 'Kunst helpt ons om de wereld beter te begrijpen'. NRC Handelsblad, C8.

Staay, A.J. Van der. (1970). In W. Zweers,W \& L.A. Welters Toneel en publiek in Nederland. Rotterdam a.o.: Universitaire Pers Rotterdam a.o.

Sterling, B. (2012). An Essay on the New Aesthetic. WIRED Magazine. Retrieved March 10, 2013, from http://www.wired.com

Stigter, B. (2009, 20 maart). Surrealisme van de straat. NRC Handelsblad, p. C06.

Swaan, A. de (2008). De draagbare De Swaan. Amsterdam: Uitgeverij Bert Bakker.

Swyzen, C., \& Vanhoutte, K. (red.). (2011). Het Statuut van de tekst in het postdramatische theater. Antwerpen: University Press Antwerpen.

Szondi, P. (1956). Theorie des modernen Dramas (proefschrift Universität Zürich). Frankfurt am Main: Suhrkamp Verlag.

Takken, W. (2009, 6 maart). De typecasting ontstegen. Allochtone acteurs in de rol van Fons en Ank. NRC Handelsblad, p. C06.

Tarkovski, A. (regisseur) \& Demidova, A. (producent) (1979). Stalker [speelfilm]. Moskou: MOSFILM.

Tarkovski, A. (2007). De Verzegelde Tijd (A. Uijterlinde, vert.). Groningen: Historische Uitgeverij. (Oorspronkelijke uitgave 1984)

Theater Heute (2008). Speciaal nummer: Die süssen Versprechen der Postdramatik Was kommt nach der Postdramatik? Oktober 2008, 7-19.

Toneelgroep Amsterdam, (1987). Plannen en dromen; Waarom...daarom. Amsterdam: Auteur.

Tonkiss, F. (2006). Analyzing text and speech: content and discourse analysis. In C. Seale (Ed.), Researching Society and Culture (pp. 367-382). London: SAGE Publications Ltd. (Original work published 1998).

Trienekens, S. (2009). Kunst in het hart van de samenleving. Over burgerschap en culturele dynamiek. Amsterdam: Hogeschool van Amsterdam Publicaties. 
Tuinen, S. van, Schuilenburg, M., \& Romein, E. (2009). Qu'est-ce que la Philosophie? De voorwaarden van het denken volgens Deleuze \& Guattari. In E. Romein, M. Schuilenburg \& S. van Tuinen (red.), Deleuze Compendium (pp. 21-45). Amsterdam: Uitgeverij Boom.

Turner, J.M.T. (1844). Rain, Steam and Speed [Schilderij]. Londen: National Gallery. Van Dale Groot woordenboek der Nederlandse taal (1999). Utrecht: Van Dale Lexicografie.

Vanderbroeck, D. (2012). The Shrinkwrap Adventure. How Theatre becomes Fashion. Maastricht: Toneelacademie Maastricht.

Vinkenburg, B. (2010). Kunst \& Cultuur, het investeren waard? Utrecht: Bureau Berenschot.

Vuyk, K. (1987). Een nieuwe theatrale omgang met tekst. Speciaal nummer: Nederlands Theaterjaarboek 1986-1987. Toneel Theatraal 36, 10-12.

Vuyk, K. (2003). Na de omkering. TM, 7(5), 38-40.

Walraven, E. (2007). Chachacha van praktijk en beleid. In P. Eggermont, A. Sonnen, D. Richter, K. Rosing \& X. Knebel (red.), Blokboek, Blokschijf. Tom Blokdijk over theater, 1970-nu (pp. 93-109). Amsterdam: Theater Instituut Nederland.

Wals, A. (2012, 14 september). Den Haag bouwt nieuw theater. de Volkskrant. Retrieved May 28, 2013, from http://www.volkskrant.nl/vk/nl/2844/Archief/archief/article/detail/3316190/2 012/09/14/Den-Haag-bouwt-nieuw-theater.dhtml

Williams, R. (2002). Culture is ordinary. In B. Highmore (Ed.), The Everyday Life Reader (pp. 91-100). London and New York: Routledge. (Original work published 1958). Williams, R. (1977). Marxism and Literature. Oxford: Oxford University Press.

Winterson, J. (2007). De beker, het mes, de jas en de remedie (R. Fagel, vert.). Retrieved May 28, 2013, from Retrieved May 28, 2013, from http://home.versatel.nl/peter.vanpelt/Wintersonlezing.htm

Wittgenstein, L. (2002). Filosofische onderzoekingen (M. Derksen \& S. Terwee, vert.). Amsterdam: Uitgeverij Boom. (Oorspronkelijke uitgave 1953)

Woudenberg, H. (1999). Vuur, water, lucht, aarde. Amsterdam: International Theatre \& Film Books.

Zweers, J., \& L.A. Welters, (1970). Toneel en publiek in Nederland. Rotterdam a.o.: Universitaire Pers Rotterdam a.o.

Zwietink, O. (2000). Lang meegaan. Maastrichtse methode voor spraaktraining van acteurs. Maastricht: Toneelacademie Maastricht. 


\section{Summary}

\section{Crisis or repositioning?}

This study started in 2007 as the result of a fascination for the theatre discourse in the early 21st century. This discourse is in many ways a Gordian knot; a supposed theatre crisis, an internationally leading Dutch performing arts sector and the emergence of new platforms, new production methods and a new audience for innovative performative expression in the broader cultural context of the Dutch theatre establishment. With the latter I'm referring to the system that since 1945 has revolved around four institutional actors: theatre companies, performance venues, theatre schools and the national political theatre policy. This system forms part of a political strategy of cultural uplifting and has remained more or less unchanged in the last seventy years while fundamental developments in its social and cultural context have taken place. This research investigates how the current system relates to the dynamics of its transformed context.

\section{Practice as Research}

The central question of this research project is: to what extent does contemporary theatre reflect current cultural dynamics characterized by technological, intercultural and globalizing progress and in which ways does theatre contribute to these dynamics? This research project belongs to the discipline of theatre studies. It is meant to be a contribution to the discourse on postdramatic theatre - a term coined by Hans-Thies Lehmann in his work Postdramatisches Theater (Lehmann, 1999) - and central elements from the discourse that followed it, for example in the works of Erika FischerLichte (Fischer-Lichte, 2008). This study offers four case studies on the functioning of the institutional actors mentioned above, using a theoretical framework based on three network theories: Even-Zohar's Polysystem Theory, Gilles Deleuze's Rhizome theory and Bruno Latour's Actor Network Theory.

Because of my own position as a teacher at a theatre school that is also object of this study, my research can be seen as practice based, carried out from within the theatre school as research context. For the methodological implications of this approach, becoming more familiar under the name Practice as Research (PaR), I refer 
primarily to Robin Nelson's recent publication Practice as Research in the Arts. Principles, Protocols, Pedagogies, Resistances (Nelson, 2013).

The objects of my case studies were the Flemish theatre company Toneelhuis in Antwerp; the multidisciplinary venue the Verkadefabriek in 's Hertogenbosch, the Maastricht Theatre Academy and the Dutch theatre policy between 1945 and 2014. For the theatre company the empirical material consisted of a series of interviews with employees and publications surrounding annual planning and performances, for the case study on the venue interviews were conducted as well, alongside participating observation of playbill items over a long period of time. As mentioned, the research method used to examine the functioning of the theatre school can be called practice as research, stemming from my position as a theatre teacher myself, and lastly the research on the Dutch theatre policy consisted mostly of literary sources as well as participating observation.

\section{Findings in the case studies}

At the Toneelhuis Antwerp, remodeled in 2006 by Guy Cassiers, we can see that the outlines, construction and operation do not correspond any longer with what is traditionally regarded a major subsidized theatre company. The repertoire is more differentiated than - conventionally - works based on the drama-literary canon, resulting in changes in the structure, organization and production methods of the company. One important change is the dramaturgical influence of technology, playing an important thematic, design-technical role in the company's pieces, not just auxiliary but artistically constituent. This has brought about an emancipation of the theatre technician among other things. Furthermore the transformation from a fixed ensemble of actors to a rhizomatic association of performance artists acknowledges the increasing relevance of intermedial, intercultural and international developments.

The Verkadefabriek quickly became one of the major intercultural venues for 'sHertogenbosch and its far surroundings. The building and the organization 'perform' the coming together of different cultures so to speak. The venue functions as mediator, as a junction point facilitating dialogues and alliances among different cultures. The growing diversity of this type of venues problematizes the traditional function of theatre venues as intermediaries, committed to the keeping alive of canonical theatre, to which they still primarily owe their status. In a cultural constellation that has fundamentally changed, it is considerably harder for traditional theatre venues to develop new audience strategies than it is for relatively new types of venues - physical or virtual.

The changes contemporary theatre has undergone towards a multilayered theatre-, performance- and media landscape have far-reaching consequences for a theatre school like the Maastricht Theatre Academy. Due to a blurring of boundaries between 
the professions of actor, director, media artist and performer, theatrical expertise is morphing more and more into different types of performative expertise. Along with the education of theatre professionals, the positioning of the academy in the theatre landscape changes as well. Once primarily facilitating the established theatre practice, it has become co-constituent of the actual performative practice. The relation between the Maastricht Theatre Academy and the professional theatre practice shows a shift from a focus on Dutch subsidized theatre to a more international, hybrid theatre-, performance- and media practice. This results among other things in an increasingly international, diverse student community at the academy.

The case study on the Dutch theatre policy has lead to the view that theatre policy between 1945 and 2015 was mostly dictated by the political situation at any given time. In the seventies and the nineties social relevance, experiment and diversity was called for. In the early eighties more traditional values gained ground and since 2010 the severe subsidy budget cuts are the sector's main concern. Especially subsidies for experiment, talent development and artistic research were diminished and the policy became focused on the established theatre companies, market forces and cultural entrepreneurship. In the discursive relation between governmental cultural policy, the theatre sector and society, the former loses its binding with increasingly relevant cultural and social contexts at the risk of becoming residual, belonging to the cultural rearguard. Society regards the performative as broader than theatre alone, and has a different relation to the totality of the performative spectrum than the government has. The ongoing emancipation of popular culture has had little effect on the arrangement, positions and working methods of the major actors in the discourse on theatre policy. The heavy focus on market forces and the supposed instant salability of good art that characterizes the current Dutch cultural subsidy policy has led to an undervaluation of the cultural and social relevance of extra-territorial forms of art and culture and the potential social and cultural importance of changing performative practices and their relation to new cultural and artistic frameworks.

\section{Beyond Lehmann's theatre aesthetics}

In his seminal work Postdramatisches Theater (Lehmann, 1999), Hans-Thies Lehmann mapped the developments in theatre between 1970 and 1999. His term postdramatic theatre implied that western theatre at the turn of the 21st century had moved beyond traditional dramatic dimensions. Lehmann described a differentiation of the western theatre repertoire, a de-hierarchizing of theatrical practice and an increase of intermedial production technique. How should we evaluate the outcome of the case studies in this light?

We can see that the intermedial has grown increasingly important in a theatrical performance practice that has become more and more interdisciplinary, intercultural 
and international. Lehmann's notes on postdramatic theatre and the discourse that followed concerning the dichotomies word-image, theatre-performance, theatremedia and meaning-experience can be extrapolated to the overlapping border zones (Peters, 2009) between theatre and other art forms, as well as to bordering domains of culture and knowledge. Lehmann could not foresee the global rise of a digital network society and its professional and thematic consequences. He predominantly placed most transformations he identified within theatre as a separate art domain. Fifteen years later this conception of a framed, separate domain of theatre has become a niche in the vastly expanded hybrid realm of the performative spectrum. The results of my case studies show that the developments in this spectrum are no longer confined to the aesthetical categories of the art form theatre but extend into the management and operations of institutions as well, and so into the theatre system in its totality. What Lehmann called performance text - the total situation of a performance -, nowadays extends way beyond the established notions of theater and characterizes the form, organization and working of all institutions operating in the realm of the performative.

It should be noted that neither Lehmann nor Fischer-Lichte paid attention to the co-constituent role of theatre education and governmental theatre policy. I chose to do exactly that. From my research in the form of the four case studies the conclusion can be drawn that at least three of those four theatre institutions have undergone transformations in the last fifteen years that can be regarded as a continuation and widening of what Lehmann coined postdramatic theatre in 1999. This research shows that the incorporation of postdramatic transformations was not confined to purely artistic processes, but penetrated the practical operating procedures and organizational structures of the institutions as well; the software (theatre aesthetics) eventually also changed the hardware (theatre companies, venues, schooling). In the case study concerning governmental theatre policy, the transformation pattern is less univocal than in the other cases. The discourse on theatre policy shows colored dialectic by the constitution of successive governments. The rhizomatic connections between different art disciplines (Deleuze) and the polysystematic interaction between centre and periphery (Even-Zohar, 2005) only affect the theatre policy sporadically and by no means systematically. At the level of the theatre system as a whole, the government rarely looks beyond the established theatre infrastructure whose function is primarily to conserve cultural heritage, while a growing part of the audience turns away from subsidized theatre, increasingly engaging in and relating to the full width of the hybrid performative spectrum. One can say that the government still has not found a way to cope with the emancipation of less traditional and more popular forms of performative expression, putting pressure on the obviousness and justification of subsidies going to established traditional theatre. 


\section{Discussions and recommendations}

In what ways can the results of this research come in useful in the theatre practice of the near future? In spite of theatre companies like Toneelhuis Antwerp, who try to relate to a changing cultural context, a significant part of the institutionalized companies do not yet consider it of vital strategic importance to establish artistic connections on the spectrum outside the traditional theatre sector. Based on the research results, it would be advisable for theatre companies to engage in, for example, co-producing films, supplying actors, dramaturges or designers for (inter-) national TV series or contribute to the research and development of screenplays. Paired with relevant research programs from lectorates or technical universities, theatre companies could take part in practice-based research into immersive media, gaming or the application of 3D technology. In these possible collaborations the expansion of intermedial and intercultural knowledge and understanding should carry more weight than the production of theatre plays tout court.

Platforms like film, catwalk, television, social media, festivals, dance events, community art stages and hybrid podiums such as the Verkadefabriek have become normal stages but are still formally not valued as potential professional allies by the established parties involved (theatre companies and -schools, government, umbrella organizations). In light of this, recalibration of the role of influential traditional sector organizations such as the Association of Theatre venue- and Concert hall Directors is necessary. At the same time, discussions on prestigious new theatre venues should not be fixated on prices of land, revenue models and city branding, but more on the changing times, changing human behavior and the social role of art.

Contemporary theatre schools should make sure their students are taught a media-critical stance on their own sector, the cultural context and society in a broader sense. Alongside the widening of their students' professional future perspective, theatre schools in the Ba-Ma system have a role to play as allies in research into new art forms and the social relevance of the multitude of producers and stages on the performative spectrum.

For a restoration of the relation between the theatre sector, the government and society three changes are necessary in the governmental theatre policy. Only by developing a broader vision on the experience of art and culture can the government do justice to the social relevance of the full performative spectrum. Secondly, new policy tools will have to be developed; subsidy for new art forms is no longer in the same way necessary as with the more traditional art domains. Finally, in the new cultural policy discourse the government should actively seek and involve other partners than solely the established, canonical art institutions. One could think of a government that dares to assign research projects to different actors on the performative spectrum, comparable to what former Dutch minister of cultural affairs, 
Marga Klompé, did in the early seventies by raising the question: what type of theatre do our times ask for? It should nowadays also be the cultural political responsibility of the government to engage in and facilitate the exploration of the complex relations between popular culture and the traditional canonical theatre sector.

The case studies have led me to conclude that 'Theatre' as a delimited cultural sector has ceased to exist and rather became a subculture within a spectrum of performative subcultures. The performative spectrum has taken over the critical and reflective task that once was exercised by the traditional theatre sector. Because of its hybrid cultural versatility this network has a potentially far greater reach than theatre as stand-alone discipline ever had. To move along with such a perspective and explore its potential, it is necessary for theatre institutions to readjust their views: from being driven by unquestioned premises towards a researching curiosity for contemporary developments. It is by no means a matter of exchanging the canonical theatre tradition for anything new, but of nurturing the ambition to define points of contact between established theatre and the rest of the performative spectrum. It is the recurring matter of daring to fundamentally question the possible ways in which theatreperformance- and media art can be essential in our contemporary and future society. 


\section{Valorisatie-addendum}

\section{Maatschappelijke relevantie}

Met dit onderzoek wil ik een bijdrage leveren aan het theaterdiscours, dat vorm krijgt in het spanningsveld tussen de samenleving, de verschillende partijen die samen de gevestigde theatersector vormen, en de Nederlandse overheden (rijk, provincie en gemeenten). Ik heb een licht willen werpen op grootschalige veranderingen in en rond de theatersector, die ik meer beschouw als het gevolg van een intrinsiek veranderende samenleving dan van de recente bezuinigingsrondes door de overheid. Mijn onderzoeksresultaten kunnen een bijdrage leveren aan het genuanceerd duiden van de samenhang tussen grote recente culturele verschuivingen: de herpositionering van kunst en cultuur in het algemeen en theater in het bijzonder; de exponentiele toename van de omvang en het belang van tot nu toe nauwelijks serieus genomen en voor een groot deel nieuwe performatieve culturele sectoren; de maatschappelijke en culturele reuring die ontstond over het maatschappelijk draagvlak voor de gesubsidieerde kunstensector na de verkiezingen van juni 2010.

Met dit onderzoek hoop ik bij te dragen aan het ontzenuwen van het denken in culturele vijandbeelden, aan het ontmantelen van het denken in zij en wij, als het gaat om de relatie tussen gevestigde geïnstitutionaliseerde cultuursegmenten en minder officiële culturele sectoren. Ik zet hierbij in op een denken in termen van bondgenootschappen als het gaat over het begrijpen van een sociaal en cultureel sterk veranderende samenleving. In dat denken wordt de gevierde traditionele theaterregisseur bondgenoot van de hiphopper, en de regisseur en de hiphopper worden bondgenoten van de producenten van televisiedrama, en mogelijk zij op hun beurt weer van een wetenschappelijke onderzoeksgroep. Het gewicht van de maatschappelijke relevantie van mijn onderzoeksresultaten zal bepaald worden door het vermogen van betrokken actoren om met een andere blik te kijken naar verhoudingen tussen samenleving, overheden en gevestigde en minder gevestigde performatief culturele sectoren. Door deze andere blik op heden en toekomst worden de contouren zichtbaar van een verband tussen diverse performatieve kunst- en cultuursectoren die nu nog veelal als strikt gekaderd en gescheiden van elkaar beschouwd worden. 


\section{Doelgroepen}

De onderzoeksresultaten zijn interessant voor de gehele gevestigde theatersector en voor aangrenzende kunst- en cultuurdomeinen. Het gaat in dit onderzoek om het blootleggen van de onderlinge samenhang op het performatief spectrum, waardoor de uiteindelijke reikwijdte ervan veel groter is dan het gevestigde theater alleen. Gestart vanuit de theaterpraktijk raakt deze studie intermediale, interculturele en internationale professionaliteit in sectoren als de mode, de popmuziek, beeldende kunst, muziek, performancekunst, film, televisie en digitale media, community art, geesteswetenschappen en de overlappende grensgebieden tussen deze domeinen. Hierbij geldt dat de onderzoekresultaten niet alleen interessant kunnen zijn voor de diverse uitvoerende professionals in genoemde sectoren, maar evenzeer voor podiuminstituties, voor relevante kunstvakopleidingen, universitaire faculteiten in de betreffende kennisgebieden en betrokken beleidsorganisaties op landelijk en lokaal niveau.

\section{Activiteiten/producten}

Het is mijn ambitie geweest om met dit proefschrift uiteindelijk een breed publiek van vakgenoten, beleidsverantwoordelijken, theater-, performance- en mediaopleiders, geïnteresseerde leken en andere culturele stakeholders te bereiken middels een gedrukte handelseditie en eventueel een digitale uitgave via een reguliere uitgever. Het spreekt voor zich dat ik handel naar bevind van zaken waar het gaat om hiervan afgeleide producten als artikelen en eventuele interviews in tijdschriften of dag- en weekbladen. In het verleden, met name in de jaren van mijn onderzoek vanaf 2007 , heb ik verscheidene lezingen verzorgd in binnen- en buitenland over het onderwerp van mijn onderzoeksproject. Het is voorstelbaar dat ik na afronding van dit onderzoeksproject op dit ingeslagen pad verder ga en lezingen ga verzorgen over de strekking van mijn beweringen of specifieke onderdelen daarvan.

De concrete vertaling van de onderzoeksresultaten krijgt op dit moment al vorm in mijn lopende onderwijstaken op de Toneelacademie Maastricht en mijn advieswerk voor de domeincommissie podiumkunsten van de Raad voor Cultuur. Op de Toneelacademie verzorg ik lessen en begeleid ik werkgroepen op het gebied van dramaturgie, van theater-, performance- en mediageschiedenis van de twintigste eeuw en van mapping intermediality in performance. Bovendien draag ik als reflective practitioner mijn steentje bij op reguliere studiedagen en rond beleids- en curriculumontwikkeling op de Toneelacademie. Wat betreft mijn advieswerk voor de Raad voor Cultuur: in het voorjaar van 2014 trad ik toe tot de adviseursgroep en in datzelfde voorjaar kwam de publicatie De Cultuurverkenning. Ontwikkelingen en trends in het culturele leven in Nederland (Raad voor Cultuur, 2014) van de Raad uit als voorzet en start van de nieuwe cultuurnota voor de periode $2017-2020$. Ik ben actief 
betrokken bij de totstandkoming van het advies van de Raad aan de minister, in kleinere werkgroepen van de domeincommissie en tijdens grotere plenaire werkbijeenkomsten van de Raad. Ik tracht mijn onderzoeksresultaten zo concreet mogelijk vorm te geven door de manier waarop ik inhoudelijk bijdraag aan dit proces van totstandkoming van het raadsadvies.

\section{Innovatie}

Het innovatieve van mijn blik op het theatersysteem, op de werking van theaterinstituties, bestaat vooral uit het blootleggen van een nieuw verband tussen het groeiend aantal actoren op het performatief spectrum. Tot nu toe was de blikrichting van de meeste betrokken actoren voor een belangrijk deel gericht op het verleden: er werd hoofdzakelijk een theatertraditie vormgegeven, gebaseerd op een specifieke manier van werken (regisseur, acteursensemble, vormgevers, theatervoorstellingen, theaterpubliek), op een westers, canoniek toneelrepertoire en op een opvoeringstraditie in zalen met een ruimtelijke constitutie die zijn oorsprong heeft in de burgerlijke cultuurtraditie van de negentiende eeuw. Mijn onderzoeksresultaten laten zien dat veel van de huidige actoren deze traditionele setting achter zich hebben gelaten: veel gezelschappen produceren geheel andere voorstellingen dan hierboven genoemd, podia zijn al lang niet meer allemaal gevormd naar een model uit de negentiende eeuw, op hedendaagse theateropleidingen is minstens zoveel aandacht voor film, televisie, performance en digitale media als voor toneelteksten van Sophocles, Shakespeare, Vondel, Racine, Goethe, Ibsen en Tsjechov. De blikrichting is voor veel hedendaagse gezelschappen, podia en opleidingen daarmee meer contextueel en voor een deel meer voorwaarts gericht op een tijd die nog niet volledig doorzien wordt, op het nu en op een nabije toekomst. Het gaat bij de meest innovatieve actoren in hun werk om het bevragen van het huidige tijdgeest in het algemeen en de relatie tussen de canon en culturele context in het bijzonder. Veel huidige theater-, performance-, en mediakunstenaars doen vooral pogingen om te begrijpen wat er op ons af komt in een veranderende samenleving, in plaats van alleen representerend cultureel erfgoed door te geven op basis van vaak als vanzelfsprekend veronderstelde canonieke kwaliteit die lang niet voor iedereen meer zo vanzelfsprekend is. Het meest innovatief te noemen aan mijn onderzoek is echter het feit dat ik het theatersysteem in zijn geheel heb beschouwd vanuit een practice based uitgangspositie als docent-onderzoeker verbonden aan een Nederlandse theateropleiding. Anders dan veel van mijn wetenschappelijke collega's heb ik naast aan veranderende theateresthetiek en veranderende publieksvoorkeuren ook nadrukkelijk aandacht geschonken aan de volgens mij medeconstitutieve rol van theateropleidingen en van theaterbeleidspremissen. 
De onderzoeksresultaten laten zien dat de Nederlandse overheid staat voor een grote uitdaging. Als enige van de vier institutionele actoren in het theatersysteem blijft de overheid tot nu toe achter als het gaat om het aanpassen van de blikrichting en het formaliseren van een andere dan de gebruikelijke traditionele samenhang tussen samenleving, theatersector en overheid. Er zal beleidsmatige ruimte moeten komen voor het incorporeren in het landelijk kunst- en cultuurbeleid van een spectrale samenhang tussen theater-, performance- en mediasectoren. De signalen in de aanloop naar de nieuwe cultuurnotaperiode 2017 - 2020 zijn in beginsel hoopgevend. De huidige verantwoordelijke minister Jet Bussemaker en de Raad voor Cultuur tonen weliswaar oog te hebben voor een veranderende sociaal-maatschappelijke en culturele context, maar het Nederlandse politieke klimaat in 2015 maakt dat dit feit op zichzelf nog allerminst geruststellend is.

\section{Planning en realisatie}

Concrete marktkansen en kosten voor het valorisatietraject van deze onderzoeksresultaten zijn op dit moment nog moeilijk te formuleren. De succesvolle verdediging van dit proefschrift en de realisatie van een handelseditie zullen naar verwachting een bijdrage leveren aan het publiekelijk uitdragen van de innovatieve visie op de samenhang tussen theater-, performance- en mediasectoren, zoals ik die voorsta. De belangrijkste effecten hiervan zouden kunnen bestaan uit het incorporeren van deze samenhang in het Nederlandse kunst- en cultuurbeleid en in het Nederlandse kunstvakonderwijs. Kansen zijn er dan te definiëren daar waar bondgenootschappen tussen verschillende cultuuruitingen de plaats in gaan nemen van voormalige vijandelijke of concurrerende posities; het beeld van culturele bondgenootschappen zou op den duur culturele vijandbeelden kunnen gaan vervangen.

In de nieuwe constellatie op basis van de veranderde blikrichting zullen sommigen mogelijke risico's zien in bijvoorbeeld de tijdelijkheid van subsidies voor culturele proefopstellingen, samenwerkingen en artistieke onderzoeken, of in het waarschijnlijk onvermijdelijke krimpen van de segmenten traditioneel cultureel erfgoed op het gebied van theater. Het is goed om ons te realiseren dat daartegenover staat dat bepaalde delen van het performatief spectrum inhoudelijk wél op een interessante manier tot de beleids- en opleidingsdomeinen van de nieuwe culturele samenhang te rekenen zijn maar dat ze door hun publiek succes waarschijnlijk veel minder een beroep hoeven doen op publieke middelen dan bijvoorbeeld hun collega's van de traditionele gesubsidieerde toneelgezelschappen. Mijn inschatting is dat deze verschillen het komende decennium nog wel voor verwarring zullen zorgen, maar dat de substantiële inzichten over de onderlinge samenhang alleen maar zullen groeien. 


\section{Dankwoord}

In de afgelopen acht jaar heb ik met wisselende intensiteit gewerkt aan dit proefschrift, een coproductie van de Toneelacademie Maastricht, Zuyd Hogeschool, het Lectoraat Autonomie \& Openbaarheid in de Kunsten en de Universiteit Maastricht. $\mathrm{Nu}$ het project is afgerond, heb ik de behoefte om de mensen te bedanken die ieder op hun eigen manier een bijdrage hebben geleverd. Ten eerste dank ik mijn promotor Maaike Meijer en copromotor Peter Peters voor hun begrip en geduld. Met name voor hen moet mijn worsteling met de academische mores nu en dan een ware bezoeking zijn geweest. Toch bleven ze in onze soms weerbarstige werksessies in Maastricht inspirerende bijdragen leveren aan mijn denkproces. Waar ik me weleens liet meeslepen door 'visionaire vergezichten', zetten zij mij weer met mijn beide benen op de grond om ervoor te zorgen dat er een onderbouwd boekwerk kwam. Voorts dank ik alle informele lezers van ruw materiaal voor hun waardevolle commentaar, van wie hier met name collega's Arthur Sonnen, Frank Mineur, Ruth Benschop, Chiel Kattenbelt en Robin Nelson vernoemd dienen te worden.

Ik wil ook mijn dank uitspreken aan de mensen die mijn onderzoekstraject in de eerste plaats mogelijk hebben gemaakt. De altijd geïnteresseerde en meedenkende voormalig directeur van de Toneelacademie Maastricht, Leo Swinkels, die uitermate genereus is geweest met onderzoekstijd; het College van Bestuur van Zuyd Hogeschool, dat het onderzoeksproject voor een belangrijk deel heeft willen financieren. Ook de studenten van de Toneelacademie Maastricht wil ik bedanken. Zij hebben mij voortdurend scherp gehouden voor wat betreft zaken die er in de actuele theater-, performance-en mediawereld toe doen. Verder heb ik gedurende de dagelijkse opleidingspraktijk onnoembaar veel gehad aan de steun en feedback van mijn naaste collega's van het kernteam van de acteurs- en performersopleiding. Vanaf dag één van het onderzoeksproject waren dat Yvette Fijen, René Lobo, Woody Laurens, Rob Salden, Hans Münstermann en Peter Missotten, en meer recentelijk Ingrid Wender, Martin Verheesen en Bert Luppes. Zij leverden me de vriendelijke, stimulerende en intellectueel uitdagende omgeving die een dergelijke missie vereist. Voorts dank ik op de Toneelacademie Maastricht de stille krachten 'die er altijd zijn', Patricia de Kort, Debbie ten Berge, Betty Hover en Sophie de Loos, voor de kleine noodzakelijke dingen, de halve woorden en op goede momenten de goede vragen. 
Bij het uitvoeren van de casestudies kon ik niets zonder de welwillende medewerking van de betrokkenen. Veel dank ben ik dan ook verschuldigd aan Guy Cassiers, Erwin Jans, An-Marie Lambrechts, Arjen Klerkx, Jan van der Putten, Rodney Weterings, Madeleine Matzer, Theo van Dooremalen, Piet-Jan Dusee en nog veel anderen, werkzaam bij het Toneelhuis Antwerpen, de Verkadefabriek in 'sHertogenbosch en bij een organisatie als de Boekmanstichting.

Het eindtraject van het onderzoek had ik niet kunnen volbrengen zonder mijn belangrijkste meelezer in het finale redactieproces, Annemarie Rijkers, de scherpste taalslijpster die ik ken. Door haar leerde ik kritisch te worden op mijn eigen woorden.

Helpen en steunen bestaat voor een belangrijk deel uit inschatten waar, wanneer en hoeveel. Soms was hands-on hulp noodzakelijk, soms bleek het goed om me simpelweg met rust te laten. Mijn naasten, mijn vrouw Jet, onze kinderen Thijs en Janna, en mijn broers en vrienden hebben dat door de jaren heen in goede verhoudingen weten te doen. Ze wisten hoe belangrijk dit project voor me was. Mijn dank aan jullie allen is groter dan ik met een paar woorden kan uitdrukken.

Maastricht/Tilburg, juli 2015

Henk Havens 


\section{Curriculum vitae}

Henk Havens werd op 1 januari 1954 in Tilburg geboren. Na het behalen van het vwodiploma (1974) vervulde hij zijn militaire dienst (1974-1975) om vervolgens te gaan studeren aan de Sociale Academie Markendaal te Breda (1975-1979). Na deze studie was hij enige jaren actief in maatschappijkritische culturele organisaties (1977-1983) en als staflid werkzaam bij een resocialisatieproject voor daklozen en verslaafden in Tilburg (1983-1986). In de tweede helft van de jaren tachtig studeerde hij theaterwetenschap aan de Universiteit Utrecht (1984-1991). Tijdens deze studie, die hij afrondde met een masterscriptie over de overheidsbemoeienis met theaterdistributie, werkte hij als student-assistent aan de Universiteit Utrecht en als theaterrecensent voor de Brabantse regionale kranten (Brabant Pers). Vrijwel meteen na zijn afstuderen ging hij werken als dramaturgiedocent en afdelingscoördinator aan de Toneelacademie Maastricht.

Naast zijn docentschap heeft hij zich op de Toneelacademie eind jaren negentig beijverd voor de implementatie van de nieuwe studierichting tot uitvoerend theatraal performer, waarmee gestart werd in september 2000. Na het invoeren van het Bachelor-Mastersysteem in het hoger onderwijs zette hij zich samen met collega's Yvette Fijen, Frank Mineur en Leo Swinkels in om een lectoraat vorm te geven aan de kunstfaculteiten van Zuyd Hogeschool. Vanaf de start daarvan in 2002 was hij lid van de kenniskring van dit Lectoraat Nieuwe Theatraliteit, hij leidde er de onderzoeksgroep 'theater en technologie'. Dit laatste resulteerde onder meer in de bundel Theater \& technologie (2006), uitgegeven door het Theater Instituut Nederland in samenwerking met de Toneelacademie Maastricht. Toen het Lectoraat Nieuwe Theatraliteit na vier jaar voortgezet werd onder de naam Lectoraat Autonomie \& Openbaarheid in de Kunsten bleef hij daar tot in de zomer van 2012 als onderzoeker aan verbonden.

Naast zijn werk op de Toneelacademie heeft hij in de loop der tijd diverse nevenfuncties in de theaterpraktijk vervuld. Tussen 2001 en 2004 was hij lid van de dramaturgenstaf van Johan Simons bij ZTHollandia in Eindhoven; hij heeft een aantal malen zitting genomen in provinciale en gemeentelijke adviescommissies voor podiumkunstsubsidiëring; hij was bestuurslid van het klein theatergezelschap Drie Ons en van 2006 tot 2011 bestuursvoorzitter van danstheatergezelschap T.R.A.S.H. Vanaf 
het voorjaar van 2014 is hij een van de adviseurs van de domeincommissie podiumkunsten van de Raad voor Cultuur.

In 2007 werd hij lid van de internationale Workinggroup Intermediality in Theatre and Performance van de International Federation for Theatre Research (IFTR) en woonde in die hoedanigheid een reeks van werkgroepsessies bij tijdens vakcongressen in Montréal (2007), Avignon (2008), Lissabon (2009), München (2010) en Utrecht (2011). Voor een door deze werkgroep in 2010 bij de Amsterdam University Press uitgegeven bundel, Mapping Intermediality in Performance, leverde hij de bijdrage 'The Intermedial Performer prepares', over het hedendaags opleiden van theaterprofessionals. In 2008 leidde zijn fascinatie voor de relatie tussen het opleiden van theaterprofessionals en technologie tot de publicatie 'Zwischen Technolab und Bühnen-Rampe' in het Duitse vakblad Theater der Zeit/Double.

Vanaf de zomer van 2007 heeft hij parttime kunnen werken aan zijn proefschrift als een coproductie tussen de Toneelacademie Maastricht/Zuyd Hogeschool, het Lectoraat Autonomie \& openbaarheid in de kunsten en de Universiteit Maastricht. Henk Havens is gehuwd met Henriette Visser. Samen hebben zij twee kinderen. 